UNIVERSIDADE DE SÃO PAULO

FACULDADE DE FILOSOFIA, LETRAS E CIÊNCIAS HUMANAS

DEPARTAMENTO DE LETRAS MODERNAS

PROGRAMA DE PÓS-GRADUAÇÃo EM LÍNGUA, LITERATURA E CULTURA

ITALIANAS

FRANÇA HELENA AMANDIO BERTON

DISCORDÂNCIA E DESAPROVAÇÃO EM SALA DE AULA: UM ESTUDO SOBRE A (NÃO)UTILIZAÇÃ̃ DE ESTRATÉGIAS ATENUADORAS EM CONTEXTO BILÍNGUE ÍTALO-BRASILEIRO

DISSERTAÇÃO DE MESTRADO

(VERSÃO CORRIGIDA) 



\title{
DISCORDÂNCIA E DESAPROVAÇÃO EM SALA DE AULA: UM ESTUDO SOBRE A (NÃO)UTILIZAÇÃ̃O DE ESTRATÉGIAS ATENUADORAS EM CONTEXTO BILÍNGUE ÍTALO-BRASILEIRO
}

\author{
(VERSÃO CORRIGIDA)
}

Dissertação de mestrado apresentada ao Programa de Pós-Graduação em Língua, Literatura e Cultura Italianas do Departamento de Letras Modernas da Faculdade de Filosofia, Letras e Ciências Humanas, da Universidade de São Paulo, como parte dos requisitos necessários à obtenção do título de mestre.

Orientadora: Profa. Dra. Elisabetta A.R.M.C.Santoro

São Paulo 
Autorizo a reprodução e divulgação total ou parcial deste trabalho, por qualquer meio convencional ou eletrônico, para fins de estudo e pesquisa, desde que citada a fonte.

Catalogação na Publicação

Serviço de Biblioteca e Documentação

Faculdade de Filosofia, Letras e Ciências Humanas da Universidade de São Paulo

Berton, França
DISCORDÂNIA E DESAPROVAÇÃo EM SALA DE AULA: UM
ESTUDO SOBRE A (NÃO) UTILIZAÇÕo DE ESTRATÉGIAS
ATENUADORAS EM CONTEXTO BILINGUE ITALO-BRASILEIRO /
França Berton ; orientador Elisabetta Santoro. - São
Paulo, 2017.
253 f.
Dissertação (Mestrado) - Faculdade de Filosofia,
Letras e Ciências Humanas da Universidade de São
Paulo. Departamento de Letras Modernas. Área de
concentração: Lingua, Literatura e Cultura Italiana.
1. Pragmática linguistica, cross-cultural,
intercultural, interlinguistica. 2. Cortesia verbal,
Atenuação. 3. Discordância. 4. Desaprovação. 5.
Bilinguismo italiano - portugues brasileiro. I.
Santoro, Elisabetta, orient. II. Título.


BERTON, França. Discordância e desaprovação em sala de aula: um estudo sobre a (não) utilização de estratégias atenuadoras em contexto bilíngue ítalo-brasileiro. Dissertação (Mestrado) apresentada à Faculdade de Filosofia, Letras e Ciências Humanas da Universidade de São Paulo para obtenção do título de Mestre em Língua, Literatura e Cultura Italianas.

Aprovado em:

Banca Examinadora

Prof. Dr. Instituição

Julgamento Assinatura

Prof. Dr. Instituição

Julgamento Assinatura

Prof. Dr. Instituição

Julgamento Assinatura

Prof. Dr. Instituição

Julgamento Assinatura 

A Deus que me deu vida, força e oportunidade para realizar esta pesquisa. 



\section{AGRADECIMENTOS}

A Deus, por ter me concedido o dom da vida e por ter despertado em mim a vontade de aprender.

Aos meus pais, Dirce e André, meus primeiros professores, por terem cuidado de mim com tanta dedicação e por, sempre, terem me proporcionado tudo o que podiam. Sou, especialmente, grata pelos ensinamentos que contribuíram para o meu amadurecimento pessoal e para o meu crescimento intelectual.

À minha primeira professora do Jardim de Infância, Rosália, que talvez nem saiba a importância que teve na minha vida, mas que deixou registrado no meu coração seu afeto e amor por ensinar.

Ao professor Rubens, tão importante em minha vida, que esteve presente em todas as fases de desenvolvimento desta pesquisa, me incentivando e apoiando em todos os momentos, principalmente, nos momentos mais difíceis. Agradeço a oportunidade de compartilhar não somente as questões da profissão, mas também as reflexões sobre a vida.

À minha orientadora, professora Elisabetta Santoro, por ter me conduzido nesse caminho árduo da pesquisa. Agradeço as sugestões, críticas, correções, direcionamentos e dedicação durante todo esse percurso.

Aos professores Luiz Antônio da Silva e Maria Zulma Kulikowski por terem aceitado o convite para participarem da minha banca de qualificação e por terem feito sugestões e críticas valiosas para a concretização desta pesquisa.

À professora Mona Mohamad Hawi, pelo carinho, paciência, ensinamentos, sugestões e incentivos durante a pós-graduação.

Às professoras Ingrid e Lyris e aos alunos da Scuola Italiana Eugenio Montale que contribuíram com o corpus da pesquisa.

A todos os meus alunos e ex-alunos que são a razão do meu trabalho. Obrigada pelo respeito, pelo carinho, pela troca de ensinamentos e, principalmente, obrigada por me presentearem com a amizade de vocês ao longo dos anos.

A todos os amigos e colegas que, durante esse período de pesquisa, dividiram comigo as dúvidas, inseguranças, angústias, risadas e alegrias.

À Capes, pela concessão da bolsa de mestrado e pelo apoio financeiro para a realização desta pesquisa. 

"Quando um diplomata diz 'sim', quer dizer 'talvez'; quando diz 'talvez', quer dizer 'não';

e quando diz 'não', não é um diplomata.

Quando uma dama diz, 'não', quer dizer 'talvez'; quando diz 'talvez', quer dizer 'sim';

e quando diz 'sim', não é uma dama."

Voltaire (1694-1778) 



\section{RESUMO}

BERTON, França. Discordância e desaprovação em sala de aula: um estudo sobre a (não) utilização de estratégias atenuadoras em contexto bilíngue ítalo-brasileiro. 2017. $253 \mathrm{f}$. Dissertação (Mestrado) - Faculdade de Filosofia, Letras e Ciências Humanas, Universidade de São Paulo, São Paulo, 2017.

Nossa pesquisa visa a compreender como as relações pessoais se constroem por meio da linguagem. Para isso, consideramos o contexto social, cultural e interacional que, combinados de diferentes maneiras, moldam os pensamentos, as falas e as atitudes de cada indivíduo. Intentamos por meio da análise de interações autênticas explorar e evidenciar aspectos pragmáticos presentes no português brasileiro e no italiano que constituem e influenciam o fazer discursivo dos falantes em sala de aula. A partir da análise dos atos de fala discordância e desaprovação realizados por falantes bilíngues de italiano e português brasileiro em contexto escolar de uma escola bilíngue ítalo-brasileira no Brasil, a pesquisa evidencia (i) os componentes pragmáticos das duas línguas relacionados à cortesia verbal e, mais especificamente, ao uso de estratégias atenuadoras; (ii) se e em que medida foram realizadas estratégias atenuadoras na produção desses atos de fala por crianças bilíngues, em contexto ítalo-brasileiro, durante a interação em sala de aula e quais são os efeitos da sua (não) utilização; (iii) em que medida existem analogias e diferenças na utilização de procedimentos atenuadores em italiano e português. A coleta de dados foi realizada por meio de videogravações das aulas, de uma entrevista preliminar com as professoras e de um questionário para os alunos. A partir da análise dos dados, verificamos que as discordâncias em língua portuguesa apresentavam um número maior de procedimentos atenuadores em relação àquelas em língua italiana. Notamos que a utilização de procedimentos atenuadores nos atos de discordância em português objetivava a prevenção de conflitos interacionais e nas relações pessoais, logo, a atenuação relacionava-se à cortesia verbal em sala de aula. Nas discordâncias em língua italiana, verificamos que o uso de procedimentos atenuadores objetivava, além da prevenção, a reparação da ameaça à imagem do interlocutor e, algumas vezes, exercia a função de auto proteger o falante. Desse modo, a atenuação nem sempre estava relacionada à cortesia verbal. Além disso, nos atos de discordância em língua italiana observamos uma menor utilização de procedimentos atenuadores em relação as discordâncias produzidas em língua portuguesa. A ausência de atenuadores pode estar relacionada a uma tendência da língua italiana em realizar as discordâncias de forma imediata e direta, em sala de aula. A análise dos dados de desaprovação revelou um equilíbrio entre presença e ausência de estratégias atenuadoras nos atos realizados em ambas as línguas. A presença de táticas atenuadoras está relacionada à cortesia verbal, em que o ato intrinsecamente ameaçador da face (intrinsic Face-Threatening Act - intrinsic FTA) da desaprovação era suavizado, tentando evitar conflito na relação. Observou-se assim que, quando a desaprovação era feita de forma atenuada podia ser interpretada com um pedido e, quando era expressa sem o uso de atenuadores, aproximava-se de uma ordem.

Palavras-chave: Pragmática; Atenuação; Discordância; Desaprovação; Bilinguismo italianoportuguês brasileiro. 



\begin{abstract}
BERTON, França. Disagreement and disapproval in the classroom: a study on the (non) use of attenuating strategies in Italian-Brazilian bilingual context. 2017. $253 \mathrm{f}$. Dissertação (Mestrado) - Faculdade de Filosofia, Letras e Ciências Humanas, Universidade de São Paulo, São Paulo, 2017.
\end{abstract}

Our research aims to understand how personal relationships are constructed through language. Therefore, we consider the social, cultural and interactional context that, combined in different ways, shapes the thoughts, speeches and attitudes of each individual. We have tried to explore and present some pragmatic aspects in the Brazilian Portuguese language and in the Italian language that constitute and influence the discursive making of the speakers in the classroom. Based on the analysis of disagreement and disapproval speech acts performed by bilingual speakers of Italian and Brazilian Portuguese in a school context of an ItalianBrazilian bilingual school in Brazil, the research has shown (i) the pragmatic components of Italian and Brazilian Portuguese related to verbal politeness and, more specifically, the usage of attenuating strategies in speech acts of disagreement and disapproval in the classroom; (ii) If and to which extent there was the use of attenuating strategies in the production of these speech acts by bilingual children, Italian-Portuguese Brazilians, during their interaction in the classroom and which are the effects of their (non) use; (iii) To which extent it was possible to identify analogies and differences in the use of attenuating procedures in Italian and Brazilian language. Data collection was done through video recordings of classes, a preliminary interview with the teachers and a questionnaire for the students. From the analysis of the data, we verified that the disagreements in the Portuguese language have presented more attenuation procedures related to the disagreements in the Italian language. We have observed that the use of attenuating procedures in the acts of disagreements in Brazilian Portuguese aimed at the prevention of interactional conflicts in personal relations, so the attenuation was related to verbal politeness in the classroom. In the disagreements in the Italian language, we have noted that the use of attenuating procedures had not only the intention of prevention, but also to repair the threat to the image of the interlocutor and sometimes exercised the function of self-protecting the speaker. Thus, attenuation was not always related to verbal politeness. In addition, in acts of disagreement in Italian language, we have observed a greater absence of attenuating procedures in relation to the disagreements produced in Brazilian Portuguese. The absence of mitigators may be related to a possible tendency of the Italian language in making disagreements immediately and directly in the classroom. The analysis of the disapproval data has revealed a balance between the presence and the absence of attenuating strategies in the acts performed in both languages. The presence of attenuating tactics was related to verbal courtesy, in which the intrinsic FTA (intrinsic Face-Threatening Act) of disapproval was softened, trying to avoid conflict in the relationship. Thus, it was observed that when the disapproval was attenuated it could have been interpreted as a request, while, when it was expressed without the use of attenuators, it was approaching an order.

Keywords: Pragmatics; Politeness; Disagreement; Disapproval; Italian-Brazilian Bilingualism. 



\begin{abstract}
BERTON, França. Disaccordo e disapprovazione in classe: uno studio sul (non) uso di strategie di mitigazione in contesto bilingue italiano-portoghese brasiliano. 2017. $253 \mathrm{f}$. Dissertação (Mestrado) - Faculdade de Filosofia, Letras e Ciências Humanas, Universidade de São Paulo, São Paulo, 2017.
\end{abstract}

L'obiettivo della nostra ricerca è comprendere in che modo le relazioni personali vengono costruite attraverso il linguaggio. Consideriamo, pertanto, il contesto sociale, culturale e interazionale che, combinati in modi diversi, modellano i pensieri, le parole e gli atteggiamenti di ogni individuo. Attraverso l'analisi di interazioni autentiche, abbiamo cercato di identificare aspetti pragmatici presenti in portoghese brasiliano e italiano che costituiscono e influenzano il discorso dei parlanti in una classe. A partire dall'analisi degli atti linguistici del disaccordo e della disapprovazione realizzati da parlanti bilingui di italiano e portoghese brasiliano nel contesto scolastico di una scuola bilingue ítalo-brasiliana in Brasile, la ricerca mette in evidenza (i) le componenti pragmatiche dell'italiano e del portoghese brasiliano relative alla cortesia verbale e, in particolare, all'uso in classe di strategie di mitigazione nel disaccordo e nella disapprovazione; (ii) se e in che misura si constata l'uso di strategie di mitigazione nella produzione di questi atti linguistici da parte di bambini bilingui, parlanti di italiano e portoghese brasiliano, durante l'interazione in classe e quali sono gli effetti della loro (non) utilizzazione; (iii) in che misura si osservano analogie e differenze nell'uso di strategie di mitigazione in portoghese e in italiano. La raccolta dei dati è stata effettuata per mezzo della videoregistrazione di lezioni, di un colloquio preliminare con gli insegnanti e di un questionario compilato dagli studenti. L'analisi dei dati ci ha permesso di verificare che gli atti del disaccordo in portoghese presentano un maggior numero di procedure di mitigazione rispetto a quelli in italiano. Si è osservato inoltre che l'utilizzo di procedure di mitigazione in atti di dissenso in portoghese aveva come obiettivo prevenire i conflitti interazionali e personali, mostrandosi quindi legata alla cortesia verbale in classe. Negli atti di disaccordo in italiano, si è invece notato che l'uso di procedure di mitigazione, oltre a presentare la funzione di prevenzione, presentava anche la funzione di riparazione della minaccia all'immagine dell'interlocutore e, a volte, aveva anche la funzione di autoproteggere il parlante. I dati mostrano che l'attenuazione non è sempre legata alla cortesia verbale. Per di più, negli atti di disaccordo in italiano si è constatata un'assenza più significativa di procedure di mitigazione in comparazione agli atti di disaccordo prodotti in portoghese. L'assenza di attenuatori può essere correlazionata a una tendenza della lingua italiana nei confronti della realizzazione in modo immediato e diretto di disaccordi in classe. L'analisi dei dati della disapprovazione ha rivelato equilibrio tra presenza e assenza di strategie di mitigazione negli atti effettuati in entrambe le lingue. La presenza di tattiche attenuative è legata alla cortesia verbale: l'atto intrinsecamente "minaccioso per la faccia" (intrinsic Face-Threatening Act-intrinsic FTA) della disapprovazione è stato mitigato, cercando in tal modo di evitare il conflitto. Si è così osservato che quando la disapprovazione era attenuata si sarebbe potuta interpretare come una richiesta, mentre quando era espressa senza l'uso di attenuatori si avvicinava a un ordine.

Parole chiave: Pragmatica; Attenuazione; Disaccordo; Disapprovazione; Bilinguismo italobrasiliano. 



\section{LISTA DE FIGURAS}

Figura 1 - Grade Curricular do Ensino Fundamental I da Scuola Italiana Eugenio Montale 90

\section{LISTA DE GRÁFICOS}

Gráfico 1 - Aula de Português 116

Gráfico 2 - Aula de Italiano 118

\section{LISTA DE QUADROS}

Quadro 1 - Características do ato de desaprovação ........................................................84

Quadro 2 - Características do ato de discordância ................................................................85

Quadro 3 - Divisão Educacional Italiana _....................................................................91

Quadro 4 - Divisão Educacional Brasileira ...........................................................................91

Quadro 5 - Dados pessoais dos informantes- parte 1 ..................................................................95

Quadro 6 - Dados pessoais dos informantes- parte 2 .................................................95

Quadro 7 - Normas de transcrição utilizadas pelo Projeto NURC ..................................100

Quadro 8 - Táticas atenuadoras utilizadas nos atos de discordância e desaprovação por crianças bilíngues, falantes de italiano e português brasileiro e suas professoras, durante a interação em sala de aula 



\section{LISTA DE ABREVIATURAS E SIGLAS}

AD

ALE

ARG

BRA

D

DP

ESP

FFA

FRA

FRAGMENTO DIS-IT

FRAGMENTO DIS-PT

FRAGMENTO DES-IT

FRAGMENTO DES-PT

FTA

ITA

L1

L2

LE

NURC

$\mathbf{P}$

$\mathbf{R}$
Análise do Discurso

Nacionalidade alemã

Nacionalidade argentina

Nacionalidade brasileira

Distância Social (Social Distance)

Discurso Pedagógico

Nacionalidade espanhola

Ato valorizador da face (Face Flattering Act)

Nacionalidade francesa

Fragmento de Discordância em Italiano

Fragmento de Discordância em Português

Fragmento de Desaprovação em Italiano

Fragmento de Desaprovação em Português

Ato Ameaçador da Face (Face Threatening Act)

Nacionalidade italiana

Língua Materna

Segunda Língua

Língua Estrangeira

Norma Urbana Culta

Poder Relativo (Relative Power)

Nível de Imposição (Absolut Ranking of Imposition) 



\section{SUMÁRIO}

INTRODUÇÃO ........................................................................................................................25

1. A LINGUAGEM SOB A PERSPECTIVA DA PRAGMÁTICA ......................................33

1.1 PRAGMÁTICA: LINGUÍSTICA, CROSS-CULTURAL, INTERCULTURAL E

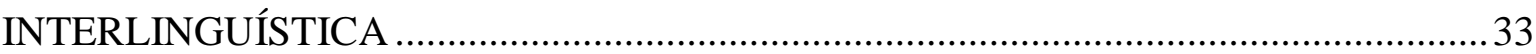

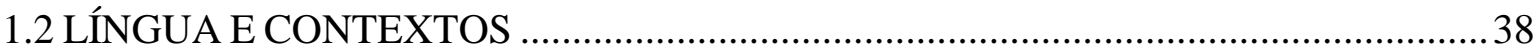

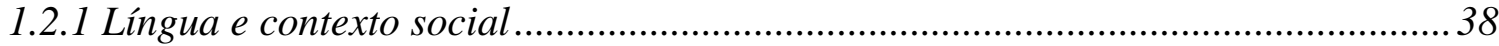

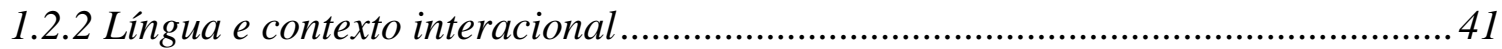

1.2.2.1 Língua e contexto interacional: sala de aula ...................................................... 45

1.2.2.2 Língua e contexto interacional: falantes bilingues ............................................ 50

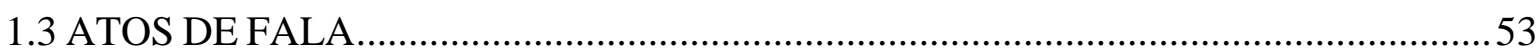

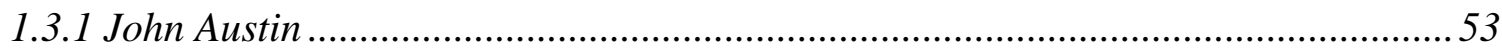

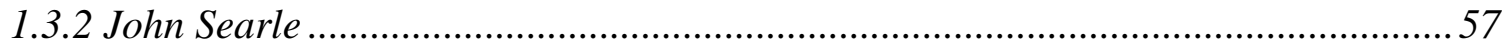

1.3.3 Princípio de cooperação: máximas conversacionais e implicaturas ....................... 60

1.3.4 Pressuposições semânticas e pragmáticas ................................................................ 63

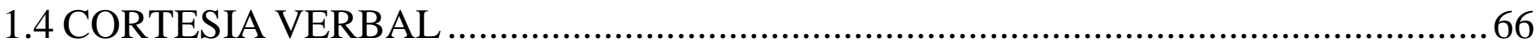

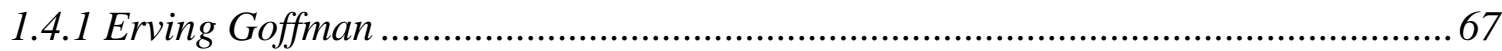

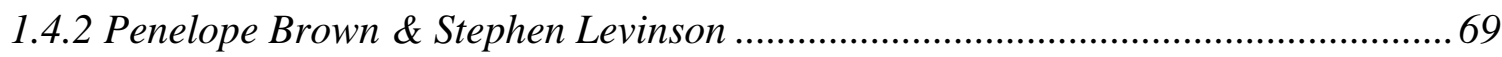

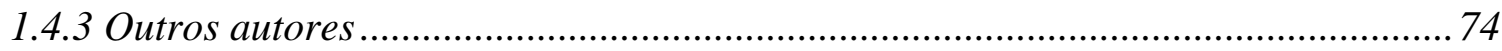

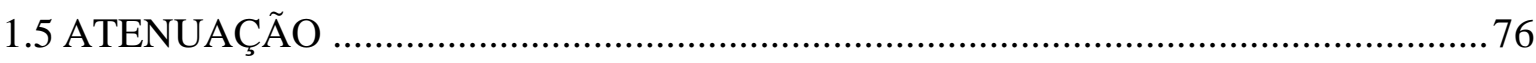

1.6 DISCORDÂNCIA E DESAPROVAÇÃO: CARACTERIZAÇÃO ...............................8 82

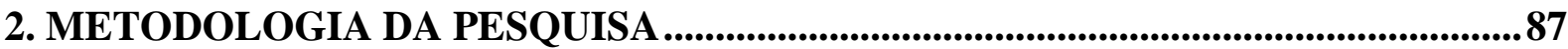

2.1 PESQUISA QUALITATIVA: ABORDAGEM ETNOGRÁFICA E ESTUDO DE CASO

2.2 CONTEXTO EDUCACIONAL DA PESQUISA: SCUOLA ITALIANA EUGENIO

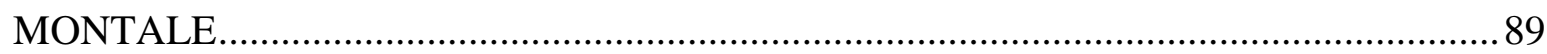

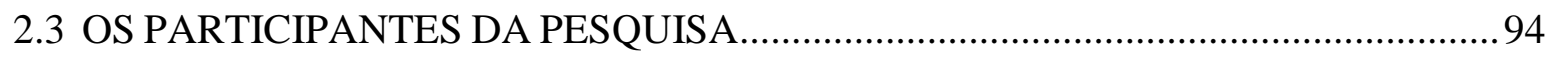

2.4 PROCEDIMENTOS E INSTRUMENTOS UTILIZADOS NA COLETA DE DADOS 96

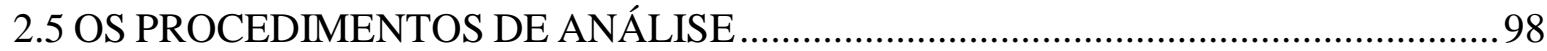

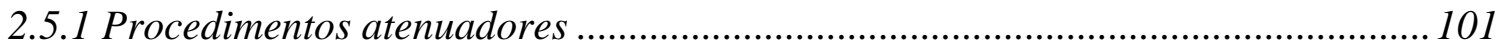




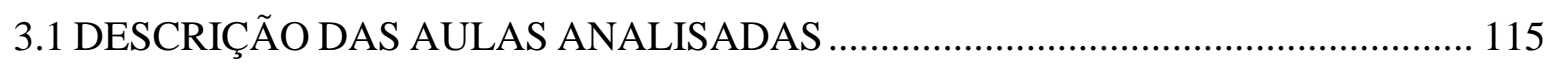

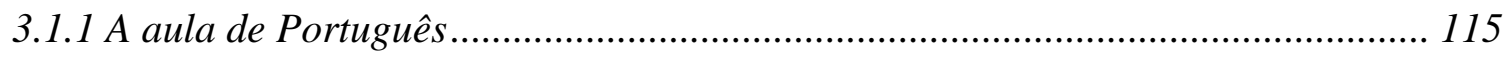

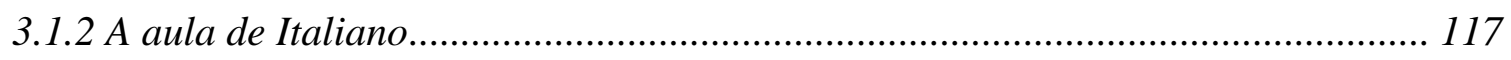

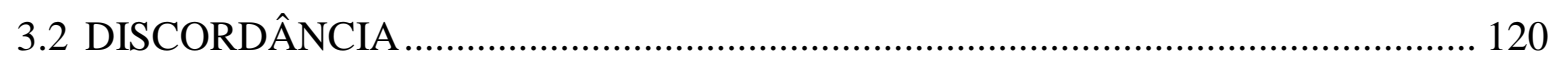

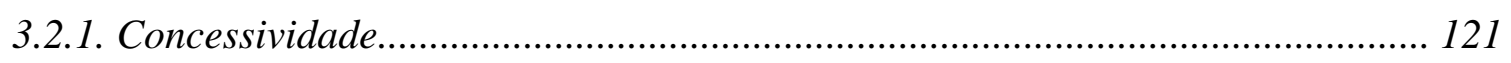

3.2.2 Partículas discursivas, expressões de controle e de contato com o interlocutor 135

3.2.3 Modalização dos tempos verbais .......................................................................... 141

3.2.4 Elementos prosódicos; formas de tratamento, formas apelativas convencionalizadas e marcadores discursivos modais de objetivação .....

3.2.5 Construções que limitam ou restringem e partículas e construções justificadoras do dizer.

3.2.6 Verbos, construções verbais e partículas discursivas com valor modal;

modificadores externos e estruturas sintáticas condicionais, concessivas ou temporais

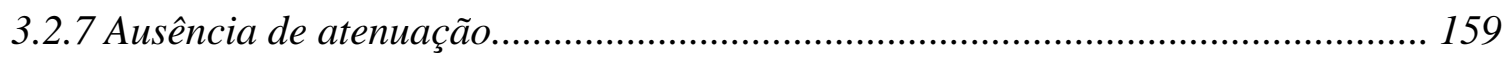

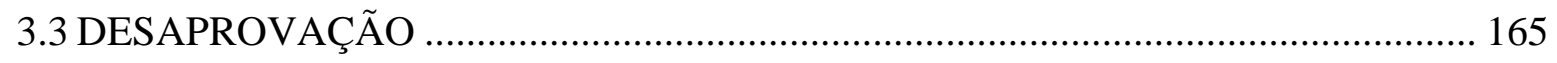

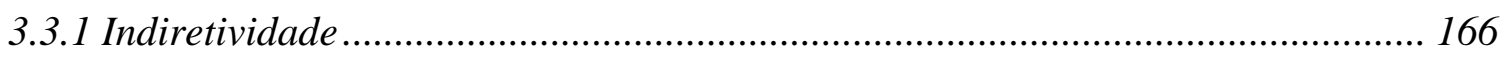

3.3.2 Partículas discursivas e expressões de controle e de contato com o interlocutor

3.3.3 Formas de tratamento e formas apelativas convencionalizadas ........................ 182

3.3.4 Modificadores externos: quantificadores minimizadores................................... 184

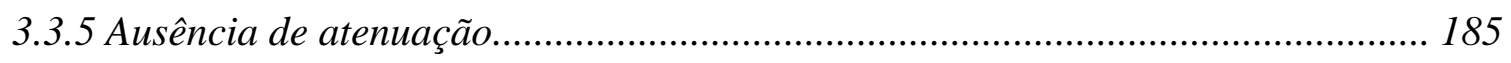

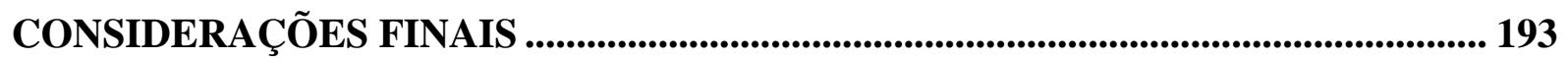

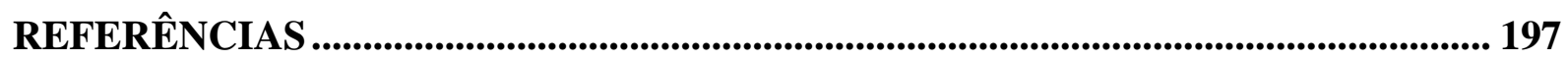

ANEXO A- MINUTAGEM DA AULA DE PORTUGUÊS ............................................... 205

ANEXO B- MINUTAGEM DA AULA DE ITALIANO .................................................. 209

ANEXO C- TRANSCRIÇÃO LIVRE DA AULA DE PORTUGUÊS .............................. 213

ANEXO D- TRANSCRIÇÃO LIVRE DA AULA DE ITALIANO.................................. 229

ANEXO E - QUESTIONÁRIO UTILIZADO PARA A COLETA DE DADOS........... 251

ANEXO F- TERMO DE CONSENTIMENTO LIVRE E ESCLARECIDO .................. 253 


\section{INTRODUÇÃO}

Esta pesquisa foi motivada, em primeiro lugar, pela curiosidade e pelo desejo de entender como as relações pessoais se constroem por meio da linguagem. Investigar o funcionamento da linguagem e sua construção nas relações entre falantes, contexto social, cultural e interacional não é tarefa fácil, porque é necessário considerar uma série de aspectos que, combinados de diferentes maneiras, moldam os pensamentos, as falas e as atitudes de cada indivíduo. Por isso, não pretendemos, em poucas páginas, esgotar um assunto tão complexo; o que tentaremos é, por meio da análise de algumas interações autênticas, explorar e evidenciar alguns aspectos presentes em cada cultura e em cada sociedade, que constituem e influenciam o fazer discursivo dos falantes.

Para realizar nossa investigação, optamos por uma abordagem pragmática dos fenômenos, por considerar a Pragmática uma teoria abrangente que dialoga com diversas áreas do saber. Além disso, como a pesquisa visa a investigar a construção das relações pessoais por meio da linguagem e como o modo de se relacionar varia culturalmente, achamos que seria profícuo comparar duas culturas, a fim de evidenciar possíveis semelhanças e diferenças no modo em que os falantes se relacionam entre si e produzem atos de fala. Assim, por vivermos no Brasil, escolhemos observar a sociedade brasileira de língua portuguesa e, por sermos especialistas em língua italiana, optamos por observar e comparar essas duas línguas próximas.

Devido à grande variedade dos usos da linguagem, fizemos um recorte teórico e optamos por selecionar e observar alguns atos de fala (tendo como pressuposto a visão pragmática de língua como ação) em italiano e português brasileiro de forma que, posteriormente, pudéssemos realizar uma comparação. Novas dúvidas surgiram: quais atos selecionar? Em qual contexto coletar? Atos de fala produzidos por quais falantes?

Para que fosse possível realizar uma comparação entre as duas culturas, sabíamos que os participantes da pesquisa deveriam ser falantes nativos de português brasileiro e de italiano. No entanto, não seria possível realizar, nesse momento, parte da pesquisa na Itália. A leitura de um artigo sobre uma pesquisa realizada em contexto escolar bilíngue no Canadá, com falantes de língua inglesa e língua francesa, nos deu a inspiração para realizarmos nossa pesquisa em um contexto escolar bilíngue ítalo-brasileiro. O fato de já ter desenvolvido uma pesquisa de iniciação científica sobre o ensino-aprendizagem de italiano para crianças foi um fator determinante para a escolha dos participantes da pesquisa. A faixa etária dessas crianças 
foi escolhida com base em critérios que serão explicitados no item 1.2.2.2 Língua e contexto interacional: falantes bilíngues. Assim, como na cidade de São Paulo existe apenas uma escola italiana na qual os alunos são italianos e brasileiros que se comunicam em língua italiana e portuguesa, decidimos analisar o contexto dessa escola.

$\mathrm{O}$ artigo mencionado acima, que inspirou parcialmente a escolha do contexto de nossa pesquisa, foi o de Merrill Swain (2005) e se baseia na hipótese de que a produção (output) é fundamental no processo de aprendizagem de uma língua não materna. Segundo tal hipótese, o ato de produzir língua (falando ou escrevendo) constitui parte essencial do processo de aprendizagem de uma segunda língua (L2) ${ }^{1}$ e não é apenas o resultado final. Swain, ancorada na sua experiência e nas pesquisas de outros autores, afirma que os alunos que são estimulados a reconstruir um texto (oral ou escrito) em L2 aprendem mais do que aqueles que se envolvem somente em atividades de compreensão e recepção de informações. As operações de codificação, o grau de análise e a profundidade do processamento mental na reelaboração da ideia em L2 contribuem para integrar e conectar elementos que estavam vagamente relacionados entre si durante o processo de compreensão. No entanto, para Swain, o sentido de reconstruir ou de "negociar o significado" precisa ser estendido para além do sentido usual de simplesmente transmitir uma mensagem gramaticalmente correta em L2, é necessário também que a linguagem seja sociolinguisticamente adequada, isto é, que a produção em L2 seja correta do ponto de vista gramatical e adequada do ponto de vista do contexto de uso.

Desse modo, Swain, sem utilizar a palavra Pragmática, acenava para a sua importância durante o processo de aprendizagem de L2, pois para a Pragmática o contexto molda a linguagem e quanto maior for o conhecimento e o domínio da linguagem, maior será a capacidade do falante de compreender e agir no contexto. Assim, o foco principal da nossa pesquisa é analisar, através da interação oral, como os falantes utilizam a língua em sala de aula, seja língua materna, segunda língua ou língua estrangeira. Por isso, embora nosso objetivo não seja o de analisar o processo de aprendizagem e aquisição de línguas, nossa pesquisa poderá oferecer contribuições significativas para suscitar reflexões a esse respeito.

Após termos escolhido o tema da investigação, os participantes e o contexto da pesquisa, faltava delimitar ainda quais atos de fala seriam observados para a comparação entre as duas línguas e culturas. Decidimos que seria melhor não determinar a priori quais atos de

\footnotetext{
${ }^{1}$ Segunda língua (L2) é a língua não materna, ou seja, é a língua que se aprende depois da primeira.
} 
fala estudar, mas discutir e estabelecer primeiro como e o que gravar. Foi realizada, portanto, a gravação em áudio e vídeo de uma aula de português e de uma aula de italiano ocorridas na Scuola Italiana Eugenio Montale e só depois verificou-se quais atos de fala se faziam presentes e qual o número de ocorrências de cada um. Chegamos assim, a dois tipos de atos: discordância e desaprovação. A partir da teoria dos atos de fala de Austin (1990 [1962]) e Searle (2009 [1969]), do conceito de face de Goffman (2011[1967]) e da teoria da cortesia de Brown \& Levinson (1987 [1978]), tentamos entender quais eram as características constitutivas desses atos e quais seus efeitos nas relações pessoais entre os falantes dentro do contexto específico de sala de aula.

Sobre o conceito de cortesia linguística, Mariottini (2007, p. 09) afirma que a utilização desse termo abrange todas aquelas estruturas recorrentes na língua escrita e falada que manifestam um comportamento comunicativo cooperativo e respeitoso. Percebemos, assim, que a cortesia é um princípio fundamental de equilíbrio que rege as relações entre os interlocutores durante uma troca verbal, principalmente, em atos que podem colocar em risco a imagem dos falantes, como a discordância e a desaprovação.

A cortesia verbal é, para Brown \& Levinson (1987[1978]), um princípio universal presente em todas as culturas. O objetivo de Brown e Levinson de formular um conjunto de conceitos "éticos", culturalmente aplicável, para qualquer sociedade, era ambicioso. Os conceitos éticos analíticos foram desenhados a partir de um conjunto universal, definido fora de uma perspectiva cultural particular e usado para comparar sistemas comportamentais e linguísticos em diferentes grupos culturais. Nesse sentido, o princípio da universalidade defendido pelos estudiosos esteve no centro de muitas polêmicas. As críticas a esse modelo se baseiam principalmente no fato de que cada cultura possui seus próprios sistemas comportamentais e linguísticos e, assim, a ideia é a de que a cortesia se configura de modo diferente em cada sociedade, pois existem estratégias que cada cultura desenvolve para evitar que as relações pessoais entrem em conflito durante a interação.

Um dos princípios que fazem parte da cortesia é a atenuação, definida por Briz (2013, p. 292) como uma atividade argumentativa e estratégica de minimização da força ilocucionária e do papel dos participantes na enunciação. Dito de outra maneira, a atenuação constitui-se de procedimentos verbais e não-verbais utilizados pelos falantes com a intenção de minimizar a força de um enunciado e consequentemente de tentar preservar o equilíbrio das relações pessoais durante a interação verbal. 
Desse modo, nossa pesquisa propõe, como objetivo geral, investigar, sob o enfoque da Pragmática, o funcionamento da linguagem por meio da construção das relações pessoais em contexto de sala de aula.

Os objetivos específicos podem ser identificados por meio das seguintes questões que norteiam o trabalho:

(i) Quais são os componentes pragmáticos do italiano e do português brasileiro relacionados à cortesia verbal e, mais especificamente, ao uso de estratégias atenuadoras nos atos de fala discordância e desaprovação em sala de aula;

(ii) Se e em que medida é possível identificar a utilização de estratégias atenuadoras na produção desses atos de fala por crianças bilíngues, italiano-português brasileiro, durante a interação em sala de aula e quais são os efeitos da sua (não) utilização;

(iii) Em que medida é possível identificar analogias e diferenças na utilização dos procedimentos atenuadores em italiano e português.

Após a delimitação dos objetivos que norteariam nossa pesquisa, empreendemos uma investigação sobre o atual estado da arte, isto é, sobre as pesquisas já realizadas nessa área até o presente momento. Assim, determinamos como palavras-chave de nossa pesquisa os seguintes termos: atenuação, sala de aula, discordância, desaprovação e bilinguismo.

Em âmbito local, realizamos uma sondagem no banco de teses e dissertações da USP (disponível em: <www.teses.usp.br>) e constatamos que até o $1^{\circ}$ semestre de 2017 não havia nenhuma publicação sobre a atenuação nos atos de fala "discordância" e "desaprovação" em contexto escolar, nem trabalhos sobre cortesia verbal realizados com crianças bilíngues falantes de italiano e português brasileiro. Os únicos trabalhos encontrados nessa base de dados que se aproximavam do nosso tema foram, em ordem de publicação, o de Anaisy Sanches Teixeira (2012) com o título: Um mot... un mot simplement: procedimentos de atenuação em francês e português, trata-se de uma dissertação de mestrado, que apresenta a análise de estratégias de polidez negativa presentes em entrevistas televisivas realizadas por falantes de francês e de português brasileiro. O outro trabalho que encontramos foi a dissertação de mestrado de Ramiro Caggiano Blanco (2016), intitulada Atenuação pragmática e problemas de intercompreensão um estudo intercultural entre paulistanos e cordobeses, que realiza uma comparação dos empregos de procedimentos atenuadores em atos diretivos e respostas não preferidas por estudantes universitários das cidades de São Paulo (Brasil) e Córdoba (Argentina). A coleta dos dados ocorreu por meio de questionários e focou situações de interação em ambiente de trabalho e da faculdade. Notamos que esses trabalhos analisam 
separadamente duas culturas, no primeiro caso, a francesa e a brasileira e, no segundo caso, a brasileira e a argentina e, em seguida, as comparam. Nossa pesquisa, no entanto, além de confrontar duas culturas, a brasileira e a italiana, pretende também observar a interação entre os falantes nativos bilíngues de cada uma dessas culturas em ambiente escolar.

Em âmbito nacional, realizamos a busca na biblioteca digital brasileira de teses e dissertações (disponível em: <www.bdtd.ibict.br>), utilizando as mesmas palavras-chave e encontramos mais dois trabalhos, ambos sobre discordância. O primeiro deles foi a dissertação de mestrado de Letícia Ludwig Loder (2006), como o título Investindo no conflito: a correção pelo outro construindo discordâncias agravadas, defendida na UFRGS, na qual a autora, por meio da análise da conversação, analisa a relação entre correção e discordância em interações cotidianas. $O$ outro trabalho foi a dissertação de mestrado de Roberta Fernandes Pacheco (2008), defendida na PUC-RJ, sob o título de $O$ ato de discordância em contexto argumentativo do espanhol. A pesquisa analisa sequências de discordância produzidas num contexto de debate televisivo em espanhol e o objetivo é verificar como se realiza a discordância em contexto argumentativo. Embora haja pesquisas sobre atenuação e, ao menos parcialmente, sobre os atos de fala que serão objetos desta pesquisa nenhum dos trabalhos trata do que pretendemos abordar, isto é, a atenuação em contexto de sala de aula por meio de atos de discordância e desaprovação realizados por alunos bilíngues falantes de português brasileiro e italiano.

A pesquisa justifica-se porque ainda é escasso o número de pesquisas em âmbito nacional sobre a atenuação, principalmente, nos atos de fala de discordância e desaprovação. Além disso, parecem não existir, até o momento, pesquisas que enfoquem a interação entre crianças bilingues falantes de português brasileiro e italiano no Brasil.

As razões de nossa pesquisa, realizada a partir da análise da produção oral de crianças bilíngues, falantes de italiano e português brasileiro, durante a interação em sala de aula, são: oferecer uma contribuição para os estudos sobre a produção de linguagem, em língua materna (L1), em segunda língua (L2) e em língua estrangeira (LE), bem como, chamar à atenção para a componente pragmática presente na linguagem, que é um meio de agir no mundo, organizando, comentando e regulando o agir e as interações humanas, e na língua, parte constitutiva da identidade dos falantes. Portanto, para que o ensino e aprendizagem de língua seja bem sucedido, com possibilidades concretas, para o falante, de ação dentro de um determinado contexto cultural, a componente pragmática não pode ser ignorada. 
Nesse sentido, é necessário considerar o processo de ensino-aprendizagem de línguas como um processo que deve ser direcionado para a formação de um cidadão crítico, capaz de fazer uso da língua-alvo para atuar na sociedade em que vive. A aprendizagem de línguas deve, de fato, contribuir para a formação do indivíduo como um todo, desempenhando o papel de ampliar a sua capacidade de entender o mundo em que vive, sua cultura e as diferenças em relação aos aspectos da cultura de outra língua.

Além disso, nossa pesquisa visa a contribuir para os estudos da Pragmática, da Cortesia verbal e da Atenuação. Diferentemente dos "erros" gramaticais que um falante estrangeiro pode cometer durante a interação com um falante nativo de qualquer língua, na qual o estrangeiro pode contar com a compreensão do nativo, quando se comete um "erro" de inadequação pragmática, o falante estrangeiro recebe imediatamente uma avaliação negativa. O "erro" pragmático do falante estrangeiro é, muitas vezes, entendido pelo falante nativo como um desrespeito às normas de cortesia da cultura do falante nativo e isso é diretamente relacionado a algum traço negativo da personalidade ou da capacidade do falante de se relacionar com os outros. Nossa pesquisa propõe uma reflexão sobre essas questões a partir dos atos de fala da discordância e da desaprovação, tão pouco estudados até o momento.

A presente dissertação organiza-se da seguinte forma:

No primeiro capítulo, é abordada a questão da linguagem sob a perspectiva da Pragmática, é introduzida a noção de língua como ação (AUSTIN, 1990 [1962]) e são tecidas algumas considerações sobre a Pragmática linguística, cross-cultural e intercultural. Em seguida, é explorada a noção de contexto em Pragmática, estabelecendo relações entre língua e contexto social e língua e contexto interacional. Na sequência, essas relações são caracterizadas dentro das especificidades do nosso contexto de pesquisa, isto é, dentro do contexto interacional com falantes bilíngues, na sala de aula, de uma escola bilíngue ítalobrasileira no Brasil. Logo após, adentrando o universo pragmático, apresenta-se a teoria dos atos de fala (AUSTIN, 1990 [1962]) e (SEARLE, 2009 [1969]), relacionando-a com o princípio de cooperação: máximas conversacionais e implicaturas (GRICE, 1975) e com a distinção entre pressuposições semânticas (FREGE, 1892; RUSSELL, 1905; STRAWSON, 1950) e pragmáticas (AUSTIN, 1990 [1962]; GRICE, 1975; STALNAKER, 2002). Com o objetivo de investigar a construção das relações pessoais, foi escolhida a teoria da cortesia verbal, com os conceitos de face (GOFFMAN, 2011 [1967]) e com o modelo de Brown e Levinson (1987 [1978]), e foi incluída ainda a contribuição de outros autores como Fraser \& Nolen (1981); Blum-Kulka (1992); Bravo (2005). Dentro da teoria da cortesia verbal, 
lançamos nosso olhar para a atenuação e seus efeitos no discurso e nas relações pessoais Caffi (1999); Briz (1995, 1998, 2003); Briz \& Albelda (2013) e finalizamos com a caracterização, com base nos conceitos apresentados, dos atos de fala que serão analisados no nosso corpus de pesquisa: discordância e desaprovação.

No segundo capítulo, apresentamos a metodologia de pesquisa; retomamos algumas características do contexto e dos participantes da pesquisa, indicamos os instrumentos usados na coleta de dados e explicamos o procedimento de análise.

No terceiro capítulo, desenvolvemos a análise dos dados, enfatizando as estratégias atenuadoras utilizadas pelos falantes durante a interação em sala de aula, na produção dos atos de fala de discordância e desaprovação, realizados em português brasileiro e italiano. Apresentamos também a comparação das estratégias atenuadoras utilizadas em ambas as línguas.

Por fim, tecemos as considerações finais e apresentamos as referências. Com a inclusão dos anexos, buscamos oferecer acesso aos materiais utilizados na pesquisa e à totalidade dos dados gravados e transcritos. 


\section{A LINGUAGEM SOB A PERSPECTIVA DA PRAGMÁTICA}

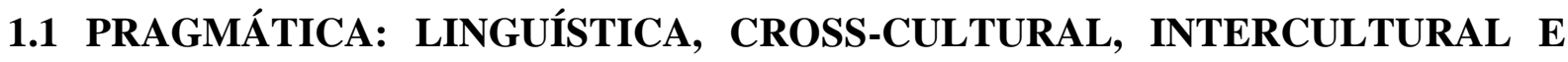 INTERLINGUÍSTICA}

O termo Pragmática foi introduzido, pela primeira vez, pelo filósofo americano Charles Morris, em 1938, na obra intitulada Foundations of the Theory of Signs. Nessa obra, o autor identificou e definiu três diferentes ramos de estudo dentro da Semiótica: a Sintaxe, a Semântica e a Pragmática. Segundo o autor, a Sintaxe busca explicar por que algumas frases, em uma determinada língua, são bem estruturadas e aceitas gramaticalmente e outras não, sendo consideradas agramaticais. Já a Semântica estuda os significados das palavras e suas possíveis aplicações dentro de uma frase para dar ou não sentido a ela. A Pragmática, por sua vez, é definida como o estudo da relação entre as palavras e os usuários. Trata-se de uma primeira caracterização, que não leva em consideração vários aspectos, mas é uma definição importante, já que destaca a relação existente entre as palavras e os sujeitos, isto é, quem utiliza as palavras.

Rajagopalan (2014), discorrendo sobre a amplitude do termo Pragmática nos dias de hoje, afirma que "[...] a pragmática, longe de ser um mero componente da tríade semiótica [...] (sintaxe, semântica e pragmática) constitui-se em uma nova perspectiva, uma nova forma de vislumbrar a linguagem como um todo" (p. 28). Escreve ainda: "Em outras palavras, ela deixou de ser um simples componente de análise linguística para ocupar um lugar bem mais abrangente e ambicioso" (p. 29). Mas qual seria a perspectiva da Pragmática?

Olhando brevemente para a história da linguagem, percebemos que, desde Aristóteles, ela era vista como uma atividade meramente referencial, isto é, prevalecia a ideia de que a linguagem era apenas instrumento para descrever a realidade. Desse modo, os enunciados eram avaliados logicamente e classificados como verdadeiros ou falsos, conforme sua comprovação no mundo real. Essa concepção de linguagem se perpetuou por vários anos e um dos questionamentos que transformou essa visão apareceu por volta de 1955, quando um filósofo chamado John Austin proferiu uma série de doze conferências na Universidade de Harvard, que, em 1962, seriam publicadas sobre o título de How to do things with words. Trata-se de uma publicação póstuma, na qual o filósofo colocava em evidência, com reflexões pioneiras, a dimensão "acional" da linguagem, isto é, o fato de que com a linguagem os 
indivíduos não descrevem somente a realidade, mas agem sobre ela. Essa noção do agir por meio da linguagem é o principal pilar dos estudos da Pragmática.

Assim, a perspectiva pragmática vê a linguagem como uma forma de ação, isto é, de realizar coisas e agir sobre o mundo modificando a realidade. Quando falamos, o significado se constrói por meio das palavras que escolhemos e também por meio do contexto no qual o enunciado é proferido. De fato, a noção de contexto também é central nos estudos pragmáticos e inclui o lugar da enunciação, o momento histórico e específico da comunicação e os falantes envolvidos na troca comunicativa. Portanto, para compreender um enunciado, é necessário considerar todos os fatores que o envolvem e que lhe dão sentido.

Borges Neto (2014) dá o seguinte exemplo retirado de um contexto real. Uma nota publicada na coluna "painel" do jornal Folha de São Paulo em 1991 anunciava "Corre sigilosamente num cartório de Brasília um processo de divórcio". Borges Neto afirma que, ao ter levado essa notícia para a sala de aula, a interpretação foi unânime: Rosane e Fernando Collor estão se divorciando. $\mathrm{O}$ autor chama a atenção para o fato de que essa informação não estava contida no texto e que ela resulta, em parte, de um conjunto de informações veiculadas na época pela mídia. Tanto que anos mais tarde, em 2011, o autor levou a mesma notícia para a sala de aula, sem revelar o contexto de sua publicação e nenhum aluno relacionou-a ao divórcio de Collor e Rosane demonstrando assim, a importância do contexto para a compreensão de um determinado enunciado.

Armengaud (2006 [1985]) afirma que a Pragmática se apresenta como tentativa de responder a perguntas como:

Que fazemos quando falamos? Que dizemos exatamente quando falamos? Por que perguntamos a nosso vizinho de mesa se ele pode nos passar o sal, quando é flagrante e manifesto que ele pode? Quem fala, e a quem? Quem fala e com quem? Quem você acha que sou para me falar desse modo? Precisamos saber o quê para que uma ou outra frase deixe de ser ambígua? O que é uma promessa? Como alguém pode dizer uma coisa completamente diferente daquilo que queria dizer? Podemos confiar no sentido literal de uma frase? (p. 09)

A Pragmática não rejeita a importância da gramática, da semântica e da sintaxe na compreensão e na produção de um enunciado por parte do falante, mas vai além. Para a Pragmática, a descrição lógica dos enunciados, como faziam os adeptos da visão referencial da linguagem, muitas vezes, não é suficiente para explicá-los. Caffi (2009) dá o seguinte 
exemplo, ao encontrarmos uma placa na rua de "proibido estacionar", não podemos afirmar que a proibição é verdadeira ou falsa, nesse caso, mais adequado seria classificar o enunciado como válido ou inválido de acordo com o contexto no qual a placa está inserida. Dessa forma, uma frase gramatical e sensata, do ponto de vista sintático e semântico, pode ser usada em um modo apropriado ou inapropriado dependendo do contexto.

Na visão da Pragmática, o falante é dotado, não apenas de competência linguística e comunicativa $^{2}$, mas também da competência do "saber fazer". E saber "fazer" com a linguagem é se apropriar da situação e do contexto para agir de modo eficaz, produzindo resultados e efeitos na realidade. Por isso, a Pragmática vai além, porque supera a ideia de uma competência gramatical ou linguística a favor de uma competência geral, que englobe um saber estar no mundo. É por saber estar no mundo que o falante pode interpretar o seu papel de membro social competente.

Portanto, o modelo de sujeito para a Pragmática é, segundo Caffi (2009), não o de falantes que interiorizaram um sistema de regras e que sabem produzir frases sintaticamente bem estruturadas e semanticamente corretas, mas de

\begin{abstract}
membros competentes de um grupo social, capazes de produzir comportamentos adequados a um certo tipo de situação, a uma atividade destinada a um certo tipo de objetivo e, que, sabem dar sentido às práticas comunicativas que possuem uma determinada forma. Os sujeitos da Pragmática, como eu a concebo, possuem uma identidade plural, não somente linguística, ligada aos papéis de tempos em tempos atualizados; são sujeitos em contínua construção; não somente, são sujeitos que se constroem através dos seus próprios discursos. ${ }^{3}$

[membri competenti di un gruppo sociale, in grado di produrre dei comportamenti adeguati ad un certo tipo di situazione, a un certo tipo di attività finalizzata a scopi, e che sanno dare un senso a delle pratiche comunicative che hanno una certa forma. I soggetti della pragmatica come io la concepisco hanno un'identità plurima, non soltanto linguistica, legata ai ruoli di volta in volta attualizzati; sono dei soggetti in continua costruzione; non solo, sono dei soggetti che si costruiscono proprio attraverso i loro discorsi.]. ( p. 55)
\end{abstract}

Assim sendo, para a autora, um falante competente é aquele que sabe produzir comportamentos adequados em determinados contextos sociais. São sujeitos em contínua construção, que se constroem por meio da linguagem. Em outras palavras, os sujeitos, por

\footnotetext{
${ }^{2}$ Segundo Hymes (1979), a competência comunicativa refere-se, primeiramente, a saber quando falar e quando calar, o que falar, a quem, quando, onde e de que forma.

${ }^{3}$ Exceto onde indicado, todas as traduções desta dissertação são de minha autoria.
} 
meio da linguagem, arquitetam e modificam a realidade, as relações sociais e suas próprias identidades.

Escandell Vidal (1996) resume o objeto de estudo da Pragmática nas seguintes palavras:

Entende-se por Pragmática o estudo dos princípios que regulam o uso da linguagem na comunicação, ou seja, as condições que determinam tanto o uso de um determinado enunciado concreto por parte de um falante concreto em uma situação comunicativa concreta, como sua interpretação por parte do destinatário.

[Se entiende por pragmática el studio de los principios que regulan el uso del language en la comunicación, es decir, las condiciones que determinan tanto el empleo de un enunciado concreto por parte de un hablante concreto en una situación comunicativa concreta, como su interpretación por parte del destinatario. $]$ ( p.13-14)

Para Escandell Vidal, a Pragmática ocupa-se do estudo dos princípios que regulam o uso da linguagem na comunicação, isso abrange tanto as condições que determinam o emprego de um enunciado por parte de um falante em uma situação comunicativa quanto sua interpretação por parte do destinatário. Logo, estudar a linguagem sob a perspectiva da Pragmática é olhar, ao mesmo tempo, para os aspectos internos da língua, como a semântica e a sintaxe e, para os aspectos externos ao sistema, como fatos históricos, políticos, sociológicos, ligados à cultura de cada comunidade linguística.

Caffi (2009) afirma ainda que cada cultura faz um recorte diferente da realidade e elabora assim, sua rede de saberes compartilhados dentro daquela comunidade. Por consequência, a comunidade linguística estabelece uma série de estratégias argumentativas e de etapas inferenciais que serão percorridas com a finalidade de reconstruir o significado completo de um determinado enunciado. A autora resume essa ideia afirmando que

A Pragmática lida com a língua em situação. Lida com os usos da língua em contextos; é o estudo dos usos linguísticos contextualizados. Usos que seguem estratégias gerenciadas intersubjetivamente. Por isso, a Pragmática não lida somente com uma língua e sua gramática, mas também com sua cultura. O saber usar uma língua está inserido no saber conduzir os procedimentos de ações reconhecidas, reconhecíveis e compartilhadas por um determinado grupo social. Saber usar uma língua significa saber estar no mundo.

[La pragmatica si occupa della lingua in situazione. Si occupa degli usi della lingua in contesti; è lo studio degli usi linguistici contestualizzati.Usi che seguono strategie gestite intersoggettivamente. Per questo la pragmatica non si occupa soltanto di una lingua e della sua grammatica, ma anche di 
una cultura. Il saper usare una lingua è inscritto nel saper condurre le procedure di azione riconosciute, riconoscibili, e condivise da un dato gruppo sociale. Saper usare una língua vuol dire saper stare al mondo.] ( p. 19)

Assim, os sujeitos são vistos como membros competentes de um grupo social e que sabem produzir comportamentos adequados a um determinado tipo de situação e a um determinado tipo de atividade, visando a alcançar um determinado objetivo. Por esse motivo, as análises pragmáticas ancoram-se em realidades de tipo cultural e social. O objetivo não é entender somente um enunciado, mas quais os efeitos nos comportamentos dos falantes após terem usado um determinado enunciado dentro de um contexto específico. Portanto, o que interessa é entender porque o falante disse o que disse e por que um determinado comportamento linguístico possui determinados efeitos no discurso e na relação entre os interlocutores.

Nesse sentido, nossa pesquisa visa a observar como crianças bilíngues utilizam a língua italiana e a língua portuguesa na interação em sala de aula com seus colegas de classe e com suas respectivas professoras. Almejamos, em um primeiro momento, verificar se esses falantes possuem competência pragmática em ambas as línguas e, a partir disso, observar como as relações pessoais se constroem naquele contexto.

Estudar a construção das relações pessoais e sociais por meio das interações verbais entre sujeitos membros de uma sociedade cultural poderia assim nos permitir entender o funcionamento daquela cultura. É esse o objetivo geral da Pragmática, que estuda todos os fenômenos linguísticos que ligam a língua ao contexto da vida real. Desse modo, a Pragmática, por constituir-se de uma área de estudos tão extensa e complexa, é dividida em subáreas de estudos, como a:

- Pragmática linguística que se ocupa, por exemplo, do estudo dos atos de fala, do princípio de cooperação, das implicaturas, da cortesia, do princípio da interação dentro de uma determinada cultura;

- Pragmática cross-cultural propõe a comparação entre duas ou mais línguas e culturas;

- Pragmática intercultural focaliza a interação entre nativos e não nativos em uma determinada língua e cultura. 
- Pragmática interlinguística estuda o ensino e a aprendizagem da pragmática em aprendizes de línguas estrangeiras.

Assim sendo, nossa pesquisa é centrada na perspectiva pragmática, porque concebe a língua como ação. Insere-se no âmbito da Pragmática linguística, porque analisa a língua a partir do contexto da enunciação, dos conceitos de atos de fala, do princípio de cooperação, das implicaturas e da cortesia. Ao mesmo tempo, configura-se também numa pesquisa das esferas da Pragmática cross-cultural e intercultural, visto que propomos a comparação entre duas culturas, a brasileira e a italiana, focalizando as interações entre falantes bilíngues ou quase bilíngues de italiano e português brasileiro. E, por fim, relaciona-se, também à Pragmática interlinguística, pois, além de serem nossos informantes, são também aprendizes de uma língua não materna. Nesse sentido, nossas observações podem ajudar a pensar o ensino e a aprendizagem da componente pragmática em sala de aula.

\subsection{LÍNGUA E CONTEXTOS}

\subsubsection{Língua e contexto social}

Em 1929, acredita-se que Bakhtin, sob o pseudônimo de V. N. Volochínov, escreveu a obra Marxismo e Filosofia da Linguagem, a qual tem como pressuposto as relações entre linguagem e sociedade. $\mathrm{O}$ autor caracteriza e analisa criticamente duas correntes do pensamento filosófico-linguístico: o subjetivismo idealista e objetivismo abstrato para propor uma teoria da enunciação e um novo olhar sobre a natureza da linguagem.

De acordo com Bakhtin, a corrente teórica que ele chamou de subjetivismo idealista interessava-se pelo ato da fala, de criação individual. $\mathrm{O}$ autor sintetiza as características dessa visão da seguinte forma: a língua é uma atividade, um processo criativo ininterrupto de construção, que se materializa sob a forma de atos individuais de fala; as leis da criação linguística são essencialmente as leis da psicologia individual; a criação linguística é uma criação significativa, análoga à criação artística; a língua, como produto acabado, é vista como estável, como um instrumento pronto para ser usado (BAKHTIN, 2002, p. 72-73). Como um dos mais notórios representantes dessa tendência, Bakhtin cita Wilhelm Humboldt. Em outras palavras, nessa perspectiva o contexto social não teria uma significação direta na 
construção do pensamento e da enunciação, pois, para os teóricos do subjetivismo idealista, o pensamento originava-se de dentro para fora, isto é, o pensamento era expressão do interior para o exterior. A língua era apenas um instrumento utilizado para expressar o que já estava no interior do sujeito, portanto, criação subjetiva individual.

Em oposição a essa visão de língua, estavam os teóricos adeptos ao que Bakhtin denominou objetivismo abstrato, para os quais o centro organizador de todos os fatos da língua é o sistema linguístico (sistema de formas fonéticas, gramaticais e lexicais da língua). São esses traços que garantem a unicidade de uma dada língua e sua compreensão. Do ponto de vista do indivíduo, as leis linguísticas são arbitrárias, isto é, privadas de uma justificação natural ou ideológica (por exemplo, artística). Se a língua, como conjunto de formas, é independente de todo impulso criador e de toda ação individual, logo é produto de uma criação coletiva, um fenômeno social. Bakhtin enumera as seguintes características dessa perspectiva: a língua é um sistema estável, imutável de formas linguísticas submetidas a uma norma fornecida; as leis da língua são essencialmente leis linguísticas específicas, que estabelecem ligações entre os signos linguísticos no interior de um sistema fechado, são objetivas e não subjetivas; as ligações linguísticas específicas nada tem a ver com valores ideológicos (artísticos, cognitivos, ou outros), ou seja, entre a palavra e seu sentido não existe vínculo natural e compreensível para a consciência; os atos individuais de fala constituem simples refrações ou variações fortuitas ou mesmo deformações das formas normativas (BAKHTIN, 2002, p. 82-83).

Um dos representantes mais eminentes do objetivismo abstrato é Saussure. Para Bakhtin, como também para Saussure, a língua é um fato social, cuja existência se fundamenta nas necessidades da comunicação, mas, ao contrário de Saussure, que faz da língua um objeto abstrato ideal, homogêneo e rejeita suas manifestações individuais (a fala), Bakhtin, por sua vez, valoriza justamente a fala (a enunciação).

De acordo com Bakhtin, a fala está indissoluvelmente ligada às condições de comunicação e a enunciação é a unidade de base da língua. A enunciação faz parte de um processo de comunicação ininterrupto, é um elemento do diálogo, portanto, é uma criação coletiva, um fenômeno social e não existe fora de um contexto social. A situação dá forma à enunciação que, por sua vez, veicula, elabora e transmite ideias, logo a enunciação é ideológica. Para Bakhtin todo signo é ideológico, a ideologia é reflexo das estruturas sociais, assim toda modificação da ideologia encadeia uma modificação na língua. 
A concepção de língua de Bakhtin, além de ideológica é também dialógica (diálogo), uma vez que há sempre um interlocutor, ao menos potencial, e um locutor que pensa e se exprime para um auditório bem definido. Sendo o signo e a enunciação de natureza social, em que medida a linguagem determina a consciência, a atividade mental? Em que medida a ideologia determina a linguagem? Para o filósofo, o pensamento forma-se a partir do exterior, ou seja, do contexto social. É o contexto social que molda os sentimentos do indivíduo e esses sentimentos, por sua vez, vão moldar a sua enunciação, que é a expressão do modo de se relacionar com o mundo exterior, tanto que Bakhtin afirma: "a situação social mais imediata e o meio social mais amplo determinam completamente e, por assim dizer, a partir do seu próprio interior, a estrutura da enunciação" ( 2002, p. 113).

Em outras palavras, o pensamento não existe sem a língua e a língua não existe sem contexto social, ou seja, a existência de uma está condicionada à existência da outra, são indissociáveis. Nas palavras do autor "pode-se dizer que não é tanto a expressão que se adapta ao nosso mundo interior, mas o nosso mundo interior que se adapta às possibilidades de nossa expressão, aos seus caminhos e orientações possíveis" (BAKHTIN, 2002, p. 118).

Resumindo, o contexto exterior gera língua, que gera pensamento, que gera expressão que se materializa no mundo exterior. A expressão, por sua vez, age novamente no interior do sujeito provocando reflexão e diálogo com o meio no qual está inserido. É um ciclo. Dessa forma, o estudo da linguagem não pode estar apartado do contexto que o produz.

Colaborando para o desenvolvimento dessa perspectiva, nasce a Análise do Discurso (AD), a qual coloca como elemento fundamental a relação entre linguagem e contexto de produção. Orlandi (1987) afirma que a AD abre um campo de questões no interior da linguística, relacionando o conhecimento da linguagem ao conhecimento das formações sociais. Segundo a autora, a AD considera a exterioridade como constitutiva dos processos e das condições de produção da linguagem e define discurso não como transmissão de informação, mas como

efeito de sentidos entre interlocutores, enquanto parte do funcionamento social geral. Dessa forma, os interlocutores, a situação, o contexto histórico social, as condições de produção, constituem o sentido da sequência verbal produzida. Quando se diz algo, alguém o diz de algum lugar da sociedade para outro alguém também de algum lugar da sociedade e isso faz parte da significação. ( p. 26) 
Além disso, para a autora "[...] a AD tem relações importantes com a Pragmática, a Enunciação e a Argumentação, mas inclui, nessas relações, a consideração necessária do ideológico, ao asseverar que não há discurso sem sujeito nem sujeito sem ideologia" (ORLANDI, 1987, p. 13).

Podemos acrescentar que, se não há discurso sem sujeito, nem sujeito sem ideologia, também não há contexto sem sujeito, pois como afirma Van Dijk:

os contextos não são um tipo de condição objetiva ou de causa direta, mas antes construtos (inter) subjetivos concebidos passo a passo e atualizados na interação pelos participantes enquanto membros de grupos e comunidades. Se os contextos fossem condições ou restrições sociais objetivas, todas as pessoas que estão na mesma situação social falariam do mesmo modo. (2012, p. 11)

Dessa forma, os contextos são construtos dos participantes, ou seja, durante uma interação não é somente o discurso que é produzido e influenciado pelo contexto, mas também o contexto interacional é produzido e influenciado pelo discurso. Como veremos a seguir, o contexto apresenta algumas características fixas e algumas variáveis.

\subsubsection{Língua e contexto interacional}

Corroborando a ideia de que, durante a interação, o discurso é construído simultaneamente pelos participantes da conversação, Kerbrat-Orecchioni (2006) afirma que o exercício da fala implica uma interação em que os diferentes participantes exercem uns sobre os outros uma rede de influências mútuas, assim, escreve a autora "na interação face a face, o discurso é inteiramente 'coproduzido', é o produto de um 'trabalho colaborativo' incessante" (p.11). Portanto a interação é dinâmica e pode ser modificada durante seu processo de produção.

A autora faz uma distinção entre interações verbais (conversações) e interações não verbais (circulação, dança, esportes coletivos etc). Dentro das interações verbais, KerbratOrecchioni enumera, na mesma obra (2006, p. 13) diferentes tipos, tais como: conversações familiares, entrevistas, debates, reuniões de trabalho etc. Para a caracterização de cada uma dessas trocas comunicativas, salienta que é importante levar em consideração alguns aspectos 
do contexto, como a natureza do lugar (quadro espaço-temporal); o objetivo da interação, o número e a natureza dos participantes; seus estatutos e respectivos papéis.

A seguir, a estudiosa descreve o lugar como o espaço físico onde se desenvolve a interação (lugar aberto ou fechado, público ou privado, apartamento, loja, restaurante, sala de aula etc.) e o quadro temporal (adequação do discurso ao momento). O objetivo da interação pode ser dividido em dois: objetivo global da interação (o exemplo utilizado é o de uma consulta médica) e o objetivo mais pontual expresso pelos diferentes atos de fala ${ }^{4}$ realizados ao longo do encontro. Com relação aos participantes, são considerados: (a) o número (conversação face a face, a três ou mais); (b) as características individuais (idade, sexo, profissão, posição social, traços de caráter etc); (c) suas relações mútuas (grau de conhecimento, natureza do laço social - familiar ou profissional - com ou sem hierarquia) e afetivas (simpatia, antipatia, amizade, amor etc.) Com relação aos papéis participativos na interação, Kerbrat-Orecchioni salienta que toda troca comunicativa implica a existência de um falante e de um (ou mais) ouvinte(s) e que, no decorrer da conversação, se alternam os papéis interlocutivos (o falante se torna ouvinte e vice-versa), porém, os papéis interacionais são relativamente estáveis, porque estão diretamente ligados ao tipo de interação em curso. Exemplos de papéis interacionais são: médico/paciente; professor/aluno; vendedor/cliente etc. Kerbrat-Orecchioni faz uma distinção entre papel interacional e estatuto social. O estatuto social é parte constituinte do falante engajado na interação (ex: professor, jornalista, juíz etc) e o papel interacional é o papel ("script") que o falante assume na interação (ex: entrevistador). A autora ressalta que, muitas vezes, o papel interacional pode coincidir com o estatuto social (ex: médico, professor etc.) e que alguns papéis não correspondem a nenhum estatuto particular (ex: os papéis de paciente ou de "participantes numa conversação").

Em relação ao quadro espaço-temporal, nossa pesquisa foi realizada em uma sala de aula de uma escola da rede particular de ensino, localizada na cidade de São Paulo. Os papéis interacionais são caracterizados pela relação aluno-professor e o objetivo global da interação entre professor e alunos é o ensino-aprendizagem. No caso específico das aulas analisadas, o objetivo é desenvolver a habilidade de compreensão de texto em língua portuguesa e em língua italiana. Quanto ao número e a natureza dos participantes, o nosso corpus é composto por 13 crianças, com idades entre 9 e 12 anos, das quais 4 são italianas e 9 brasileiras, todas

\footnotetext{
${ }^{4}$ Essa noção será explorada e desenvolvida mais adiante, na sessão 1.3.
} 
falantes bilíngues de português e italiano. Participaram da pesquisa também as respectivas professoras de italiano e de português, ambas brasileiras.

Outro fator presente na interação verbal, que evidencia a relação entre língua e contexto interacional, é a dêixis. O termo é usado para evidenciar uma variedade de traços gramaticais ligados diretamente às circunstâncias da enunciação, como o uso dos demonstrativos, pronomes da primeira e da segunda pessoa, tempo verbal, advérbios específicos de tempo e lugar como o "aqui" e o "agora".

Segundo Levinson (2007)

a dêixis diz respeito às maneiras pelas quais as línguas codificam ou gramaticalizam traços do contexto da enunciação ou do evento de fala ${ }^{5}$ e, portanto, também diz respeito a maneiras pelas quais a interpretação das enunciações depende da análise desse contexto de enunciação. Assim, o pronome "isto, este (a)" não nomeia nem se refere a nenhuma entidade específica em todas as ocasiões de uso; antes é uma variável ou marcador de lugar para alguma entidade específica dada pelo contexto (por exemplo, por meio de um gesto). (2007, p. 65)

Para ilustrar a importância da informação dêitica na interpretação das enunciações, Levinson usa como exemplo, a situação de encontrar uma garrafa no mar e, dentro dela, uma mensagem que diz: "Encontre-me aqui, dentro de uma semana com uma vara mais ou menos desse tamanho". Nesse instante, não sabemos quem encontrar, onde encontrar, quando encontrar ou que tamanho de vara levar, ou seja, se não conhecermos as informações do contexto dificilmente conseguiremos interpretar de forma eficaz a mensagem. Escreve o autor "as enunciações das línguas naturais, portanto, estão diretamente 'ancoradas' em aspectos do contexto" (LEVINSON, 2007, p. 67). E ainda, com relação à construção de significado, escreve: "o objetivo da Pragmática (pelo menos em parte) é determinar, dada uma sentença enunciada num contexto, como aquele contexto contribui para especificar qual proposição a sentença expressa nessa ocasião de enunciação" (LEVINSON, 2007, p. 71) ou, em outras palavras, como o contexto contribui para a construção e a seleção de sentido de uma determinada sentença.

Dessa forma, segundo Levinson, a dêixis diz respeito à codificação de muitos aspectos diferentes das circunstâncias que cercam a enunciação, dentro do próprio enunciado. $\mathrm{O}$ autor enumera as seguintes categorias da dêixis: pessoa, lugar e tempo.

\footnotetext{
${ }^{5}$ Grifos do autor.
} 
A dêixis de pessoa diz respeito à codificação do papel dos participantes no acontecimento discursivo em que a enunciação em questão é proferida: a categorização primeira pessoa é a gramaticalização da referência do falante a si mesmo, a segunda pessoa a codificação da referência do falante a um ou mais destinatários e a terceira pessoa a codificação da referência a pessoas e entidades que não são falantes nem destinatários da enunciação em questão. Os papéis dos participantes são codificados na linguagem, principalmente, por meio do uso de pronomes.

A dêixis de lugar concerne à codificação das localizações espaciais relativamente à localização dos participantes no acontecimento discursivo. Essas localizações espaciais são codificadas nos demonstrativos (este, esse, esta, essa, isso, aquele, aquela, aquilo etc.) e nos advérbios dêiticos de lugar (aqui, lá etc).

A dêixis de tempo refere-se à codificação de pontos e extensões temporais relativamente ao tempo em que uma enunciação foi pronunciada (ou uma mensagem foi escrita). Levinson afirma que, assim como uma dêixis de lugar codifica localizações espaciais em coordenadas ancoradas no lugar da enunciação, a dêixis de tempo codifica os tempos em coordenadas ancoradas no tempo da enunciação. A dêixis de tempo é comumente gramaticalizada nos advérbios dêiticos de tempo, como: agora, então, ontem, neste ano etc. e nos tempos verbais.

A essas categorias, Lyons (1968, 1977a) e Fillmore (1971b, 1975) acrescentaram a dêixis de discurso e a dêixis social. A dêixis de discurso é a codificação da referência feita a porções do discurso em andamento no qual se localiza a enunciação. São exemplos os usos dos demonstrativos "esse", "aquele" quando retomam uma parte do discurso já enunciado para poder dar continuidade a ele. A dêixis social refere-se à codificação de distinções sociais relativas aos papéis dos participantes, particularmente, a aspectos da relação social entre falante e o(s) destinatário(s) ou entre falante e algum referente. São exemplos o uso de pronomes (que podem indicar formalidade, em algumas línguas), formas de interpelação ou vocativo e expressões de tratamento.

Fillmore (1971b) faz uma distinção entre os usos dos dêiticos e divide-os em: gestual e simbólico. Termos usados de uma maneira dêitica gestual só podem ser interpretados com referência a um monitoramento áudio-visual-tátil ou mais em geral, físico do acontecimento discursivo, pois é através do gesto, da indicação que o significado do dêitico se constrói. Os usos simbólicos dos termos dêiticos requerem apenas o conhecimento específico dos parâmetros espaço-temporais básicos do acontecimento discursivo e, 
ocasionalmente, o conhecimento dos parâmetros de papel dos participantes, de discurso e sociais.

Portanto, os aspectos dêiticos sempre estão presentes no contexto, mas é a configuração particular de cada um deles que criará um contexto específico. Vejam um exemplo: uma conversa no bar entre amigos. Como características gerais do contexto estão o lugar e a presença de falantes. $O$ endereço do bar, os sujeitos envolvidos na troca comunicativa, o ano, mês e dia do encontro, nos darão a construção do contexto específico que influenciará, por sua vez, a troca comunicativa entre os falantes envolvidos naquele momento na interação, tornando assim aquela interação única, singular.

Dessa forma, a importância de conhecer os contextos, segundo Van Dijk (2012), está no fato de que:

- controlam o modo como os participantes produzem e interpretam o discurso;

- habilitam os participantes a adaptar o discurso ou suas interpretações à situação comunicativa de acordo com a relevância para eles a cada momento da interação ou comunicação;

- proporcionam o elo cognitivo crucial que falta, na teoria cognitiva do processamento textual, entre os modelos mentais dos eventos de que se fala (referência), e o modo como o discurso é efetivamente formulado;

- definem as condições de adequação do discurso e, portanto, a base de uma teoria pragmática;

- são a base de uma teoria do estilo, do gênero textual, do registro e, em geral, de qualquer variação discursiva; são o elo faltante entre o discurso e a sociedade, entre o pessoal e o social e entre a organização em níveis e a estrutura [...] (p. 11-12)

Desse modo, podemos sintetizar a importância do contexto, em relação ao processo de produção e de interpretação de discursos, da seguinte forma: o contexto é importante na produção do discurso ao determinar o conjunto de escolhas discursivas que o falante deve efetuar e é igualmente importante na interpretação dos enunciados proferidos pelo interlocutor, em particular, para a identificação da significação implícita do discurso dirigido.

\subsubsection{Língua e contexto interacional: sala de aula}

Nossa pesquisa realizou-se em âmbito escolar, enfocando as interações verbais entre alunos e professoras durante uma aula de língua portuguesa e uma de língua italiana, ocorridas em uma escola bilíngue ítalo-brasileira, localizada na cidade de São Paulo. 
O contexto educacional formal configura os papéis dos participantes da pesquisa dentro da instituição de ensino. Nesse contexto, o professor detém um maior poder hierárquico em relação aos alunos, uma vez que ocupa o lugar de autoridade em sala de aula legitimado pelo conjunto de saberes que ele possui e pela incumbência de ensinar os saberes aos alunos. Assim, o discurso do professor em sala de aula - ou o discurso pedagógico em geral - ganha força e poder porque adquire o rótulo de ciência.

Orlandi (1987), ao analisar a construção e o funcionamento dos discursos, propõe a seguinte tipologia discursiva: lúdica, polêmica e autoritária. O critério para a distinção, segundo a autora, está na relação entre os interlocutores e o referente, ou seja, nas condições de produção. Assim, o discurso lúdico é, segundo ela, aquele em que seu objeto se mantém presente enquanto tal e os interlocutores se expõem a essa presença. É caracterizado pela interpretação individual, pela absoluta liberdade de pensamento. Já o discurso polêmico mantém a presença do seu objeto, sendo que os participantes não se expõem, mas procuram dominar o seu referente, dando-lhe uma direção. Há um equilíbrio tenso entre polissemia e paráfrase, isto é, há a possibilidade de mais de um sentido. No discurso autoritário, por sua vez, o referente está "ausente", oculto pelo dizer, não há realmente interlocutores, mas um agente exclusivo. Esse tipo de discurso apresenta uma polissemia contida, procurando impor um só sentido.

Segundo a autora, o discurso pedagógico é um tipo de discurso autoritário, porque se dissimula como transmissor de informação sob a rubrica da cientificidade. Escreve a autora

Como o professor, na instituição, é autoridade convenientemente titulada, e como ele se apropria do cientista, dizer e saber se equivalem. O professor é institucional e idealmente aquele que possui o saber e está na escola para ensinar, o aluno é aquele que não sabe e está na escola para aprender. (ORLANDI, 1987, p. 31)

Dessa maneira, o discurso pedagógico (DP) cria e reforça a noção de autoridade pela cientificidade. O professor é visto como o detentor do saber e como aquele que ensina aquilo que sabe (a ciência) aos alunos. O que o professor diz se converte em conhecimento, então, o papel do aluno é aprender com aquele que detém o conhecimento, ou seja, com o professor. Existem vários fatores presentes nesse processo que, além de fazer parte do discurso pedagógico fazem parte, também, da ordem social em que vivemos, que são: 
- a Lei da informatividade: para informar é preciso que o ouvinte desconheça o fato em si;

- a Lei do interesse: não se pode falar legitimamente a alguém senão aquilo que lhe possa interessar;

- a Lei da utilidade: não se fala somente por falar, mas porque há uma utilidade em fazêlo.

Portanto, tanto o professor quanto os alunos cumprem em sala de aula o papel que lhes foi atribuído pela instituição e pela sociedade. Ocorre a aceitação e a exploração dessas representações que fixam o professor como autoridade e reforçam a imagem do aluno como tutelado (ORLANDI, 1987). Em outras palavras, a imagem social do aluno é a de quem não sabe e está na escola para aprender e a imagem social do professor é a de quem possui o saber e está na escola para ensinar. Desse modo, as leis da informatividade, do interesse e da utilidade são satisfeitas na figura do professor, uma vez que sua fala informa e consequentemente possui interesse e utilidade.

Essa disparidade hierárquica entre professor e alunos é percebida não somente através do discurso em sala de aula, mas também no modo em que são administradas as interações verbais. Segundo Orletti (2014), quando os falantes não detêm os mesmos direitos e poderes durante a comunicação, a interação pode ser caracterizada como assimétrica.

Falar da disparidade do poder interacional significa entrar no campo das interações assimétricas, isto é, aquelas interações comunicativas onde não há igualdade de direitos e deveres comunicativos entre os interlocutores, mas os participantes diferem em acesso desigual aos poderes de gerenciar a interação.

[Parlare di disparità di potere interazionale significa entrare nel campo delle interazioni asimmetriche, cioè quelle interazioni comunicative in cui non si realizza fra gli interagenti una parità di diritti e doveri comunicativi, ma $i$ partecipanti si differenziano per un accesso diseguale ai poteri di gestione dell'interazione.] ( p. 12)

Ainda de acordo com Orletti, as interações assimétricas caracterizam-se pela presença de uma figura "guia", denominada pela autora de regista dell'interazione (a palavra "regista" em italiano indica o diretor de cinema ou de teatro), que controla o andamento da troca comunicativa nos seus múltiplos aspectos. 
O diretor é aquele que controla o poder interacional, isto é, tem acesso aos direitos negados aos outros participantes e exerce controle sobre o que os outros fazem e sobre o curso da interação. Uma definição mais transparente de interações assimétricas, pelo menos daquelas cuja assimetria se relaciona com a estrutura participativa, pode ser a seguinte: "Se considera assimétrica uma interação social onde um participante possui mais poder interacional do que os outros".

[Il regista è colui che controlla il potere interazionale, ha, cioè, accesso a diritti negati agli altri partecipanti ed esercita un potere di controllo su ciò che gli altri fanno e sull' andamento dell'interazione. Una definizione più trasparente di interazioni asimmetriche, almeno di quelle in cui l'asimmetria riguarda la struttura partecipativa, può essere la seguente: "si considera asimmetrica un'interazione sociale in cui un partecipante ha più potere interazionale degli altri".] (ORLETTI, 2014, p. 18)

Em sala de aula, o regista dell'interazione é o professor, pois é ele quem detém o controle da atribuição dos turnos durante a interação em sala de aula, a duração e o conteúdo deles, assim como a orientação dos temas do discurso.

Orletti (2014) afirma que embora existam diversos modos de exercer o poder de "regia", nos vários tipos de interação, é possível encontrar características comuns recorrentes que identificam o papel de tal figura guia. São elas:

- O "regista" abre e fecha a interação, delimitando fronteiras internas e externas em relação a todo o fluxo de relações sociais.

- [...] O "regista" atribui o direito de falar através dos vários procedimentos de hetero-distribuição de turnos.

- [...] O "regista" toma medidas que determinam uma importância condicional para tudo o que vem depois.

- [...] Exerce um controle sobre as questões em discussão, desde sua introdução através de movimentos de abertura, até a sua articulação em subtemas, seu desenvolvimento e sua conclusão. Na verdade, decide do que se fala e como se fala.

- Nos casos em que o acordo parece não acontecer entre os participantes sobre uma definição em andamento, tem o poder de restabelecer a ordem interacional através de comentários metacomunicativos que redefinem a estrutura contextual e o tipo de atividades interacionais envolvidas.

- [...] Tem o poder máximo para decidir se um comportamento está dentro das regras da interação em andamento ou se é uma insobordinação.

- [Il regista apre e chiude l'interazione delimitandone i confini interni ed esterni rispetto all'intero flusso dei rapporti sociali. (p. 18)

- [...] Il regista attribuisce il diritto a parlare attraverso le varie procedure di etero-allocazione dei turni. (p. 21)

- [...] Il regista mette in atto mosse che stabiliscono una rilevanza condizionale per tutto ciò che viene dopo. (p. 24)

- [...] Esercita un controllo sui temi in discussione, dalla loro introduzione attraverso le mosse di apertura, alla loro articolazione in sottotemi, al loro sviluppo, alla loro conclusione. Di fatto decide ciò di cui si parla e come se ne parla. (p.24) 
- Nei casi in cui sembra venir meno l'accordo dei partecipanti sulla definizione in corso ha il potere di ristabilire l'ordine interazionale attraverso commenti metacomunicativi che ridefiniscono la cornice contestuale e il tipo di attività interazionali in cui si è coinvolti. (p. 24)

- [...] Ha il potere ultimo di decidere se un comportamento rientra nelle regole dell'interazione in corso o se costituisce un'insubordinazione. (p. 26)]

Podemos assim entender melhor o papel desempenhado pelas professoras durante as interações verbais que analisamos em nossa pesquisa. Elas são as responsáveis pela organização das trocas comunicativas em sala. Nesse sentido, Orletti (2014) observa ainda que a transição dos turnos de um falante para outro, na interação em sala de aula, segue o seguinte esquema: professor-aluno-professor e

o professor está sempre no controle da troca comunicativa, iniciando e selecionando o próximo falante e retomando o turno imediatamente depois disso. O aluno pode tomar a palavra através da técnica de auto-seleção, mas apenas para produzir uma sequência subsidiária.

[in cui è sempre l'insegnante ad avere il controllo dello scambio comunicativo iniziandolo e selezionando il parlante successivo $e$ riprendendo immediatamente il turno dopo di questo. Lo studente può prendere la parola attraverso la tecnica dell'autoselezione, ma solo allo scopo di produrre una sequenza sussidiaria.] ( p.106)

Orletti (2014) chama a atenção, também, para o fato de que, além de uma relação assimétrica entre adulto/professor e criança/aluno, existe, contemporaneamente, em sala de aula, uma relação simétrica entre os alunos. Isso dá origem:

(...) a uma estrutura de interação mista e extremamente complexa, pois existem dois focos com status e diferentes direitos e deveres. A criança deve levar em conta dois tipos diferentes de interlocutores e organizar o seu comportamento dentro da interação em função de dois destinatários, ou seja, deve adotar dois pontos de vista diferentes e ser capaz de passar, de acordo com a predominância de um foco à outro, de um padrão de comportamento que rege interações entre os iguais a um relacionado a interações assimétricas, além de ter em mente as regras comportamentais específicas determinadas pelos objetivos pedagógicos atribuídos à interação social na situação escolar.

$[(\ldots)$ ad una struttura interazionale mista ed estremamente complessa in quanto si hanno due foci con status e relativi diritti e doveri diversi. Il bambino deve tener presenti due tipi diversi di interlocutore e organizzare il proprio comportamento all'interno dell'interazione in funzione di due destinatari, deve cioè adottare due diversi punti di vista, ed essere in grado di passare, in accordo al predominio di un focus rispetto all'altro, da un modello di comportamento regolante le interazioni fra pari ad uno relativo 
ad interazioni asimmetriche, oltre a dover tenere presenti le regole di comportamento specifiche determinate dagli obiettivi pedagogici attribuiti all'interazione sociale nella situazione scolastica. (ORLETTI, 2014, p. 9293)]

Diante disso, percebemos a complexidade das interações em sala de aula, marcada de um lado por relações simétricas entre os alunos e, de outro, por relações assimétricas entre professor e alunos. A relação assimétrica é assinalada pelo poder do professor em sala de aula certificado pelo discurso pedagógico autoritário do saber e pelo poder de administrar as interações verbais em sala de aula. Nesse sentido, o professor controla a distribuição dos turnos, a duração e o conteúdo deles, assim como orienta o tema do discurso em aula. $\mathrm{O}$ professor também detém o poder e o direito de realizar alguns atos de fala como o de perguntar, pedir, aconselhar, discordar, desaprovar, ordenar etc. Já a gama de direitos concedida aos alunos é menor, pois sendo o professor uma autoridade em sala de aula, é ele quem decide quais tipos de ato de fala são permitidos ou não aos alunos. Por exemplo, dificilmente um professor permitirá qualquer tipo de ato de fala que questione sua autoridade em sala de aula.

\subsubsection{Língua e contexto interacional: falantes bilíngues}

Como as crianças participantes de nossa pesquisa são falantes bilíngues, é útil apresentar algumas considerações sobre as especificidades do termo bilinguismo.

Atualmente, à palavra bilinguismo são atribuídas diversas concepções que nos remetem a experiências e contextos distintos. Popularmente, é bilíngue tanto o falante que passou pelo processo de aquisição de duas línguas, quanto aquele que aprendeu uma língua estrangeira em ambiente escolar. Logo, é considerado bilíngue quem sabe se comunicar em duas línguas.

Em relação ao contexto de aprendizagem, são chamadas bilíngues as escolas que oferecem programas escolares em duas línguas e, também, aquelas que disponibilizam o programa escolar em uma única língua estrangeira.

No entanto, é necessário considerar, na busca pela definição do termo bilinguismo, que as línguas apresentam diferentes níveis de competência comunicativa. Por exemplo, existem indivíduos que entendem perfeitamente uma segunda língua, isto é, que possuem uma habilidade de compreensão oral e escrita em uma língua, mas não possuem habilidade 
suficiente para nela se expressarem oralmente, ou seja, não possuem a habilidade de produção oral desenvolvida. Também há indivíduos que falam uma segunda língua, mas não sabem escrevê-la, em outras palavras, não possuem a habilidade de produção escrita na língua. Para Grosjean $(1989,1997)$, um falante bilíngue não é aquele que apenas fala duas línguas, mas aquele que possui capacidade verbal e comunicativa nas duas línguas, que é capaz, em diferentes níveis, de entender, falar, ler e ouvir em ambas as línguas.

Por outro lado, para Harmers e Blanc (2000) o bilinguismo pode ser classificado segundo as competências linguísticas relativas em cada língua. Os autores classificam o bilinguismo em bilinguismo balanceado (quando o indivíduo possui competência linguística equivalente em ambas as línguas) e bilinguismo dominante (quando o indivíduo possui maior competência linguística em uma das línguas, geralmente na língua que foi adquirida primeiro - L1). Chamamos a atenção para o fato de que essa classificação não abrange a competência pragmática, isto é, não considera o fato de o falante bilíngue saber, também, como agir de modo adequado e socialmente reconhecido nas duas comunidades culturais das quais tem conhecimento linguístico.

Em relação ao bilinguismo infantil, Harmers e Blanc (2000), levando em consideração o aspecto cognitivo, classificam-no como simultâneo ou consecutivo. $\mathrm{O}$ bilinguismo simultâneo ocorre quando a criança é exposta a duas línguas desde o nascimento e as adquire ao mesmo tempo. Já o bilinguismo consecutivo é decorrente da exposição à segunda língua depois da aquisição da língua materna, ou seja, o indivíduo adquire a L2 após ter assimilado as bases linguísticas da L1. Ainda em relação ao aspecto cognitivo, levando em consideração o enfoque semântico e conceitual, os autores identificam três tipologias de bilinguismo: composto, coordenado e subordinado. Fala-se em bilinguismo composto quando dois sistemas de signos linguísticos são associados a um só sistema de significado. O falante bilíngue, apesar de possuir dois esquemas linguísticos diversos, tende a reconduzi-los à mesma função de significado. O bilinguismo de tipo coordenado é quando o sujeito possui duas estruturas linguísticas adquiridas de maneira independente uma da outra e consegue controlá-las de maneira distinta. Nesse caso, o falante tem livre acesso aos dois esquemas linguísticos e é capaz de escolher, avaliar e usar as estratégias comunicativas que julga adequadas. $\mathrm{O}$ processo no qual as crianças adquirem primeiramente uma língua e depois uma segunda pode favorecer a um bilinguismo de tipo coordenado (separação dos dois sistemas linguísticos), já as crianças que são expostas simultaneamente a duas línguas podem vivenciar um bilinguismo de tipo composto. 
Contento et al. (2014) afirmam que a distinção entre bilinguismo coordenado e composto não é absoluta, ou seja, as diferentes formas de bilinguismo estão em um continuum que vai do extremo polo coordenado (independência dos dois sistemas linguísticos) ao polo composto (dependência e mistura das duas línguas em contato). Uma criança bilíngue simultânea ou consecutiva pode desenvolver, ao mesmo tempo, um sistema linguístico composto para certos conceitos e coordenado para outros. Além disso, pode preferir utilizar mais uma língua, embora tenha competência adequada de compreensão e produção em ambas. Já o bilinguismo subordinado ocorre quando o acesso ao sistema da segunda língua é mediado pelo sistema da primeira.

Outro aspecto que se refere ao bilinguismo é a importância dada às duas línguas no contexto social e afetivo do falante. Nesse caso, Harmers e Blanc classificam o bilinguismo como aditivo ou subtrativo. Nessa ótica, aditivo é o bilinguismo que oferece possibilidade de desenvolvimento social e que porta elementos positivos complementares para o desenvolvimento da criança. $O$ bilinguismo aditivo se refere àquelas situações em que o desenvolvimento de ambas as línguas e culturas é complementar e reúne elementos positivos para o funcionamento global da criança. Essa situação é possível quando a família e a comunidade atribuem valor positivo às duas línguas. Subtrativo é o bilinguismo que não oferece recursos, mas coloca o falante em condição de desvantagem, as duas línguas são concorrentes e não complementares. A língua que desfruta de maior prestígio social tende a substituir aquela materna que é sempre relegada a usos circunstanciais (âmbito familiar, da comunidade etc). As crianças que têm uma língua minoritária e que aprendem uma segunda língua majoritária se encontram frequentemente em contexto de bilinguismo subtrativo. Essa forma se desenvolve quando uma minoria rejeita a sua cultura em favor de uma outra língua culturalmente e economicamente mais prestigiosa. Neste caso, a segunda língua compromete a primeira.

Dessa forma, quando afirmamos que nossos participantes são falantes bilíngues, devemos ter em mente toda essa diversidade de fatores que interferem e moldam suas atividades comunicativas. A criança é um sistema aberto que se modela no decorrer do seu desenvolvimento social e afetivo. Durante tal percurso, é através da linguagem que se adquirem saberes e competências extra-escolares que irão construir o conjunto de conhecimentos do indivíduo. No processo de aquisição, a língua é um veículo de desenvolvimento integrado de diferentes componentes: cognitivo, social, afetivo, cultural. A 
criança aprende a linguagem da própria comunidade por meio da interação com os familiares, adultos, professores, outras crianças, etc.

A faixa etária dos participantes da nossa pesquisa (9-12 anos) foi escolhida porque, segundo Piaget (1978), a criança atravessa diversos estágios de desenvolvimento cognitivo e, em cada estágio desenvolve uma nova maneira de pensar e de responder ao ambiente. Quando a criança alcança a idade compreendida entre 7 e 11 anos está no período que ele denominou de operatório concreto. É nessa fase que o pensamento da criança passa a assimilar racionalmente a realidade e ela se torna capaz de pensar antes de agir, conseguindo organizar suas ideias e manipulá-las simbolicamente.

Outro motivo relevante é que nessa faixa etária a criança já concluiu o processo de alfabetização em uma das línguas e, portanto, possui um maior domínio da linguagem, conseguindo comunicar-se de forma oral e escrita. Dessa forma, acredita-se que, nessa fase, a criança tenha um maior domínio das habilidades de compreensão e de produção oral e escrita.

Portanto, é significativo conhecer as especificidades desse contexto, porque todos os fatores mencionados anteriormente se entrelaçam e estão presentes, como características constituintes dos atos de fala produzidos pelos alunos e professoras, uma vez que, o contexto influencia o discurso e é influenciado por ele.

\subsection{ATOS DE FALA}

\subsubsection{John Austin}

Como escrevemos no item 1.1, Austin introduziu a ideia do agir por meio das palavras, isto é, destacou a noção de performatividade da linguagem. Esse termo vem do inglês to perform e podemos entendê-lo como o ato de executar ou concretizar ações por meio das palavras.

Austin acreditava que fosse necessário diferenciar os enunciados constatativos (relacionados ao dizer) dos performativos (relacionados ao fazer). Os enunciados constatativos poderiam ser avaliados como verdadeiros ou falsos, porque poderiam ser verificados no mundo, já os enunciados performativos, por serem constituídos de ações, não poderiam ser classificados como verdadeiros ou falsos, mas apresentariam "condições de felicidade". As condições de felicidade, segundo Austin, são determinadas circunstâncias que 
influenciam a realização bem-sucedida (feliz) ou mal sucedida (infeliz) da enunciação. Austin (1990 [1962]) escreve:

(A.1) Deve existir um procedimento convencionalmente aceito, que apresente um determinado efeito convencional e que inclua o proferimento de certas palavras, por certas pessoas, e em certas circunstâncias; e além disso, que

(A.2) as pessoas e circunstâncias particulares, em cada caso, devem ser adequadas ao procedimento específico invocado.

(B.1) O procedimento tem de ser executado, por todos os participantes, de modo correto e

(B.2) completo.

( $\tau$.1) Nos casos em que, como ocorre com freqüência, o procedimento visa às pessoas com seus pensamentos e sentimentos, ou visa à instauração de uma conduta correspondente por parte de alguns dos participantes, então aquele que participa do procedimento, e o invoca deve de fato ter tais pensamentos ou sentimentos, e os participantes devem ter a intenção de se conduzirem de maneira adequada, e, além disso,

$(\tau .2)$ devem realmente conduzir-se dessa maneira subseqüentemente. (p.31)

Dessa forma, as condições de felicidade que os atos de fala devem atender são condições relacionadas à competência linguística (condições que Austin chamou de A), ao procedimento ou forma de execução do ato (condições que o filósofo chamou de B) e condições $\tau$ que se relacionam aos estados internos do falante: sua sinceridade e seu comportamento.

Mais tarde, Austin percebeu que a associação constatativos-condição de verdade e performativos-condição de felicidade não funcionava, pois enunciados constatativos podiam ser julgados como felizes ou infelizes e enunciados performativos também estavam sujeitos a julgamentos de verdade ou de falsidade. Então, o filósofo logo percebe que "dizer" compreende sempre "fazer" e que descrever o mundo é somente uma das tantas ações possíveis de realizar por meio dos enunciados da linguagem natural. Por esse motivo, Austin propõe abandonar a dicotomia constatativo/performativo em favor de uma teoria dos atos de fala, ou seja, de uma teoria acional concretizada pelo uso da linguagem.

$\mathrm{O}$ ato de fala é o ato de agir por meio da fala. Para o filósofo, o agir linguístico se fundamenta no acordo interpessoal que é ancorado nas convenções compartilhadas socialmente, ou seja, Austin vê a ação da linguagem como uma tarefa que envolve as convenções sociais que regem um determinado contexto e as intenções do falante no momento da troca comunicativa. A missão do interlocutor não é compreender aquilo que o falante gostaria de dizer, mas reconhecer a ação que está sendo colocada em cena, dentro de 
um procedimento social que envolve relações de poder. Desse modo, realizar um ato de fala é um trabalho que envolve não só o falante, mas também o interlocutor que assume o papel de reconhecer se aquele ato de fala é válido ou não. Para ilustrar essa ideia, Caffi (2009) dá o exemplo da ordem, e afirma que para que um ato possa ser reconhecido como uma ordem, é necessário que todas as condições de felicidade do ato sejam satisfeitas, isto é, que evidenciem um procedimento socialmente estabelecido e que o destinatário reconheça o ato como tal, caso contrário será apenas uma tentativa e não a realização concreta de uma ordem. Portanto, a ideia austiniana de ato de fala estabelece uma dimensão convencional, no sentido de que as normas presentes no contexto determinam a configuração do ato de fala e uma dimensão dialógica e intersubjetiva, no sentido de que ao interlocutor é dado o papel crucial para a feliz realização do ato.

Austin divide todo ato de fala em três níveis, isto é, cada ato apresenta as seguintes dimensões: ato locucionário, ato ilocucionário e ato perlocucionário.

O ato locucionário é o ato de dizer alguma coisa. Cada ato de fala é o ato de proferir uma expressão linguística sintaticamente correta e dotada de um significado. $O$ ato locucionário decompõe-se em: ato fonético, ato fático e ato rético. $\mathrm{O}$ ato fonético é o ato de emitir certos sons, o ato fático é o ato de pronunciar certos sons (entonação) e o ato rético é o ato de utilizar as palavras com um determinado significado. Resumindo, o ato locucionário é a dimensão acústica do ato de fala.

O ato ilocucionário, por sua vez, é o ato que se realiza no dizer algo. Corresponde à ação que é executada ao proferir um enunciado dotado de significado em um determinado contexto. Cada ato de fala, portanto, é caracterizado por uma força ilocucionária, isso quer dizer que um ato de fala pode ter a força ilocucionária de uma ordem, de um conselho, de uma pergunta, de uma sugestão, de uma discordância, de uma desaprovação etc. $O$ ato ilocucionário é um ato convencional, porque para a sua realização é necessário proferir o enunciado com uma determinada força convencional e seguir o procedimento convencional que o regula. É por essa razão que o mesmo ato locucionário pode veicular diversos atos ilocucionários, pois se mudarmos a força ilocucionária ou seu procedimento convencional, muda-se também o ato. Por exemplo: "Abra a porta, por favor!", dependendo da força ilocucionária utilizada para o ato, pode realizar um pedido ou uma ordem. Em outras palavras, o ato ilocucionário depende da intenção do falante e da força da enunciação que ele escolhe realizar seu ato de fala. $\mathrm{O}$ ato ilocucionário é a dimensão propriamente acional da linguagem. 
Já o ato perlocucionário é o ato que se realiza com o dizer algo e está relacionado às consequências intencionais e não intencionais que é possível atingir executando um ato de fala. Por exemplo, argumentando o falante pode persuadir ou convencer o interlocutor; aconselhando-o, pode assustá-lo ou preveni-lo etc. Assim, a dimensão do ato perlocucionário relaciona-se aos efeitos que um determinado ato de fala pode produzir no interlocutor.

Ao contrário do ato ilocucionário, o ato perlocucionário tem uma natureza não convencional, porque, de fato, os efeitos de um ato de fala não são calculáveis, uma vez que dependem das características particulares da circunstância em que o enunciado foi proferido, logo, são fortemente dependentes do contexto. Assim sendo, as consequências sob os interlocutores podem ser de natureza comportamental e psicológica. A noção de ato perlocucionário não foi explorada por Austin com muita profundidade e clareza e até hoje é um dos aspectos menos estudados da teoria dos atos de fala (cf. DOMANESCHI, 2014).

Para os atos ilocucionários, Austin propôs uma classificação pautando-se unicamente nos tipos de verbos e na força ilocucionária que eles veiculam. Escreve o autor:

Classifiquei essas classes de proferimentos em função de sua força ilocucionária, e lhes darei os seguintes nomes:

1) Veriditivos.

2) Esercitivos.

3) Comissivos.

4) Comportamentais (um horror este neologismo!)

5) Expositivos

Vamos considerá-los em ordem, mas antes quero dar uma idéia esquemática de cada um.

Os primeiros, veriditivos, caracterizam-se por dar um veredito, como o nome sugere, por um corpo de jurados, por um árbitro, ou por um desempatador (terceiro árbitro). Mas não é necessário que sejam definitivos. Podem constituir uma estimativa, um cálculo, uma apreciação. Constituem essencialmente de algo- fato ou valor- a respeito do qual, por diferentes razões, é difícil se estar seguro.

Os segundos, exercitivos, consistem no exercício de poderes, direitos ou influências. Por exemplo: designar, votar, ordenar, instar, aconselhar, avisar, etc.

Os terceiros, comissivos, caracterizam-se por prometer ou de alguma forma assumir algo; comprometem a pessoa a fazer algo, mas incluem também declarações ou anúncios de intenção, que não constituem promessas, e incluem também cisas um tanto vagas que podemos chamar de adesões, como, por exemplo, tomar partido. Tem conexões óbvias com os veriditivos e os exercitivos.

Os quartos, comportamentais, constituem um grupo muito heterogêneo, e têm a ver com atitudes e comportamento social. Exemplos são: pedir desculpas, felicitar, elogiar, dar os pêsames, maldizer e desafiar.

Os quintos, expositivos, são difíceis de definir. Eles esclarecem o modo como nossos proferimentos se encaixam no curso de uma argumentação ou 
de uma conversa, como estamos usando as palavras, ou seja, são, em geral expositivos. Exemplos são: "contesto", "argumento", "concedo", "exemplifico", "suponho", "postulo". (AUSTIN, 1990 [1962], p. 123-124)

Dessa maneira, resumidamente, temos as seguintes classes de atos de fala:

1. Veriditivos: relacionam-se ao juízo de verdade. Ex: julgar, avaliar, diagnosticar;

2. Exercitivos: relacionam-se ao exercício de poder, de direitos. Ex: ordenar, demitir, conceder;

3. Comissivos: relacionam-se ao comprometimento, a obrigação futura. Ex: prometer, propor, apostar;

4. Comportamentais: relacionam-se aos comportamentos e atitudes sociais. Ex:desculpar-se, parabenizar, agradecer;

5. Expositivos: relacionam-se à exposição dos próprios argumentos. Ex: afirmar, negar, perguntar

As cinco classes de atos ilocucionários propostas por Austin são uma primeira tentativa de classificação das diversas possibilidades de uso da linguagem cotidiana, contudo, trata-se de uma classificação incompleta e problemática. Dentre os principais problemas, está o fato de que o filósofo propõe, na verdade, não uma classificação de tipos de atos de fala, mas uma classificação de verbos e tais verbos, muitas vezes, podem se encaixar em várias categorias simultaneamente. Além disso, alguns verbos elencados por ele não satisfazem a definição da classe na qual foram inseridos.

\subsubsection{John Searle}

Em 1969, o filósofo americano John R. Searle publica a obra Speech Acts, propondo uma revisão da teoria dos atos de fala de Austin. O filósofo, que havia estudado com Austin, seleciona o ato ilocucionário como unidade central de análise e critica a tripartição austiniana de ato de fala em ato locucionário, ilocucionário e perlocucionário, sustenta que todos os atos de fala são caracterizados apenas por dois componentes: o conteúdo proposicional e a força ilocucionária. O seu principal esforço é o de tentar identificar as regras que constituem e que regulam os diversos atos de fala.

Nesse sentido, Searle identifica três principais dimensões de variação dos atos de fala: (i) o objetivo ilocucionário (é o motivo pelo qual se profere um enunciado com uma 
determinada força ilocucionária); (ii) a direção de adequação palavra-mundo (se o objetivo do proferimento é adaptar o mundo às palavras, isto é, descrever a realidade (ex: O gato está em cima do tapete) ou de adaptar as palavras ao mundo, ou seja, modificar a realidade (ex: Retire o gato de cima do tapete!). Em outras palavras, a direção de adequação é a consequência do objetivo ilocucionário; (iii) o estado psicológico expresso (é o sentimento do falante em relação ao conteúdo expresso pelo ato de fala). Com base nessas variáveis, Searle propõe sua classificação dos atos de fala em:

Assertivos ou Representativos: Nessa categoria entram diversos atos que Austin catalogou na classe dos expositivos. O objetivo ilocucionário dos assertivos é levar o falante a cumprir um ato de fala em relação à verdade do conteúdo da proposição afirmada. Todos os assertivos exprimem o estado psicológico de uma crença. A direção de adequação vai das palavras ao mundo. Exemplos são as descrições, as explicações, as afirmações, as conclusões etc.

Diretivos: O objetivo ilocucionário dos diretivos é impulsionar alguém a fazer alguma coisa. A direção de adequação vai das palavras ao mundo. O conteúdo dos diretivos descreve sempre uma ação futura e exprime a vontade da parte do falante de induzir o interlocutor a executar ações futuras. São exemplos as ordens, pedidos, conselhos, súplicas e convites.

Comissivos: Coincidem quase inteiramente com a classe dos comissivos traçada por Austin. O objetivo ilocucionário é o comprometimento do falante a realizar uma ação futura. A direção do vetor de adequação vai das palavras ao mundo e o estado psicológico expresso pelos comissivos é a intenção do falante de executar um determinado ato no futuro. Nessa categoria incluem-se as promessas, apostas, juras.

Expressivos: É similar a categoria dos comportamentais de Austin. O objetivo ilocucionário desses atos é expressar o estado psicológico do falante em relação ao conteúdo da proposição e, ao mesmo tempo, solicitar do interlocutor um certo tipo de conduta. A direção de adequação é nula. São exemplos de expressivos os atos de agradecer, desculpar-se, lamentar-se, perdoar, agradecer, cumprimentar.

Declarativos: O objetivo ilocucionário dos declarativos é produzir uma situação de correspondência entre o conteúdo da proposição expressa com o mundo. Por este motivo, possuem uma dupla direção de adequação, do mundo para as palavras e das palavras para o mundo. Portanto, os declarativos produzem uma situação nova na realidade. São exemplos os atos de batizar, casar, condenar etc. 
Searle, ao introduzir a ideia de que só os atos declarativos têm a capacidade de fazer aquilo que dizem e de dizer aquilo que fazem, se distancia de Austin. A teoria de Austin enfocava as formas da linguagem dentro do agir social e sua validade dentro dele, já para Searle o que importa é a força de um determinado ato de fala. Para Austin, o que importa é a convencionalidade, ou seja, para que um ato de fala se realize de forma bem-sucedida é necessário seguir um procedimento convencional e, para Searle, o que conta é a intencionalidade, isto é, para a feliz realização de um ato de fala é necessário que as intenções do falante sejam reconhecidas pelo interlocutor.

Quando um ato ilocucionário é concretizado indiretamente através da execução direta de outro tipo de ato ilocucionário, ele é chamado de ato de fala indireto. $\mathrm{O}$ termo e o conceito foi proposto por Searle (1979) e, segundo o filósofo, em um ato de fala indireto o falante realiza um ato ilocucionário com determinada forma, mas com um objetivo ilocucionário que vai além, isto é, que ultrapassa seu sentido literal. Por exemplo, quando perguntamos para alguém "Você tem horas?" não esperamos que o interlocutor responda simplesmente que sim ou que não, mas por trás de nossa pergunta está a intenção de saber de fato as horas naquele momento. Em outras palavras, a forma é de uma pergunta, mas a função é de um pedido indireto (Você poderia me dizer as horas?), isto é, pergunto se a pessoa tem horas porque quero saber que horas são.

Retomando a noção de língua e contexto(s) e o que afirma Bakhtin a propósito da linguagem, relembramos o conceito de que a linguagem é ideológica porque veicula uma ideia e a ideia só existe porque existe um contexto com o qual o ser humano se relaciona. A teoria dos atos de fala de Austin considera a linguagem como um agir social dentro de um contexto. Como a noção de contexto já foi introduzida na sessão 1.2 do trabalho, neste momento, abordaremos as concepções de contexto, para Austin e Searle, e atos de fala, a partir das considerações de Sbisà (2002) sobre o assunto.

A autora chama a atenção para o fato de que tanto os atos de fala diretos quanto os indiretos encontram condições para a sua realização bem-sucedida (ou condição de felicidade nas palavras de Austin) dentro do contexto. Porém, na teoria proposta por Austin, o contexto parece ser concebido como um conjunto de estados reais pré-determinados e que funcionam como palco para a emissão dos atos de fala. Logo, o filósofo não considera as características do contexto que podem influenciar a produção dos atos de fala e nem os estados psicológicos dos falantes. A preocupação de Austin está centrada somente na competência linguística do falante, na forma de execução do ato e nas condições que se relacionam com a sinceridade do 
falante durante a enunciação. Portanto, dentro dessa visão, o contexto exerce apenas um papel avaliativo, isto é, o de determinar ou não o sucesso na realização de um ato de fala.

Em Searle, a concepção de contexto começa a mudar e o contexto passa a ser considerado mais como um conjunto de atitudes proposicionais dos participantes do que um conjunto de estados reais naturais. As condições de felicidade de um ato de fala começam a ser formuladas em termos de crenças ou intenções dos participantes e esse fato influencia a própria concepção de ato de fala. Passa-se de uma visão de ato de fala como ação de efeitos convencionais, para uma visão de ato de fala como enunciados que expressam intenções comunicativas (SBISÀ, 2002, p. 424).

Ainda sobre o papel do contexto, Sbisà (2002) salienta que as inferências por meio das quais o ouvinte reconhece a intenção comunicativa do falante são baseadas em crenças contextuais, isto é, crenças compartilhadas pelos falantes e ativadas pelo contexto de expressão. Em outras palavras, as condições para que uma dada expressão se constitua em um ato ilocucionário de certo tipo são fornecidas, em grande parte, por fatores situacionais sociais.

Assim, para que o ouvinte consiga entender o ato de fala indireto deve percorrer um caminho de inferências considerando os aspectos do contexto no qual o ato se realizou. De acordo com essa perspectiva, a força ilocucionária indireta é inferida quando a força literal de um ato de fala é inadequada em um determinado contexto conversacional. Para Searle, as normas conversacionais que estabelecem adequação da força ilocucionária literal de um ato de fala correspondem aos princípios conversacionais de Grice.

\subsubsection{Princípio de cooperação: máximas conversacionais e implicaturas}

Paul Grice dedicou seus estudos à análise da conversação e apesar de seu foco não ter sido a conversação real e sim a conversação ideal, o teórico criou um modelo que influenciou os estudos sobre conversação. Para Grice, o agir comunicativo é uma atividade racional pautada em procedimentos racionais. Nesse sentido, toda e qualquer conversa quotidiana, embora aparente ser confusa e desordenada, é regida por uma forma de colaboração tácita entre os falantes e por um articulado sistema de expectativas.

Assim, para que uma conversação se realize de modo adequado, existe a necessidade de cooperação entre os interlocutores, isto é, essa forma particular de comportamento é regida pelo princípio, chamado por Grice, de cooperação. Tal princípio permite que os interlocutores 
possam manter um comportamento racional durante a troca verbal e assim realizar suas intenções comunicativas. Mas o que significa manter um comportamento cooperativo e racional quando se usa a linguagem? Grice (1975) defende que é necessário respeitar quatro tipo de máximas: de quantidade, de qualidade, de relação e de modo.

A máxima da quantidade determina que um falante não deve proferir enunciados que forneçam mais ou menos informações do que foi perguntado.

A máxima da qualidade enfatiza que a contribuição deve ser verdadeira, ou seja, não dizer aquilo que acredite ser falso e nem dizer aquilo de que não se tem provas.

Já a máxima de relação diz respeito à pertinência, isto é, um falante racional e cooperativo deve fornecer informações pertinentes ao conteúdo da conversação. A pertinência das informações, por sua vez, pode variar dentro da mesma troca comunicativa, uma vez que os argumentos de uma conversação mudam constantemente no curso de uma interação verbal.

E, por fim, a máxima de modo exige clareza naquilo que está sendo proferido, portanto, devem ser evitadas obscuridade de expressão e ambiguidade. Além disso, é necessário também ser conciso e organizado. A máxima de modo não se relaciona ao conteúdo em si, mas ao modo no qual um conteúdo é expresso.

$\mathrm{O}$ respeito às máximas garante uma conversação cooperativa, eficiente e racional. Todavia, nas conversações cotidianas, os participantes frequentemente violam uma ou mais máximas. Como, no entanto, os interlocutores presumem, mesmo nesses casos, que o princípio de cooperação geral deva ser mantido, procuram interpretar o enunciado identificando o motivo da violação, isto é, fazem o que Grice chamou de implicatura. Os interlocutores tentarão identificar naquilo que não foi dito de modo explícito as intenções do falante presentes de forma implícita.

Nesse sentido, o conceito de ato de fala indireto de Searle relaciona-se com a análise de Grice sobre a violação das máximas e as implicaturas, pois o princípio é o mesmo: o falante realiza um ato de fala e seu interlocutor não o compreende em sentido literal mas, indiretamente, fazendo uma inferência, como acontece, por exemplo, quando alguém diz "Está quente aqui" e a afirmação é entendida como um pedido para abrir uma janela ou ligar o ar condicionado.

As máximas propostas por Grice são idealizações racionais que funcionam como um direcionamento ou princípios que poderiam orientar os falantes durante uma conversação. $\mathrm{O}$ autor distingue dois tipos de implicatura: a convencional e a conversacional. 
As implicaturas convencionais são as inferências que fazem parte do significado funcional verdadeiro de um lexema, de uma expressão ou de uma construção sintática. Portanto, são implicaturas cristalizadas no uso de certas expressões. Por exemplo, no enunciado "Marco é pobre mas é honesto", o uso do conector "mas" ativa a implicatura que ser pobre é igual a ser desonesto. Em outras palavras, é um elemento linguístico presente na frase que ativa uma implicatura, por isso Grice a chama de implicatura convencional.

Já as implicaturas conversacionais ocorrem quando uma ou mais máximas de cooperação conversacional são violadas. Quando, por exemplo, a amiga A pergunta para a amiga B "Vamos ao cinema?" e a amiga B responde "Não tenho dinheiro", foi violada a máxima da quantidade - aquela que estabelece que um falante não deve fornecer mais e nem menos informações a respeito do que foi perguntado - obrigando a amiga A a ativar um processo de inferência relacionado ao seu conhecimento de mundo, que leva a saber que para ir ao cinema é necessário dispor de dinheiro para a compra de ingressos e assim, a compreender que sua amiga não vai ao cinema.

Grice define as implicaturas conversacionais por meio de cinco critérios. De maneira sintética e simplificada uma implicatura conversacional é:

1. Calculável. Quer dizer que a compreensão de uma implicatura conversacional não é automática e exige uma série de passos inferenciais com o objetivo de dar coerência à troca comunicativa.

2. Não é destacável. Significa que a implicatura conversacional é ligada ao conteúdo semântico de um enunciado e não à sua forma linguística. Diferentemente da implicatura convencional, na qual se mudarmos a forma linguística, mudamos também a inferência, a implicatura conversacional mantém a inferência, mesmo se for substituída por um sinônimo. No exemplo anterior quando a amiga A pergunta para a amiga B "Vamos ao cinema?" e a amiga B responde "Não tenho dinheiro", se tivesse usado um sinônimo no lugar de "dinheiro" e tivesse dito "Não tenho verba", a inferência continuaria a mesma.

3. Não é convencional. Isto é, não está condicionada a uma estrutura linguística específica.

4. É indeterminada. Porque a implicatura conversacional não é uma inferência lógico-dedutiva e depende de vários fatores contextuais.

5. É cancelável. A implicatura conversacional é cancelável no sentido que é possível acrescentar informações durante a conversação que possam anulá-la. 
Assim sendo, as implicaturas convencionais e conversacionais, na visão de Grice, coincidiriam com as pressuposições. Como veremos a seguir, o conceito de implicaturas ajudou a estabelecer o conceito de pressuposições pragmáticas.

\subsubsection{Pressuposições semânticas e pragmáticas}

O conceito de pressuposição foi amplamente desenvolvido no âmbito da Linguística e da Filosofia da linguagem. É possível encontrar duas distinções entre pressuposições: as semânticas e as pragmáticas. As pressuposições semânticas relacionam-se com a lógica da linguagem e englobam as visões de Frege, Russell e Strawson. Já as pressuposições pragmáticas são muito sensíveis a fatores contextuais e restringem-se a certas inferências ou suposições pragmáticas, relacionando-se praticamente com a teoria de Grice sobre a implicatura conversacional.

Sobre as pressuposições semânticas, Frege (1892) sustentava que o uso de um determinado termo pressupunha a existência do próprio objeto ou do indivíduo indicado. Assim, dizer "Kepler morreu na miséria" para receber valor de verdade deve pressupor que "Kepler existiu". Embora as duas frases veiculem conteúdos diferentes, estão ligadas entre si pelo fato de que a verdade de uma é condição necessária para a verdade da outra. Dessa forma, a frase "Kepler existiu" pode ser considerada uma pressuposição semântica de "Kepler morreu na miséria". Frege afirmava também que enunciados como "Ulisses existiu" e "Papai Noel existe" não poderiam ser avaliáveis como verdadeiros ou falsos, a razão seria que os termos "Ulisses" e "Papai Noel" não denotariam nenhum objeto ou indivíduo existente.

Russell (1905) criticou a teoria de Frege, principalmente, no que diz respeito à avaliação de enunciados com termos que não denotariam nenhum objeto ou indivíduo. Para Russell, a função de um nome próprio, como "Ulisses" ou "Papai Noel" não é pressupor a existência do indivíduo denotado. Russell dá o seguinte exemplo "O atual rei da França é careca", para o filósofo, a frase exprime três declarações conjuntas: a-) que existe um indivíduo que é o atual rei da França; b-) que quem quer que seja o atual rei da França é igual a esse indivíduo e c-) que tal indivíduo é careca. Assim, a frase só será verdadeira se o conjunto a-), b-), c-) também o for, caso contrário, a pressuposição resulta falsa. Portanto, para Russell todos os enunciados da linguagem podem ser verdadeiros ou falsos, até aqueles que apresentam expressões sem referência. 
Strawson (1950) apresenta diversas objeções à teoria de Russell, afirmando que o filósofo não percebeu que na fala existe o nível dos enunciados (uma sequência de expressões linguísticas) e o nível da enunciação (o uso de um enunciado em um contexto específico). A partir disso, Strawson propõe uma distinção entre denotação e referência. A denotação é o nível dos enunciados e pode ser descrita como uma relação entre uma expressão e o objeto ou entre o indivíduo que tal expressão designa convencionalmente. Já a referência é a relação entre a expressão e o objeto ou indivíduo a que o falante tem a intenção de referir-se utilizando tal expressão em um particular contexto de uso. Desse modo, a frase "O atual rei da França" poderia ser usada para fazer referência a qualquer pessoa real, o problema da veracidade ou da falsidade dos enunciados se coloca somente em relação ao proferimento e ao fato que uma determinada expressão assuma ou não uma referência em uma determinada ocasião de uso. Em outras palavras, a frase isolada "O atual rei da França é careca" não pode ser considerada verdadeira ou falsa, mas seu proferimento dentro de um determinado contexto pode resultar verdadeiro ou falso.

Austin (1962), ao introduzir a sua teoria dos atos de fala, introduziu também um novo conceito de pressuposição, não mais ligado às condições necessárias para a avaliação da verdade ou da falsidade de um enunciado, mas à condição de felicidade de um ato de fala, isto é, uma condição que deve ser satisfeita na enunciação para atingir seu objetivo. Dito de outra maneira, a ausência ou a falsidade de uma pressuposição viola as condições de felicidade e a enunciação resulta fracassada ou infeliz. Imaginemos, por exemplo, que o falante A dissesse a B "Empresto a minha bicicleta para você". Se não existisse uma bicicleta ou se fosse falso o fato de A possuir uma bicicleta, a falta da pressuposição de existência ou sua falsidade tornaria A incapaz de executar com sucesso sua promessa e, portanto, o proferimento seria infeliz.

Dessa forma, a proposta de Austin representa um primeiro passo em direção a uma noção pragmática de pressuposição, uma vez que, dentro dessa perspectiva, as pressuposições relacionam-se ao uso apropriado dos enunciados. Porém, segundo Domaneschi (2014), Austin propõe uma abordagem que pode ser considerada ainda semântica sobre as pressuposições, por dois motivos: a-) as pressuposições, segundo Austin, estão estreitamente ligadas ao uso de determinadas expressões linguísticas e b-) a pressuposição é caracterizada ainda como relação semântica entre enunciados. 
O tratamento das pressuposições como um fenômeno pragmático foi inspirado, principalmente, pela teoria das implicaturas de Grice (1975), ou seja, na distinção entre o que é dito explicitamente e o que é implicado pelo falante, como já foi visto anteriormente.

Segundo Domaneschi (2014), a ideia de Grice segundo a qual as pressuposições correspondem ao significado implicado por um falante contribuiu para consolidar a tese de que as pressuposições têm uma natureza pragmática, isto é, não são diretamente ligadas a interpretações semânticas de um enunciado, mas possuem estreita relação com os falantes, com suas crenças, com suas intenções e com seus estados mentais.

A partir das considerações de Grice, diversos autores desenvolveram suas teorias sobre as pressuposições, uma delas é a de Stalnaker (2002), que se baseia na ideia de um terreno comum (common ground) de assuntos compartilhados entre os falantes que interagem em uma conversação. Stalnaker propõe uma noção pragmática de pressuposição que pode ser definida do seguinte modo: um enunciado $p$ pressupõe pragmaticamente $q$ se e somente se o proferimento de $p$ resulta apropriado e apenas se $q$ pertence ao common ground. Imaginemos o seguinte exemplo: Maria está hospedada em um hotel e telefona para a recepção para pedir uma toalha de banho. Nesse contexto, são pressuposições pragmáticas: (i) o hotel possuir toalhas de banho e, (ii) o hotel oferecer toalhas de banho aos hóspedes como parte do serviço de hospedagem. Portanto, o pedido de Maria resulta apropriado somente dentro desse contexto, uma vez que, se (i) e (ii) não fossem pressuposições compartilhadas pelos falantes, o pedido de Maria seria considerado inapropriado.

A noção de pressuposição pragmática proposta por Stalnaker se diferencia da pressuposição semântica, porque as pressuposições pragmáticas não são caracterizadas pela relação semântica entre enunciados, mas como uma relação entre enunciações e falantes, assim pressupor é uma ação que o falante realiza em relação a uma enunciação. Fato que confirma, mais uma vez, o caráter acional da linguagem proposto por Austin. As pressuposições pragmáticas não se relacionam com a avaliação da verdade ou da falsidade dos enunciados proferidos pelos falantes, mas com a adequação dos proferimentos. As pressuposições pragmáticas não estão necessariamente ligadas aos usos de determinadas expressões linguísticas, mas Stalnaker reconhece a presença de alguns ativadores pressuposicionais (presupposition triggers) que são elementos lexicais ou construções sintáticas que, se utilizadas no interior de um enunciado, ativam pressuposições. Dessa forma, Stalnaker reconhece que as pressuposições são, em parte, ligadas à semântica das expressões utilizadas no interior de um enunciado. Tal fato, segundo Domaneschi (2014), parece 
favorecer um acordo, pelo menos em parte, entre a noção de pressuposição semântica e pressuposição pragmática.

As pressuposições compartilhadas, ou que se tornam tais durante a troca comunicativa, representam importantes fatores da constituição do contexto. Os usos das pressuposições comportam como vantagem colocar em segundo plano as coisas que em primeiro plano poderiam criar algum tipo de problema entre os falantes.

Como foi dito na sessão 1.1 deste trabalho, cada cultura faz um recorte diferente da realidade, assim cada situação social cultural, cria sua rede de saberes compartilhados dentro daquela comunidade. Portanto, nossa pesquisa não objetiva entender somente as condições para a realização bem-sucedida de um determinado ato de fala, mas investigar também quais são os efeitos que determinados atos de fala causam no discurso e na relação entre os interlocutores dentro de um contexto social cultural específico. Para isso, investigaremos as normas de relacionamento e respeito social que se sustentam nas regras de cortesia verbal. É a elas que dedicaremos a próxima seção.

\subsection{CORTESIA VERBAL}

O princípio de cooperação e o respeito às máximas conversacionais favorecem uma conversação cooperativa, eficiente e racional (MARIOTTINI, 2007, p. 12). Conseguir a colaboração do destinatário, segundo Escandell Vidal (1996), é uma tarefa fundamental e integra também os objetivos da comunicação, nesse sentido, afirma a autora, o falante atua sobre o interlocutor e tal atuação é permeada por normas sociais. Ao conjunto de normas sociais que regulam a atuação dos falantes dentro de uma sociedade é dado o nome de cortesia. De acordo com Escandell Vidal (1996), a cortesia pode ser entendida como

um conjunto de normas sociais, estabelecidas por cada sociedade, que regem o comportamento adequado de seus membros proibindo algumas formas de conduta e favorecendo outras: o que se ajusta às normas é considerado cortês e o que não se encaixa é sancionado como descortês.

[un conjunto de normas sociales, establecidas por cada sociedad, que regulan el comportamiento adecuado de sus miembros prohibiendo algunas formas de conducta e favoreciendo otras: lo que se ajusta a las normas se considera cortés, y lo que no se ajusta es sancionado como descortés.] (p. 136) 
Desse modo, se a cortesia é um conjunto de normas sociais que regula o comportamento dos indivíduos dentro de uma sociedade, a cortesia verbal, por sua vez, é um conjunto de normas que rege o comportamento dos indivíduos durante uma troca comunicativa verbal.

Em 1973, a linguista Robin Lakoff individuou três máximas que contribuiriam para identificar um comportamento cortês:
(a) Não se impor
(b) Dar opções
(c) Fazer o ouvinte se sentir bem; ser amigável
[(a) Don't impose
(b) Give options
(c) Make the listener feel good; be friendly ] (p. 293-298)

Essas máximas que conduzem o indivíduo a não impor a sua vontade ao interlocutor, mas a indicar opções e a fazer com que o interlocutor "se sinta bem", constituem as noções básicas dos estudos atuais sobre cortesia verbal. Para Lakoff (1973), a cortesia é um sistema de relações interpessoais que cumpre o papel de facilitar a interação, por meio da minimização do conflito e de potenciais confrontos nas trocas comunicativas.

\subsubsection{Erving Goffman}

Em 1986, o sociólogo canadense Erving Goffman propôs, em seus estudos sobre interações cotidianas, que no nosso comportamento comunicativo está presente, além de um núcleo formal e sistêmico que compreende a nossa competência linguística, um conjunto de princípios que regem nossas interações. A esse conjunto de princípios que moldam nossas interações Goffman chamou de frame. O autor define frame como o conjunto de princípios de organização que governam acontecimentos sociais e nosso envolvimento subjetivo neles (GOFFMAN, 1986, p. 10-11). Dessa forma, os frames são formatos interativos determinados por cada tipo de situação e contexto, logo as características de cada ritual comunicativo variam de acordo com o contexto no qual está inserida a interação verbal.

$\mathrm{Na}$ nossa pesquisa, a interação verbal ocorre em sala de aula. Esse espaço tem como característica constitutiva ser um local de instrução formal, onde, no mínimo, duas pessoas estão reunidas, sendo uma o aluno e outra o professor, com o objetivo de aprendizagem. $\mathrm{O}$ 
contexto, como já afirmado anteriormente, é construto dos participantes que, durante a interação, elaboram juntos o discurso, o qual também influenciará o próprio contexto de produção. Assim, o ritual interativo (frame) em sala de aula é caracterizado, essencialmente, por explicações, formulação de questões e devolutivas. Nessas interações, podem estar presentes vários tipos de atos de fala, tais como pedidos, afirmações, negações, avaliações, agradecimentos etc. Nossa pesquisa se deterá na análise dos atos de fala de discordância e desaprovação realizados durante a interação em sala de aula e em seus efeitos nas relações pessoais entre os falantes.

Para Goffman, a vida social poderia ser descrita como uma representação teatral em que os falantes seriam atores sociais. Desse modo, uma aula escolar corresponderia a uma atividade social disciplinada por rituais que estabelecem o comportamento apropriado de cada ator participante (professor e alunos) e os frames seriam papéis sociais desempenhados por atores sociais segundo práticas sociais estabelecidas.

Quando pensamos nos papéis sociais desempenhados e aceitos em sala de aula na nossa sociedade, percebemos que o professor goza de autoridade em relação aos alunos e que, por esse motivo, possui o direito de realizar uma maior variedade de atos de fala, como atos de discordância e de desaprovação em relação a determinados comportamentos dos alunos.

Desse modo, falar é desenvolver uma atividade social controlada por regras sociais: cada indivíduo, ao interagir por meio da comunicação, constrói sua relação com o outro. Goffman contribui para a superação da dicotomia falante-ouvinte, colocando em evidência que a participação na interação não é uma tarefa binária, na qual um fala e outro ouve, mas interacional. Nesse sentido, introduz também o conceito de footing (termo em inglês com significado metafórico de 'base relacional') que sublinha a natureza do envolvimento e da participação na interação social. Escreve Goffman (2002):

Uma mudança de footing implica uma mudança no alinhamento que assumimos para nós mesmos e para os outros presentes, expressa na maneira como conduzimos a produção ou a recepção de uma elocução. Uma mudança em nosso footing é um outro modo de falar de uma mudança em nosso enquadre dos eventos ( p. 113).

Segundo essa ideia, existem diversas formas e graus de participação, os falantes podem assumir vários footings interacionais, isto é, vários papéis de participação na interação comunicativa, desempenhando, em certos momentos, o papel de ouvinte e, em outros, o de falante. 
A conversação, portanto, é um tipo particular de interação, em que os atores envolvidos interagem entre si, prestando atenção naquilo que os outros dizem e fazem e, a partir disso, organizam as próprias ações, levando em consideração as ações dos outros participantes. Dessa forma, as interações verbais possuem uma natureza estratégica, isto é, um componente ritual que os falantes colocam constantemente em cena para demonstrar ser atores competentes, ou seja, participantes capazes de reconhecer e respeitar os rituais de interação.

Goffman (2011 [1967]) afirma ainda que cada indivíduo, no decorrer de uma interação, através do próprio comportamento, reivindica uma face, isto é, a máscara que um ator social usa e que varia de acordo com os interlocutores e com o tipo de interação, isto é, uma imagem pública socialmente aprovada que cada indivíduo tem de si e que tenta dar de si próprio.

Durante as interações verbais ocorre um "jogo de faces", no qual cada falante tenta preservar sua própria face e não ameaçar a face do outro. Esses conceitos serão retomados e aprofundados a seguir.

\subsubsection{Penelope Brown \& Stephen Levinson}

Para Brown \& Levinson (1987 [1978]), investigar os princípios do uso da linguagem é descobrir os princípios pelos quais as relações sociais são construídas na interação. Nesse sentido, os autores, alicerçados nas ideias de Goffman (2011 [1967]) e Lakoff (1973), postulam um elaborado instrumento de análise de cortesia verbal que se tornou o modelo mais difundido e que mais influenciou as pesquisas sobre cortesia verbal.

Segundo Brown \& Levinson, cada falante é dotado de duas propriedades especiais: racionalidade e face. A racionalidade do indivíduo é a capacidade de identificar os objetivos comunicativos de um ato intencional e, a partir dele, selecionar os meios adequados para o seu sucesso. Já a face expressa duas necessidades, uma social e outra privada, que são designadas, respectivamente, com os termos face positiva e face negativa.

A face positiva está relacionada ao âmbito social, isto é, a necessidade que cada falante possui de que a própria imagem pública seja reconhecida, aceita, aprovada e valorizada por um grupo social. Já a face negativa relaciona-se ao âmbito individual, ou seja, à necessidade que cada indivíduo possui de que seu espaço não seja violado, de que sua 
liberdade de ação não seja limitada por outro indivíduo; em outros termos, é o desejo de não sofrer imposições. Os autores escrevem:

Central para o nosso modelo é a noção altamente abstracta de face que consiste em dois tipos específicos de desejo (desejo da face) atribuídos por interações entre si: o desejo de ser desimpedido de fazer algo (face negativa) e o desejo (em alguns aspectos) de ser aprovado (face positiva).

[Central to our model is a highly abstract notion of face wich consists of two specific kinds of desire (face-wants) attributed by interactants to one another: the desire to be unimpeded is one's actions (negative face), and the desire (in some respects) to be approved of (positive face)] (BROWN \& LEVINSON, 1987[1978], p. 13)

Faz parte desse conceito a ideia de que, durante a interação social, em geral, e particularmente, durante a interação verbal, os interlocutores respeitem mutuamente os "desejos das faces", que Brown e Levinson chamaram de face-wants. A violação desses desejos ou necessidades causa conflito na interação e as relações pessoais podem ficar negativamente marcadas. Para evitar que se produza essa situação, os interlocutores buscam um equilíbrio, tentando, durante a interação, proteger sua própria face e, ao mesmo tempo, não ameaçar a face do interlocutor.

Os atos de fala que podem colocar em risco a imagem dos participantes durante uma interação, isto é, que podem ameaçar as faces positivas e/ou negativas dos interlocutores foram chamados por Brown \& Levinson (1987 [1978]) de face-threatening acts (FTA), isto é, atos ameaçadores da face. Para os autores, existem determinados tipos de atos, que por sua natureza, ameaçam intrinsecamente a face positiva ou negativa do destinatário e/ou do falante, como críticas, acusações, ofensas etc. A esses atos os autores deram o nome de intrinsic FTAs.

Brown \& Levinson (1987 [1978]) fazem uma distinção entre atos que ameaçam intrinsecamente a face positiva e atos que ameaçam intrinsecamente a face negativa dos interlocutores. Os intrinsic FTAs que ameaçam a face positiva dos interlocutores são:

(i) Aqueles que mostram que $\mathrm{S}$ tem uma avaliação negativa de algum aspecto da face positiva de $\mathrm{H}$ :

(a) expressões de desaprovação, crítica, desprezo ou ridículo, queixas e reprimendas, acusações, insultos ( $\mathrm{S}$ indica que ele não gosta / quer um ou mais desejos de $\mathrm{H}$, atos, características pessoais, bens, crenças ou valores)

(b) contradições ou discordâncias, desafios ( $\mathrm{S}$ indica que ele acha que $\mathrm{H}$ é errado ou equivocado ou irracional sobre algum problema, sendo erroneamente incorreto a desaprovação)

[(i) Those that show that $S$ has a negative evaluation of some aspect of H's positive face: 
(a) expressions of disapproval, criticism, contempt or ridicule, complaints and reprimands, accusations, insults (S indicates that he doesn't like/want one or more of H's wants, acts, personal characteristics, goods, beliefs or values)

(b) contradictions or disagreements, challenges ( $S$ indicates that he thinks $H$ is wrong or misguided or unreasonable about some issue, such wrongness being associated with disapproval)] (p. 66)

Assim podemos perceber que os intrinsic FTAs que ameaçam a face positiva dos interlocutores são atos de fala em que o falante manifesta um julgamento negativo da face positiva do interlocutor, colocando-a em risco, como quando utiliza expressões de desaprovação, crítica, desprezo, reclamações, acusações e insultos.

Já como exemplos de intrinsic FTAs que ameaçam a face negativa dos interlocutores estão:

(i) Os atos que predizem algum ato futuro $\mathrm{A}$ de $\mathrm{H} \mathrm{e}$, assim, colocam alguma pressão sobre $\mathrm{H}$ para fazer (ou abster-se de fazer) o ato A:

(a) ordens e pedidos ( $\mathrm{S}$ indica que ele quer que $\mathrm{H}$ faça, ou se abstenha de fazer, algum ato $\mathrm{A}$ )

(b) sugestões, conselhos ( $\mathrm{S}$ indica que ele pensa que $\mathrm{H}$ deve (talvez) fazer algum ato $\mathrm{A}$ )

(c) lembranças ( $\mathrm{S}$ indica que $\mathrm{H}$ deve se lembrar de fazer algum $\mathrm{A}$ )

(d) ameaças, avisos, ousa ( $\mathrm{S}$ indica que ele ou alguém, ou algo assim, instigará sanções contra $\mathrm{H}$, a menos que ele faça $\mathrm{A}$ )

[(i) Those acts that predicate some future act $A$ of $H$, and in so doing put some pressure on $H$ to do (or refrain from doing) the act $A$ :

(a) orders and requests ( $S$ indicates that he wants $H$ to do, or refrain from doing, some act A)

(b) suggestions, advise ( $S$ indicates that he thinks $H$ ought to (perhaps) do some act $A$ )

(c) remindings ( $S$ indicates that $H$ should remember to do some A)

(d) threats, warnings, dares ( $S$ indicates that he-or someone, or somethingwill instigate sanctions against $H$ unless he does A]) (BROWN \& LEVINSON, 1987 [1978], p. 65-66)

Portanto, os intrinsic FTAs que ameaçam a face negativa dos interlocutores são todos os atos de fala que podem interferir na liberdade do interlocutor, tais como: o ato de ordenar, pedir, sugerir, advertir. Brown e Levinson lembram ainda que alguns atos de fala podem ameaçar intrinsecamente ambas as faces: positiva e negativa.

De acordo com os autores, o grau de ameaça do FTA é sentido pelos falantes com base em três variáveis: distância social entre os interlocutores (Social Distance - D); poder relativo entre os interlocutores (Relative Power - P) e nível de imposição do ato ilocucionário (Absolut Ranking of Imposition - R). 
A distancia social (D) e o poder relativo $(\mathrm{P})$ podem ser entendidos conjuntamente e referem-se à diferença entre os participantes da interação. Se a distância social está relacionada ao grau de familiaridade entre os interlocutores, o poder relativo se refere mais especificamente ao poder que um interlocutor exerce sobre o outro. A relação entre os interlocutores é habitualmente representada da seguinte forma: $(A>B)$ quando o falante possui status superior ao do ouvinte e, por conseguinte, exerce maior poder sobre ele; $(\mathrm{A}<\mathrm{B})$ quando o falante possui status inferior ao do ouvinte e, assim exerce menor poder sobre ele e $(\mathrm{A}=\mathrm{A})$ quando falante e ouvinte possuem igual status social e o mesmo poder relativo.

Em nosso corpus de pesquisa, encontramos relações do tipo $\mathrm{A}>\mathrm{B}$ entre professor $\mathrm{e}$ aluno, pois o status do professor em sala de aula é superior ao do aluno, logo o poder que o professor exerce sobre o aluno também é maior. Consequentemente encontramos $\mathrm{A}<\mathrm{B}$ pois o aluno, ao dirigir-se ao professor, está em condição de inferioridade. Por fim, encontramos também a situação de igualdade de poder relativo $\mathrm{A}=\mathrm{A}$ na interação entre aluno e aluno na sala de aula.

O nível de imposição do ato ilocucionário $(\mathrm{R})$ indica a relação custo-benefício que o ato representa. Quanto maior o benefício proporcionado para o falante pelo proferimento de um ato, maior será seu custo, em termos de escolha e utilização de estratégias linguísticas. Como os atos selecionados para essa pesquisa são discordâncias e desaprovações, supomos que ambos requeiram um certo custo em termos de utilização de estratégias linguísticas, sobretudo de recursos atenuadores.

A fim de evitar ou amenizar os FTAs durante a troca verbal, os interlocutores empregam, de fato, diversas estratégias que permitem o esquivamento do conflito e o estabelecimento ou o reestabelecimento do equilíbrio das relações sociais. Segundo Brown \& Levinson, diante da iminência de efetuar um FTA, o locutor terá duas possibilidades de escolha: produzir ou não o FTA. Se decidir produzi-lo poderá optar por fazê-lo mediante um ato indireto (off-record) ou mediante um ato direto (on-record). Se optar por um ato direto pode escolher ainda, fazê-lo sem ação reparadora, de forma clara e objetiva, sem margem para qualquer tipo de ambiguidade ou com ação reparadora, utilizando estratégias de cortesia negativa ou positiva. As estratégias de cortesia segundo Brown \& Levinson (1987 [1978]) são:

- Cortesia positiva: Tem o objetivo de proteger a fase positiva do ouvinte, evitando colocar em risco sua imagem social positiva. Sugere a existência de um terreno 
comum de interesses e a vontade de ambos os participantes de cooperarem. Compreende várias micro-estratégias, dentre as quais: (1) prestar atenção aos interesses e necessidades do interlocutor; (2) enfatizar os interesses, a aprovação e a simpatia em relação ao interlocutor; (3) utilizar marcadores de identidade do mesmo grupo de pertencimento; (4) procurar o acordo; (5) evitar o desacordo; (6) pressupor; (7) brincar; (8) ser otimista; (9) fazer oferta; (10) assumir ou declarar reciprocidade.

- Cortesia negativa: Tais procedimentos têm o objetivo de salvaguardar a face negativa do ouvinte. É empregada para compensar os atos que ameaçam o reconhecimento e o respeito da liberdade de decisão e de ação do receptor. Os modos de realização são os seguintes: (1) ser indireto; (2) fazer perguntas; (3) colocar limites; (4) ser pessimista; (5) reduzir a imposição, a força do ato; (6) expressar respeito; (7) desculpar-se; (8) impessoalizar locutor e interlocutor (9) não colocar o interlocutor em débito.

Como podemos notar, Brown \& Levinson centraram sua teoria sobre a cortesia nos FTAs, isto é, nos atos ameaçadores da face, porém, Kerbrat-Orecchioni (2006 [1996]) salienta que essa é uma concepção extremamente pessimista da interação, representando que os indivíduos em sociedade estão sob a ameaça permanente de FTAs. A autora critica o fato de Brown \& Levinson reduzirem a cortesia à sua forma pessimista e não levarem em consideração que, na interação verbal, estão presentes, não somente FTAs, mas também, atos que valorizam a face, como o elogio e o agradecimento. E para explicá-los, KerbratOrecchioni sugere um modelo teórico suplementar que considere, de alguma forma, o lado positivo dos atos de fala e nomeou esses atos de FFAs (Face Flattering Acts), isto é, atos valorizadores da face.

Posto isso, como os atos de fala da discordância e da desaprovação que analisaremos relacionam-se aos FTAs e não aos FFAs, usaremos como referência para entendê-los o modelo de Brown \& Levinson. Para os autores, o falante pode suavizar os efeitos dos atos ameaçadores da face, recorrendo a procedimentos que denominaram de atenuadores (softners). Nesse sentido, quanto mais ameaçador for um FTA, mais estratégias atenuadoras serão necessárias para suavizar a força do enunciado. Aprofundaremos melhor essa ideia na parte 1.5 dedicada à atenuação. 


\subsubsection{Outros autores}

A noção da universalidade da teoria da cortesia proposta por Brown \& Levinson foi bastante questionada pelos pesquisadores que os sucederam. Bruce Fraser e Willian Nolen (1981), por exemplo, se opõem à visão de cortesia como estudo de atos de fala isolados e propõem uma abordagem de cortesia dependente do contexto comunicativo e social.

Os autores afirmam que a cortesia verbal reside essencialmente numa espécie de contrato conversacional. Um acordo tácito de direitos e de obrigações mútuas entre as pessoas envolvidas numa conversação que não são estabelecidos universalmente, podendo, portanto, variar de uma cultura a outra. De acordo com a natureza da conversação, o contrato fundamenta-se em direitos e obrigações específicas. Fraser (1980) menciona o exemplo de uma consulta médica. Ao entrar no consultório, o paciente reconhece, implicitamente, ao médico o direito de lhe fazer perguntas sobre sua vida e hábitos. Fato que não acontece, por exemplo, durante uma prova oral na faculdade, pois ao examinador não é conferido o direito de fazer perguntas sobre a vida particular do estudante, devendo ele limitar-se a fazer perguntas que verifiquem o grau de conhecimento do estudante sobre um determinado assunto acadêmico. Dessa forma, Fraser (1980), estabelecendo uma relação intrínseca entre contrato conversacional e cortesia verbal, define essa última da seguinte forma:

Dada essa noção de contrato conversacional, podemos dizer que um enunciado é cortês, na medida em que, o falante, na opinião do ouvinte, não violou os direitos ou obrigações que estão em vigor naquele momento.

[Given this notion of the conversational contract, we can say that an utterance is polite, to the extent to which the speaker, in the hearer's opinion, has not violated the rights or obligations which are in effect at that moment.] (p. 343-344)

Assim, a noção de contrato conversacional determina os direitos ou as obrigações que não podem ser violadas no momento da troca comunicativa, pois, uma vez violadas, a comunicação deixa de ser cortês. Note-se, no entanto, que as normas de cortesia determinam o estilo da interação verbal, mas não afetam o conteúdo proposicional daquilo que se comunica.

$\mathrm{Na}$ visão de Fraser e Nolen, trata-se de regras que regulam e não que formam o comportamento humano, isto é, não são regras constitutivas da comunicação como a gramática, por exemplo, sem a qual seria impossível comunicar, mas são regras que se referem ao estilo de comunicar. Logo, não são as expressões linguísticas em si que devem ser 
consideradas corteses ou descorteses, mas as condições nas quais essas expressões são utilizadas que determinam um julgamento negativo ou positivo do comportamento linguístico de um falante. Dessa forma, Fraser e Nolen introduzem um elemento novo nos estudos da cortesia: o contexto.

Blum-Kulka (1992), analisando a cortesia dentro da sociedade israelense, constata que os princípios de cortesia não são universais ${ }^{6}$, como acreditavam Brown \& Levinson (1987[1978]), mas são determinados culturalmente. Dessa maneira, a cortesia é um comportamento que pode ser definido como socialmente apropriado com base nas expectativas e normas culturais. Como afirma a autora, os sistemas de cortesia demonstram uma interpretação culturalmente filtrada pela interação por meio de quatro parâmetros essenciais: motivações sociais, modos de expressão, diferenciais sociais e significados sociais. As noções culturais interferem no determinar as características distintivas de cada um dos quatro parâmetros e, consequentemente influenciam de forma significativa na compreensão social da cortesia dentro de cada sociedade no mundo (BLUM-KULKA, 1992, p. 270).

Se as normas de cortesia são culturalmente determinadas, a cortesia então é uma competência que se adquire através do processo de socialização e os dados que a configuram dependem da exposição do indivíduo às convenções de um ambiente culturalmente determinado e composto por diversos tipos de interação. Um comportamento adequado é consequência do domínio dos princípios e parâmetros de categorização social que operam na cultura. Se a comunicação se produz entre membros de uma mesma cultura, a ruptura das regras é percebida como falta de educação, já se a ruptura acontece entre membros de diferentes culturas, normalmente, se forma um estereótipo cultural (MARIOTTINI, 2007, p. 44).

Assim, a cortesia como conceito é universal, pois em todas as sociedades humanas existem comportamentos que permitem manter a harmonia durante as trocas conversacionais, porém cada cultura possui suas normas de aplicação da cortesia. Segundo Haverkate: "nenhum falante, independente da sua língua materna, é capaz de se expressar de forma neutra: suas locuções são corteses ou não são, o que equivale a afirmar que a cortesia está presente ou está ausente; não existe meio termo". [ningún hablante, cualquiera que sea su lengua materna, es capaz de expresarse de forma neutra: sus locuciones son corteses o no lo

\footnotetext{
${ }^{6}$ Sobre a polêmica da universalidade do modelo de cortesia proposto por Brown e Levinson indicamos a leitura de BROWN, Penelope (2015). Politeness and Language. International Encyclopedia of the Social \& Behavioral Sciences, 2nd edition, Volume 18.
} 
son, lo cual equivale a afirmar que la cortesia está presente o está ausente; no hay término medio.] (HAVERKATE, 1994, p. 17).

Como podemos notar, estudar o fenômeno da cortesia é considerar um princípio universal e uma realização particular dentro de cada cultura. É respeitar regras de um contrato conversacional dentro de um contexto específico de interação. Tentando abranger os vários aspectos e as particularidades envolvidas no conceito de cortesia, nasce a perspectiva da Pragmática sociocultural, que estuda as características dos participantes da troca verbal, a descrição da situação comunicativa, a análise da interação e as variáveis sociais que influenciam as escolhas linguísticas.

Como representante dessa perspectiva, Diana Bravo (2005) afirma que o pesquisador, para poder descrever os comportamentos sociais dos falantes de uma língua, deve conhecer e, possivelmente, compartilhar os contextos socioculturais, deve saber quando uma ação é uma ameaça direta, implícita ou atenuada, quando é ou não cortês.

Briz (1995, 1998, 2003, 2013) e o grupo VAL.ES.CO (Valencia Español Coloquial) dedicam-se à análise da cortesia em língua espanhola. O objetivo do grupo é identificar as convenções sociais segundo as quais um comportamento linguístico pode ser considerado cortês ou descortês dentro de uma interação particular. A partir disso, os pesquisadores focam suas análises na utilização da atenuação linguística, uma vez que a cortesia é um princípio que rege socialmente as interações e a atenuação é parte constituinte desse princípio, isto é, da cortesia.

Em seguida, apresentaremos de forma mais detalhada o que é a atenuação, quais são seus objetivos e seus efeitos na interação.

\subsection{ATENUAÇÃO}

Como vimos anteriormente, a cortesia verbal poder ser definida como um conjunto de normas sociais, estabelecidas por cada sociedade, que regulam o comportamento adequado de cada membro dentro dessa sociedade (ESCANDELL VIDAL, 1996). Nesse sentido, quando falamos de cortesia verbal, estamos nos referindo às normas de comportamento que regulam a interação verbal e, dentre essas normas que possuem a função de manter o equilíbrio interacional, encontramos a atenuação. 
Briz \& Albelda (2013) fazem uma distinção entre cortesia e atenuação. Para os autores, a atenuação é um dos princípios constituintes da cortesia verbal, mas não é o único. Desse modo, cortesia e atenuação não devem ser confundidas, porque, se ser atenuado representasse ser cortês, não o ser significaria ser descortês, o que não é verdadeiro. Assim, a atenuação é entendida pelos autores como um recurso integrante da cortesia verbal, diretamente relacionada à eficácia da atividade argumentativa e ao equilíbrio conversacional e relacional entre os participantes de uma conversação. Em outras palavras, a atenuação é um recurso utilizado pelos seres humanos com o objetivo de favorecer as relações pessoais. Os autores escrevem:

\begin{abstract}
A atenuação é uma atividade argumentativa (retórica) estratégica de minimização da força ilocucionária e do papel dos participantes na enunciação para alcançar com êxito o objetivo pretendido e que é usado em contextos situacionais de menor imediatismo, que exigem ou que desejam apresentar menor imediatismo comunicativo.

[La atenuación es una actividad argumentativa (retórica) estratégica de minimización de la fuerza ilocutiva y del papel de los participantes en la enunciación para lograr llegar con éxito a la meta prevista, y que es utilizada en contextos situacionales de menos inmediatez o que requieren o se desea presenten menos inmediatez comunicativa.] (BRIZ \& ALBELDA, 2013, p. 292)
\end{abstract}

Dessa maneira, a atenuação é definida como um mecanismo estratégico tático (intencional), relacionado à eficácia do discurso e como um mecanismo estratégico retórico, porque pretende persuadir e convencer o interlocutor, enquanto procura preservar as relações interpessoais e sociais. Portanto, a atenuação é o resultado de mecanismos presentes na comunicação que atuam para provocar determinados efeitos no discurso e na relação pessoal entre os interlocutores.

Para Caffi, com os termos atenuação ou mitigação ou downgrading, nomeia-se um conjunto de estratégias enraizadas em uma consciência metapragmática pela qual as pessoas tentam fazer algo, de modo eficaz, por meio do dizer. A autora afirma: "De acordo com a minha definição, a mitigação - que eu considero um sinônimo de downgrading - é o resultado de um enfraquecimento de um dos parâmetros interacionais [...]" [According to my definition, mitigation - which I take to be a synonym for downgrading - is the result of a weakening of one of the interactional parameters (...)] (CAFFI, 1999, p. 882).

A atenuação, segundo Caffi (1999), age em forma de multicamadas e de maneira multidimensional, afetando simultaneamente uma pluralidade de níveis linguísticos e 
dimensões interacionais. Com sua utilização, é possível obter diversos graus de distanciamento da mensagem e, ao mesmo tempo, alcançar diversos níveis de aproximação entre os interlocutores. O falante que escolhe enfraquecer a força ilocucionária do seu ato de fala, pode ter, como objetivo, criar um distanciamento da sua mensagem, para aproximar-se social e afetivamente do interlocutor. Nesse sentido, Briz \& Albelda (2013) afirmam que atenuar linguisticamente significa distância, enquanto socialmente significa aproximação.

Em relação ao fator linguístico, segundo Briz (1995, 1998, 2003, 2013), a atenuação pode ser identificada tanto no nível do dito quanto no nível do dizer. A atenuação do dito ou do conteúdo proposicional é aquela que ocorre principalmente por meio de recursos morfológicos ou através de uma seleção lexical, como são exemplos os casos de eufemismos e lítotes. A atenuação do dito atenua também, indiretamente, o nível do dizer e pode ser identificada pela suavização de uma quantidade ou pela imprecisão de um elemento da proposição. Caffi (1999) classificou esse tipo de atenuação do dito de atenuação interna e a atenuação do dizer de atenuação externa.

A atenuação do dizer ou da força ilocucionária parte da classificação dos atos de fala de Searle e pode afetar os atos diretivos, assertivos, comissivos e expressivos. Albelda (2010) realizou um estudo sobre os procedimentos atenuadores mais frequentes em cada tipo de ato. Segundo a autora, dentro dos atos diretivos, é conveniente distinguir aqueles que se realizam em benefício do falante, como ordens, perguntas, proibições, daqueles que se realizam em benefício do interlocutor, como os conselhos, por exemplo. Albelda afirma que, no caso dos diretivos em benefício do ouvinte, é menos frequente a utilização de procedimentos atenuadores e que, nos diretivos em benefício do falante, os recursos utilizados são os mais diversos possíveis como: conjugar os verbos na forma condicional ou no imperfeito; utilizar verbos e advérbios modais como: poder, querer; fazer uso de formas estereotipadas condicionais ou concessivas como: se não for te incomodar, se não se importa; perguntas indiretas etc.

Com relação aos atos assertivos, Albelda afirma que a principal estratégia atenuadora consiste em amenizar ou evitar a responsabilidade do falante em relação ao que diz. Ocorre uma redução da força ilocucionária da asserção, mediante a utilização de expressões de dúvida ou de possibilidade, ou ainda, oculta-se o sujeito recorrendo a formas impessoais de verbos. São exemplos a utilização de verbos como: supor, crer, pensar, imaginar e de expressões como para mim, na minha opinião, a meu modo de ver etc; utilização de modalizadores como: talvez, quiçá, seguramente, provavelmente, etc; 
apagamento da origem do dêitico com a utilização das seguintes expressões: pelo que dizem, segundo comentam, pelo visto, ao que parece; a utilização da forma se e de outras formas impessoais; evitar a referência direta ao próprio falante como origem de uma opinião ou de um julgamento, como em: "Temo que devo ir acabando a sessão".

Os atos de fala comissivos e expressivos também são suscetíveis à atenuação, mas segundo Albelda (2010), a experiência sobre a análise de corpus e a literatura a eles dedicada é escassa e indica que a atenuação é menos frequente. Os comissivos - relembra a autora - são atos de fala que indicam o comprometimento do falante em atuar conforme sua enunciação, se ele atenua sua fala, então, expressará um menor compromisso com suas propostas. Já os atos expressivos só são atenuados quando está em jogo a imagem do interlocutor. São, por exemplo: os insultos, as recriminações, as queixas, etc.

Como a atenuação é um fenômeno pragmático, sua realização está condicionada a um contexto real de enunciação. Segundo Albelda (2010), os problemas fundamentais do reconhecimento dos atenuadores em um corpus derivam do fato de que uma mesma forma linguística (morfológica, sintática, semântica, modal) pode desempenhar ou não uma função atenuadora, segundo o uso concreto. Assim, para determinar a atenuação, é necessário levar em consideração o contexto geral e o contexto interacional específico. Segundo Briz e Albelda (2013), existem situações que favorecem o uso da atenuação, como as situações de menor imediatismo comunicativo e de maior formalidade.

Para identificar a forma atenuadora dentro do contexto interacional concreto, é imprescindível identificar o segmento causador ou desencadeador (o gatilho que favorece ou provoca a atenuação), que pode ser o próprio contexto compartilhado pelos interlocutores e não explícito na interação ou a reação de um dos falantes durante a troca comunicativa; $o$ segmento atenuador (o elemento linguístico que atenua); e o segmento atenuado (parte do discurso que é afetada pelo elemento atenuador, ou seja, a ação e a intenção que convém atenuar). Os autores afirmam que, em algumas ocasiões, o segmento atenuado coincide com o segmento causador ou desencadeador.

É ainda essencial levar em conta que a atenuação pode ser utilizada com três objetivos:

I) Autoproteção, quando o falante pretende velar por si mesmo, evitando ou reduzindo o compromisso dele próprio com o enunciado, porque afeta ou pode afetar a sua própria imagem; 
II) Prevenção, quando a intenção é prevenir uma possível ameaça a imagem do outro, uma invasão no seu espaço, um possível obstáculo ao alcance de uma meta ou para evitar tensões e conflitos (proteção do "eu" e do "tu");

III) Reparação, quando o objetivo é reparar uma ameaça a imagem do outro ou uma intromissão no território alheio (salvaguarda do "eu e do "tu") (BRIZ \& ALBELDA, 2013, p. 302-303).

Para os autores, a utilização da atenuação só pode ser considerada cortês quando ela exerce a função de prevenção e/ ou de reparação de conflito durante a interação. Quando é usada com a função de autoproteção não existe cortesia, uma vez que a cortesia é uma norma social fundamentada na relação com o outro. Assim, quando o falante se auto-protege na interação, por meio da atenuação, seu objetivo não é evitar o conflito relacional e, sim, reduzir seu compromisso com sua enunciação.

São várias as táticas ou procedimentos atenuadores à disposição dos interlocutores para que eles possam atingir seus objetivos comunicativos. Tais procedimentos constituem-se de um conjunto de artifícios usados para diminuir a força ilocucionária de um enunciado e, assim, preservar a face do locutor e do interlocutor e podem ser de natureza verbal, paraverbal (tom da voz, marcas de hesitação etc.) e não verbal (sorriso, inclinação da cabeça etc.). Em nossa pesquisa, nos concentraremos nos atenuadores verbais e apontaremos, quando necessário, a presença dos atenuadores não verbais e paraverbais, sem fazer, porém uma análise aprofundada desses elementos.

Como foi dito anteriormente, cada cultura possui um jeito próprio de conceber o mundo e de estabelecer as relações entre os indivíduos. Nesse sentido, cada cultura se apropria da atenuação também à sua maneira e desenvolve procedimentos ou recursos atenuadores reconhecidos e aceitos dentro daquela sociedade.

Além disso, Caffi (1999), concordando com Blum-Kulka (1992), afirma que a mitigação envolve aspectos psicológicos e emotivos que, até o momento, foram negligenciados em favor dos aspectos sociolinguísticos. A autora afirma ainda que essa é uma questão crucial, pois a gestão da distância psicológica é parte integrante de nossa competência comunicativa, tanto nos processos de codificação como de decodificação, o que confirma, por sua vez, como o afeto e a comunicação emotiva estão integradas no nosso modo de agir com a linguagem.

Além disso, Caffi (2009) ressalta que nossas escolhas linguísticas constroem nossa identidade. A autora escreve: 
eu falante, dependendo de como dou uma ordem, por exemplo, não apenas procuro a melhor maneira de alcançar o meu objetivo, a execução dessa ordem por parte do meu destinatário, mas me construo como uma pessoa de um tipo ou de outro. Por exemplo, como alguém que pede as coisas gentilmente, ou como uma pessoa autoritária. Isso quer dizer que, com o meu discurso, eu me construo como enunciador que tem não somente uma face, mas também tem um self, um eu, que é construído exatamente pelo tipo de discurso posto em prática e por suas características estilísticas.

[io parlante, a seconda di come ad esempio do quell'ordine, non soltanto cerco il modo migliore per raggiungere il mio scopo, l'esecuzione di quell'ordine da parte del mio destinatario, ma mi costruisco anche come persona di un tipo o dell'altro. Ad esempio, come qualcuno che richiede delle cose gentilmente, piuttosto che come una persona autoritaria. Vale a dire, con il mio discorso, mi costruisco come enunciatore che ha non soltanto una faccia, ma ha anche un self, un sé, che viene costruito appunto dal tipo di discorso messo in atto e dalle sue caratteristiche stilistiche.] (p. 126)

Desse modo, quando estudamos a cortesia verbal e a utilização dos atenuadores na fala, devemos ter em mente a confluência de aspectos interacionais e relacionais que eles revelam, pois, se linguisticamente a atenuação pode distanciar o falante da sua enunciação, emotivamente pode criar uma relação pessoal de aproximação.

No nosso contexto de pesquisa, por exemplo, a atenuação na relação professor-aluno reflete, algumas vezes, a cooperatividade entre os falantes, enquanto, outras vezes, é superada a favor do objetivo imediato e decisivo da interação. Na relação assimétrica professor-aluno, existe, muitas vezes, uma tensão entre o comportamento do aluno esperado pelo professor e o comportamento que o aluno, de fato, assume em sala de aula. Os professores, muitas vezes, invadem o território dos alunos, impondo obrigações e proibições (participar da aula fazendo as atividades propostas; não falar ao mesmo tempo que o professor está falando etc) e os alunos, frequentemente, devem optar por abrir mão dos seus desejos imediatos em prol do bom funcionamento da aula e de um bom relacionamento com o professor. Nesse sentido, a utilização da atenuação pode favorecer emocionalmente e psicologicamente a interação e a relação em sala de aula e, por conseguinte o ensino e aprendizagem.

Assim, para Caffi (1999), a análise pragmática não pode ser esgotada somente pelo estudo estrutural sequencial dos tipos de atividades, mas deve ser integrada num estudo estilístico centrado na construção dessas identidades (provisórias) sociais e psicológicas. Segundo a autora, o que é crucial nessa perspectiva não é a psicologia individual, mas sim as ligações entre variáveis interdependentes (variáveis psicológicas, sociológicas e linguísticas) 
dentro do contexto de interação. Uma teoria pragmática deve considerar todas essas variáveis juntas: uma abordagem sistêmica geral torna possível fazer perguntas como: de que forma as escolhas estilísticas de superfície podem contribuir para a construção da relação interpessoal? (CAFFI,1999, p. 888).

Em nossa pesquisa, além de verificarmos a utilização de procedimentos atenuadores nos atos de discordância e desaprovação, produzidos por crianças bilíngues e por suas professoras, durante a interação em sala de aula, procuramos identificar quais efeitos produzem na relação pessoal em sala de aula e evidenciamos possíveis analogias e diferenças na escolha dos procedimentos atenuadores em língua portuguesa e língua italiana.

\subsection{DISCORDÂNCIA E DESAPROVAÇÃO: CARACTERIZAÇÃO}

Retomando a teoria de Austin (2012 [1962]), cada ato de fala pode ser decomposto em ato locucionário (ato de dizer alguma coisa), ato ilocucionário (corresponde a ação que é executada ao proferir o ato) e ato perlocucionário (efeito ou consequência da ação de dizer dentro de um determinado contexto) e possui uma força ilocucionária (de uma discordância ou desaprovação, por exemplo).

Em nossa pesquisa investigaremos, por meio das teorias dos atos de fala (Austin e Searle), da teoria da cortesia (Brown \& Levinson) e da teoria da atenuação (Briz \& Albelda), a realização e os efeitos de dois atos de fala: a discordância e a desaprovação dentro do contexto escolar. Para isso, iniciaremos definindo esses dois atos com base nas teorias de Austin e Searle.

A fim de termos um ponto de partida para a caracterização dos atos de fala de discordância e de desaprovação, fomos, primeiramente, procurar a definição dos termos discordar e desaprovar no dicionário da língua portuguesa Houaiss (2004). Segundo esse dicionário, o termo discordar significa ter opinião contrária, divergir, logo, o ato de discordância se relaciona ao campo do saber, uma vez que a opinião reflete um ponto de vista do falante, formado a partir de seus conhecimentos (saberes). Já o termo desaprovar é definido como a ação de não considerar bom, justo, adequado e é sinônimo de reprovar, logo, o ato de desaprovação se relaciona ao campo do fazer, uma vez que o falante realiza uma censura de algo que não considera bom. Dito de outra maneira, quando um falante não 
concorda com uma determinada opinião ele discorda, mas quando o falante não concorda com um determinado tipo de comportamento, o desaprova.

Assim sendo, para expressar uma desaprovação, estão presentes atos que Austin classificou como vereditivos, uma vez que se relacionam com o juízo da verdade. No caso da desaprovação, está explícito o julgamento negativo que o falante realiza em relação a um determinado comportamento do interlocutor, que pode ter infringido, na opinião do falante, alguma norma de conduta da comunidade da qual fazem parte.

Ao mesmo tempo, estão presentes atos de fala que Austin classificou como exercitivos e Searle como diretivos, isto é, atos que se relacionam com o exercício do poder. Para Searle, os diretivos exprimem a vontade da parte do falante de induzir o interlocutor a executar ações futuras. Dessa forma, ao desaprovar um comportamento, o falante implicitamente deseja e encoraja o interlocutor a mudar de atitude. Em outras palavras, quando um falante desaprova uma atitude do seu interlocutor, exerce sobre ele um julgamento e, ao mesmo tempo, influencia o seu comportamento futuro, na direção do que o falante julga ser o correto.

Nesse sentido ainda, podem estar presentes atos expositivos (segundo a classificação de Austin) e assertivos (na classificação de Searle) que se relacionam à exposição dos próprios argumentos, pois o falante pode tentar convencer o interlocutor explicando ou demonstrando porque sua possível mudança de atitude seria desejável e adequada.

Além disso, ao desaprovar, o falante também está realizando um ato comportamental, na classificação de Austin, e expressivo, na classificação de Searle, uma vez que ambas as classificações estão relacionadas com as normas de conduta social. Tais normas estabelecem o que é aceito, desejável e esperado socialmente dos falantes dentro de uma determinada comunidade linguística. No caso da desaprovação, está implícita a ideia: "não se comporte assim", "isso não é aceito nesse contexto". Não concordamos com Searle que a direção de adequação das palavras seja nula, uma vez que o(s) contexto(s) interacional(is) e social(is) agem sobre os indivíduos influenciando suas enunciações e estas, por sua vez, influenciarão novamente o indivíduo, interferindo no seu modo de relacionar-se com e no mundo.

Dessa forma, podemos sintentizar as carcaterísticas do ato de desaprovação da seguinte forma: 


\section{DESAPROVAÇÃ̃O}

\begin{tabular}{|l|l|}
\hline Austin & Searle \\
\hline Ato vereditivo & ---------------------- \\
\hline Ato exercitivo & Ato diretivo \\
\hline Ato expositivo & Ato assertivo \\
\hline Ato comportamental & Ato expressivo \\
\hline
\end{tabular}

Quadro 1 - Características do ato de desaprovação

Em relação à cortesia verbal e ao conceito sobre face de Goffman, retomado e reelaborado por Brown \& Levinson, que versa sobre a necessidade que cada indivíduo possui de ser socialmente aceito e valorizado (desejo da face positiva) e de não ter sua liberdade de ação violada (desejo da face negativa), Brown \& Levinson percebem que existem atos de fala que ferem intrinsecamente esses desejos, são os ditos intrinsic FTAs e, como os autores já apontaram, expressões de desaprovação (expressions of disapproval) são atos que por si só ameaçam a face positiva dos interlocutores.

Percebemos que o ato de desaprovar se relaciona diretamente com o julgamento de uma conduta social e que, portanto, coloca em risco a face positiva do interlocutor, porque, como afirmado anteriormente, emite um juízo negativo da sua imagem social, mas acreditamos, também, que o ato de desaprovar, coloca em risco, ao mesmo tempo, a face negativa do interlocutor, pois interfere na sua liberdade de escolha.

Sobre os procedimentos de atenuação, geralmente presentes nesse tipo de ato, vimos com Albelda (2010) que, por apresentar simultaneamente as características dos atos que Searle classificou como diretivos, assertivos e expressivos, pode ser encontrada uma grande variedade de procedimentos atenuadores.

Já na discordância, estão presentes também atos que Austin classificou como vereditivos, ou seja, atos que se relacionam com o julgamento de uma enunciação com base em uma crença. O falante, quando discorda de algo, emite uma opinião com base em seus conhecimentos sobre o tema, isto é, no que ele acredita ser verdadeiro e realiza, assim, uma avaliação.

A discordância pode ser realizada também por atos expositivos, segundo a classificação de Austin, e assertivos ou representativos, na classificação de Searle, já que, durante uma argumentação na qual o falante busca explicar para o seu interlocutor as causas ou os motivos de sua discordância, cumpre um ato em relação à verdade. Mais uma vez, não concordamos com Searle quando ele afirma que a direção de adequação vai das palavras ao 
mundo, porque, como vimos anteriormente, a direção da enunciação é dupla, isto é, do contexto para o indivíduo e do indivíduo para o contexto.

Dessa forma, com base na classificação de Austin e Searle a discordância pode ser caracterizada da seguinte forma:

\section{DISCORDÂNCIA}

\begin{tabular}{|l|l|}
\hline Austin & Searle \\
\hline Ato vereditivo & ------------- \\
\hline Ato expositivo & Ato assertivo \\
\hline
\end{tabular}

Quadro 2 - Características do ato de discordância

Em relação à necessidade que cada indivíduo possui de ser socialmente aceito e valorizado (desejo da face positiva), os atos de discordância (disagreementes), como já assinalaram Brown \& Levinson (1987 [1978]), são atos intrinsecamente ameaçadores da face positiva do interlocutor, pois, ao discordar do interlocutor, o falante julga como incorreta uma determinada opinião. Em relação à face negativa, acreditamos que o ato de discordar não ameace a face negativa do interlocutor como o ato de desaprovar, pois, ao discordar, o falante não exige do interlocutor nenhuma mudança de convicção, embora esteja explícito que o falante considera a opinião do interlocutor incorreta. 


\section{METODOLOGIA DA PESQUISA}

Neste capítulo, serão apresentadas as características da pesquisa qualitativa de abordagem etnográfica e do estudo de caso; a caracterização do contexto no qual se realizou a pesquisa; a descrição dos participantes da pesquisa; os procedimentos e os instrumentos usados na coleta de dados e os procedimentos de análise.

\subsection{PESQUISA QUALITATIVA: ABORDAGEM ETNOGRÁFICA E ESTUDO DE CASO}

A Pragmática não é uma perspectiva com uma metodologia própria e bem definida, com objetivos e instrumentos de análise delimitados e universalmente reconhecidos. Por essa razão, boa parte dos estudos pragmáticos empíricos se caracteriza pelo uso de um método aglutinante, que engloba vários aspectos provenientes de diferentes abordagens científicas. A dispersão metodológica pode ser devida fundamentalmente à natureza simbiótica dos estudos pragmáticos, isto é, ao seu caráter integrador e interdisciplinar. Desse modo, cada disciplina contribui oferecendo ao analista uma perspectiva que melhor se adapte ao seu objetivo de análise (MARIOTTINI, 2007).

Partindo do pressuposto que os estudos sob o viés da Pragmática envolvem o conhecimento sobre o contexto (ou a realidade) da situação comunicativa e que, por esse motivo, abrangem muitas variáveis, as pesquisas da área são, normalmente, qualitativas. Existem também pesquisas quantitativas, que, na maioria das vezes, se relacionam, no entanto, com as pesquisas de tipo qualitativo. A pesquisa qualitativa objetiva compreender a realidade considerando-a como uma construção do ser humano, focalizando o processo e o significado que os participantes atribuem aos fatos. Como afirmam Ludke e Andre (1986), isso pressupõe que qualquer atividade científica de observação "traz consigo, inevitavelmente, a carga de valores, preferências, interesses e princípios que orientam o pesquisador" (p. 03).

De acordo com as autoras, as pesquisas qualitativas têm como características gerais cinco pontos básicos: a-) o ambiente natural é a fonte direta de dados; b-) os dados coletados são predominantemente descritivos; c-) a preocupação em observar o processo é muito maior do que com o produto final; d-) os significados que as pessoas dão às coisas e à sua vida são focos de atenção especial para pesquisador; e-) a análise dos dados tende a seguir um processo 
indutivo, isto é, após, considerar um número suficiente de casos particulares, conclui-se uma verdade ou uma tendência geral. A indução, ao contrário da dedução, parte da observação de dados particulares da experiência sensível. A partir dessas características gerais, a pesquisa qualitativa pode assumir diversas formas, dentre as quais, a de tipo etnográfico e o estudo de caso.

A etnografia é a descrição de um sistema de significados culturais de um determinado grupo. Assim, segundo Ludke e Andre (1986), a etnografia configura-se como ciência da descrição cultural e apresenta duas hipóteses básicas sobre o comportamento humano: a-) uma hipótese naturalística ecológica que afirma ser o comportamento humano significativamente influenciado pelo contexto em que se situa e, b-) uma hipótese qualitativofenomenológica que busca entender o comportamento humano dentro do quadro referencial que o configura, ou seja, dentro do contexto que molda os pensamentos, os sentimentos, as interpretações e as ações humanas.

Quanto ao método da pesquisa etnográfica, não existe um em particular, no entanto, podemos dizer que nossa pesquisa se enquadra em um tipo de pesquisa etnometodológica, uma vez que busca descrever e analisar um determinado tipo de interação dentro de um determinado contexto, no qual indivíduos constroem juntos, negociando por meio de vários instrumentos, um sentido para o seu agir comunicativo.

A etnometodologia nasce nos Estados Unidos, na década de 1960. É uma vertente da micro-sociologia e seus principais expoentes são Harold Garfinkel, Aaron Cicourel e Harvey Sacks. Esses estudiosos partem da ideia que os membros de um grupo social utilizam métodos para desenvolverem suas atividades cotidianas e práticas, inclusive a comunicação. A etnometodologia, portanto, estuda esses métodos, nos quais a realidade social é continuamente criada pelos indivíduos, não constituindo-se a partir de um fato preexistente.

Segundo Ludke e Andre (1986), a observação constitui um dos principais instrumentos de coleta de dados nas abordagens qualitativas, pois a experiência direta é o melhor teste de verificação da ocorrência de um determinado assunto. Como a Pragmática se ocupa da dinamicidade da linguagem no agir social, nossa forma de investigar os fenômenos está condicionada à observação e à busca de regularidades significativas a partir de inferências que possam ser legitimadas pelo contexto. O objeto de estudo da Pragmática é o agir comunicativo em situação e não em abstrato, por essa razão, se pauta principalmente na observação dos fatos e requer uma epistemologia de análise muito flexível. Nesse sentido, 
para que possamos analisar a construção das relações pessoais por meio da linguagem, considerando a complexidade do processo, optamos por realizar um estudo de caso.

Os estudos de caso, segundo Ludke e Andre (1986), buscam retratar a realidade de forma completa procurando evidenciar a multiplicidade de dimensões presentes numa determinada situação. Possuem um campo de trabalho mais específico, isto é, o caso se destaca por constituir uma unidade dentro de um sistema mais amplo. Os estudos de caso, ainda segundo as autoras, enfatizam a interpretação em contexto, ou seja, para compreender melhor a manifestação geral de um problema, ações, percepções, comportamentos e interações das pessoas devem ser relacionadas à situação específica onde ocorrem. Os estudos de caso podem ser qualitativos ou não, mas alguns cuidados devem ser tomados, pois, por tratar-se de um estudo de um fenômeno bem delimitado, é essencial evitar afirmações generalizadoras.

Desse modo, nossa pesquisa configura-se como uma pesquisa de tipo qualitativo, pois considera a realidade como uma construção do ser humano. É uma pesquisa de cunho etnográfico, porque leva em consideração o sistema de significados culturais de duas sociedades, a brasileira e a italiana, e é também um estudo de caso, pois, por meio da delimitação de um contexto específico, busca retratar a realidade de forma completa, procurando evidenciar a multiplicidade de dimensões presentes numa determinada situação.

\subsection{CONTEXTO EDUCACIONAL DA PESQUISA: SCUOLA ITALIANA EUGENIO MONTALE}

A pesquisa foi realizada na Scuola Italiana Eugenio Montale, localizada no bairro do Morumbi, na zona sul de São Paulo, capital. A instituição de ensino particular foi fundada em 1982, por um grupo de pais italianos empenhados em uma proposta pedagógica de base

filosófica e humanista. Segundo informações do site da escola (disponível em: <www.montale.com.br>, último acesso em: 13/10/2017), o objetivo da instituição é promover uma escolarização que favoreça a construção da autonomia, pautada em três saberes: o saber como apropriação do conhecimento, organizado nos principais campos teóricos relacionados à cultura literária, histórica, científica e artística; o saber fazer que é a capacidade de manejar e aplicar os conhecimentos em novas situações e o saber ser que se relaciona à postura ética do cidadão na vida social. 
Além disso, a escola destaca que proporciona um ambiente multicultural e diversificado, de acordo com as exigências atuais de uma escola internacional. É a única do Estado de São Paulo a ser reconhecida como "scuola paritaria" pelo Governo Italiano, fato que garante o acesso direto dos alunos em escolas e universidades europeias, bem como em escolas e universidades brasileiras.

As salas de aulas possuem número reduzido de alunos e a grade curricular da Escola contempla, desde o primeiro ano do Ensino Fundamental I, a aprendizagem da Língua Italiana, Língua Portuguesa, Língua Inglesa (a partir do $3^{\circ}$ ano), Matemática, História Geral e do Brasil, Geografia Geral e do Brasil, Música, Educação Física, Ciências Naturais e Artes Visuais. As disciplinas são ministradas em um dos dois idiomas, sendo que há uma prevalência da Língua Italiana. As aulas são em período integral (das 8 h00 às 15h30) para os alunos do Ensino Fundamental e do Ensino Médio. Os alunos da Educação Infantil podem optar pelo meio período.

Nossa pesquisa realizou-se com os alunos do $5^{\circ}$ ano do Ensino Fundamental I. A carga horária referente a cada disciplina para o $5^{\circ}$ ano pode ser observada na seguinte imagem retirada do site da Escola:

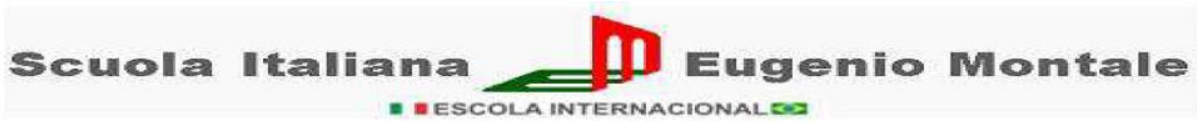

Grade Curricular - Ensino Fundamental I

\begin{tabular}{|c|c|c|c|c|c|}
\hline \multirow[t]{2}{*}{ DISCIPLINAS } & \multicolumn{5}{|c|}{ ANOS } \\
\hline & $1^{\circ}$ & $2^{\circ}$ & $3^{\circ}$ & $4^{\circ}$ & $5^{\circ}$ \\
\hline Língua Italiana & 7 & 7 & 5 & 5 & 5 \\
\hline História & 1 & 1 & 2 & 2 & 2 \\
\hline Geografia & 1 & 1 & 2 & 2 & 2 \\
\hline Matemática & 6 & 6 & 4 & 4 & 4 \\
\hline Ciências & 2 & 2 & 2 & 2 & 2 \\
\hline Música & 2 & 2 & 2 & 2 & 2 \\
\hline Língua Portuguesa & 4 & 4 & 4 & 4 & 4 \\
\hline História do Brasil & 1 & 1 & 1 & 1 & 1 \\
\hline Geografia do Brasil & 1 & 1 & 1 & 1 & 1 \\
\hline Educação Artística & 2 & 2 & 2 & 2 & 2 \\
\hline Educação Física & 2 & 2 & 2 & 2 & 2 \\
\hline Inglês & & & 2 & 2 & 2 \\
\hline Religião* & 1 & 1 & 1 & 1 & 1 \\
\hline Total de horas semanais & 30 & 30 & 30 & 30 & 30 \\
\hline
\end{tabular}

*optativa

Figura 1 - Grade Curricular do Ensino Fundamental I da Scuola Italiana Eugenio Montale 
Podemos notar que no $5^{\circ}$ ano do Fundamental I os alunos têm 5 aulas semanais de Língua Italiana e 4 aulas semanais de Língua Portuguesa. A divisão educacional segue a brasileira, em relação à duração de cada ciclo, mas a nomenclatura educacional utilizada é italiana: Scuola dell'Infanzia, Scuola Primaria, Scuola Secondaria di I Grado e Scuola Secondaria di II Grado. Como existem algumas diferenças de nomenclatura e de faixa etária dos alunos entre a divisão italiana e a divisão brasileira, apresentamos um breve quadro comparativo:

\section{Scuola Italiana}

\begin{tabular}{|l|l|l|}
\hline Nomenclatura & Duração & Idade dos alunos (no início do ciclo) \\
\hline Scuola dell'infanzia & 3 anos & Entre 3 e 5 anos \\
\hline Scuola primaria & 5 anos & Entre 6 e 7 anos \\
\hline $\begin{array}{l}\text { Scuola Secondaria di I Grado } \\
\text { (Scuola Media) }\end{array}$ & 3 anos & Entre 11 e 12 anos \\
\hline $\begin{array}{l}\text { Scuola Secondaria di II Grado } \\
\text { (Scuola Superiore ou Liceo) }\end{array}$ & 5 anos & Entre 14 e 15 anos \\
\hline
\end{tabular}

Quadro 3 - Divisão Educacional Italiana

\section{Escola Brasileira}

\begin{tabular}{|l|l|l|}
\hline Nomenclatura & Duração & $\begin{array}{l}\text { Idade dos alunos (no início } \\
\text { do ciclo) }\end{array}$ \\
\hline Pré escola/ Jardim de infância & 3 anos & Entre 3 e 5 anos \\
\hline Ensino Fundamental I & 5 anos & Entre 6 e 7 anos \\
\hline Ensino Fundamental II & 4 anos & Entre 11 e 12 anos \\
\hline Ensino Médio & 3 anos & Entre 15 e 16 anos \\
\hline
\end{tabular}

\section{Quadro 4 - Divisão Educacional Brasileira}

Na conclusão do Ensino Fundamental II (ou da Scuola Secondaria di I Grado), os alunos da Montale são submetidos ao exame di Stato Conclusivo del Primo Ciclo di Istruzione, um exame obrigatório instituído pelo Ministero della Pubblica Istruzione, realizado em todas as escolas italianas no mundo. $\mathrm{O}$ exame é realizado por uma banca de professores da escola, presidida por um comissário enviado pelo Governo Italiano. Trata-se de uma avaliação global dos conhecimentos e das competências dos alunos, tanto do ponto de vista da escrita, quanto da oralidade. Os alunos aprovados recebem o primeiro Diploma di Stato Italiano (reconhecido pela União Europeia). 
Os alunos que frequentam a escola são principalmente brasileiros e italianos, mas há também alunos estrangeiros de outras nacionalidades. O corpo docente é composto por professores italianos e brasileiros.

Sendo assim, nota-se que há um conjunto de fatores distintos que convergem no mesmo espaço e que, ao mesmo tempo, formam a complexidade do contexto dessa escola, particularmente interessante do ponto de vista pragmático, pois envolve o ensino de língua materna (L1), de segunda língua (L2) e de língua estrangeira (LE), proporcionando uma integração e uma interação cultural entre os alunos bilíngues de português e italiano.

Não nos deteremos aqui a tratar das questões de didática relacionadas ao ensinoaprendizagem de L1, L2 e LE, porque isso exigiria uma outra pesquisa, nosso intuito é somente o de descrever o contexto de ensino dessas duas línguas. Dessa forma, entendemos como língua materna (L1) a língua que se aprende nos primeiros anos de vida, em geral, com os pais, e que se fala em casa, com os amigos, parentes, em situações públicas, na escola etc. Já a segunda língua (L2) é a língua não materna, ou seja, é a língua que se aprende depois da primeira.

Pallotti (2006) distingue os aprendizes de segunda língua em aprendizes espontâneos ou naturais e aprendizes guiados ou escolares. Embora existam diferenças entre os dois tipos de aprendizados, ambos se baseiam fundamentalmente em processos comuns. As sequências de aprendizagem, o transfer, as estratégias comunicativas, os fatores afetivos ou a atenção para a forma linguística estão presentes tanto nos aprendizes espontâneos como nos aprendizes guiados. Nesta pesquisa, não usaremos esta distinção, mas chamaremos os aprendizes espontâneos de uma segunda língua de (L2) e, para os aprendizes guiados, usaremos (LE).

Desse modo, segunda língua (L2) é a língua que é aprendida no país em que ela é falada e é utilizada nos mesmos contextos da L1 (casa, escola, amigos, parentes etc.). A aquisição acontece de modo espontâneo ou natural, ou seja, não ocorre o ensino explícito de regras, a língua é apreendida por meio das interações sociais. Em outras palavras, o input (material linguístico ao qual o aprendiz é exposto) é maior, não é controlado e existem mais possibilidades de uso.

Já a língua estrangeira ( $L E)$ é a língua que é aprendida fora do país no qual ela é habitualmente falada. A aprendizagem é realizada através de instrução formal, dá-se 
normalmente em contexto escolar. O input é menor, controlado, e com menor exposição e possibilidades de uso "real". 7

Na Scuola Italiana Eugenio Montale, o português brasileiro é uma língua materna para os aprendizes brasileiros, no entanto, essa língua é pouco usada durante as atividades escolares. A língua italiana para os alunos italianos é uma língua materna, mas não é falada no país em que o aluno vive, falta-lhes, portanto, a possibilidade de usar a língua italiana nos contextos sociais públicos, além da escola.

O italiano para os alunos brasileiros é língua estrangeira porque não é aprendida no país em que se fala, mas a esta língua é dedicada a maior parte das atividades escolares. $\mathrm{O}$ português para os alunos italianos é segunda língua porque é aprendida no país em que se fala, mas, na escola, os alunos tem pouca oportunidade de usá-la.

Portanto, as crianças participantes da pesquisa apresentam diferentes níveis de bilinguismo. A partir da classificação de Harmers e Blanc (2000), em relação às competências linguísticas relativas em cada língua (português e italiano), podemos dizer que algumas crianças apresentam bilinguismo balanceado (competência linguística equivalente em ambas as línguas) e algumas apresentam bilinguismo dominante (maior competência linguística em uma das línguas, geralmente na língua que foi adquirida primeiro - L1). Já em relação ao aspecto cognitivo, algumas crianças apresentam bilinguismo simultâneo (quando foi exposta a duas línguas desde o nascimento e as adquiriu ao mesmo tempo), por exemplo, crianças com pais de nacionalidades diferentes que interagem em casa em suas línguas maternas. E outras crianças apresentam bilinguismo consecutivo (decorrente da exposição à segunda língua depois da aquisição da língua materna, ou seja, a criança adquiriu a L2 após ter assimilado as bases linguísticas da L1).

Assim, o contexto dessa escola bilíngue e os participantes da pesquisa são caracterizados pelo hibridismo. Essa característica se encontra tanto no modo como se organiza a escola como na heterogeneidade dos estudantes que a frequentam.

Dessa forma, estudar, sob uma perspectiva pragmática, a construção das relações pessoais entre esses falantes, em sala de aula, é lidar com uma perspectiva cross-cultural e intercultural simultaneamente, ou seja, é promover a comparação entre duas culturas, focalizando a interação entre os falantes nativos e não nativos das duas línguas. Ao mesmo

\footnotetext{
${ }^{7}$ Krashen (1981) faz uma distinção entre aquisição e aprendizagem (acquisition e learning, em inglês). A primeira seria espontânea, inconsciente, já a segunda, seria guiada e caracterizada pela atenção consciente das estruturas linguísticas.
} 
tempo, é se deparar com o ensino interlinguístico da Pragmática, isto é, com o modo como os aprendizes de língua estrangeira (português ou italiano) percebem as nuances pragmáticas de cada língua.

A seguir, apresentaremos, de forma mais detalhada, os participantes da pesquisa.

\subsection{OS PARTICIPANTES DA PESQUISA}

Os participantes da pesquisa foram os alunos do último ano da Scuola Primaria (o equivalente ao $5^{\circ}$ ano do Ensino Fundamental I) e as respectivas professoras de Língua Portuguesa e Língua Italiana. O corpus da pesquisa foi composto a partir da gravação de aulas, das quais participaram13 crianças, 9 delas nascidas no Brasil e 4 nascidas na Itália, com idade entre 9 e 12 anos, todas falantes bilíngues de italiano e português brasileiro.

Os dados que serão apresentados, a seguir, foram obtidos diretamente das crianças participantes da pesquisa por meio do preenchimento de um questionário. $\mathrm{O}$ nome dos participantes foi substituído pelas letras iniciais de cada nome para preservar a identidade dos falantes. Quando o nome de mais de um falante começava com a mesma letra, para diferenciá-los, optou-se por acrescentar em um deles também a útima letra do nome. Os dados apresentados foram divididos em duas tabelas somente para facilitar a apresentação das informações. Mantivemos a ordem das informações solicitadas no questionário.

\begin{tabular}{|l|l|l|l|l|l|l|}
\hline $\begin{array}{l}\text { N } \\
\text { O } \\
\text { M } \\
\mathbf{E}\end{array}$ & IDADE & $\begin{array}{l}\text { LOCAL } \\
\text { DE } \\
\text { NASCIME } \\
\text { NTO }\end{array}$ & $\begin{array}{l}\text { NACIONALI } \\
\text { DADE } \\
\text { DO PAI }\end{array}$ & $\begin{array}{l}\text { NACIONALI } \\
\text { DADE } \\
\text { DA MÃE }\end{array}$ & $\begin{array}{l}\text { NACIONALI } \\
\text { DADE DO } \\
\text { AVÔ E } \\
\text { DA AVÓ } \\
\text { PATERNOS }\end{array}$ & $\begin{array}{l}\text { NACIONALI } \\
\text { DADE DO } \\
\text { AVÔ E } \\
\text { DA AVÓ } \\
\text { MATERNOS }\end{array}$ \\
\hline A & 9 anos & Alessandria & ITA & ITA & FRA/FRA & FRA/FRA \\
\hline B & 10 anos & São Paulo & BRA & BRA & BRA/BRA & IT/BRA \\
\hline C & 10 anos & Salvador & BRA & BRA & ITA/ITA & BRA/BRA \\
\hline F & 10 anos & São Paulo & BRA & BRA & ITA/BRA & BRA/BRA \\
\hline $\begin{array}{l}\text { F } \\
\text { o }\end{array}$ & 10 anos & Roma & ITA & ITA & ITA/ITA & ITA/ITA \\
\hline G & 12 anos & São Paulo & BRA & BRA & BRA/BRA & BRA/BRA \\
\hline $\begin{array}{l}\text { G } \\
\text { i }\end{array}$ & 10 anos & São Paulo & ITA & BRA & ITA/ITA & ALE/BRA \\
\hline L & 10 anos & $\begin{array}{l}\text { Belo } \\
\text { Horizonte }\end{array}$ & BRA & BRA & BRA/BRA & BRA/BRA \\
\hline M & 10 anos & Spoleto & ITA & ESP & ITA/ITA & ESP/ESP \\
\hline
\end{tabular}




\begin{tabular}{|l|l|l|l|l|l|l|}
\hline $\begin{array}{l}\mathrm{R} \\
\mathrm{a}\end{array}$ & 10 anos & São Paulo & BRA & BRA & BRA/BRA & BRA/BRA \\
\hline $\mathrm{R}$ & 10 anos & São Paulo & ESP & ITA & ESP/ESP & ITA/ITA \\
\hline $\mathrm{S}$ & 11 anos & Novara & ITA & ITA & ITA/ITA & ITA/ITA \\
\hline $\mathrm{T}$ & 10 anos & São Paulo & ARG & ITA & ARG/ARG & ITA/ITA \\
\hline
\end{tabular}

Quadro 5 - Dados pessoais dos informantes- parte 1

\begin{tabular}{|c|c|c|c|c|c|}
\hline NOME & $\begin{array}{l}\text { LÍNGUAS } \\
\text { FALADAS } \\
\text { EM CASA }\end{array}$ & $\begin{array}{l}\text { CIDADES } \\
\text { QUE JÁ } \\
\text { MOROU }\end{array}$ & $\begin{array}{l}\text { TEMPO QUE } \\
\text { VIVEU EM } \\
\text { CADA } \\
\text { CIDADE }\end{array}$ & $\begin{array}{l}\text { TEMPO QUE } \\
\text { ESTUDA NA } \\
\text { MONTALE }\end{array}$ & $\begin{array}{l}\text { QUAIS } \\
\text { LÍNGUAS } \\
\text { FALA COM OS } \\
\text { AMIGOS }\end{array}$ \\
\hline A & italiano & $\begin{array}{l}\text { Alessandria e } \\
\text { São Paulo }\end{array}$ & 4 anos/ 5 anos & 5 anos & $\begin{array}{l}\text { português e } \\
\text { italiano }\end{array}$ \\
\hline $\mathrm{B}$ & inglês & $\begin{array}{l}\text { Flórida e São } \\
\text { Paulo }\end{array}$ & 5 anos/ 5 anos & 1 ano & Português \\
\hline $\mathrm{C}$ & português & São Paulo & 10 anos & 2 anos & Português \\
\hline $\mathrm{F}$ & português & São Paulo & 10 anos & 4 anos & $\begin{array}{l}\text { português e } \\
\text { italiano }\end{array}$ \\
\hline Fo & italiano & $\begin{array}{l}\text { Roma/ Belo } \\
\text { Horizonte e } \\
\text { São Paulo }\end{array}$ & $\begin{array}{l}7 \text { anos } / 3 \text { anos } / 5 \\
\text { meses }\end{array}$ & 5 meses & $\begin{array}{l}\text { português e } \\
\text { italiano }\end{array}$ \\
\hline G & português & São Paulo & 12 anos & 4 meses & Português \\
\hline $\mathrm{Gi}$ & $\begin{array}{l}\text { português e } \\
\text { italiano }\end{array}$ & São Paulo & 10 anos & 6 anos & $\begin{array}{l}\text { português e } \\
\text { italiano }\end{array}$ \\
\hline $\mathrm{L}$ & português & $\begin{array}{l}\text { Belo } \\
\text { Horizonte e } \\
\text { São Paulo }\end{array}$ & $\begin{array}{l}2 \text { meses/ } 10 \\
\text { anos }\end{array}$ & 6 anos & Português \\
\hline $\mathrm{M}$ & $\begin{array}{l}\text { italiano e } \\
\text { espanhol }\end{array}$ & $\begin{array}{l}\text { Spoleto e } \\
\text { São Paulo }\end{array}$ & $\begin{array}{l}10 \text { anos/ } 6 \\
\text { meses }\end{array}$ & 6 meses & $\begin{array}{l}\text { italiano, espanhol } \\
\text { e português }\end{array}$ \\
\hline $\mathrm{Ra}$ & português & São Paulo & 10 anos & 5 anos & português e inglês \\
\hline $\mathrm{R}$ & $\begin{array}{l}\text { italiano e } \\
\text { português }\end{array}$ & São Paulo & 10 anos & 4 meses & $\begin{array}{l}\text { italiano e } \\
\text { português }\end{array}$ \\
\hline$S$ & italiano & $\begin{array}{l}\text { Novara e São } \\
\text { Paulo }\end{array}$ & $\begin{array}{l}10 \text { anos/ } 9 \\
\text { meses }\end{array}$ & 9 meses & $\begin{array}{l}\text { italiano e } \\
\text { português }\end{array}$ \\
\hline $\mathrm{T}$ & $\begin{array}{l}\text { espanhol e } \\
\text { italiano }\end{array}$ & São Paulo & 10 anos & 8 anos & Português \\
\hline
\end{tabular}

Quadro 6 - Dados pessoais dos informantes- parte 2

Em relação às professoras participantes da pesquisa, a professora de Língua Portuguesa é brasileira e concluiu a graduação em Pedagogia, em 1986, pela Universidade São Marcos. Em 2012, fez um curso de especialização (pós-graduação latu sensu) em Educação Ambiental no Centro Universitário Senac. Trabalha, há mais de 20 anos, como professora polivalente das séries iniciais do Ensino Fundamental I, principalmente com 
Língua Portuguesa. Começou a trabalhar na Scuola Italiana Eugenio Montale, em 2010, como professora especialista de Língua Portuguesa, História e Geografia do Brasil.

A professora de Língua Italiana também é brasileira e concluiu a graduação em Letras, em 2007, com habilitação em Português e Italiano na Universidade de São Paulo. Em 2012, concluiu o Mestrado no Programa de Pós-Graduação em Língua, Literatura e Cultura Italianas na mesma Universidade e atualmente é doutoranda no mesmo Programa PósGraduação e na mesma universidade. Trabalha na Scuola Italiana Eugenio Montale desde 2011.

\subsection{PROCEDIMENTOS E INSTRUMENTOS UTILIZADOS NA COLETA DE DADOS}

O primeiro passo para a coleta de dados foi solicitar a permissão da escola para a realização da pesquisa dentro da instituição e o envio de um termo de esclarecimento e consentimento aos pais/responsáveis dos alunos que participaríam da pesquisa. Após a autorização, utilizamos os seguintes instrumentos para realizar a coleta dos dados: entrevistas com as professoras, videogravação das aulas e questionário para os alunos.

A fim de que pudéssemos realizar a coleta dos dados e tivéssemos elementos que pudessem ser comparados entre si, fizemos uma breve entrevista com a professora de português e com a professora de italiano do $5^{\circ}$ ano do Fundamental I, perguntando a elas quais atividades pretendiam realizar com os alunos nas próximas aulas. Nossa hipótese era a de que aulas com as mesmas atividades ou com atividades parecidas pudessem favorecer a produção dos mesmos atos de fala nas duas línguas.

Dessa forma, escolhemos, para a coleta dos dados, duas aulas em que as professoras trabalhariam com os alunos a leitura e a compreensão de textos. Durante a aula de português, a professora trabalharia com o gênero da narrativa e, na aula de italiano, a professora desenvolveria atividades com um texto informativo e com um poema. Achamos que o trabalho com a compreensão de textos, por apresentar um formato aberto e subjetivo, possibilitaria uma interação mais espontânea em sala de aula e, consequentemente, favoreceria o aparecimento de diversos atos de fala.

Optamos por realizar a coleta dos dados por meio de videogravações. A videogravação foi escolhida como recurso metodológico, porque, além de possibilitar a 
utilização de material autêntico, permite o registro simultâneo de diversas variáveis que coexistem no contexto. Assim, segundo Loizos (2008), o registro em vídeo faz-se necessário "sempre que algum conjunto de ações é complexo e difícil de ser descrito compreensivamente por um único observador, enquanto este se desenrola" (LOIZOS, 2008, p. 149). Portanto, devido à complexidade da abordagem escolhida, optamos por produzir registros confiáveis do trabalho de campo, por meio de videogravação, de forma que pudéssemos apreender, selecionar e avaliar, posteriormente, os vários aspectos presentes na interação dentro daquele determinado contexto.

Para Honorato et al. (2006), a captação de imagens em vídeos é uma rica fonte de elementos, especialmente, em pesquisa com crianças. De acordo com as autoras, a integração do som e das imagens em movimento pode ajudar a desvendar a complexa rede de produção de significados e de sentidos. Garcez et al. (2011) afirmam que o uso adequado da imagem em movimento, aliado ao áudio, permite capturar aspectos difíceis de serem captados com outros recursos, tais como expressões corporais, faciais, gestuais, expressões verbais, mudança de entonação da voz etc. Embora nosso objetivo não seja o de analisar os recursos não-verbais e paraverbais, sabemos da importância que eles têm na construção do significado e não podemos ignorá-los, dessa forma, sempre que se fizer necessário, acenaremos para eles durante a análise dos dados.

Outras vantagens das videogravações são: minimizar a intervenção do pesquisador (HONORATO et al, 2006); poder revisitar o campo inúmeras vezes e em diferentes momentos (LEONARDOS; FERRAZ; GONÇALVEZ,1999); oferecer diversas possibilidades de visualizar o material videogravado, acelerando, saltando partes, pausando, retrocedendo, avançando, repetindo a visualização quantas vezes for necessário para uma boa apreensão e interpretação do material (SADALLA; LAROCCA, 2004).

Sobre os aspectos éticos que envolvem a pesquisa com videogravação e a futura utilização das imagens, antes da coleta de dados, pedimos autorização para a instituição de ensino e, em seguida, como já dissemos, enviamos um termo de consentimento livre e esclarecido aos pais (ou responsáveis) das crianças que participariam da pesquisa (ver ANEXO F).

No termo, além da ciência da pesquisa realizada em sala de aula, os pais dos alunos poderiam escolher dar autorização para a utilização dos seguintes materiais: (1) vídeos, áudio e transcrições, (2) somente áudio e transcrições, (3) somente transcrições das aulas. Todos os pais das crianças envolvidas nos autorizaram a fazer uso dos vídeos, áudios e transcrições em 
contexto didático e de pesquisa. As professoras, participantes da pesquisa, também receberam esse termo e deram seu consentimento para a utilização de suas imagens, áudio e transcrições das aulas.

Ao término das gravações, um questionário com perguntas pessoais, foi entregue somente para os alunos. O questionário solicitava as informações que foram apresentadas anteriormente, nos Quadros 5 e 6 - Dados pessoais dos informantes parte 1 e 2 . O objetivo dessa coleta de dados era o de fazer um levantamento acerca do perfil das crianças participantes da pesquisa. As respostas fornecidas poderiam nos auxiliar, posteriormente, na análise dos dados.

Sobre os aspectos técnicos das videogravações, posicionamos a câmera dentro da sala de aula, ao lado do quadro negro, de modo que todos os alunos fossem focalizados frontalmente, somente as professoras, em alguns momentos, quando se movimentavam para trás da câmera, não foram focalizadas.

Realizamos a gravação de duas aulas, uma de língua portuguesa e outra de língua italiana, de aproximadamente 60 minutos cada. A gravação das aulas foi realizada integralmente, de maneira ininterrupta, e nosso material total corresponde a quase duas horas de videogravações. Sabemos que para uma pesquisa empírica qualitativa é pouco tempo de gravação, mas entendemos que para um estudo de caso e para suscitar a reflexão sobre alguns aspectos que envolvem atos de fala, Pragmática e cortesia verbal em sala de aula, os dados fornecidos sejam úteis.

\subsection{OS PROCEDIMENTOS DE ANÁLISE}

Após a coleta de dados, assistimos às videogravações e realizamos uma espécie de minutagem da aula de português e de italiano, a fim de entender suas dinâmicas e, ao mesmo tempo, visualizar quais atos de fala estavam presentes naquelas interações. Na minutagem, descrevemos de forma sucinta o que alunos e professoras realizaram em cada minuto de aula (ANEXOS A e B). A partir disso, observamos que cada aula se compunha, basicamente, por três tipos de atividades: leitura, exposição e interação. Com relação à identificação de todos os atos de fala presentes naquelas interações e à posterior seleção dos que apareciam em maior número, percebemos que seria necessário um detalhamento maior dos dados. Desse modo, optamos por realizar também, a transcrição integral dessas duas aulas (ANEXOS C e D). 
As transcrições foram realizadas como tentativa de "traduzir" um texto oral espontâneo para a forma escrita, portanto não tivemos a preocupação com as normas de transcrição. Procuramos escrever da forma que ouvíamos, pois não queríamos descaracterizar o texto falado, para não eliminar aspectos que iriam nos ajudar a entender os fenômenos que queríamos analisar. Buscamos também descrever (entre parênteses) todos os elementos não verbais e paraverbais que achamos significativos para a compreensão do contexto dos atos de fala durante a interação, como gestos, olhares, expressões faciais, mudança no tom de voz etc.

Feito isso, o critério para a seleção dos atos de fala foi quantitativo, isto é, a escolha foi feita observando o número de ocorrências e verificando o que aparecia com maior frequência. Nossa hipótese era a de que os pedidos seriam os atos de fala mais frequentes, pois havíamos imaginado que na sala de aula os alunos pudessem pedir autorização para realizar ações, explicações ao professor, algum material emprestado aos colegas etc, mas para nossa surpresa, os atos que mais apareceram na interação, tanto entre professoras e alunos quanto entre alunos, foram os atos da discordância e da desaprovação.

A partir disso, buscamos, através da teoria dos atos de fala de Austin (1990 [1962]) e Searle (2009 [1969]) e da teoria de cortesia de Brown \& Levinson (1987 [1978]), entender e caracterizar os atos de fala de discordância e desaprovação. Para realizar a análise dos dados, selecionamos em nosso corpus os momentos da aula de português e de italiano em que esses atos de fala apareciam e fizemos uma segunda transcrição, somente desses fragmentos, seguindo as normas de transcrição para entrevistas gravadas, assim como propostas pelo projeto NURC.

O Projeto NURC (Norma Urbana Culta) teve seu início em 1969, com o propósito de documentar e estudar a norma culta falada em cinco capitais brasileiras. Como o modo de realização da pesquisa assemelha-se ao nosso, em relação aos tipos de dados orais e em relação aos procedimentos de coleta (gravação em áudio e, no nosso caso, também, vídeo) pensamos que as normas utilizadas para transcrever as entrevistas do projeto seriam adequadas para as transcrições dos nossos dados. Sendo assim, as normas utilizadas foram as seguintes:

\begin{tabular}{|l|l|l|}
\hline OCORRÊNCIAS & SINAIS & EXEMPLIFICAÇÃO* \\
\hline $\begin{array}{l}\text { Incompreensão de palavras ou } \\
\text { segmentos }\end{array}$ & $($ ) & $\begin{array}{l}\text { do nível de renda... ( ) } \\
\text { nível de renda nominal... }\end{array}$ \\
\hline Hipótese do que se ouviu & (hipótese) & (estou) meio preocupado \\
\hline
\end{tabular}




\begin{tabular}{|c|c|c|}
\hline $\begin{array}{l}\text { Truncamento (havendo } \\
\text { homografia, usa-se acento } \\
\text { indicativo da tônica e/ou timbre) }\end{array}$ & / & e comé/ e reinicia \\
\hline Entonação enfática & Maiúscula & $\begin{array}{l}\text { porque as pessoas reTÊM } \\
\text { moeda }\end{array}$ \\
\hline $\begin{array}{l}\text { Prolongamento de vogal e } \\
\text { consoante (como s, r) }\end{array}$ & $\begin{array}{l}\text { :: podendo aumentar } \\
\text { para:::: } \\
\text { ou mais }\end{array}$ & $\begin{array}{l}\text { ao emprestarem os... } \\
\text { éh }:: . \text {... o dinheiro }\end{array}$ \\
\hline Silabação & - & por motivo tran-sa-ção \\
\hline Interrogação & $?$ & e o Banco... Central... certo? \\
\hline Qualquer pausa & $\cdots$ & $\begin{array}{l}\text { são três motivos ... ou três razões... } \\
\text { que fazem com que se retenha } \\
\text { moeda... existe uma... retenção }\end{array}$ \\
\hline $\begin{array}{l}\text { Comentários descritivos do } \\
\text { transcritor }\end{array}$ & (( minúscula)) & $(($ tossiu $))$ \\
\hline $\begin{array}{l}\text { Comentários que quebram a } \\
\text { seqüência temática da exposição; } \\
\text { desvio temático }\end{array}$ & ---- & $\begin{array}{l}\text {...a demanda de moeda __ vamos } \\
\text { dar essa notação _ _ demanda de } \\
\text { moeda por motivo }\end{array}$ \\
\hline $\begin{array}{l}\text { Superposição, simultaneidade de } \\
\text { vozes }\end{array}$ & [ ligando as linhas & $\begin{array}{l}\text { A. na[ casa da sua irmã } \\
\text { B. sexta-feira? } \\
\text { A. fizeram[ lá... } \\
\text { B. cozinharam lá? }\end{array}$ \\
\hline $\begin{array}{l}\text { Indicação de que a fala foi tomada } \\
\text { ou interrompida em determinado } \\
\text { ponto. Não no seu início, por } \\
\text { exemplo. }\end{array}$ & $(\ldots)$ & (...) nós vimos que existem... \\
\hline $\begin{array}{l}\text { Citações literais ou leituras de } \\
\text { textos, durante a gravação }\end{array}$ & " " & $\begin{array}{l}\text { Pedro Lima... ah escreve na } \\
\text { ocasião ..." O cinema falado em } \\
\text { língua estrangeira não precisa de } \\
\text { nenhuma ba RREIra entre nós"... }\end{array}$ \\
\hline
\end{tabular}

Quadro 7 - Normas de transcrição utilizadas pelo Projeto NURC

\section{Observações:}

1. Iniciais maiúsculas: só para nomes próprios ou o para siglas (USP etc.).

2. Fáticos: ah, éh,ahn, ehn, uhn, tá (não por está: tá? você está brava?).

3.Nomes de obras ou nomes comuns estrangeiros são grifados.

4. Números: por extenso.

5. Não se indica o ponto de exclamação (frase exclamativa).

6. Não se anota o cadenciamento da frase.

7. Podem-se combinar sinais. Por exemplo: oh::.... (alongamento e pausa). 
8. Não se utilizam sinais de pausa, típicos da língua escrita, como ponto-e-vígula, ponto final, dois-pontos, vírgula. As reticências marcam qualquer tipo de pausa.

(Fonte: PRETI, D. (org.),Cortesia Verbal, São Paulo: Humanitas, 2008).

Em seguida, como os atos de fala de discordância e de desaprovação colocam em risco a imagem do falante e do interlocutor durante a interação, incitou-se o interesse em descobrir de que forma os falantes mantinham o equilíbrio das relações pessoais em sala de aula através da cortesia verbal. Quais mecanismos ou estratégias eles utilizavam? Assim, chegamos à conclusão de que seria produtivo estudar a atenuação e decidimos observar se e em que medida era possível identificar a utilização de estratégias atenuadoras na produção desses atos de fala. Para isso, recorremos à classificação dos procedimentos atenuadores proposta por Briz e Albelda (2013), que serão elencados e explicados na próxima seção.

\subsubsection{Procedimentos atenuadores}

Briz e Albelda (2013) identificaram vinte e dois procedimentos atenuadores e os apresentaram em forma de proposta teórica e metodológica para a análise empírica qualitativa e quantitativa da atenuação em espanhol e português, sob a perspectiva pragmática e sociolinguística. A ficha foi elaborada pelo grupo Val.Es.Co da Universidade de Valência, a partir de uma ficha sociolinguística proposta anteriormente por Albelda e Cestero (2011) e Cestero e Albelda (2012) no marco do projeto PRESEEA. Por se tratar de uma categorização que, de uma forma geral, abrange as características das línguas latinas, a escolhemos por achá-la adequada para fundamentar a análise do nosso corpus de atos do português brasileiro e do italiano.

Abaixo, descrevemos as táticas ou procedimentos atenuadores identificados pelos autores. Adaptamos a classificação e fornecemos exemplos em português brasileiro e italiano, bem como, apresentamos, também, alguns exemplos do nosso corpus.

\section{Modificadores morfológicos internos: diminutivos}

O primeiro recurso que os autores sublinham como forma de atenuação dos atos de fala são os modificadores morfológicos internos, como os diminutivos. 
Exemplos: sufixos

PORTUGUÊS: inho, inha, inhos, inhas

ITALIANO: etto, etta, etti, ette, ino, ina, ini, ine

No nosso corpus de pesquisa, essa estratégia apareceu somente uma vez, em um ato de desaprovação realizado pela professora de português e nenhuma vez em italiano. Abaixo, apresentamos o fragmento:

\section{FRAGMENTO DES-PT n ${ }^{\circ} 5$}

$R a$ : eu VIVO sem celular de boa

$L$ : eu não vivo sem TABLET

((alguns alunos estão falando ao mesmo tempo-barulho))

$R$ : TÁ mas se não tinha celular lá como é que fizeram aquela máquina de tecido?

Prof PORT: peraí [gente

$$
\text { Fo: eu não VIVO sem PSP [sem telefone }
$$

$F$ : é:: eu também não vivo sem PSP

Prof PORT: gente pera só um pouquinho o R fez uma pergunta FAla

$R$ : ãh se não tinha celular... ãh:: como é que então tinha aquela fábrica de tecido

\section{Modificadores externos}

O segundo recurso apontado pelos autores como elemento que atenua a força ilocucionária do ato de fala são os modificadores externos, como quantificadores minimizadores, quantificadores aproximativos, difusores significativos e palavras ou expressões citadas.

- Quantificadores minimizadores

Exemplos

PORTUGUÊS: um pouco, só, não muito, às vezes

ITALIANO: un po', solo, non molto, alle volte; a volte

- Quantificadores aproximativos:

Exemplos

PORTUGUÊS: bastante, aproximadamente, de alguma maneira

ITALIANO: molto, circa, in qualche modo

- Difusores significativos:

Exemplos

PORTUGUÊS: assim, digamos

ITALIANO: così, diciamo

- Palavras ou expressões citadas 
Essa tática também apareceu no nosso corpus de diferentes maneiras. A seguir, um exemplo em um ato de desaprovação realizado em italiano:

\section{FRAGMENTO DES-IT $n^{\circ} 8$}

\section{Italiano}

L: MAESTRA io stato il primo a:: consegnare Prof IT: OK...F

$F$ : sim eu coloquei lá ((e fa un gesto con la mano))

Prof IT: Ok

((Ra alza la mano $))$

Prof IT: Ra

((B, L e C stanno chiacchierando ad alta voce $))$

Prof IT: ASPETTA B DEVO SENTIRE RA.... B aspetta un attimo

$R a$ : che ora che deve arrivare?
Tradução

L: PROFESSORA eu fui o primeiro a:: entregar Prof IT: OK...F

$F$ : sim eu coloquei lá ((e faz um gesto com a mão))

Prof IT: Ok

((Ra levanta a mão $))$

Prof IT: Ra

((B, L e C estão conversando em voz alta $))$

Prof IT: ESPERA B TENHO QUE OUVIR RA.... B espera um pouco

$R a$ : que horas que tem que chegar?

\section{Termos ou expressões mais suaves para expressar um conteúdo desagradável}

O terceiro procedimento atenuador apontado por Briz \& Albelda (2013) é o uso de termos ou expressões mais suaves para expor um conteúdo desagradável como as lítotes e os eufemismos. Não encontramos a utilização desse recurso nos atos de fala analisados em nosso corpus.

- Lítotes e eufemismo.

Exemplos- Lítotes

PORTUGUÊS: Eu não fiquei feliz com a notícia. (atenua a ideia de que eu fiquei triste)

ITALIANO: Questa notizia non mi rende felice.

Exemplos- Eufemismo

PORTUGUÊS: Você faltou com a verdade. ( no lugar de "você mentiu")

ITALIANO: Non hai detto la verità.

\section{Emprego de palavras estrangeiras}

O quarto recurso apontado pelos autores é o emprego de palavras estrangeiras para atenuar um determinado ato de fala. Também não identificamos a utilização desse procedimento nos atos de fala de discordância e desaprovação do nosso corpus. 


\section{Usos modalizados dos tempo verbais}

A quinta tática atenuadora assinalada pelos autores é a utilização modalizada dos tempos verbais para expressar uma ação de forma mais suave.

- Emprego do condicional no lugar do presente ou do imperativo.

Exemplos

PORTUGUÊS: Você poderia abrir a porta? (Abra a porta! / Você pode abrir a porta?)

ITALIANO: Potresti aprire la porta?(Apri la porta!/ Puoi aprire la porta?)

- Emprego do imperfeito por presente ou imperativo.

Exemplos

PORTUGUÊS: Queria que você falasse com ela. (Quero que você fale com ela/ Fala com ela!)

ITALIANO: Volevo che tu parlassi con lei. (Voglio che parli con lei./ Parla con lei!)

- Emprego do futuro no lugar do presente (futuro de probabilidade em contextos do presente)

Exemplos

PORTUGUÊS: Será que ela vai se atrasar? (Ela vai se atrasar?)

ITALIANO: Lei arriverà in ritardo?

No nosso corpus, observamos a utilização dessa tática somente nos atos de discordância realizados em português, como pode ser observado no exemplo abaixo:

\section{FRAGMENTO DIS-PT $n^{0} 1$}

$[\ldots]$

Prof PORT: então mas AOnde? ele foi ao DEPARTAMENTO da cidade... que que seria esse departamento da cidade? QUAL departamento seria esse?

Fo: na polícia

$T$ : na delegacia

Prof PORT: na delegaCla? será que na delegacia tem uma relação de CARROS e o nome do dono do carro a cor e TUDO mais?

Le Ra: sim

VI. Verbos, construções verbais e partículas discursivas com valor modal que expressam opinião em forma de dúvida ou de probabilidade

O sexto procedimento é o uso de verbos, construções verbais ou partículas discursivas com valor modal que expressam a opinião do falante em forma de dúvida. Essa tática tem como efeito criar uma distância entre a enunciação e o enunciador.

Exemplos

PORTUGUÊS: achar, parecer, ser possível, imaginar, pode ser, talvez, provavelmente 
ITALIANO: pensare, sembrare, essere possibile, immaginare, può essere, forse, secondo me, probabilmente

Essa tática foi observada, apenas, nos atos de discordância presentes em nosso corpus. A seguir, apresentamos um exemplo do corpus de italiano.

\section{FRAGMENTO DIS-IT n ${ }^{0} 5$}

\section{Italiano}

T: maestra noi rimaniamo DUE ORE nell':: autobus e:: ... però cosa facciamo? non ci sarà niENte là?

Prof IT: COME NON CI SARÀ NIENTE?

$T$ : nell'autobus sto dicendo

Prof IT: NIENTE ... potete dorMIre potete parLAre potete canTAre FORSE ... ci sarà un film... per vedere non so

\section{Tradução}

$T$ : professora nós ficaremos DUAS HORAS no:: ônibus e:.... mas o que vamos fazer? não vai ter NAda lá?

Prof IT: COMO NÃO VAI TER NADA?

$T$ : no ônibus estou falando

Prof IT: NADA...vocês podem dorMIr vocês podem conVERsar vocês podem canTAr TALVEZ tenha um filme... para assistir não sei

VII. Verbos, construções verbais e partículas discursivas que expressam fingimento de incerteza, de incompetência ou de ignorância

A sétima tática atenuadora enumerada pelos autores é a utilização de verbos, construções verbais ou partículas discursivas que expressam fingimento de incerteza, de incompetência ou de ignorância.

Exemplos

PORTUGUÊS: não sei, não estou seguro/a, não sou a pessoa mais apropriada para dizer ITALIANO: non lo so, non sono sicuro/a, non sono la persona ideale per dirlo

Não encontramos a utilização desse recurso no nosso corpus de atos de discordância e de desaprovação.

\section{Construções que limitam/restringem a opinião da própria pessoa ou de um determinado âmbito}

O oitavo procedimento refere-se à utilização de construções que limitam ou restringem a opinião da própria pessoa ou de um determinado âmbito, como recurso atenuador que diminui o compromisso do enunciador com o enunciado.

Exemplos

PORTUGUÊS: na minha opinião, no meu modo de ver, acredito eu, mi parece que ITALIANO: secondo me, dal mio punto di vista, credo, mi pare che 
No nosso corpus, encontramos o seguinte exemplo:

\section{FRAGMENTO DIS-PT n $^{0} 12$}

\section{$[\ldots]$}

Prof PORT: quando você ACHA que surgiu o celular? há quanto tempo?

$T: 10$ anos

$L: 100$ anos

Prof PORT: O CELULAR?

$B$ : NÃO...uns 40 anos eu acho

Prof PORT: nossa ((a professora olha para a pesquisadora e dá risada))

((as crianças começam a falar todas ao mesmo tempo tentando acertar a data de criação do celular.

Ra levanta a mão))

Prof PORT: fala

$R a: 20$ anos?

Prof PORT: isso gente o celular é uma invenção MUITO recente

\section{Pedidos, perguntas e ordens expressas de forma indireta. Com formulação afirmativa} ou negativa com ou sem a fórmula "por favor"

O nono recurso que também atenua a força ilocucionária de um ato de fala é formulálo de maneira indireta. A formulação indireta pode ser realizada de modo afirmativo ou negativo com ou sem a utilização da expressão "por favor".

\section{Exemplos}

PORTUGUÊS: Gostaria de um pouco de silêncio, por favor. Preciso escrever e não tenho uma caneta.

ITALIANO: Mi piacerebbe un po' di silenzio, per favore. Ho bisogno di scrivere e non ce l'ho una penna.

Essa tática foi uma das mais utilizadas pelos falantes do nosso corpus, principalmente nos atos de desaprovação tanto em língua italiana, quanto em língua portuguesa. No fragmento abaixo, extraído da aula de italiano, a professora desaprova, indiretamente, o fato de a aluna estar distraída durante a aula, fazendo-lhe a seguinte pergunta:

\section{FRAGMENTO DES-IT n $^{\circ} 3$}

\section{Italiano}

((Durante la lettura, la professoressa disapprova il comportamento di A che stava guardando $G$ al posto di seguire la lettura sul suo libro))

\section{Tradução}

((Durante a leitura, a professora reprova o comportamento de A que olhava para $G$ ao invés de acompanhar a leitura no seu livro)) 
Prof IT: A SEI QUA o in un altro posto?

( $l$ ' alunna si volge)

$S$ : nel mondo delle favole
Prof IT: A VOCÊ ESTÁ AQUI ou em outro lugar?

(a aluna vira-se para frente)

$S$ : no mundo das fábulas

\section{$X$. Expressões de desculpa perante uma interrupção, uma pergunta, um favor ou perante uma expressão de uma opinião}

A décima tática apontada pelos autores como recurso atenuador é o uso de expressões para pedir desculpas perante uma interrupção, uma pergunta, um favor ou perante uma expressão de opinião. Essa tática não foi utilizada pelos falantes do nosso corpus nos atos de discordância e de desaprovação por eles produzidos.

Exemplos

PORTUGUÊS: desculpa eu te interromper; desculpa, mas não concordo com você ITALIANO: scusa se ti interrompo, scusa ma non sono d'accordo con te

XI. Estruturas sintáticas condicionais, concessivas ou temporais que modificam ou restringem o ato de fala

A décima primeira tática refere-se à utilização de estruturas sintáticas condicionais, concessivas ou temporais que modificam ou restringem o ato de fala.

Exemplos

PORTUGUÊS: se, mas

ITALIANO: se, però, ma

No nosso corpus, encontramos o seguinte exemplo. A professora de italiano discorda do aluno e atenua sua discordância usando uma estrutura sintática condicional que contrapõe uma ideia modificando-a.

\section{FRAGMENTO DIS-IT $\mathbf{n}^{0} 7$}

Italiano

$[\ldots]$

Prof IT: fede e religione sono cose diVERse tu puoi avere una religione però... non credere $S$ : credere in qualcosa

Prof IT: sì credere IN qualcosa avere fede è credere in qualcosa può essere una persona può essere un Dio può essere... ((ha lasciato la frase sospesa))

\section{Tradução}

[...]

Prof IT: fé e religião são coisas diFEREntes você pode ter uma religião mas... não acreditar $S$ : acreditar em alguma coisa

Prof IT: sim acreditar EM alguma coisa ter fé é acreditar em algo pode ser uma pessoa pode ser um DEUS pode ser...((deixou a frase suspensa)) 


\section{Partículas e construções justificadoras do dizer ou justificações de desculpas}

O décimo segundo recurso refere-se ao emprego de partículas e construções justificadoras do dizer ou a utilização de justificação de pedido de desculpas.

Exemplos

PORTUGUÊS: é que, porque, como, o que acontece é que, por assim dizer, por falar nisso ITALIANO: è che, perché, siccome, quello che succede è che, nel senso che

Esse recurso apareceu uma única vez no nosso corpus na aula de português. No seguinte exemplo, o aluno usa a construção "mas é que eu pensei" para justificar sua discordância em relação ao que a professora havia afirmado anteriormente.

\section{FRAGMENTO DIS-PT $n^{\circ} 6$}

Prof PORT: AS FÁbricas de tecido ... são uma invenção ... do século dezoito do século dezenove... primeiro surgiram as fábricas... e o celuLAR só pode surgir agora recentemente há pouco mais de 15 anos por conta da:: revolução da tecnologia... então as pessoas se vestiam antes os carros exisTIam:: não é? a energia elétrica surgiu no início do século... vinte

$R$ : mas é que eu pensei... ahn... se existiam as FÁbricas existia já um telefone

Prof PORT: MAS O TELEFONE EXISTE... o:: Bolacha não ligou para o gerente?

$R$ : ENTÃO? ((fez um gesto de confirmação com os braços abertos))

Prof PORT: não o celular ... existia o telefone

\section{Elipses de conclusão, estruturas suspensas}

O décimo terceiro procedimento que pode causar um efeito atenuador nos atos de fala é a utilização de elipses de conclusão ou a utilização de estruturas que ficam suspensas durante o dizer. As elipses são figuras de linguagem que consistem em omitir um termo da frase que não foi enunciado anteriormente, mas é de fácil identificação pelo contexto.

\section{Exemplos}

PORTUGUÊS: No fim da festa, sobre as mesas, copos e garrafas vazias. (elipse do verbo haver)

ITALIANO: Alla fine della festa, sui tavoli, bicchieri e bottiglie vuoti. (elipse del verbo esserci)

No nosso corpus, observamos a utilização de uma estrutura que ficou suspensa durante a desaprovação realizada pela professora de italiano e que se torna compreensível por 
meio do contexto de enunciação. Alunos e professores falavam sobre uma excursão que os alunos faríam com a escola.

\section{FRAGMENTO DES-IT $n^{\circ} 6$}

Italiano

$S$ : maestra quando ci sei andata quanto ci si può rimanere nell'aereo?

$C$ : che aereo?

Prof IT: è una sorpresa .... RIPETO LA STESSA COSA SE VOLETE SAPERE TUTTO PRIMA DI PARTIRE poi quando arrivati lì...
Tradução

$S$ : professora quando você foi quanto tempo pode ficar no avião?

$C$ : que avião?

Prof IT: é uma surpresa... REPITO A MESMA COISA SE VOCÊS QUISEREM SABER TUDO ANTES DE IR depois quando chegarem lá....

\section{Impessoalização I}

A décima quarta e a décima quinta táticas referem-se às impessoalizações, isto é, a procedimentos nos quais o falante se distancia do seu enunciado "jogando" a responsabilidade do dizer para um interlocutor geral. $\mathrm{O}$ falante generaliza para impessoalizar, citando de forma direta as palavras ou o pensamento de outra pessoa para justificar ou introduzir a opinião de maneira menos comprometida. São exemplos:

- Apelar ao juízo da maioria, ou a um interlocutor geral, mediante pronomes.

Exemplos

PORTUGUÊS: nós (inclusivo) ou a gente, você (impessoal)

ITALIANO: noi, tu, si uno

- Apelar ao juízo da maioria mediante formas verbais impessoais

Exemplos

PORTUGUÊS: pelo que dizem, pelo visto, segundo comentam

ITALIANO: secondo quello che dicono, a quanto pare

- Apelar para a instituição ou entidade que se representa

Exemplos

PORTUGUÊS: A escola é responsável pelo ensino da cidadania (mas o professor que usa a frase também o é)

ITALIANO: La scuola è responsabile per l'insegnamento della cittadinanza. (ma lo è anche il professore che usa la frase)

- Generalizar para impessoalizar

Exemplos

PORTUGUÊS: Quando alguém que está dirigindo um carro passa um semáforo vermelho e justifica dizendo: todo mundo faz isso! (A expressão todo mundo foi usada para generalizar um ato individual) 
ITALIANO: Quando qualcuno che guida una macchina passa con il semaforo rosso e si giustifica dicendo: Lo fanno tutti!

\section{$X V$. Impessoalização (II)}

- Citar, de forma direta, as palavras ou o pensamento de outra pessoa para justificar ou introduzir a opinião de maneira menos comprometida.

Exemplos

PORTUGUÊS: Não sou eu quem está dizendo, está escrito na Bíblia, em Lucas 11:28 "Felizes são aqueles que ouvem a palavra de Deus e a obedecem".

ITALIANO: Non sono io che lo sto dicendo, è scritto nella Bibbia, in Luca 11:28 "Beati coloro che ascoltano la parola di Dio e obbediscono".

Um dos exemplos encontrados no nosso corpus refere-se ao momento em que a professora de italiano usou uma frase do aluno $S$ (citação direta) para demonstrar discordância em relação à opinião do aluno. Assim, ao citar de forma direta as palavras de outra pessoa (do aluno S), para justificar ou introduzir sua opinião de maneira menos comprometida, a professora atenuou a força ilocucionária do ato de fala de discordar.

\section{FRAGMENTO DIS-IT $\mathbf{n}^{\circ} 2$}

\section{Italiano}

Prof IT: ASCOLTATI ERA PROPRIO ... QUELLO CHE DICEVA S VERO S ?

((S fa un segno affermativo con la testa))

Prof IT: ma non si sente ascolTAto...quando ti SENTIresti ascoltato dagli altri $\mathrm{S}$ ?

$S:$ così

Prof IT: così come? MA IO TI SENTO se vieni qua da me e mi dici MAESTRA posso andare in bagno? ti dico di sì allora

Fo: no ascoltato nel senso... non nel senso di ascoltare ti ascoltano pure ma non:....

$T$ : TI CREDONO

Fo: uno non ti crede o non:: ...

Prof IT: non dà il valore giusto

Fo: è non dà il valore a quello che dici

Prof IT: AH::::

\section{Tradução}

Prof IT: OUVIDOS ERA EXATAMENTE... AQUILO QUE S DIZIA NÉ S?

((S faz um gesto afirmativo com a cabeça))

Prof IT: mas não se sente ouVIdo... quando você se SENTIria ouvido pelos outros $\mathrm{S}$ ?

$S:$ assim

Prof IT: assim como? MAS EU TE OUÇO se você vem até mim e me diz PROFESSORA eu posso ir ao banheiro? eu te digo de sim então

$F o$ : não ouvido no sentido... não no sentido de ouvir te ouvem mas não::...

$T:$ ACREDITAM EM VOCÊ

Fo: não acreditam em você ou não:: ...

Prof IT: não dão o justo valor

Fo: é não dão valor àquilo que você diz

Prof IT: AH:::

\section{Movimento de reformulação}

A décima sexta tática, enumerada por Briz \& Albelda (2013) como recurso atenuador, é constituída por movimentos de reformulação realizados a partir dos atos do falante, que 
corrige sua própria enunciação, suavizando-a. Incluem-se, também, nesse procedimento, os movimentos de troca de tópico quando eles atenuam parcialmente os conflitos.

Exemplos

PORTUGUÊS: bom, ou seja, isto é, cara, meu

ITALIANO: beh, ossia, cioè

Não encontramos a utilização desse recurso nos atos estudados em nosso corpus.

\section{Concessividade}

O décimo sétimo procedimento é a concessividade, isto é, a formulação, durante a enunciação, de movimentos concessivos-opositivos que minimizam a desconformidade dialógica. São expressões usadas para introduzir um possível acordo e, imediatamente, revelar um desacordo parcial ou total.

Exemplos

PORTUGUÊS: sim... mas, não mas, tudo bem... mas

ITALIANO: sì... ma, no ma, va bene... ma

No corpus, esse recurso foi muito utilizado nas discordâncias em português brasileiro, como podemos observar no exemplo abaixo. O mesmo recurso também apareceu nas discordâncias realizadas em língua italiana, mas em menor frequência.

\section{FRAGMENTO DIS-PT $\mathbf{n}^{0} 1$}

Prof PORT: então gente o::: a gente tá vendo tudo isso que tá acontecendo aqui ... tá acontecendo lá na FÁbrica o gordo sendo tortuRAdo pressioNAdo então aqui o que que ele vai fazer ele vai nos explicar como é:: que as pessoas que conviviam com o gordo e tavam envolvidas na investigação estavam Agindo... essa é a notícia de que o gordo SUMIU então como é que o Mister tá usando seus métodos para descobrir aonde ele foi quem levou, né? ele tem uma pista muito simples que é o carro e um nome, que era um nome falso, onde será que ele foi que ele conseguiu a lista de donos de fusca bordô? onde cês acham que é esse lugar? ONDE PODERIA ser na verdade?

$C$ : naquele lugar

Fo: maquininha de fotocópia...

Prof PORT: então mas AOnde? ele foi ao DEPARTAMENTO da cidade... que que seria esse departamento da cidade? QUAL departamento seria esse?

\section{Marcadores discursivos modais de objetivação}

O décimo oitavo recurso é o da utilização de marcadores discursivos modais de objetivação para suavizar um determinado ato de fala.

Exemplos

PORTUGUÊS: na verdade, sinceramente, obviamente, evidentemente

ITALIANO: in realtà, sinceramente, ovviamente, evidentemente 
A utilização desse recurso foi encontrada somente nos atos de discordância em português brasileiro. Como exemplo apresentamos o seguinte fragmento, no qual a aluna Ra discorda de forma atenuada do seu colega L.

\section{FRAGMENTO DIS-PT $\mathbf{n}^{0} 13$}

Fo: aí eles pegaram o alicate

$L:$ aí eles pegaram o alicate de ponta fina

$R a$ : na realidade o alicate foi primeiro

Prof PORT: ISSO:: o alicate foi primeiro

XIX. Partículas discursivas, expressões de controle e de contato com o interlocutor.

O décimo nono procedimento, citado por Briz e Albelda (2013), refere-se ao emprego de partículas discursivas, expressões de controle e expressões de contato com o interlocutor como tática para atenuar um possível desacordo.

Exemplos

PORTUGUÊS: né? tá? o que você acha?

ITALIANO: no? vero? che ne pensi?

Esse procedimento foi bastante utilizado nos atos presentes em nosso corpus, tanto nos atos de discordância quanto nos atos de desaprovação realizados em ambas as línguas. A seguir, apresentamos um exemplo de discordância da aula de português em que é possível observar sua utilização.

\section{FRAGMENTO DIS-PT $n^{\circ} 8$}

$[\ldots]$

Prof PORT: no GUIA da cidade alguém aqui já viu o guia da cidade de São Paulo?

Fo: $\operatorname{sim}$

Prof PORT: o guia de RUAS?

((Classe fica em silêncio))

Prof PORT:: Não?

Fo: eu sim eu já

Prof PORT: comé/que ele é?

Fo: ele é tipo uma coisa assim ((abre os braços e faz um quadrado no ar))

$B$ : é tipo um quaDRADO tem todas as ruas os nomes

Prof PORT: não... o guia de ruas é um LIvro você pode ter visto um MApa tá?

((B balança a cabeça afirmativamente $))$ 


\section{$X X$. Formas de tratamento e formas apelativas convencionalizadas}

O vigésimo procedimento é a utilização de formas de tratamento ou formas apelativas convencionalizadas para suavizar a força ilocucionária dos atos de fala, incluindo os nomes próprios e apelativos afetuosos.

- Formas de tratamento

Exemplos

PORTUGUÊS: você, senhor, senhora

ITALIANO: $t u$, Lei

- Formas apelativas convencionalizadas

Exemplos

PORTUGUÊS: olha, escuta, meu amor, filha, meu anjo

ITALIANO: guarda, senti, amore, tesoro, figlio

Esse procedimento também foi muito utilizado nos atos presentes em nosso corpus, tanto nos atos de discordância quanto nos atos de desaprovação realizados em ambas as línguas. A utilização desse recurso deu-se, principalmente, através do emprego do nome próprio do falante, mas há também casos em que foram utilizadas outras formas apelativas, como podemos observar no exemplo abaixo, de uma discordância realizada durante da aula de italiano.

\section{FRAGMENTO DIS-IT n ${ }^{\circ} 4$}

Italiano

Prof IT: l'ultimo diRItto... è vai:: F... chi deve leggere? F e A vero?

$L$ : anche io non ho [ancora

$B$ : anche io non ho ancora

Prof IT: MA STIAMO seguendo quall'ordine amore? VAI L e F
Tradução

Prof IT: o último diREIto... é vai:: F... quem deve ler? F e A né?

$L$ : eu também [ainda não

$B$ : eu também ainda não

Prof IT: MAS ESTAMOS seguindo qual ordem amor? VAI L e F

\section{Emprego de elementos prosódicos, paralinguísticos e gestuais}

O último procedimento elencado pelos autores concerne ao emprego de elementos prosódicos, paralinguísticos e gestuais como mecanismo atenuador. São exemplos as mudanças de entonação da voz, risadas, caretas, uso onomatopeicos de palavras etc. 
No nosso corpus, esse mecanismo foi razoavelmente explorado, principalmente em relação à entonação da voz. A seguir, apresentamos um exemplo da aula de português em que a discordância é expressa pela professora através da repetição da resposta do aluno e atenuada pela entonação da voz.

\section{FRAGMENTO DIS-PT n $^{0} 11$}

Prof PORT: não eles vão procurar imiTAdo::res né? de pessoas de voz ou... imitadores de passarinho... são pessoas que tem facilidade de ouvir o som memoriZAR o TIpo a FORma e:: reproduzir tá? e:: ao mesmo tempo ele dividiu a lista telefônica em cinco partes e deu uma pra cada um PRA que será que ele deu... pras pessoas... pros meninos isso?

$L$ : pra Pituca pro Edmundo pra::... Berenice

Prof PORT: pra QUÊ?

Fo: pra anotar

Prof PORT: pra anotar?

$F o:$ as coisas que eles queriam

$L:$ os lugares que ele já foi... e os que não

Prof PORT: poderíam também estar procurando RUas que terminassem com este final de palavra?

$L$ : sim... que terminavam com eta

\section{Outros}

Nessa categoria, os autores incluem possíveis elementos não identificados e nominados anteriormente, isto é, que escaparam à categorização apresentada. Os autores deixam essa categoria em aberto, para novas futuras inclusões.

No próximo capítulo, dedicado à análise, apresentaremos e discutiremos os dados. Durante a análise dos atos de fala procuramos (1) descrever a construção do sentido do ato por meio da descrição das variáveis envolvidas; (2) evidenciar as táticas atenuadoras presentes em cada ato; (3) analisar seus efeitos na interação.

Serão indicados também os casos em que não foram encontrados nenhum recurso atenuador nos atos de discordância e desaprovação. 


\section{ANÁLISE E DISCUSSÃO DOS DADOS}

Neste capítulo, apresentaremos a descrição das aulas e a análise dos atos de discordância e desaprovação enfatizando a utilização dos procedimentos atenuadores e seus efeitos na relação entre alunos e professores na sala de aula, mas também buscando observar sua ausência e as razões que poderiam justificar essa escolha dos falantes.

\subsection{DESCRIÇÃO DAS AULAS ANALISADAS}

\subsubsection{A aula de Português}

A aula de Português que analisamos versou sobre a leitura e a discussão de uma obra que é referência da literatura infanto-juvenil brasileira, $O$ gênio do Crime, de João Carlos Marinho. Nessa aula foram trabalhados, especificamente, os capítulos 30 e 31 do livro.

Por se tratar de uma aula sobre a compreensão e interpretação de um texto narrativo, observamos que ela foi constituída por momentos de leitura, exposição e interação. Como foi mencionado, anteriormente, no item 2.5 dedicado aos procedimentos de análise, a fim de que pudéssemos identificar claramente a dinâmica da aula e quais atos de fala estavam presentes naquelas interações, realizamos previamente uma minutagem.

Nesse trabalho preliminar, tentamos descrever brevemente o que acontecia em cada momento da aula, buscando identificar quanto tempo havia sido dedicado à leitura, à exposição de conceitos e quanto, efetivamente, à interação, uma vez que, nosso interesse concentrava-se, principalmente, nos momentos em que a professora e alunos, mas também alunos entre si estavam empenhados em atividades interacionais mais livres e espontâneas.

Após a minutagem (ANEXO A), observamos como a aula foi dividida e chegamos ao seguinte resultado: 


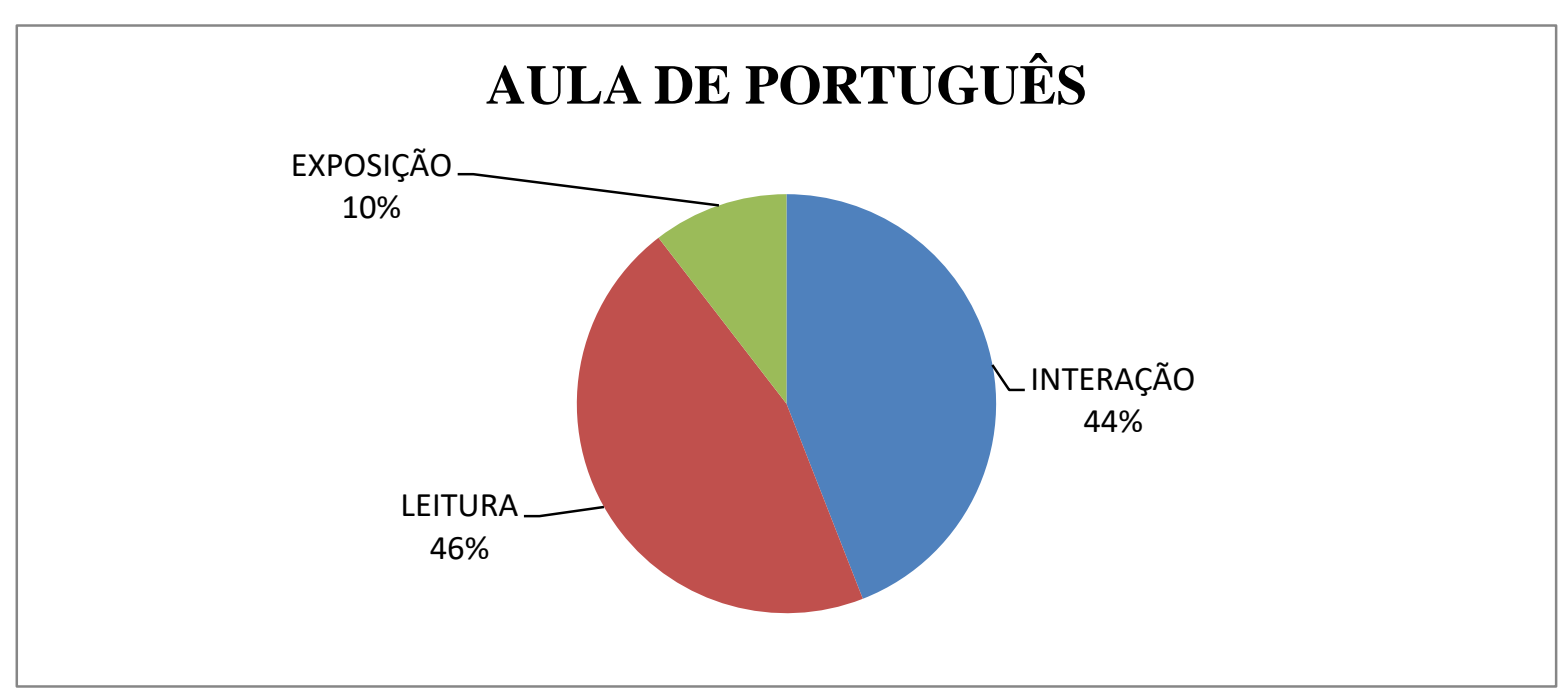

Gráfico 1 - Aula de Português

Como podemos observar, a maior parte do tempo da aula de português foi dedicada à leitura do livro (46\% da aula), enquanto que quase o mesmo tempo, 44\%, foi dedicado à interação, que se concentrou na discussão e em atividades, cuja finalidade era a compreensão da leitura do livro. Somente $10 \%$ do tempo total da aula foi dedicado à exposição de informações pela professora.

De uma forma geral, podemos classificar essa aula como expositivo-interativa, pois notamos o domínio da professora dirigindo, controlando e estimulando as interações verbais. Segundo Silva (2005), na aula expositiva o professor monopoliza o turno e dirige toda a conversação, os alunos têm a função de ouvir, compreender e assimilar as intenções comunicativas. Já na aula expositivo-interativa, o professor dá voz aos alunos, permitindo que eles tenham um papel mais ativo na aula e no processo de ensino-aprendizagem. Assim, a aula expositivo-interativa é "uma aula expositiva em que há o domínio do professor, a motivação deste, a participação dos alunos e a criação de um ambiente adequado de confiança, sem repressões" (SILVA, 2005, p. 21)

Com isso, nessa aula, observamos o domínio da figura da professora, exercendo o papel de "dirigir" uma interação assimétrica, isto é, de ser responsável por controlar a interação em sala de aula. A participação dos alunos é dirigida por ela e ocorreu, na maioria das vezes, por meio de perguntas formuladas por ela sobre o tema discutido em aula. Desse modo, os turnos dos alunos foram delimitados e foram raras as sobreposições de fala. 


\subsubsection{A aula de Italiano}

A aula de Italiano que analisamos girou em torno da leitura e da discussão de dois textos presentes no livro didático utilizado. O primeiro deles foi um poema intitulado La pace verrà [A paz virá] e o segundo foi um texto descritivo-informativo identificado assim: "Alcuni dei diritti contenuti nella Convenzione internazionale sui Diritti dell'infanzia approvata nel 1989 dall'Assemblea Generale delle Nazione Unite (ONU)" (Fonte: Gatto bianco gatto blu. Linguaggi. Per la $5^{\text {a }}$ classe elementare. Laura Valdiserra. Giunti Scuola).

Nos primeiros dez minutos de aula, a professora abordou dois assuntos diversos: a vitória de um time de futebol no dia anterior e o passeio que os alunos faríam com a escola para o sítio Carroção. As crianças puderam fazer perguntas livremente sobre o tema. Em seguida, ocorreu a leitura, a compreensão e interpretação da poesia e, logo após, a leitura, a compreensão e a interpretação do texto descritivo-informativo. Durante as atividades de compreensão e interpretação dos textos, verificou-se um maior direcionamento das perguntas por parte da professora.

Após a realização da minutagem da aula de italiano, observamos que a aula também foi caracterizada por momentos de interação, leitura e exposição de conceitos por parte da professora, mas em proporções diferentes quando comparada com a aula de Português. Na aula de Italiano, embora tenha sido também uma aula pautada na leitura e na discussão de textos, houve mais tempo dedicado à interação em sala de aula do que à leitura. Talvez isso se deva à natureza dos textos trabalhados em sala de aula, porque diversamente da aula de português, em que a professora trabalhou com um texto narrativo e, portanto, mais longo, a professora de italiano trabalhou com dois textos breves, que exigiram menos tempo de leitura por parte dos alunos. Nesse sentido, a maior parte da aula de italiano foi dedicada à interações verbais, como podemos notar no seguinte gráfico. 


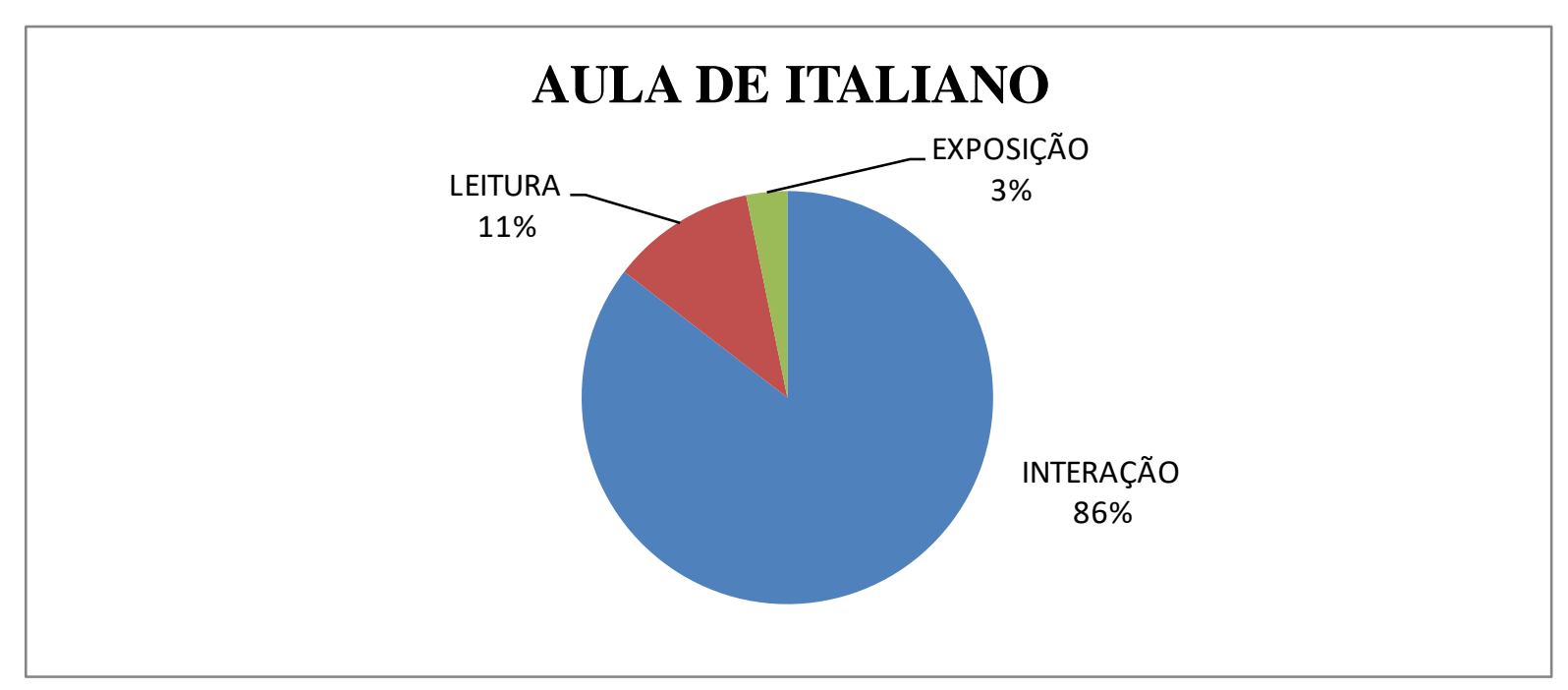

Gráfico 2 - Aula de Italiano

A partir do gráfico, notamos que apenas $3 \%$ do tempo total da aula foi dedicado à exposição de conceitos por parte da professora e que somente $11 \%$ do tempo total da aula foi dedicado à leitura dos textos (na aula de Português o tempo dedicado à essa atividade correspondeu a $46 \%$ do tempo total da aula). Percebemos, portanto, que a maior parte do tempo da aula $(86 \%)$ foi dedicada à interação.

Contudo, é preciso salientar que a interatividade à qual nos referimos se aproxima da noção de dialogismo bakhtiniano, isto é, de qualquer tipo de transmissão oral e não à existência de um diálogo propriamente dito entre professora e alunos. Marcuschi (2005) afirma que diálogo e interatividade não são sinônimos, nas palavras do autor "a interatividade tem a ver com a noção de dialogismo bakhtiniano (uma natural e necessária relação com o outro) e não tanto com a noção de diálogo da Etnometodologia e da Análise da Conversação" (p.46). Desse modo, quando falamos em interação em sala de aula, estamos considerando uma relação verbal entre alunos e professores que ocorreu, na maioria das vezes, por meio de perguntas e respostas breves.

Podemos afirmar que, embora somente $3 \%$ do tempo total da aula tenha sido dedicado à exposição de conceitos por parte da professora, trata-se também de uma aula expositivo-interativa na qual ocorre o domínio da figura da professora e o controle das interações em sala por ela.

Um aspecto interessante de ressaltar é que, embora a interação entre professora e alunos seja assimétrica e aconteça em contexto de instrução formal, a forma de tratamento utilizada tanto na aula de Português quanto na aula de Italiano não é formal. 
A língua italiana contemporânea possui duas formas de pronomes de tratamento no singular, a saber o "tu", familiar e mais informal, e o "Lei ", que demonstra um maior grau de formalidade. De acordo com Brown e Gilman (1960), esse sistema está presente em muitas línguas românicas, como o francês, o espanhol, e pensando diacronicamente, também o latim. Em seu estudo, os autores propuseram os símbolos 'T' e 'V' (das formas latinas "tu" e "vos") para se referir a essas formas de tratamento. Portanto, no caso do italiano, o "tu" seria a forma T e o "Lei", a forma V. Sendo assim, é a forma V que refletiria a assimetria nas interações sociais, caracterizadas por diferenças em relação a poder, idade, posição social etc. Ao contrário do italiano, o português brasileiro não possui um sistema $\mathrm{T} / \mathrm{V}$ forte. As formas de tratamento "você" (T) e "senhor/ senhora" (V) são partes dos usos linguísticos e podem coexistir, isto é, não são utilizadas de maneira rígida e não possuem os mesmos recursos semânticos e pragmáticos que o "tu" e o "Lei" do italiano.

A partir do que foi dito, seria de se esperar o uso da forma V "Lei" na aula de Italiano e o uso tanto da forma $\mathrm{T}$ "você" quanto da $\mathrm{V}$ " a senhora" na aula de Português, mas a expectativa não foi confirmada e nem na aula de Português nem na de Italiano a relação assimétrica foi marcada linguisticamente pela utilização de formas de tratamento formais em sala de aula. No Brasil, em ambiente escolar, o que percebemos é que existe uma maior liberdade de escolha, por parte dos alunos, em relação ao pronome de tratamento, ou seja, é possível escolher entre "senhor/ senhora", para marcar a formalidade e um distanciamento entre professores e alunos, ou também usar "você" para indicar um maior grau de aproximação e, consequentemente, uma maior intimidade.

Sabemos, no entanto, que nessa faixa etária (9-12 anos) a relação entre alunos e professores no Brasil, geralmente, é caracterizada pela informalidade o que parece também acontecer na Itália, embora a idade das crianças que foram gravadas na nossa pesquisa constitua exatamente o limiar e o momento em que os alunos deveriam usar o "Lei" com os professores, enquanto os professores continuam usando o "tu" com os alunos, sublinhando a assimetria da relação. Segundo Kolková (2006)

as crianças, muitas vezes, usam o indistintamente o "tu" com todos os seus interlocutores, mas com o passar do tempo e aumento da idade, aprendem a dirigir-se aos adultos e estrangeiros com o "Lei", enquanto são tratadas sempre por "tu".Um progresso no uso das formas de tratamento ocorre com a idade em ambiente escolar. Enquanto no nível da scuola elementare e secondaria as crianças ou jovens recebem de seus professores o "tu" como forma de tratamento, no 
ambiente universitário a relação entre professor-aluno é marcada reciprocamente pelo uso do "Lei".

[I bambini piccoli danno spesso del tu a tutti quanti, però con la crescente età imparano a rivolgersi verso adulti e stranieri con il Lei, mentre ricevono sempre del tu. Uno sviluppo nell'uso degli allocutivi si svolge con l'età nell'ambiente scolastico. Mentre al livello della scuola elementare e secondaria i bambini o giovani ricevono del tu da parte dei loro insegnanti, nell'ambiente universitario viene nel rapporto insegnante - studente adoperato il Lei reciproco](p.23)

Ter observado também na aula de Italiano que as formas de tratamento utilizadas são informais pode, portanto, indicar que o uso comum em português brasileiro tenha sido estendido ao italiano. A coexistência das duas línguas e dos dois hábitos em relação às formas de tratamento no mesmo espaço e o fato de a escola estar localizada no Brasil podem ser razões que explicam o que foi verificado.

Após a primeira análise, que iniciou sem determinar previamente quais atos de fala seriam analisados, ficou evidente que os mais frequentes eram discordâncias e desaprovações.

As discordâncias, como vimos, se relacionam com o julgamento de uma determinada enunciação com base em uma crença. Nesse sentido, realiza-se um ato em relação à verdade, no qual o falante expõe para o interlocutor as causas e/ou os motivos de sua discordância. Já as desaprovações, relacionam-se com o juízo de verdade e com a exposição de argumentos, mas também com as normas de conduta social e com o exercício do poder.

A seguir, serão tratados separadamente os casos de discordância e os de desaprovação, com o objetivo de mostrar nos exemplos extraídos do corpus, de que maneira eles se apresentam nas duas línguas.

\subsection{DISCORDÂNCIA}

Ao analisarmos os atos de discordância presentes na interação em sala de aula, na relação professor-aluno(s), aluno(s)-professor e aluno(s)-aluno(s), percebemos uma maior presença de estratégias atenuadoras nas discordâncias produzidas em língua portuguesa em relação àquelas produzidas em língua italiana.

Em língua portuguesa, as estratégias mais utilizadas pelos falantes para minimizar o ato de discordar foram: a concessividade (XVII) ; o uso de partículas discursivas e 
expressões de controle e de contato com o interlocutor (XIX) e uso modalizado dos tempos verbais $(V)$.

\subsubsection{Concessividade}

Uma das táticas para atenuar a força da discordância que apresenta maior frequência no corpus de português brasileiro é a concessividade, isto é, a presença, durante a interação verbal, de movimentos concessivos-opositivos que minimizam o risco de um conflito entre os interlocutores. Nas palavras de Haverkate (1994), a concessividade atenua porque viabiliza lançar pelo menos um argumento contra o que se afirma [lanzar por lo menos un argumento contra lo que afirma] (p. 118) e nesse sentido, diminui os possíveis efeitos negativos de um desacordo total expresso de modo direto.

Para que possamos entender como essa estratégia foi utilizada nos atos de discordância realizados em língua portuguesa e em língua italiana na interação em sala de aula, apresentamos abaixo alguns exemplos.

O primeiro fragmento, extraído da aula de Português, retrata um diálogo entre professora e alunos, sobre o capítulo 30, do livro O Gênio do Crime, de João Carlos Marinho.

\section{FRAGMENTO DIS-PT n ${ }^{0} 1$}

Prof PORT: então gente o::: a gente tá vendo tudo isso que tá acontecendo aqui ... tá acontecendo lá na FÁbrica o gordo sendo tortuRAdo pressioNAdo então aqui o que que ele vai fazer ele vai nos explicar como é:: que as pessoas que conviviam com o gordo e tavam envolvidas na investigação estavam Agindo... essa é a notícia de que o gordo SUMIU então como é que o Mister tá usando seus métodos para descobrir aonde ele foi quem levou, né? ele tem uma pista muito simples que é o carro e um nome, que era um nome falso, onde será que ele foi que ele conseguiu a lista de donos de fusca bordô? onde cês acham que é esse lugar? ONDE PODERIA ser na verdade?

$C$ : naquele lugar

Fo: maquininha de fotocópia...

Prof PORT: então mas AOnde? ele foi ao DEPARTAMENTO da cidade... que que seria esse departamento da cidade? QUAL departamento seria esse?

Nesse trecho, a professora retoma alguns acontecimentos da narrativa, a fim de verificar se os alunos haviam entendido tudo o que havia sido lido e discutido até aquele momento. Então, ela pergunta o nome do local em que o personagem do Mister teria ido para conseguir a lista com o nome de todos os donos de carro fusca de cor bordô daquela cidade. $\mathrm{O}$ aluno Fo responde que o personagem conseguiu a lista na máquina de xerox (maquininha de fotocópia). A professora, valorizando a participação do aluno em sala de aula, evitou dizer de 
forma direta que a resposta dele estava incorreta e, ao invés disso, preferiu discordar dele de forma parcial e atenuada, realizando um movimento concessivo-opositivo ao dizer então mas AOnde?

Ao utilizar a palavra "então" é como se a professora dissesse "ok, eu considero essa informação", de fato, o personagem após ter conseguido a lista havia feito cópias dela. No entanto, não era essa a informação que a professora havia pedido, ela queria saber o nome do lugar onde estava a lista, por isso, acrescentou novamente a pergunta "mas aonde?". Dessa forma, observamos que a utilização do movimento de concessão-oposição (então-mas) atenuou a força ilocucionária da discordância.

Ao suavizar o ato da discordância, a professora foi, ao mesmo tempo, cortês com o aluno, pois evitou que sua enunciação pudesse ameaçar à face positiva de Fo, uma vez que ele poderia se sentir envergonhado diante dos colegas, por ter fornecido uma resposta errada. Sobre a ameaça à face, Goffman (2011 [1967]) escreve:

\begin{abstract}
se ela (pessoa) sentir que está com a face errada, ou fora de fachada, provavelmente se sentirá envergonhada e inferior devido ao que aconteceu com a atividade por sua causa e ao que poderá acontecer com sua reputação enquanto participante. Além disso, ela pode se sentir mal porque esperava que o encontro apoiasse uma imagem do eu à qual ela se sente emocionalmente ligada e que agora encontra ameaçada. Uma falta de apoio apreciativo percebida no encontro pode chocá-la, confundi-la e momentaneamente incapacitá-la enquanto participante da interação. Seus modos e orientação podem cambalear, desabar e desmoronar. Ela pode ficar constrangida e mortificada; ela pode ficar com a fachada envergonhada [shamefaced]. ( p.18)
\end{abstract}

Além disso, ao escolher atenuar a força ilocucionária do ato de discordância, a professora preservou a relação harmoniosa entre ela e o aluno em sala de aula, não inibindo e até, de certa forma, estimulando a continuação da participação dele na discussão sobre a narrativa.

No próximo fragmento, diferentemente do anterior, que retratou uma discordância realizada pela professora em relação à resposta de um aluno, observamos uma discordância expressa por um aluno em relação à fala da professora.

\title{
FRAGMENTO DIS-PT n ${ }^{\circ} 2$
}

Prof PORT:: NOSSA mas ele não gostava de UÍSque?

$L$ : sim mas ele bebeu muito 
Prof PORT:: será?

$R a$ : não é muito

Prof PORT: estranho né?

Essa interação, que aconteceu entre falantes nascidos no Brasil, ocorreu após a leitura de um trecho do livro no qual o personagem do Mister, que gostava muito de beber uísque, depois de ter ingerido um gole da bebida, imediatamente, colocou-a para fora. Nesse instante, a professora falou para a classe NOSSA mas ele não gostava de UíSque? O aluno L aparentemente deu razão à professora dizendo sim, o personagem gostava de uísque, porém, em seguida, acrescentou mas ele bebeu muito. Percebemos, nesse momento, que o aluno não concordou totalmente com a professora e atenuou sua discordância por meio de um movimento de concessão-oposição (sim-mas). Em outras palavras, o aluno L discordou parcialmente, porque, na opinião dele, o personagem teria cuspido o uísque, não porque não gostasse da bebida, mas porque talvez tivesse bebido em demasia e se engasgado.

Desse modo, podemos notar que a presença do "sim-mas" suaviza o desacordo realizado pelo aluno. Ao mesmo tempo, a presença dessa tática permite não colocar em risco a face positiva da professora, que poderia se sentir contestada desnecessariamente, o que poderia gerar uma tensão na relação aluno-professor.

O próximo fragmento que apresentaremos, retrata o momento da aula, em que durante a leitura da narrativa $O$ Gênio do Crime apareceu a palavra xaveco. A professora quis verificar o conhecimento das crianças sobre o significado daquele termo e fez a seguinte pergunta para a classe:

\section{FRAGMENTO DIS-PT n $^{0} 3$}

Prof PORT: QUE QUE é xaveco gente?

$C$ : XAVECO eu acho que eu sei é aquele CArinha da turma da Mônica

Prof PORT: ah é também mas se fosse seria escrito com letra maiúscula tá C? porque aí seria o NOme do personagem

De início, observamos que a professora não escolhe nenhum aluno em particular e faz a pergunta para todos os alunos da classe. Assim, os alunos têm liberdade para decidirem se querem responder ou não. A aluna $\mathrm{C}$ escolhe espontaneamente responder e arrisca de forma tímida e atenuada uma resposta. A aluna começa sua enunciação de forma atenuada, fazendo uso de uma construção verbal que expressa opinião em forma de dúvida eu acho que eu sei é aquele carinha da turma da Mônica. Briz \& Albelda (2013) escrevem que, muitas vezes, não 
é fácil para o analista distinguir se o uso da expressão "eu acho que" representa uma dúvida real ou se trata de uma dúvida "fingida". Nas palavras dos autores:

Podem surgir problemas na hora de decidir o caráter atenuador de algumas
formas de dúvida ou possibilidade (acho que, talvez, poder) ou opinião (eu
acho). Nesses casos, o analista deve decidir se trata de uma dúvida real sobre
algo que afeta o estado de coisas ou se é uma dúvida simulada [...] Na
declaração com dúvida fingida, que não é dúvida, senão atenuação auto
protetora do eu-falante, que evita assim a responsabilidade pelo que é dito.
[Pueden surgir problemas a la hora de decidir el carácter atenuante de
algunas formas de duda o possibilidad (me parece, a lo mejor, poder) o de
opinion (yo creo). En estos casos, el analista debe decidir si se trata de una
duda real sobre algo que afecta al estado de cosas o si es una duda
simulada [...] A la declaración con duda fingida, que ya no es duda, sino
atenuación auto-protectora del yo-hablante, que evita así la responsabilidad
sobre lo dicho.] ( p. 299-300)

Podemos inferir que, nesse caso, se trata de uma dúvida fingida, porque a partir do contexto situacional brasileiro, supomos que a aluna não tinha dúvidas reais em relação ao fato de "xaveco" ser o nome de um personagem da Turma da Mônica, uma vez que as histórias em quadrinhos fazem parte do universo infantil e, em particular, as histórias da Turma da Mônica são as que fazem mais sucesso entre as crianças em âmbito nacional. Portanto, a aluna $\mathrm{C}$ poderia não estar segura em relação à palavra "xaveco" presente na narrativa corresponder a "xaveco" nome do personagem da história em quadrinhos, por esse motivo optou por usar uma expressão de dúvida fingida. A escolha da estratégia atenuadora revela a intenção da aluna de se auto proteger, isto é, de velar pela sua própria imagem, e de reduzir o seu compromisso com o enunciado (BRIZ \& ALBELDA, 2013, p.300). De fato, como a aluna $\mathrm{C}$ não se sentia segura em relação à sua resposta, preferiu arriscar-se, de forma cautelosa, demonstrando preocupação com sua própria face.

Quando a atenuação é usada com o objetivo do falante se auto proteger, ela não pode ser considerada como uma forma de cortesia verbal, pois esta pressupõe uma forma de comportamento em sociedade, isto é, na relação dialógica entre os seres humanos. Realiza-se cortesia quando se realiza algo que afeta o interlocutor, o outro, e não o próprio falante. Briz \& Albelda (2013) escrevem que, "às vezes, haverá atenuação do falante e, portanto, a estratégia terá um caráter mais monológico; outras vezes, existirá a atenuação de falante e do ouvinte e, portanto, apresentará um caráter mais dialógico e às vezes cortês". [ unas veces, habrá atenuación de hablante y, por tanto, la estrategia tendrá un carácter más monológico; 
otras, atenuación de hablante y oyente y, por tanto, tendrá un carácter más dialógico y a menudo cortés.] (BRIZ \& ALBELDA, 2013, p. 292).

$\mathrm{Na}$ sequência, a professora considera a colocação da aluna, porém, discorda da resposta fornecida por ela. Na enunciação da professora, observamos uma discordância realizada de forma cortês e atenuada, na qual existe a preocupação em minimizar os efeitos da ameaça a face positiva da aluna. A professora utiliza um movimento concessivo-opositivo que, após considerar parcialmente a resposta de $\mathrm{C}$, a nega, explicando porque estaria incorreto $\boldsymbol{a h} \boldsymbol{e}$ também mas se fosse seria escrito com letra maiúscula tá C? porque aí seria o NOme do personagem. Em outras palavras, a professora concorda que "xaveco" também é o nome de um personagem da Turma da Mônica, mas ressalta que, se o texto se referisse a ele, o nome próprio do personagem estaria grafado com letra maiúscula.

Podemos perceber que a concessividade não é o único procedimento que a professora utiliza para minimizar a força ilocucionária da discordância: ela emprega também o tempo verbal no condicional no lugar do presente ah é também mas se fosse seria escrito com letra maiúscula tá C? porque aí seria o NOme do personagem. A professora, ainda, chama a aluna pelo nome, estabelecendo, assim, uma relação de proximidade com ela. E por fim, emprega uma partícula descritiva de contato com o interlocutor, solicitando o consentimento da aluna C para poder prosseguir com a aula ah é também mas se fosse seria escrito com letra maiúscula tá $\boldsymbol{C}$ ? Todos esses recursos utilizados pela professora evidenciam seu cuidado na relação com os alunos, que tenta evitar ao máximo colocar em risco suas faces positivas (o desejo de ser aprovado, por isso valoriza a resposta fornecida mesmo não concordando totalmente com ela) e negativas (o desejo de privacidade, por isso evita impor uma pergunta para um determinado aluno, preferindo fazê-la de forma geral para todos).

Sobre a relação entre cortesia e atenuação, Briz (2004) escreve

Independentemente da situação, a avaliação da cortesia parece ser medida pela maior ou menor presença de atenuadores, assim como pela força destes. Portanto, mais presença de atenuadores e/ou maior força de qualquer deles se entende que a força ilocucionária, o grau de imposição, de intensidade obrigatória é menor e, assim, por conseguinte, existe um maior grau de cortesia.

[Al margen de la situación, la evaluación de la cortesía parece medirse según la presencia mayor o menor de atenuantes, a sí como por la fuerza de éstos. Por tanto, a más presencia de atenuantes y/o a mayor fuerza de alguno de estos, se intiende que la fuerza ilocutiva, el grado de imposición, de intensidad obligativa es menor y, asì pues, hay mayor grado de cortesia] ( p. 76) 
Assim, a professora, ao utilizar vários procedimentos atenuadores, assumiu um comportamento cortês perante os alunos, demonstrando a valorização das relações interpessoais em sala de aula. Fato que, por sua vez, favorece a criação de um ambiente agradável e propício para a participação dos alunos e, consequentemente, para o sucesso do processo de ensino-aprendizagem.

Outro exemplo da utilização da tática atenuadora da concessividade, na realização de uma discordância na aula de Português, ocorreu entre os alunos L e F. No fragmento transcrito a seguir, podemos notar que o aluno F não concordou com a versão dos fatos que seu colega de classe, o aluno L, estava fazendo sobre a narrativa e afirmou que ele tinha se equivocado em um pequeno detalhe:

\section{FRAGMENTO DIS-PT $n^{\circ} 4$}

$L$ : é.. ele falou pra... eles foram pra um escritório aí o Bolachão o Bolacha sentou numa cadeira aí os dois... os dois caras ficaram atrás dele o Anão pegou quatro almofadas para poder ficar na altura da mesa e ele disse que não ia contar aí ele pediu para um dos caras ir comprar um misto quente

$F$ : um sanduíche sanduíche aí depois teve que comprar um misto quente

$L$ : aí, tá.. é...o cara foi voltou aí o Anão disse agora conta e ele não

Enquanto L narrava os fatos, F interveio e discordou do seu colega, afirmando que primeiro, o personagem mandou os "caras" irem comprar um sanduíche, mas como o Bolachão queria um misto quente, então o personagem pediu para comprar um misto quente. Nessa interação, que aconteceu entre alunos nascidos no Brasil, notamos que ocorreu também uma discordância parcial, isto é, o aluno F discordou parcialmente do aluno L através de um movimento opositivo-concessivo um sanduíche sanduiche aí depois teve que comprar um misto quente. Observamos que $\mathrm{F}$, para demonstrar que não concordava totalmente com o colega, fez uso de uma estratégia atenuadora, introduzindo, primeiramente, a informação que considerava correta e, depois, utilizando um movimento concessivo para aceitar a informação de L.

Interessante notar que discordância e correção ocorrem primeiro e que, logo em seguida, há a concordância. Deste modo, vemos uma inversão do movimento, pois, nos demais fragmentos apresentados, a direção do movimento era de concessão e posterior oposição, enquanto no exemplo que acabamos de ver percebemos um movimento de oposição e posterior concessão. 
A função que essa estratégia adquire, usada dessa maneira e dentro desse contexto, é a de reparar uma ameaça à face positiva de L, que havia sido corrigido por F diante dos demais alunos da sala. Essa função reparadora, segundo Albelda et al. (2014) "ocorre quando se produziu o dano ou problema nas relações interpessoais e o mesmo falante que o causou ou outro, repara esse dano recorrendo à atenuação. [tiene lugar cuando ya se ha producido el daño o problema en las relaciones interpersonales y, bien el mismo hablante que lo ha causado, bien otro, reparan ese daño acudiendo a la atenuación.] (p.11).

Desse modo, o aluno $\mathrm{F}$ recorreu à atenuação para reparar a ameaça à face positiva do amigo, que poderia se sentir desconfortável com a discordância e constrangido com a correção em público. Assim, através da reparação, F demonstrou, amistosamente, seu desejo de colaborar com o amigo, ajudando-o a re-contar a narrativa e, não o criticando por haver se esquecido de um detalhe.

No próximo fragmento, apresentamos uma dupla discordância, realizada pelo aluno $\mathrm{R}$ em relação à professora e pela professora em relação ao aluno R. Ambas as discordâncias foram realizadas, diminuindo a força ilocucionária por meio da utilização do recurso da concessividade.

\section{FRAGMENTO DIS-PT $\mathbf{n}^{\circ} 5$}

Prof PORT: o detetive:: o invicto né? se alguém vai descobrir alguma coisa aí...vai ser ele né gente?[ Não tem essa fama à toa

$R$ : mas não vai ser ele

Prof PORT: será que não?

$R$ : não eu tenho certeza ((com tom doce))

(( a professora coloca os óculos e olha para o livro ))

Prof PORT: vamos lá então gente página 103 a gente vai fazer uma ordem vamos seguindo assim

No trecho acima, observamos que o aluno $R$ não concordou com a afirmação da professora de que o detetive invicto iria descobrir onde o personagem do Bolacha estava (Bolacha havia desaparecido na narrativa) e, então, expressa sua discordância utilizando um movimento concessivo-opositivo que se manifesta na expressão mas não vai ser ele. O aluno $\mathrm{R}$ poderia ter dito apenas "não vai ser ele", porém escolheu atenuar sua discordância acrescentando o conector "mas" que funciona, nesse contexto, como se dissesse "ok, eu sei que ele é invicto, mas não será ele quem vai descobrir". Dessa maneira, o aluno considera que o personagem é um ótimo detetive (invicto porque não deixou nenhum caso sem resolução), mas discorda do fato de ser ele quem descobrirá o paradeiro do Bolacha. A utilização de uma 
tática que minimiza a força ilocucionária do ato da discordância, demonstra a preocupação do aluno em não colocar em risco a face positiva da professora, ao não concordar totalmente com o enunciado dela.

A professora, ao ouvir a opinião do aluno, exprime indiretamente sua discordância, por meio de uma pergunta que suscita dúvida e diz será que não? Durante a formulação da pergunta, a professora mudou a entonação da $\mathrm{voz}^{8}$, suavizando-a e empregou a modalização do tempo verbal do presente para o futuro de probabilidade, fato que atenuou ainda mais sua discordância. Aliás, a expressão "será que" é uma formúla dubidativa e sempre aparecerá no futuro.

A rede de inferências que nos permitiu entender a pergunta da professora como uma discordância indireta baseia-se na suposição de que a professora já havia lido o livro e, portanto, sabia qual era o personagem que descobriria onde Bolacha estava.

Notamos que professora e aluno discordam mutuamente um do outro expressando-se com cortesia, fazendo uso de táticas atenuadoras que previnem ameaças à imagem dos interlocutores e evitam conflitos interacionais. Interessante destacar que a professora dá liberdade para que os alunos possam emitir suas opiniões e demonstra paciência quando eles manifestam opiniões diferentes das suas. Isso revela respeito com os alunos e consciência de que é necessário tempo para que o aprendizado aconteça. Mesmo ao final da interação, quando R insiste e discorda mais uma vez da professora, de forma direta e sem a utilização de atenuadores, dizendo não eu tenho certeza, a interação não fica prejudicada e a professora segue com a aula sem que haja nenhum sinal de tensão.

O próximo fragmento, reproduz uma discordância da professora, originada a partir de uma dúvida do aluno $\mathrm{R}$ em relação à data de invenção do telefone e do celular. Nesse momento, o aluno havia perguntado para a professora como seria possível existir uma fábrica e não existir celular. Depois de um breve debate, a professora disse:

\section{FRAGMENTO DIS-PT n ${ }^{\circ} 6$}

Prof PORT: AS FÁbricas de tecido ... são uma invenção ... do século dezoito do século dezenove... primeiro surgiram as fábricas... e o celuLAR só pode surgir agora recentemente há pouco mais de 15 anos por conta da:: revolução da tecnologia... então as pessoas se vestiam antes os carros exisTIam:: não é? a energia elétrica surgiu no início do século... vinte

\footnotetext{
${ }^{8}$ Não conseguimos marcar a entonação utilizada pela professora na transcrição, de maneira adequada, por falta de recursos gráficos. Não foi uma entonação enfática e sim branda, doce. Desse modo, optamos por colocar entre parênteses a descrição.
} 
$R$ : mas é que eu pensei... ahn... se existiam as FÁbricas existia já um telefone Prof PORT: MAS O TELEFONE EXISTE... o:: Bolacha não ligou para o gerente?

$R$ : ENTÃO? ((fez um gesto de confirmação com os braços abertos $)$ )

Prof PORT: não o celular ... existia o telefone

Após a explicação da professora sobre o surgimento recente do celular, o aluno $\mathrm{R}$ quis esclarecer o motivo da sua dúvida e disse mas é que eu pensei... ahn... se existiam as FÁbricas existia já um telefone. A professora então concordou com $\mathrm{R}$ e disse MAS $O$ TELEFONE EXISTE... o:: Bolacha não ligou para o gerente? Nesse momento, o aluno abriu os braços e falou ENTÃO? Como se quisesse dizer: " isso justifica minha dúvida, se existiam as fábricas, existia o telefone, tanto que o Bolacha ligou para o gerente, como pode então o celular ser uma invenção recente?" O aluno não diz isso verbalmente, mas a professora parece entender seu raciocínio e a relação que ele estabeleceu entre os fatos e disse não o celular ... existia o telefone.

Notamos que tanto o aluno, no momento em que justifica sua dúvida, quanto a professora, quando discorda da relação que ele estabeleceu mentalmente entre os fatos, fizeram uso da tática atenuadora da concessividade para se expressarem. $\mathrm{O}$ aluno $\mathrm{R}$, ao dizer mas é que eu pensei... demonstra ter acolhido a explicação da professora, mas aparenta não estar muito convencido, no entanto, não gostaria de ameaçar a face positiva da professora afirmando que ela estava equivocada e colocando em dúvida o valor social positivo e a autoridade que a ela é dada pelo seu papel. A professora, por sua vez, percebe que quem está equivocado, pelo menos parcialmente, é o aluno $\mathrm{R}$ e assim escolhe atenuar sua discordância através de um movimento de concessão seguido de uma oposição à afirmação $\boldsymbol{M A S} O$ TELEFONE EXISTE... o:: Bolacha não ligou para o gerente?, que ela expressa dizendo: não o celular ... existia o telefone.

Em ambos os enunciados é possível observar uma preocupação em não ameçar a imagem do interlocutor, isto é, de não afirmar categoricamente que as convicções de um ou de outro estavam equivocadas. Ao invés disso, ambos preferiram atenuar seus enunciados tornando-os mais corteses e educados, mantendo e preservando assim o equilíbrio das relações interpessoais em sala de aula.

Em seguida, transcrevemos a continuação do diálogo entre aluno e professora. Neste fragmento, o aluno $\mathrm{R}$ revela que não sabe a diferença entre o telefone fixo e o celular. Então a professora, com a interferência do aluno Fo, vai diferenciar os dois. 


\section{FRAGMENTO DIS-PT n 7}

Prof PORT: você não SABE a diferença do fixo e do celuLAR?

$R$ : não não faço a menor ideia

Prof PORT: você tem telefone fixo na sua CAsa?

$R$ : ahn::: fixo fixo não

$R a$ : R o fixo é o de casa

Prof PORT: não pera só um pouquinho ... o fixo você TEM um telefone que fica DENtro da sua casa?

$R$ : que CArrega dentro de casa sim

Prof PORT: isso chama-se telefone fixo porque você não pode tirar ele da sua casa pra falar em outro lugar ... PORQUE R... ele é conectado a:: uma rede de transmissão e ele só vai funcionar dentro da sua casa... EXISTE um CABO que vai fazer a ligaÇÃO pra ele funcionar DENtro da sua casa

Fo: se tirar aquele telefone ele funciona

Prof PORT: não mas fora do raio de ação da BAse... ele não funciona tá?

$R$ : mas o meu não tem cabo

Prof PORT: ele ESTÁ conectado na base do seu telefone

$R$ : então mas ele não tem CAbo o meu fixo

Prof PORT: tem que ter $\mathrm{R}$

$R$ : não TEM CABO

Fo: ah:: é aquele lá

Prof PORT: R ele ESTÁ conectado à base do seu telefone... você chega em casa hoje e vai olhar

$R$ : sim não tem cabo posso ir até meu quarto

Fo: é esse aqui:: ((faz um gesto com a mão indicando o tamanho do aparelho, mas $R$ não pode ver porque Fo está sentado atrás dele))

Prof PORT: você leva uma PARTE dele R

$R$ : não entendi ainda

Prof PORT: você CARREGA na sua casa uma PARTE DELE a outra parte você tem que por pra carregar numa base... não tem?

$R: \operatorname{sim}$

No trecho acima, após a professora ter explicado que o telefone fixo é aquele que fica dentro de casa e que, se retirado de casa, não funciona, o aluno Fo diz para a professora se tirar aquele telefone ele funciona, Fo fazia referência ao telefone fixo com aparelho sem fio que, quando retirado da base, funciona e a pessoa pode caminhar com ele pela casa. A professora discorda do aluno e diz não mas fora do raio de ação da BAse... ele não funciona tá? O que a professora queria dizer é que não dava para sair na rua com ele, como com o celular, porque fora do raio de ação dele, o telefone não funcionaria. Mais uma vez, notamos uma discordância atenuada por meio da concessividade, na qual a professora aceita o que Fo disse sobre tirar a parte móvel do telefone fixo para ele funcionar, mas não concorda que, se retirado de casa, ele funcione.

Nesse instante, o aluno R discorda da explicação da professora de que existiria um cabo dentro de casa que faz o telefone fixo funcionar e diz mas o meu não tem cabo. Intuimos que o aluno se referia à existência de um cabo que ligasse a base do telefone à parte móvel, usada para falar (aparelho de telefone fixo com fio). A professora afirma: ele está 
conectado na base do seu telefone. Em outras palavras, o que a professora queria dizer é que mesmo não havendo cabo visível dentro de casa, o telefone (parte móvel) estava conectado a base (parte fixa) para ele poder funcionar. $\mathrm{R}$ insiste, afirmando então mas ele não tem CAbo o meu fixo.

Desse modo, o que vemos até aqui, são três discordâncias consecutivas, realizadas de maneira atenuada por meio de três movimentos concessivos-opositivos, um realizado pela professora não mas fora do raio de ação da BAse... ele não funciona tá? e os outros dois pelo aluno R mas o meu não tem cabo / então mas ele não tem CAbo o meu fixo.

A utilização da conjunção adversativa "mas" minimiza, nesse contexto, a discordância, abrindo caminho para a introdução de uma opinião contrária à do interlocutor. A professora poderia ter dito somente "não, fora do raio de ação da base ele não funciona tá? $\mathrm{O}$ mesmo podemos verificar na fala do aluno que poderia ter dito simplesmente "o meu não tem cabo". Na segunda discordância realizada por R, o aluno introduz um "então", indicando que considera a opinião da professora, mas que não concorda com ela. Esse movimento concessivo-opositivo, como vimos, minimiza a ameaça à face positiva dos interlocutores entendida como:

[...] desejo de que a auto-imagem seja aprovada e valorizada. É o desejo de aprovação social; refere-se à necessidade que todo indivíduo tem de ser aceito, de ser tratado como membro de um grupo, de saber que seus próprios desejos são compartilhados pelos interlocutores. Representa o desejo de ser apreciado e admirado e que seus desejos sejam aceitáveis pelo interlocutor. Ressalta-se que, em geral, os indivíduos querem ser amados, compreendidos e valorizados. (SILVA, 2008, p. 179)

Verificamos, desta maneira, como a cortesia verbal se faz presente na sala de aula durante a aula de Português, na produção de atos que colocam em risco a imagem dos falantes, como é o caso da discordância. A cortesia verbal, evidenciada pelo uso de estratégias atenuadoras existentes tanto nas relações entre professora e alunos quanto entre alunos e professora e, também, entre os próprios alunos, revela a participação que cada um deles tem na construção e na manutenção das relações em sala de aula, as quais, por sua vez, contribuem para criar um contexto favorável de ensino e aprendizagem.

No último fragmento da aula de Português em que encontramos a presença da concessividade agindo como recurso atenuador de uma discordância, a professora pergunta para os alunos se eles conheciam a lista telefônica e o guia de ruas da cidade. Abaixo, apresentamos um trecho da interação: 


\section{FRAGMENTO DIS-PT $n^{\circ} 8$}

Prof PORT: I::sso você já viu uma lista telefônica?

((alguns alunos respondem que sim e outros que já))

Prof PORT:o que que ela CONTÉM?

Fo: ela tem o número de telefone As ru::as... número de telefone das pessoas

Prof PORT: das pessoas exato i::sso então ela é um catálogo um livro que tem o NOme do dono da

LInha telefônica endereço e o número de telefone ... ele procurou lá não achou QUE outro lugar ele procurou?

Fo: no mapa da cidade

Prof PORT: no GUIA da cidade alguém aqui já viu o guia da cidade de São Paulo?

Fo: $\operatorname{sim}$

Prof PORT: o guia de RUAS?

((Classe fica em silêncio))

Prof PORT:: Não?

Fo: eu sim eu já

Prof PORT: comé/ que ele é?

Fo: ele é tipo uma coisa assim ((abre os braços e faz um quadrado no ar))

$B$ : é tipo um quaDRADO tem todas as ruas os nomes

Prof PORT: não... o guia de ruas é um LIvro você pode ter visto um MApa tá?

((B balança a cabeça afirmativamente $))$

Notamos que, quando a professora pergunta para os alunos quem já tinha visto um guia de ruas e como ele era, o aluno B, tentando completar o que seu colega Fo tinha começado a dizer gestualmente, responde é tipo um quaDRADO tem todas as ruas os nomes. Nesse momento, a professora discorda dele dizendo não... o guia de ruas é um LIvro você pode ter visto um MApa tá? Observamos, no início da enunciação da professora, que ela discorda rapidamente do aluno, mas, em seguida, atenua sua fala acrescentando a possibilidade de o aluno ter visto um mapa e tê-lo confundido com um guia de ruas.

Percebemos, assim, um movimento opositivo-concessivo, no qual a professora discordou da afirmação do aluno, tirando-lhe a razão, mas devolvendo-a em parte, logo depois, ao fazer uma concessão e considerar que ele poderia ter visto algo parecido, mas que não se tratava, propriamente, de um guia de ruas, mas talvez de um mapa. Assim sendo, a professora atenuou sua discordância tardiamente, fazendo um movimento de reparação ao dano causado à face positiva do aluno. Em outras palavras, a professora identificou a possibilidade do aluno se sentir desvalorizado ao ouvir a discordância de modo direto e não atenuado e, assim, escolheu reparar um possível dano oferecendo uma possibilidade de interpretação para a descrição que o aluno havia fornecido sobre o guia de ruas. Novamente, podemos notar o esforço da professora para manter o equilíbrio nas relações em sala de aula e para alcançar o sucesso do processo de ensino e aprendizagem. 
Já nas aulas de Italiano, a utilização da atenuação nos atos de discordância não foi tão frequente como na aula de português e a concessividade, como procedimento atenuador, foi encontrada apenas duas vezes em nosso corpus de atos de discordância. Apresentaremos, a seguir, os dois fragmentos em que foi possível identificar a utilização dessa tática. O primeiro deles retrata um momento da aula em que a professora falava sobre os direitos das crianças e perguntou para a classe para quais tipos de crianças esses direitos haviam sido criados.

\section{FRAGMENTO DIS-IT n ${ }^{0} 1$}

Italiano

Prof IT: un bambino... e C'ERANO situazioni in cui uCCI-de-va-no.. e noi stiamo parLANdo diciamo dell' impero romano un po' prima ma in realtà era ancora una pratica perché o::: questo dobbiamo pensare anche a un'altra cosa aspettate questo.. questi diritti sono stati scritti per QUALI bambini ?

$M$ : i bambini piccoli

Prof IT: no ok brasiLIAni itaLIAni ameriCAni?

Classe: DI TUTTO IL MONDO
Tradução

Prof IT: um menino... e EXISTIAM situações nas quais mA-TA-vam... e nós estamos faLANdo digamos do império romano um pouco antes mas na verdade era ainda uma prática porque o::: isto devemos pensar também em uma outra coisa esperem isso... esses direitos foram escritos para QUAIS crianças?

$M$ : para as crianças pequenas

Prof IT: não ok brasiLEIras itaLIAnas

ameriCAnas?

Classe: DE TODO O MUNDO

Notamos que, após a pergunta da professora, a aluna $\mathrm{M}$ responde que os direitos infantis haviam sido escritos para as crianças pequenas, então, a professora imediatamente discorda dizendo que não. Mas, logo, repensa e considera a resposta da aluna falando no ok . Em seguida, a professora reformula sua pergunta brasiLIAni itaLIAni ameriCAni? Assim, identificamos a presença de um movimento opositivo-concessivo, já que, após uma discordância inicial, ocorreu uma concessão, aceitação.

O movimento de concessividade atenuou a discordância expressa de modo direto pela professora utilizando o advérbio "no" ao reparar a ameaça à face positiva da aluna que poderia se sentir desvalorizada e envergonhada diante dos colegas, por ter fornecido uma resposta considerada incorreta pela professora. Desse modo, a professora, ao levar em consideração a resposta da aluna e reformular sua pergunta, acrescentando dados que poderiam conduzir tanto a aluna $\mathrm{M}$ como o restante dos alunos a fornecerem a resposta esperada por ela, agiu de forma cortês, demonstrando cuidado na relação interpessoal em sala de aula e, ao mesmo tempo, estimulando a participação dos demais alunos na interação. 
Em outro momento da aula de italiano, a classe, motivada pela leitura da poesia, discutia sobre o direito das crianças de serem ouvidas. A professora retomou, então, uma fala do aluno $\mathrm{S}$ :

\section{FRAGMENTO DIS-IT $n^{\circ} 2$}

Italiano

IT: ASCOLTATI ERA PROPRIO.. QUELLO CHE DICEVA S VERO S ?

((S fa un segno affermativo con la testa))

Prof IT: ma non si sente ascolTAto...quando ti SENTIresti ascoltato dagli altri $\mathrm{S}$ ?

$S:$ così

Prof IT: così come? MA IO TI SENTO se vieni qua da me e mi dici MAESTRA posso andare in bagno? ti dico di sì allora

Fo: no ascoltato nel senso... non nel senso di ascoltare ti ascoltano pure ma non:....

\section{$T$ : TI CREDONO}

Fo: uno non ti crede o non:: ...

Prof IT: non dà il valore giusto

Fo: è non dà il valore a quello che dici

Prof IT: AH::::

\section{Tradução}

AQUILO QUE S DIZIA NÉ S?

((S faz um gesto afirmativo com a cabeça $)$ )

Prof IT: mas não se sente ouVIdo... quando você se SENTIria ouvido pelos outros S?

$S:$ assim

Prof IT: assim como? MAS EU TE OUÇO se você vem até mim e me diz PROFESSORA eu posso ir ao banheiro? eu te digo sim então

Fo: não ouvido no sentido... não no sentido de ouvir te ouvem mas não::...

$T$ : ACREDITAM EM VOC $\hat{\mathbf{E}}$

Fo: não acreditam em você ou não:: ...

Prof IT: não dão o justo valor

Fo: é não dão valor àquilo que você diz

Prof IT: AH:::

A professora iniciou relembrando que o aluno $\mathrm{S}$, em um momento anterior da aula, havia feito um comentário sobre o fato de não se sentir ouvido pelos adultos. Nesse instante, então, ela aproveitou para lhe perguntar em que ocasião e de que modo ele se sentiria ouvido. $\mathrm{S}$ respondeu com um così [assim], ou seja, como a professora estava fazendo naquele momento, dando-lhe a oportunidade de falar e ouvindo-o. Então a professora disse MA IO TI SENTO se vieni qua da me e mi dici MAESTRA posso andare in bagno? ti dico di sì allora [MAS EU TE OUÇO se você vem até mim e me diz PROFESSORA eu posso ir ao banheiro? eu te digo de sim então].

O enunciado da professora possibilita duas interpretações dentro desse contexto. A primeira é a de que a professora discorda, de fato, do aluno, pois considera que ela o ouve. Já a segunda, é a de que a professora, discorda, aparentemente, do aluno mas com isso seu objetivo é estimulá-lo a refletir e a expressar sua opinião sobre o que ele considera ser ouvido. $\mathrm{Na}$ discordância (efetiva ou aparente) da professora, se faz presente um recurso atenuador, a impessoalização. Segundo Albelda et al (2014)

(...) a impersonalização refere-se aos casos em que se impersonaliza através de uma citação. Se recorre a uma citação literal de outra pessoa, ao acervo 
comum (um provérbio, por exemplo) ou a uma citação de si mesmo para justificar ou introduzir a opinião de maneira menos comprometida, como se se tratasse de uma voz alheia.

[(...) la impersonalización recoge los casos en que se impersonaliza a través de la cita. Se recurre a una cita literal de otra persona, al acervo común (un proverbio, por ejemplo) o a la cita de uno mismo para justificar o introducir la opinión de manera menos comprometida, como si se tratara de una voz ajena.] (p. 21-22)

Desse modo, percebemos que a professora usa as palavras do próprio aluno, quando ele lhe pede permissão para ir ao banheiro, para que fique claro que ela o ouve, isto é, através da citação das palavras ou do pensamento de outra pessoa (o aluno), a professora justifica sua opinião de maneira menos comprometida.

Nesse instante, o aluno Fo discorda da fala da professora e, tenta explicar, dizendo no ascoltato nel senso... non nel senso di ascoltare ti ascoltano pure ma non:... [não ouvido no sentido... não no sentido de ouvir te ouvem mas não:...] Desse modo, Fo afirma que não se trata de se sentir ouvido no sentido de, simplesmente, ouvir, porque ouvir os adultos ouvem, mas no sentido de que os adultos não acreditam nas crianças, sentido que é completado pela intervenção do aluno T que diz TI CREDONO [ACREDITAM EM VOC $\hat{E}$ ]. Assim, não sentir-se ouvido refere-se ao fato de que os adultos não acreditam naquilo que as crianças dizem.

Desse modo, notamos que o aluno Fo, ao expressar discordância em relação ao que a professora havia falado, atenua o seu ato de fala, fazendo uso de um movimento concessivo, no qual dá razão para a professora dizendo ti ascoltano pure [ouvir eles te ouvem] e, em seguida, acrescenta uma adversativa ma non:... TI CREDONO [mas não:... ACREDITAM EMVOCE].

É interessante notar que essa interação ocorreu entre uma falante nativa de português brasileiro (professora) e um falante nativo de italiano (aluno) e verificamos que tanto a professora quanto o aluno, embora tenham utilizado táticas diversas, ambos atenuaram a discordância, o que demonstra o desejo dos interlocutores de manter o equilíbrio das relações interpessoais, prevenindo ameaçar à face positiva um do outro.

\subsubsection{Partículas discursivas, expressões de controle e de contato com o interlocutor}

Outra tática também muito utilizada na aula de Português, para atenuar os atos de discordância, foi o uso de partículas discursivas, expressões de controle e de contato com 
o interlocutor, isto é, formas que atenuam os atos de fala solicitando o consentimento do interlocutor e, assim, evitando um possível desacordo.

Vejamos o seguinte trecho da aula, em que a professora de português, havia perguntado para os alunos onde o personagem do Mister teria ido para conseguir a lista com os nomes dos donos de fusca bordô da cidade.

\section{FRAGMENTO DIS-PT n ${ }^{\circ} 9$}

$C$ : concessionária de carros

Prof PORT: concessionária de carro? o que que é uma concessionária? o que que FAZ uma concessionária?

$C$ : VENDE carro

$T$ : e conserta

Prof PORT: vende carros e conserta na verdade esse registro nós temos no departamento de trân-si-to tá? aqui no Brasil chama-se DETRAN

Notamos, nessa interação, a tentativa da professora de conduzir os alunos até o nome do local aonde o personagem do Mister teria ido, isto é, ao departamento de trânsito da cidade. Percebemos que a aluna $\mathrm{C}$ fornece uma resposta que a professora considera incorreta, porém, não discorda imediatamente da aluna. Ao contrário, repete a resposta de $\mathrm{C}$ mudando a entonação da voz, transformando a afirmação em pergunta e criando uma dúvida. Em seguida, a professora acrescenta outras informações para tentar levar os alunos à resposta correta e pergunta o que é e o que faz uma concessionária. A aluna $\mathrm{C}$ responde que uma concessionária vende carros e o aluno $\mathrm{T}$ afirma que uma concessionária também conserta carros. Na sequência, a professora repete o que os alunos disseram, concordando com eles em relação às funções de uma concessionária, mas discordando em relação à informação que ela havia solicitado sobre a narrativa, pois o personagem do Mister não foi a uma concessionária e, sim, ao departamento de trânsito da cidade.

A professora, ao manifestar sua discordância, atenua-a de diversas formas. Primeiro, escolhe realizá-la de modo indireto, transformando a resposta da aluna em pergunta, dandolhe assim a opção de refletir um pouco mais e de mudar a sua resposta. Como os alunos não conseguem chegar à resposta esperada pela professora, ela decide fornecê-la, mas o faz também de uma forma atenuada, evitando ameaçar a face positiva dos alunos que havíam participado da discussão até aquele momento. Assim, a professora faz uso de mais dois procedimentos atenuadores, um marcador discursivo modal de objetivação na verdade e uma 
partícula discursiva de controle e contato com o interlocutor: esse registro nos temos no departamento de trân-si-to tá?

A utilização do marcador discursivo modal de objetivação na verdade apaga a responsabilidade do enunciador sobre a enunciação, isto é, não é a professora que está afirmando que foi no departamento de trânsito da cidade, mas é o fato de esse registro só poder ser encontrado naquele lugar. Já a utilização das partículas discursivas e expressões de controle e contato com o interlocutor, segundo Albelda et al. (2014), buscam uma aliança durante a interação e minimizam desconformidades, atenuando possíveis desacordos e oferecendo opções ao outro.

Dessa maneira, notamos, mais uma vez, como a atenuação está presente na constituição das relações em sala de aula e como ela é importante, principalmente, em atos de fala que podem ameaçar a face dos interlocutores, como a discordância, pois através da suavização desses atos é possível manter uma relação harmoniosa e respeitosa entre os interlocutores, além de produtiva em termos de aprendizado.

O próximo fragmento já foi apresentado antes, mas o trouxemos novamente para destacar o uso da expressão de controle e de contato com o interlocutor para atenuar a discordância. Relembramos que, nesse momento, a professora manifestava surpresa pelo fato de o personagem do Mister ter cuspido o uísque.

\section{FRAGMENTO DIS-PT $n^{\circ} 2$}

Prof PORT:: NOSSA mas ele não gostava de UÍSque?

$L$ : sim mas ele bebeu muito

Prof PORT:: será?

$R a$ : não é muito

Prof PORT: estranho né?

Podemos notar, mais uma vez, que a professora atenua sua discordância de várias formas, dentre elas, expressando-a de forma indireta, por meio de duas perguntas com o objetivo de evitar hostilidade na interação: será?/ estranho né? Além disso, a professora emprega tempos verbais modalizados, como a utilização do futuro no lugar do presente, na pergunta será? (ao invés de é) e utiliza, também, uma expressão de contato e de controle com o interlocutor estranho né? que possui a função de buscar o acordo, isto é, a professora tenta se aproximar do aluno evitando um desacordo conflituoso. Dessa forma, não ocorre tensão ou embate na interação que continua fluindo de maneira harmoniosa. 
O próximo fragmento em que foi possível notar a presença de partículas discursivas e expressões de controle e de contato com o interlocutor como recurso atenuador foi o fragmento $\mathrm{n}^{\circ}$ 3. Esse fragmento, também já apresentado anteriormente, é encontrado no momento da aula em que a professora de português pergunta para os alunos se eles sabem o significado de uma palavra que apareceu no texto.

\section{FRAGMENTO DIS-PT $n^{0} 3$}

Prof PORT: QUE QUE é xaveco gente?

$C$ : XAVECO eu acho que eu sei é aquele CArinha da turma da Mônica

Prof PORT: ah é também mas se fosse seria escrito com letra maiúscula tá C? porque aí seria o NOme do personagem

Podemos observar que, quando a aluna $\mathrm{C}$ responde, a professora discorda dela, de forma atenuada, fazendo uso de alguns procedimentos, dentre os quais o movimento concessivo-opositivo, já visto anteriormente, as partículas discursivas e as expressões de controle e de contato com o interlocutor, quando solicita o acordo de C para prosseguir dizendo se fosse seria escrito com letra maiúscula tá $C$ ? A utilização desse recurso atenua um possível desacordo, porque solicita justamente o acordo do interlocutor e, assim, previne qualquer ameaça à face positiva da aluna.

Trouxemos novamente mais um fragmento já apresentado antes, para destacar que essa tática atenuadora também foi usada em outro momento da aula, quando o aluno R disse não saber a diferença entre o telefone fixo e o celular.

\section{FRAGMENTO DISC-PT $\mathbf{n}^{0} 10$}

Prof PORT: você não SABE a diferença do fixo e do celuLAR?

$R$ : não não faço a menor ideia

Prof PORT: você tem telefone fixo na sua CAsa?

$R$ : ahn::: fixo fixo não

$R a$ : $\mathrm{R}$ o fixo é o de casa

Prof PORT: não pera só um pouquinho ... o fixo você TEM um telefone que fica DENtro da sua casa? $R$ : que CArrega dentro de casa sim

Prof PORT: isso chama-se telefone fixo porque você não pode tirar ele da sua casa pra falar em outro lugar ... PORQUE R... ele é conectado a:: uma rede de transmissão e ele só vai funcionar dentro da sua casa... EXISTE um CABO que vai fazer a ligaÇÃO pra ele funcionar DENtro da sua casa

$F o$ : se tirar aquele telefone ele funciona

Prof PORT: não mas fora do raio de ação da BAse... ele não funciona tá?

$R$ : mas o meu não tem cabo

Prof PORT: ele ESTÁ conectado na base do seu telefone 
A professora, após toda a descrição e caracterização do telefone fixo, ouve do aluno Fo o seguinte comentário se tirar aquele telefone ele funciona, o aluno referia-se à seguinte frase da professora porque você não pode tirar ele da sua casa pra falar em outro lugar. O aluno discordou da professora porque pensou no telefone fixo com aparelho sem fio, que o usuário pode tirar da base, sem interromper seu funcionamento. A professora discordou do aluno fazendo referência ao fato de que o usuário não pode usar o telefone fixo sem fio da mesma forma que usa o celular, pois fora de casa o telefone sem fio não funciona, não tem alcance, por isso a professora diz não mas fora do raio de ação da BAse... ele não funciona tá? Assim, a partícula discursiva "tá" usada no fim da frase atenua a discordância, porque exerce a função de evitar um novo desacordo. É como se a professora quisesse a confirmação do aluno de que ele havia entendido. Dessa forma, vemos sua preocupação em discordar sem colocar em risco a face positiva do aluno, preservando assim a boa relação com ele em sala de aula.

No fragmento $\mathrm{n}^{\circ} 8$, notamos, também, a presença da partícula "tá" usada pela professora como forma de atenuar o ato de discordância.

\section{FRAGMENTO DIS-PT $n^{\circ} 8$}

Prof PORT: I::sso você já viu uma lista telefônica?

((alguns alunos respondem que sim e outros que já))

Prof PORT:o que que ela CONTÉM?

Fo: ela tem o número de telefone As ru::as... número de telefone das pessoas

Prof PORT: das pessoas exato i::sso então ela é um catálogo um livro que tem o NOme do dono da

LInha telefônica endereço e o número de telefone ... ele procurou lá não achou QUE outro lugar ele procurou?

Fo: no mapa da cidade

Prof PORT: no GUIA da cidade alguém aqui já viu o guia da cidade de São Paulo?

Fo: $\operatorname{sim}$

Prof PORT: o guia de RUAS?

((Classe fica em silêncio))

Prof PORT:: Não?

Fo: eu sim eu já

Prof PORT: comé/ que ele é?

Fo: ele é tipo uma coisa assim ((abre os braços e faz um quadrado no ar))

$B$ : é tipo um quaDRADO tem todas as ruas os nomes

Prof PORT: não... o guia de ruas é um LIvro você pode ter visto um MApa tá?

((B balança a cabeça afirmativamente $))$

Aqui também observa-se que a professora não concorda com o aluno B quando ele afirma que o guia de ruas é um quadrado, mas ela expressa discordância de maneira atenuada, dentre os recursos atenuadores empregados por ela, destacamos aqui a utilização da partícula 
discursiva de contato "tá" que, mais uma vez, solicita o consentimento do interlocutor prevenindo conflitos na interação e na relação professor-aluno.

Juntamente com a concessividade, a utilização da partícula discursiva de contato foram as táticas mais utilizadas nos atos de discordância realizados em português, em sala de aula. Nas aulas de Italiano, esse recurso foi utilizado apenas uma vez, nos atos de discordância. Na sequência, apresentaremos o trecho em que esse recurso apareceu.

O próximo fragmento, extraído da aula de italiano, mostra o momento em que os alunos deveriam discutir sobre a frase: Le bambine e i bambini hanno diritto all'affetto, ou seja, meninos e meninas têm direito a (receber) afeto. Algumas crianças diziam que esse direito correspondia ao fato de receber carinho dos pais. Diante disso, a professora perguntou o que aconteceria se os pais morressem, isto é, na ausência deles, quem deveria dar amor às crianças. Então, o aluno $\mathrm{S}$ disse que, nesse caso, os responsáveis seriam os amigos, já os alunos L e Ra disseram que seriam o avô, a tia, os familiares. Então, a professora perguntou se, por acaso, a escola também não seria um lugar no qual é possível sentir o carinho das outras pessoas. $\mathrm{O}$ aluno $\mathrm{S}$, imediatamente, discordou da professora dizendo: si pensa [até parece] e, ela também discordou da opinião do aluno, como pode ser observado abaixo.

\section{FRAGMENTO DIS-IT $\mathbf{n}^{\circ} 3$}

\section{Italiano}

Prof IT: e SE la persona:: se i genitori sono già morti? neSSUno? deve dare affetto a questa persona?

Ma: MAESTRA ((alza la mano))

Prof IT: ASPETTA

$S:$ amico

Prof IT: CHI? l'amico? L che ne dici?

$L$ : il nonno... la zia

$R a$ : i familiari

Prof IT: LA SCUOLA non è anche un posto dove un bambino può ... sentire l'affetto delle persone? $S$ : si PENsa

Prof IT: AI:: $\mathrm{S}$ tu sei triste oggi vuoi più attenzione vero? ti coNOSco

\section{Tradução}

Prof IT: e SE a pessoa:: se os pais já morreram? NinGUÉm? deve dar carinho para essa pessoa?

$M a$ : PROFESSORA ((levanta a mão))

Prof IT: ESPERA

$S:$ amigo

Prof IT: QUEM? o amigo? L o que você acha?

$L:$ o avô... a tia

$R a$ : os familiares

Prof IT: A ESCOLA não é também um lugar onde uma criança pode ... sentir o carinho das pessoas?

$S$ : até PArece

Prof IT: AI:: $\mathrm{S}$ você está triste hoje quer mais atenção né? te coNHEço

Verificamos que já na pergunta da professora é possível encontrar um procedimento atenuador, quando ela diz: LA SCUOLA non è anche un posto dove un bambino può ... sentire l'affetto delle persone? A professora elabora a pergunta de forma atenuada, impersonalizando sua enunciação para se auto proteger, isto é, para criar um distanciamento em relação ao 
enunciado, reduzindo, assim, seu compromisso com ele, porque pode afetar a sua própria imagem. Em outras palavras, a professora utiliza o nome da instituição que representa, ou seja, a escola para evitar a responsabilidade sobre aquilo que é dito. Desse modo, a escola seria responsável por oferecer afeto às crianças e não ela diretamente.

Porém, o aluno S discorda do fato de que a escola seria um lugar para dar e receber afeto e exterioriza sua discordância de forma direta, sem a utilização de atenuadores, com a seguinte frase: si pensa. Ao ouvir isso, a professora, discorda indiretamente emitindo um julgamento sobre o estado de espírito do aluno naquele dia AI:: S tu sei triste oggi vuoi più attenzione vero? ti coNOSco [AI:: S você está triste hoje quer mais atenção né? te coNHEço].

A professora afirma que o aluno só havia discordado, porque se sentia triste naquele dia e, portanto, não estava sentindo o carinho das outras pessoas, porque queria mais atenção. A professora, após a constatação que o aluno se sente triste, faz uso de uma expressão de contato "vero?", solicitando a S sua confirmação. Dessa forma, a discordância é atenuada por meio da indiretividade e por meio da utilização de uma expressão de contato com o interlocutor e tais procedimentos evitam uma ameaça à face positiva do aluno e mantêm o equílibrio da interação.

\subsubsection{Modalização dos tempos verbais}

Outro procedimento também muito utilizado para atenuar os atos de discordância em língua portuguesa foi a modalização dos tempos verbais. A ação era suavizada por meio do emprego do modo condicional (futuro do pretérito) no lugar do presente ou do imperativo, ou utilizando o imperfeito, onde poderia também ter sido usado um presente ou um imperativo ou, ainda, usando o futuro no lugar do presente (com valor epistêmico - futuro de probabilidade). Esse procedimento foi utilizado apenas nas discordâncias realizadas em língua portuguesa, não sendo encontrado nos atos de discordância em língua italiana.

O primeiro exemplo refere-se ao momento da aula de português em que ocorria uma discussão sobre um trecho do livro $O$ Gênio do Crime.

\section{FRAGMENTO DIS-PT n ${ }^{0} 1$}

Prof PORT: então gente o::: a gente tá vendo tudo isso que tá acontecendo aqui ... tá acontecendo lá na FÁbrica o gordo sendo tortuRAdo pressioNAdo então aqui o que que ele vai fazer ele vai nos explicar 
como é:: que as pessoas que conviviam com o gordo e tavam envolvidas na investigação estavam Agindo... essa é a notícia de que o gordo SUMIU então como é que o Mister tá usando seus métodos para descobrir aonde ele foi quem levou, né? ele tem uma pista muito simples que é o carro e um nome, que era um nome falso, onde será que ele foi que ele conseguiu a lista de donos de fusca bordô? onde cês acham que é esse lugar? ONDE PODERIA ser na verdade?

$C$ : naquele lugar

Fo: maquininha de fotocópia...

Prof PORT: então mas AOnde? ele foi ao DEPARTAMENTO da cidade... que que seria esse departamento da cidade? QUAL departamento seria esse?

Fo: na polícia

$T$ : na delegacia

Prof PORT: na delegaCla? será que na delegacia tem uma relação de CARROS e o nome do dono do carro a cor e TUDO mais?

L e Ra: $\operatorname{sim}$

Notamos que a professora atenua sua enunciação fazendo uso modalizado dos tempos verbais, tanto nas perguntas quanto na discordância expressa de modo indireto. Assim, ela emprega o tempo verbal no condicional no lugar do presente do indicativo, na pergunta: ONDE PODERIA ser na verdade? ao invés de dizer "onde é na verdade?" quando faz referência ao lugar em que o personagem do Mister foi para conseguir a lista com o nome dos donos de fusca bordô. Na sequência, a professora pergunta para os alunos o que que seria esse departamento da cidade? QUAL departamento seria esse? no lugar de perguntar "que departamento é esse" ?

O aluno T responde que o lugar é a delegacia, então a professora discorda dele, de modo indireto, mudando o tom de voz e repetindo a resposta dele em forma de pergunta: será que na delegacia tem uma relação de carros e o nome do dono do carro a cor e tudo mais? Percebemos que a professora discorda do aluno, mas opta por não dizer de modo direto que a resposta está errada. No lugar de fazer isso, atenua sua discordância lançando uma pergunta que é formulada com o tempo verbal no futuro no lugar do presente para expressar probabilidade. Albelda et al. (2014) afirmam que o uso modalizado dos tempos verbais, de acordo com cada contexto, desfocaliza o eixo temporal com a finalidade de expressar a ação de forma mais suave. "É o que alguns autores chamaram de "deslocados" dos tempos do verbo, que desfocalizam o eixo temporal com o objetivo, de acordo com cada contexto, de expressar a ação de forma mais suave" [Son los que algunos autores han llamado usos 'dislocados' de los tiempos verbales, los cuales desfocalizan el eje temporal con la finalidad, de acuerdo con cada contexto, de expresar la acción de forma más suave.] (p.15). Com essas estratégias, a professora evita ameaçar a face positiva do aluno e, ao mesmo tempo, estimula sua reflexão sobre o tema. 
Observamos a modalização dos tempos verbais como forma de atenuar uma discordância também no próximo fragmento, em que, ainda, falando sobre o livro, a professora explorava a compreensão dos fatos da narrativa.

\section{FRAGMENTO DIS-PT n ${ }^{\circ} 11$}

Prof PORT: não eles vão procurar imiTAdo::res né? de pessoas de voz ou... imitadores de passarinho... são pessoas que tem facilidade de ouvir o som memoriZAR o TIpo a FORma e:: reproduzir tá? e:: ao mesmo tempo ele dividiu a lista telefônica em cinco partes e deu uma pra cada um PRA que será que ele deu... pras pessoas... pros meninos isso?

$L$ : pra Pituca pro Edmundo pra::... Berenice Prof PORT: pra QUÊ?

Fo: pra anotar

Prof PORT: pra anotar?

Fo: as coisas que eles queriam

$L$ : os lugares que ele já foi... e os que não

Prof PORT: poderíam também estar procurando RUas que terminassem com este final de palavra?

$L:$ sim... que terminavam com eta

Nesse fragmento, verificamos que a professora de português modaliza o tempo verbal do presente do indicativo para o condicional, para expressar uma discordância de forma atenuada. A professora havia feito a seguinte pergunta: e:: ao mesmo tempo ele dividiu a lista telefônica em cinco partes e deu uma pra cada um PRA que será que ele deu... pras pessoas... pros meninos isso? Como nenhum dos alunos chegou à resposta desejada, então, a professora sugeriu a resposta, em forma de pergunta, o que revela que ela discordava das respostas que haviam sido fornecidas anteriormente pelos alunos. Assim, a professora disse poderíam também estar procurando RUas que terminassem com este final de palavra? $\mathrm{O}$ uso da atenuação, como vimos, previne conflitos interacionais e, nesse contexto, favorece a construção de um ambiente propício para o aprendizado, no qual o aluno aprende não somente a (re)construir o sentido de um texto, mas também as normas sociais que moldam e regem a interação.

A seguir, mais um fragmento em que verificamos a presença de tempos verbais modalizados, como forma de atenuar a força ilocucionária do ato de discordância.

\section{FRAGMENTO DIS-PT $n^{\circ} 2$}

Prof PORT:: NOSSA mas ele não gostava de UÍSque?

$L$ : sim mas ele bebeu muito

Prof PORT:: será?

$R a$ : não é muito 
Prof PORT: estranho né?

A professora demonstra sua discordância de forma duplamente atenuada, pois a manifesta de forma indireta por meio de uma pergunta e modaliza o verbo, preferindo o futuro no lugar do presente, na pergunta será? (ao invés de é). Com mais esse procedimento confirma-se a preocupação da professora em prevenir possíveis danos à face positiva dos alunos e também em preservar a relação harmoniosa em sala de aula.

No próximo fragmento retomamos o momento da aula em que apareceu a palavra xaveco.

\section{FRAGMENTO DIS-PT n 3}

Prof PORT: QUE QUE é xaveco gente?

$C$ : XAVECO eu acho que eu sei é aquele CArinha da turma da Mônica

Prof PORT: ah é também mas se fosse seria escrito com letra maiúscula tá $\mathrm{C}$ ? porque aí seria o NOme do personagem

Nesse trecho, também notamos que a discordância expressa pela professora é realizada de maneira atenuada, porém, dessa vez, ela não utilizou o recurso indireto da pergunta, mas escolheu outras táticas atenuadoras para suavizar a força ilocucionária do seu ato, como o movimento concessivo-opositivo, analisado anteriormente e a utilização do tempo verbal no condicional ao invés do presente: seria escrito com letra maiúscula, tá C? porque aí seria o nome do personagem. A professora utilizou, ainda, outras táticas para enfraquecer o ato de discordância como chamar a aluna $\mathrm{C}$ pelo nome e utilizar a partícula descritiva de contato com o interlocutor, quando solicitou o consentimento de $\mathrm{C}$ para prosseguir, atenuando um possível desacordo entre ela e a aluna se fosse seria escrito com letra maiúscula tá C?

O próximo fragmento, também já apresentado anteriormente, refere-se ao momento da aula em que o aluno R não concorda com a opinião da professora de que seria o detetive que descobriria o cativeiro de Bolacha e diz mas não vai ser ele e a professora responde será que não?

\section{FRAGMENTO DIS-PT $\mathbf{n}^{\circ} 5$}

Prof PORT: o detetive o invicto né? se alguém vai descobrir alguma coisa aí vai ser ele né gente? Não tem essa fama à toa

$R$ : mas não vai ser ele

Prof PORT: será que não?

$R$ : não eu tenho certeza 
Prof PORT: você tem certeza? (com tom doce).

(( a professora coloca os óculos e olha para o livro))

Prof PORT: vamos lá então gente página 103 a gente vai fazer uma ordem vamos seguindo assim

Retomando o fragmento acima, o aluno $\mathrm{R}$ não concorda com a afirmação da professora e diz mas não vai ser ele. A atenuação da discordância está presente no movimento concessivo-opositivo, como vimos anteriormente. A professora, por sua vez, também discorda da afirmação do aluno e demonstra isso indiretamente, por meio da pergunta será que não? $\mathrm{Na}$ formulação da pergunta, a professora recorre à modalização do tempo verbal do presente para o futuro de probabilidade que, como vimos, reduz a ocorrência de conflitos na interação e na relação entre professora e aluno.

Notamos que, embora, a professora seja a autoridade em sala de aula e, portanto, goze de maior poder sobre os alunos, ela demonstra uma constante preocupação e um contínuo cuidado em formular atos de discordância atenuados. Além disso, na maioria das vezes, a atenuação é usada como forma de prevenir uma ameaça à face positiva dos alunos, o que evidencia a construção de um contexto de sala de aula em que domina a cortesia favorecendo, assim, as trocas verbais, as relações pessoais e o processo de ensino e de aprendizagem.

Como afirmado anteriormente, na aula de Italiano não encontramos a modalização dos tempos verbais como tática atenuadora nos atos de discordância.

\subsubsection{Elementos prosódicos; formas de tratamento, formas apelativas convencionalizadas $e$ marcadores discursivos modais de objetivação}

Outros recursos atenuadores presentes nos atos de discordância produzidos em língua portuguesa foram: o emprego de elementos prosódicos (XXI); formas de tratamento, formas apelativas convencionalizadas (XX) e marcadores discursivos modais de objetivação (XVIII).

Com relação à atenuação por meio de elementos prosódicos, isto é, da mudança de entonação ao pronunciar as palavras com o objetivo de suavizar a discordância, esse procedimento foi encontrado somente nas discordâncias realizadas em língua portuguesa. Os exemplos do português são os seguintes: 


\section{FRAGMENTO DIS-PT $\mathbf{n}^{\circ} 1$}

Prof PORT: então gente o::: a gente tá vendo tudo isso que tá acontecendo aqui ... tá acontecendo lá na FÁbrica o gordo sendo tortuRAdo pressioNAdo então aqui o que que ele vai fazer ele vai nos explicar como é:: que as pessoas que conviviam com o gordo e tavam envolvidas na investigação estavam Agindo... essa é a notícia de que o gordo SUMIU então como é que o Mister tá usando seus métodos para descobrir aonde ele foi quem levou, né? ele tem uma pista muito simples que é o carro e um nome, que era um nome falso, onde será que ele foi que ele conseguiu a lista de donos de fusca bordô? onde cês acham que é esse lugar? ONDE PODERIA ser na verdade?

$C$ : naquele lugar

Fo: maquininha de fotocópia...

Prof PORT: então mas AOnde? ele foi ao DEPARTAMENTO da cidade... que que seria esse departamento da cidade? QUAL departamento seria esse?

Fo: na polícia

$T$ : na delegacia

Prof PORT: na delegacia? será que na delegacia tem uma relação de carros e o nome do dono do carro a cor e tudo mais?

Le Ra: sim

$C$ : é::...não... na concessionária

Prof PORT: não entendi

$C$ : concessionária de carros

Prof PORT: concessionária de carro? o que que é uma concessionária? o que que FAZ uma concessionária?

$C$ : VENDE carro

$T$ : e conserta

Prof PORT: vende carros e conserta na verdade esse registro nos temos no departamento de trân-si-to tá? aqui no Brasil chama-se DETRAN

Nesse fragmento, as partes em negrito indicam as discordâncias da professora, realizadas através da mudança da entonação de voz, a partir das respostas dos alunos. Repetindo as respostas dos alunos, em forma de interrogação, a professora coloca em dúvida o conteúdo da afirmação e os induz a pensar em outra possibilidade de resposta. Observa-se que a professora faz uma série de perguntas que demonstram que as respostas que estavam sendo fornecidas pelos alunos não estavam corretas, segundo o julgamento da professora. Ao escolher minimizar a força ilocucionária da discordância e, consequentemente da correção em sala de aula, a professora previne a ameaça à face positiva dos alunos e preserva a harmonia das relações interpessoais em sala de aula. Com essa estratégia a professora evita também que os alunos fiquem receosos em participar da aula por medo de fornecerem respostas incorretas e com isso se sintam constrangidos diante dos demais alunos da classe.

Além disso, formulando perguntas a partir das respostas que os alunos fornecem, a professora não as julga diretamente, embora não esteja de acordo com elas, mas conduz às respostas, estimulando o raciocínio e a reflexão nos alunos. 
O mesmo acontece nos seguintes fragmentos:

\section{FRAGMENTO DIS-PT n ${ }^{\circ} 11$}

Prof PORT: não eles vão procurar imiTAdo::res né? de pessoas de voz ou... imitadores de passarinho... são pessoas que tem facilidade de ouvir o som memoriZAR o TIpo a FORma e:: reproduzir tá? e:: ao mesmo tempo ele dividiu a lista telefônica em cinco partes e deu uma pra cada um PRA que será que ele deu... pras pessoas... pros meninos isso?

$L$ : pra Pituca pro Edmundo pra::... Berenice

Prof PORT: pra QUÊ?

Fo: pra anotar

Prof PORT: pra anotar?

$F o$ : as coisas que eles queriam

$L$ : os lugares que ele já foi... e os que não

Prof PORT: poderíam também estar procurando RUas que terminassem com este final de palavra?

$L: \operatorname{sim} . .$. que terminavam com eta

Observamos aqui como a professora discorda do aluno Fo mudando a entonação da resposta dele e transformando-a em pergunta.

\section{FRAGMENTO DIS-PT $\mathbf{n}^{\circ} 12$}

$R$ : se não tinha celular como é que então tinha aquela fábrica de tecidos?

Prof PORT: gente alguém tem essa resposta? se não tinha celular como é que tinha fábrica de tecidos eu pergunto AHN::.... antes do celular as pessoas não se vestiAM?

((as crianças dão risada))

$R$ : não sei

Prof PORT: quando você ACHA que surgiu o celular? há quanto tempo?

T: 10 anos

$L: 100$ anos

Prof PORT: O CELULAR?

$B$ : NÃO...uns 40 anos eu acho

Prof PORT: nossa (( a professora olha para mim e dá risada))

((as crianças começam a falar todas ao mesmo tempo tentando acertar a data de criação do celular.

Ra levanta a mão))

Prof PORT: fala

Ra: 20 anos?

Prof PORT: isso gente o celular é uma invenção MUITO recente

No fragmento acima, como já vimos, o aluno R confunde o surgimento do telefone com o surgimento do celular e pergunta como seria possível existir uma fábrica e não existir telefone. Nesse momento, a professora faz a pergunta de $\mathrm{R}$ para a classe, usa a forma de tratamento gente para aproximar-se dos alunos e a seguir reformula a pergunta de $\mathrm{R}$ de uma forma irônica e engraçada: antes do celular as pessoas não se vestiAM ? As crianças dão 
risada. $\mathrm{O}$ aluno $\mathrm{R}$ diz não saber a resposta e então a professora lhe pergunta quando ele achava que o celular tinha surgido.

Os alunos arriscam algumas datas, como 10 e 100 anos. A professora surpreende-se e diz $\boldsymbol{O}$ CELULAR? Na pergunta da professora está presente, de forma implícita, sua discordância em relação aos palpites das crianças, percebemos isso através da entonação de voz e por meio da expressão facial da professora. Na sequência, o aluno B opina de forma atenuada, usando um verbo que limita sua opinião: uns 40 anos eu acho. Com isso, enfatiza que é a opinião dele, mas que não tem certeza, tal procedimento atenuador é uma maneira de proteger sua imagem, como já vimos anteriormente. A professora espanta-se com a resposta do aluno, parece não acreditar que falta aquele conhecimento para as crianças. Enfim, a aluna $\mathrm{Ra}$ acerta a data de surgimento do celular e a professora confirma a resposta para a classe, por meio de um vocativo em que usa gente, como se a classe inteira tivesse acertado, ela diz: isso gente o celular é uma invenção muito recente. Dessa forma, atenua e aproxima-se mais uma vez dos alunos, fortalecendo sua relação cordial com eles.

Na sequência, a professora explica que as fábricas de tecido são uma invenção do século XVIII-XIX, afirma que primeiro surgiram as fábricas e que o celular só pôde surgir, recentemente, há pouco mais de 15 anos, por conta da revolução da tecnologia e que, portanto, as pessoas se vestiam antes do surgimento do celular.

Ainda sobre a discussão da narrativa do livro, percebemos, mais uma vez, que a professora usa a prosódia para suavizar a força ilocucionária do seu ato de discordar, como pode ser obervado no exemplo abaixo.

\section{FRAGMENTO DIS-PT no 5}

Prof PORT: o detetive:: o invicto né? se alguém vai descobrir alguma coisa aí... vai ser ele né gente? [Não tem essa fama à toa

$R$ : mas não vai ser ele

Prof PORT: será que não?

$R$ : não eu tenho certeza

Prof PORT: você tem certeza? ((com tom doce))

(( a professora coloca os óculos e olha para o livro ))

Prof PORT: vamos lá então gente página 103 a gente vai fazer uma ordem vamos seguindo assim

Logo após a discordância expressa pelo aluno em relação ao fato de não ser o personagem do Mister que iria descobrir onde o personagem do Bolacha estava mas não vai ser ele, a professora faz a seguinte pergunta será que não? Como o aluno insiste na resposta 
dizendo não eu tenho certeza, a professora, sabendo que a resposta do aluno não era correta, exprime a sua discordância fazendo outra pergunta com tom de voz doce você tem certeza? Observamos assim, um sequência de opiniões opostas expressas por discordâncias atenuadas, tal atenuação evidencia cortesia verbal, pois entram em jogo o respeito e a consideração. Segundo Goffman (2011 [1967]), como cada ser humano reivindica para si uma imagem social positiva, a fim de construí-la durante a interação com os demais, tentará equilibrar respeito por si próprio e consideração pelos outros.

o efeito combinado da regra do respeito próprio e da regra da consideração é que a pessoa tende a se conduzir durante um encontro de forma a manter tanto a sua própria imagem quanto as imagens dos outros participantes. Isto significa que normalmente permitimos que a linha assumida por cada participante prevaleça, e que cada participante desempenhe o papel que ele pareça ter escolhido para si próprio. Estabelecemos um estado em que todos temporariamente aceitam a linha de todos os outros. Esse tipo de aceitação mútua parece ser uma característica estrutural básica da interação, especialmente da interação em conversas face a face. ( p.21)

Desse modo, professora e aluno escolheram manifestar discordância de forma atenuada, usando o recurso da indiretividade e da prosódia (no caso da professora) e assim conservando o equilíbrio das relações interpessoais em sala de aula. Nas aulas de Italiano esse recurso não foi utilizado nos atos de discordância.

Outro recurso com função atenuadora, mencionado acima, encontrado nos atos de discordância realizados durante a aula de língua portuguesa e de língua italiana foi a utilização de formas de tratamento e formas apelativas convencionalizadas.

Nesse fragmento, já apresentado anteriormente, podemos observar que a professora utiliza uma forma de tratamento, chamando a aluna pelo nome próprio, como tática para atenuar a força da discordância.

\section{FRAGMENTO DIS-PT $n^{0} 3$}

Prof PORT: QUE QUE é xaveco gente?

$C$ : XAVECO eu acho que eu sei é aquele CArinha da turma da Mônica

Prof PORT: ah é também mas se fosse seria escrito com letra maiúscula tá $\mathbf{C}$ ? porque aí seria o NOme do personagem

Como já dito anteriormente, nesse ato de discordância estão presentes vários recursos, como a concessividade, a modalização dos tempos verbais e a utilização de um apelativo. Ao 
chamar a aluna pelo nome próprio (C), utilizado juntamente com a partícula descritiva de contato com o interlocutor ah é também mas se fosse seria escrito com letra maiúscula tá $\boldsymbol{C}$ ? deixa o ato de discordar mais brando e menos ameaçador.

No próximo fragmento nota-se que a professora, além dos recursos atenuadores já observados anteriormente como a concessividade, também escolhe chamar o aluno pelo nome, criando um contato direto com ele e buscando empatia.

\section{FRAGMENTO DIS-PT $\mathbf{n}^{0} 7$}

Fo: se tirar aquele telefone ele funciona

Prof PORT: não mas fora do raio de ação da BAse... ele não funciona tá?

$R$ : mas o meu não tem cabo

Prof PORT: ele ESTÁ conectado na base do seu telefone

$R$ : então mas ele não tem CAbo o meu fixo

Prof PORT: tem que ter $\mathbf{R}$

$R:$ não TEM CABO

Fo: ah:: é aquele lá

Prof PORT: R ele ESTÁ conectado à base do seu telefone... você chega em casa hoje e vai olhar

$R:$ sim não tem cabo posso ir até meu quarto

Fo: é esse aqui:: ((faz um gesto com a mão indicando o tamanho do aparelho, mas $R$ não pode ver porque Fo está sentado atrás dele))

Prof PORT: você leva uma PARTE dele $\mathbf{R}$

$R$ : não entendi ainda

Prof PORT: você CARREGA na sua casa uma PARTE DELE a outra parte você tem que por pra carregar numa base... não tem?

$R: \operatorname{sim}$

Quando o aluno R, referindo-se ao tipo de aparelho telefônico que tem em casa, diz então mas ele não tem CAbo o meu fixo, a professora discorda e insiste com o aluno dizendo tem que ter $\boldsymbol{R}$. Mais adiante, a professora insiste novamente afirmando você leva uma PARTE dele R. Nesses dois atos de discordância realizados pela professora, ela chama o aluno pelo nome para criar um grau de aproximação maior com ele e, juntamente, muda a entonação o que suaviza a força da discordância. O objetivo é fazer com que o aluno entenda a diferença do telefone fixo e do celular sem precisar entrar em conflito direto com o aluno, preservando assim, a harmonia das trocas verbais e da relação entre os dois.

O emprego de formas de tratamento e de formas apelativas convencionalizadas, tem por finalidade segundo Albelda et al. (2014), aproximar o falante do interlocutor, criando um acordo ou um consenso entre eles e por vezes minimizando a enunciação quando pode ser ameaçadora. Nas palavras dos autores: 
(...) fórmulas de tratamento e as fórmulas apelativas convencionalizadas (...) todas elas evidenciam uma proximidade do falante com o interlocutor para minimizar o que é dito se houver um potencial de ameaça ou para lidar com situações de negatividade. Com elas, se busca chegar a um acordo ou minimizar o desacordo.

[(...)las fórmulas de tratamiento y las fórmulas apelativas convencionalizadas (...) todas ellas muestran acercamiento al otro para minimizar lo dicho si existe un potencial de amenaza, o para atender situaciones de negatividad. Con elas, se busca lograr el acuerdo o minimizar el desacuerdo.] ( p.24)

Nas aulas de italiano, as formas de tratamento e as formas apelativas convencionalizadas também foram utilizadas para suavizar a força ilocucionária da discordância.

O próximo fragmento destaca a interação ocorrida durante a leitura de um dos textos na aula de italiano. A professora perguntou para os alunos de quem era a vez de ler. Neste momento, os alunos L e B levantam a mão e dizem que ainda não leram.

\section{FRAGMENTO DIS-IT no 4}

Italiano

Prof IT: l'ultimo diRItto... è vai:: F... chi deve leggere? F e A vero?

$L$ : anche io non ho [ancora

$B$ : anche io non ho ancora

Prof IT: MA STIAMO seguendo quall'ordine amore? VAI L e F

\section{Tradução}

Prof IT: o último diREIto... é vai:: F... quem deve ler? F e A né?

$L$ : eu também [ainda não

$B$ : eu também ainda não

Prof IT: MAS ESTAMOS seguindo qual ordem amor? VAI L e F

Quando olhamos para o contexto, percebemos que a pergunta da professora não é uma indagação motivada por uma dúvida, mas uma pergunta que pretende lembrar aos alunos que existia uma ordem de leitura que estava sendo seguida, estipulada no começo da atividade. Assim, quando os alunos L e B afirmam que ainda não leram, a professora discorda da reivindicação e lembra a eles que existia uma ordem de leitura MA STIAMO seguendo quall'ordine amore? A professora expressa sua discordância de maneira atenuada quando o faz de maneira indireta, por meio de pergunta e, quando utiliza, além disso, uma forma de tratamento afetuosa amore. $\mathrm{O}$ uso desses procedimentos atenuadores visa a não ameaçar a face positiva dos alunos, que poderiam se sentir desprestigiados por terem seus direitos de leitura e de participação em aula negados. Ao invés de fazer isso, a professora atenta para o fato que existia uma ordem e que para ser justa, ela deve respeitá-la. 
No próximo fragmento, já apresentado anteriormente, a professora de italiano havia perguntado para os alunos, quem no mundo seria responsável por oferecer amor e carinho às crianças. No trecho apresentado, ela pergunta se a escola também não poderia exercer essa função, nesse instante o aluno S discorda dizendo si PENsa.

\section{FRAGMENTO DIS-IT n $^{\circ} 3$}

\section{Italiano}

Prof IT: e SE la persona:: se i genitori sono già morti? neSSUno? deve dare affetto a questa persona?

Ma: MAESTRA ((alza la mano))

Prof IT: ASPETTA

$S$ : amico

Prof IT: CHI? l'amico? L che ne dici?

$L$ : il nonno... la zia

$R a$ : i familiari

Prof IT: LA SCUOLA non è anche un posto dove un bambino può ... sentire l'affetto delle persone? $S$ : si PENsa

Prof IT: AI:: $\mathbf{S}$ tu sei triste oggi vuoi più attenzione vero? ti coNOSco

\section{Tradução}

Prof IT: e SE a pessoa:: se os pais já morreram?

NinGUÉm? deve dar carinho para essa pessoa?

$M a$ : PROFESSORA ((levanta a mão))

Prof IT: ESPERA

$S$ : amigo

Prof IT: QUEM? o amigo? L o que você acha?

$L$ : o avô... a tia

$R a$ : os familiares

Prof IT: A ESCOLA não é também um lugar onde uma criança pode ... sentir o carinho das pessoas?

$S$ : até PArece

Prof IT: AI:: $\mathbf{S}$ você está triste hoje quer mais atenção né? te coNHEço

Percebemos que o aluno S não concorda com a sugestão da professora de que a escola seria um lugar no qual é possível sentir o carinho das outras pessoas e diz de modo direto e sem atenuação si PENsa. A professora, ao ouvir o aluno, discorda da afirmação dele dizendo AI:: $S$ tu sei triste oggi vuoi più attenzione vero? ti coNOSco, apesar de fazer um julgamento negativo à respeito do estado de espírito do aluno naquele dia, a professora ameniza a força do ato da discordância através de duas táticas: utilizando o nome do aluno (S) para estabelecer uma relação de aproximação com ele e empregando uma expressão de contato que solicita a concordância de S "vero"?. Todos esses procedimentos colaboram para amenizar a força ilocucionária de um ato que poderia colocar em risco a face positiva do aluno, como a discordância, buscando manter a harmonia e o equilíbrio das relações verbais em sala de aula.

Outra tática atenuadora identificada apenas nos atos de discordância produzidos em língua portuguesa foi a utilização de marcadores discursivos modais de objetivação.

No fragmento $\mathrm{n}^{\mathrm{o}} 9$ retomado abaixo, podemos notar que a professora utiliza o marcador discursivo modal de objetivação na verdade para atenuar a discordância em relação ao que os alunos haviam dito anteriormente. 


\section{FRAGMENTO DIS-PT n 9}

$C$ : concessionária de carros

Prof PORT: concessionária de carro? o que que é uma concessionária? o que que FAZ uma concessionária?

$C$ : VENDE carro

$T$ : e conserta

Prof PORT: vende carros e conserta na verdade esse registro nos temos no departamento de trân-si-to tá? aqui no Brasil chama-se DETRAN

Albelda et al. (2014) afirmam que as partículas discursivas

são partículas que afetam a franqueza do dito e fazem o interlocutor ver que o que foi expresso é compartilhado pelos demais. Em alguns casos, pode-se recorrer a formas de significado evidencial. A evidência, o lógico, pode ser o escudo para afirmar algo e evitar comprometer-se com o que se afirma.

[Son partículas que inciden en la franqueza de lo dicho y lo objetivan haciendo ver que lo expresado es compartido por los demás. En algunos casos, puede recurrirse a formas de significado evidencial. La evidencia, lo lógico, puede ser el escudo para afirmar algo y evitar, por ello, el comprometerse con lo que se afirma.] (p. 23).

Dessa forma, a utilização desse marcador causa um efeito atenuador auto-protetor, isto é, a professora transfere a responsabilidade da enunciação para a verdade dos fatos no mundo real. Em outras palavras, é como se dissesse "não sou eu que estou dizendo, mas esse registro só pode ser encontrado no departamento de trânsito da cidade, não é possível encontrá-lo em outro lugar". Dessa forma, evita a responsabilidade pelo conteúdo da informação, ao mesmo tempo que evita colocar a sua fase positiva em risco.

Já no próximo fragmento que será apresentado, é a aluna Ra que, ao discordar do seu colega de classe, em relação à ordem dos fatos da narrativa, emprega um marcador discursivo modal de objetivação, atenuando sua discordância.

\section{FRAGMENTO DIS-PT n ${ }^{\circ} 13$}

Fo: aí eles pegaram o alicate

$L:$ aí eles pegaram o alicate de ponta fina

$R a$ : na realidade o alicate foi primeiro

Prof PORT: ISSO:: o alicate foi primeiro

Mais uma vez, é possível perceber que a utilização do marcador discursivo na realidade exerce a função de auto proteção, pois a aluna $\mathrm{Ra}$ ao discordar do seu colega, evita colocar sua face positiva em risco, dando um caráter mais impessoal ao seu ato de discordar. 
Ambas as utilizações de marcadores discursivos modais de objetivação evidenciam que a discordância da professora e da aluna realizaram-se de forma atenuada, mas não cortês, uma vez que o objetivo foi o de proteger o próprio falante e não o de proteger a relação com o interlocutor.

\subsubsection{Construções que limitam ou restringem e partículas e construções justificadoras do dizer}

Dando continuidade à análise dos dados, reparamos que os seguintes recursos, com função atenuadora, foram encontrados uma única vez no corpus de língua portuguesa: construções que limitam/restringem a opinião da própria pessoa ou de um determinado âmbito (VIII) e partículas e construções justificadoras do dizer (XII).

Sobre a utilização de construções que limitam/restringem a opinião da própria pessoa ou de um determinado âmbito, encontramos apenas 1 fragmento no corpus de língua portuguesa e nenhum no corpus de língua italiana.

O fragmento encontrado é o seguinte:

\section{FRAGMENTO DIS-PT $n^{\circ} 12$}

$R$ : se não tinha celular como é que então tinha aquela fábrica de tecidos?

Prof PORT: gente alguém tem essa resposta? se não tinha celular como é que tinha fábrica de tecidos eu pergunto AHN::... antes do celular as pessoas não se vestiAM?

((as crianças dão risada $)$ )

$R$ : não sei

Prof PORT: quando você ACHA que surgiu o celular? há quanto tempo?

$T: 10$ anos

$L: 100$ anos

Prof PORT: O CELULAR?

$B$ : NÃO...uns 40 anos eu acho

Prof PORT: nossa ((a professora olha para mim e dá risada))

(( as crianças começam a falar todas ao mesmo tempo tentando acertar a data de criação do celular.

Ra levanta a mão))

Prof PORT: fala

$R a: 20$ anos?

Prof PORT: isso gente o celular é uma invenção MUITO recente

No fragmento apresentado, podemos perceber que, quando a professora pergunta a data de surgimento do celular e o aluno L responde que o celular foi inventado há 100 anos, a professora se assusta, discorda e pergunta novamente O CELULAR? Então, o aluno B discordando de L, dá a seguinte resposta uns 40 anos eu acho. Notamos que L, embora não 
concordasse com seu colega, não tinha certeza da data do surgimento do celular, assim utilizou uma construção que restringiu sua opinião. A função que essa tática atenuadora exerce é a de auto-proteger a face do locutor, pois ao dizer eu acho, isto é, não tenho certeza do que estou dizendo, o falante retira a responsabilidade sobre sua própria enunciação e se, por acaso, sua resposta estivesse incorreta, como de fato estava, evita colocar sua face positiva em risco.

Em relação ao emprego de partículas e construções justificadoras do dizer, verificamos também somente uma ocorrência no corpus de português e nenhuma no corpus de italiano.

O fragmento abaixo evidencia a confusão e a consequente discordância do aluno R em relação à conexão que ele havia estabelecido mentalmente sobre o surgimento das fábricas e do telefone que ele havia confundido com celular. No trecho abaixo, ele usa uma construção justificadora do dizer para tentar explicar porque não estava concordando com o que a professora estava falando naquele momento.

\section{FRAGMENTO DIS-PT n ${ }^{\circ} 6$}

Prof PORT: AS FÁbricas de tecido ... são uma invenção ... do século dezoito do século dezenove... primeiro surgiram as fábricas... e o celuLAR só pode surgir agora recentemente há pouco mais de 15 anos por conta da:: revolução da tecnologia... então as pessoas se vestiam antes os carros exisTIam:: não é? a energia elétrica surgiu no início do século... vinte

$R$ : mas é que eu pensei... ahn... se existiam as FÁbricas existia já um telefone

Prof PORT: MAS O TELEFONE EXISTE... o:: Bolacha não ligou para o gerente?

$R$ : ENTÃO? ((fez um gesto de confirmação com os braços abertos))

Prof PORT: não o celular ... existia o telefone

Podemos notar que R, ao expressar sua discordância, atenua-a com uma tática reparadora, colocando a responsabilidade da discordância não exatamente no que a professora disse, mas no que ele havia entendido sobre o dizer da professora. Dessa forma, tenta reparar os possíveis efeitos negativos da sua discordância, explicando o seu raciocínio. Essa estratégia relaciona-se mais com a salva-guarda da própria imagem do que com a preocupação da imagem do interlocutor, uma vez que $\mathrm{R}$ explicando-se, tenta proteger a própria imagem pública a fim de que ela seja reconhecida e valorizada dentro da sala de aula. 
3.2.6 Verbos, construções verbais e partículas discursivas com valor modal; modificadores externos e estruturas sintáticas condicionais, concessivas ou temporais

Vamos destacar agora alguns procedimentos atenuadores que foram encontrados somente nos atos de discordância em italiano: verbos, construções verbais e partículas discursivas com valor modal que expressam opinião em forma de dúvida ou de probabilidade (VI); modificadores externos como difusores significativos (II) e estruturas sintáticas condicionais, concessivas ou temporais que modificam ou restringem o ato de fala $(\mathrm{XI})$.

Observamos no fragmento a seguir, extraído da aula de italiano, a utilização de uma partícula discursiva com valor modal que expressa opinião em forma de dúvida ou de probabilidade com a função atenuadora de reparação.

\section{FRAGMENTO DIS-IT $\mathbf{n}^{\circ} 5$}

Italiano

T: maestra noi rimaniamo DUE ORE nell':: autobus e:: ... però cosa facciamo? non ci sarà niENte là?

Prof IT: COME NON CI SARÀ NIENTE?

$T$ : nell'autobus sto dicendo

Prof IT: NIENTE ... potete dorMIre potete parLAre potete canTAre FORSE ... ci sarà un film... per vedere non so

\section{Tradução}

$T$ : professora nós ficaremos DUAS HORAS no:: ônibus e::... mas o que vamos fazer? não vai ter NAda lá?

Prof IT: COMO NÃO VAI TER NADA?

$T$ : no ônibus estou falando

Prof IT: NADA...vocês podem dorMIr vocês podem conVERsar vocês podem canTAr TALVEZ tenha um filme... para assistir não sei

Nesse trecho da aula, a professora conversava com os alunos sobre o passeio que eles fariam com a escola para o sítio "Carroção". Nessa ocasião, o aluno T fez a seguinte pergunta para a professora maestra noi rimaniamo DUE ORE nell':: autobus e.: ... però cosa facciamo? non ci sarà niENte là? [ professora nós ficaremos DUAS HORAS no:: ônibus e:.... mas o que vamos fazer? não vai ter NAda lá?].Notamos que a utilização do dêitico de lugar "là" para o aluno referia-se ao ônibus, isto é, o aluno queria saber o que eles faríam dentro do ônibus durante as duas horas de viagem. Porém a professora preencheu esse dêitico com outra referência e, assim, entendeu esse "là" como o lugar do passeio, isto é, o sítio. A partir disso, discordou do aluno com a seguinte pergunta COME NON CI SARÀ NIENTE?[COMO NÃO VAI TER NADA?] Em outras palavras, se os alunos estavam indo para o sítio para se divertir como seria possível não ter nenhuma atividade lá? $\mathrm{O}$ aluno $\mathrm{T}$ se explicou, imediatamente, dizendo nell' autobus sto dicendo [no ônibus estou falando]. Então a professora respondeu com 
ênfase NIENTE [NADA], mas logo começou a enumerar algumas possíveis atividades que poderiam ser realizadas dentro do ônibus NIENTE ... potete dorMIre potete parLAre potete canTAre FORSE ... ci sarà un film... per vedere non so. [NADA...vocês podem dorMIr vocês podem conVERsar vocês podem canTAr TALVEZ tenha um filme... para assistir não sei].

Notamos, assim, que a professora fez uso de uma partícula discursiva de probabilidade $\boldsymbol{F O R S E}$ para suavizar sua discordância em relação ao que ela havia entendido da enunciação do aluno. Desse modo, a atenuação exerceu a função de reparação de uma ameaça à face positiva do $\mathrm{T}$, pois, em um primeiro momento, a professora havia respondido de forma direta e enfática que não haveria atividade alguma dentro do ônibus, depois reconsiderou e emitiu sua opinião em forma de probabilidade, começando a enumerar algumas atividades, isto é, que seria possível cantar, dormir ou que talvez tivesse um filme para assistir, mas que ela não tinha certeza. Com isso, a professora reconsiderou a pergunta do aluno e se mostrou disponível para respondê-la o que, por sua vez, contribui para o estabelecimento e para a manutenção do equilíbrio das relações interpessoais em sala de aula.

Em relação à utilização de modificadores externos como difusores significativos para suavizar uma discordância, encontramos o seguinte exemplo:

\section{FRAGMENTO DIS-IT n ${ }^{\circ} 6$}

\section{Italiano}

Prof IT: LEGGEREMO questa poesia "La pace VErrà::"

Fo: NO.... la poesia no:::: ((quasi pregando))

$L$ : abbiamo già letto maestra

Prof IT: lo so

M: maEStra:: no::::: ((pregando $))$

Prof IT: perché non vi piace la poesia?

Fo: perché le poesie sono FALSE ((inizia a gesticolare e cambia il tono della voce per parlare)) ecco il passarinho che vola

Prof IT: NON È così
Tradução

Prof IT: VAMOS LER esta poesia "La pace VErrà::"

Fo: NÃO.... a poesia não:::: ((quase implorando))

$L:$ nós já lemos professora

Prof IT: eu sei

$M$ : profeSSOra:: não::::: ((implorando))

Prof IT: por que vocês não gostam de poesia?

Fo: porque as poesias são FALSAS ((começa $a$ gesticular e muda o tom de voz para falar)) olha o passarinho que voa

Prof IT: NÃO È assim

No desdobrar da aula de italiano, a professora avisou para os alunos que eles iriam ler uma poesia, então eles começaram a reclamar. Percebendo a insatisfação, a professora perguntou a eles porque não gostavam de poesia. $\mathrm{O}$ aluno Fo respondeu que, para ele, as poesias eram falsas e, em seguida, mudou o tom de voz e iniciou a recitar ecco il passarinho che vola gesticulando com os braços. A professora não concordou com o aluno sobre as poesias serem falsas e disse $N O N$ É così. Ao atenuar a discordância por meio do uso desse 
difusor de significado così, a professora manifestou sua opinião contrária à do aluno evitando ameaçar sua face positiva e, assim, causar qualquer tipo de tensão na relação entre os dois.

A utilização de estruturas sintáticas condicionais, concessivas ou temporais que modificam ou restringem o ato de fala atenuando-o pode ser observada no próximo fragmento:

\section{FRAGMENTO DIS-IT n $^{0}$}

\section{Italiano}

Prof IT: COS'È FEDE? chi può spiegare a $\mathrm{C}$ cos'è fede? non è la traduzione

$B$ : è una::.... [ a cosa credi $L$ : religione

Prof IT: fede e religione sono cose diVERse tu puoi avere una religione però... non credere

$S$ : credere in qualcosa

Prof IT: sì credere IN qualcosa avere fede è credere in qualcosa può essere una persona può essere un Dio può essere... ((ha lasciato la frase sospesa))

\section{Tradução}

Prof IT: O QUE É FÉ? quem pode explicar a C o que é fé? não é a tradução

$B$ : è uma::.... [ coisa que você acredita

$L$ : religião

Prof IT: fé e religião são coisas diFEREntes você pode ter uma religião mas... não acreditar

$S$ : acreditar em alguma coisa

Prof IT: sim acreditar EM alguma coisa ter fé é acreditar em algo pode ser uma pessoa pode ser um DEUS pode ser...((deixou a frase suspensa))

Esse fragmento foi extraído de um momento da aula em que acontecia a leitura da poesia. Os alunos se alternavam na leitura, quando a aluna $\mathrm{C}$ fez a seguinte pergunta: $\operatorname{COS}^{\prime} \dot{E}$ FEDE? referindo-se a uma palavra presente na poesia. Ao final da leitura a professora retomou a pergunta da aluna colocando-a para a classe. O aluno L respondeu que fé era religione. Então, a professora discordou do aluno dizendo: fede e religione sono cose diVERse. Na sequência, exemplificou sua discordância de maneira atenuada, dizendo tu puoi avere una religione però... non credere.

A professora restringiu o alcance do seu ato de fala quando o atenuou, por meio do emprego de uma estrutura sintática concessiva, isto é, afirmando que a pessoa pode ter uma religião e, na sequência, acrescentando um però, isto é, pode não ter fé. Dito de outra maneira, a professora discordou de L afirmando que fé e religião são coisas diferentes e, exemplificou, dizendo "você pode ter uma religião e não ter fé necessariamente". Essa tática atenua a força da discordância porque a professora ao discordar do aluno faz, em seguida, uma reparação, considerando o que o interlocutor falou para poder contestá-lo.

$\mathrm{Na}$ sequência, apresentaremos os atos de discordância em que não encontramos a presença de táticas atenuadoras. 


\subsubsection{Ausência de atenuação}

Notamos que os atos de discordância realizados em língua italiana apresentavam menos atenuação com respeito aos atos de discordância realizados em língua portuguesa. No corpus de italiano, encontramos cinco fragmentos de discordância sem atenuação e no corpus de português encontramos apenas um. Recordamos que a ausência de atenuação nem sempre está relacionada com a falta de cortesia verbal, mas, muitas vezes, está associada à urgência da comunicação. Briz e Albelda (2013) estabelecem a relação entre cortesia e atenuação da seguinte forma:

[...] a cortesia e atenuação são, muitas vezes, um casal, mas de conveniência; na interação, a não presença ou menor presença da estratégia linguística de atenuação não implica necessariamente menor cortesia ou descortesia [...] pode ser explicada a partir do conceito de maior ou menor imediatez comunicativa ou coloquialidade.

[(...) la cortesì y la atenuación son a menudo pareja, pero de conveniencia; en la interacción la no presencia o menor presencia de esta estrategia lingüística de atenuación no implica necessariamente menor cortesìa o descortesia (...) pueden explicarse a partir del concepto de mayor o menor inmediatez comunicativa o coloquialidad.] ( p. 296)

Dessa forma, observemos, primeiramente, os atos de discordância realizados em italiano sem uso de atenuadores para verificar se essa hipótese da imediatez da comunicação se verifica dentro do frame comunicativo ou se a falta de atenuação gera conflitos nas relações entre os interlocutores.

\section{FRAGMENTO DIS-IT n ${ }^{\circ} 8$}

\section{Italiano}

(o aluno Fo si alza, va verso la professoressa $e$ dice)

Fo: NO aspetta... dimmi se non [sembra baccalà?

Ra: não é

BACALHAU:: FO

Fo: OK ma dimmi se non sembra baccalà?

(prende il barattolo e lo fa vedere alla

professoressa)

Prof IT: NO NON SEMBRA baccalà

$R a$ : VOCÊ PARECE UM BACALHAU
Tradução

(o aluno Fo se levanta, vai até a professora e diz) Fo: NÃO espera... me diz se não[ parece bacalhau?

BACALHAU:: FO

$R a:$ não é

Fo: OK mas me diz se não parece bacalhau? (pega o vidro e mostra-o para a professora)

Prof IT: NÃO NÃO PARECE bacalhau $R a$ : VOCÊ PARECE UM BACALHAU 
$\mathrm{O}$ fragmento acima retrata um episódio que ocorreu alguns minutos antes de começar a aula de italiano, com a professora já em sala. A aluna Ra retirou de dentro de uma sacola um pote de vidro e entregou-o para a professora. Era um doce. O colega de classe Fo, vendo a cena, levantou-se, foi até a professora e lhe perguntou se aquilo, dentro do pote, não parecia bacalhau NO aspetta... dimmi se non [sembra baccalà? [NÃO espera... me diz se não [ parece bacalhau?] Antes de Fo terminar a frase, a aluna Ra ficou visivelmente irritada e discordou do colega, afirmando enfaticamente (em português) não é BACALHAU:: FO.

$\mathrm{O}$ aluno Fo disse $O K$, mas insistiu na pergunta para a professora $O K$ ma dimmi se non sembra baccalà?[OK mas me diz se não parece bacalhau?] A professora, então, também discordou de Fo dizendo NO NON SEMBRA baccalà [NÃO NÃO PARECE bacalhau]. A discordância tanto da aluna (realizada em língua portuguesa) como da professora (realizada em língua italiana) foi expressa de forma direta e sem atenuação. Nesse caso, a falta de atenuação não indicou fala de cortesia verbal e, portanto, não houve prejuízo na relação entre alunos e entre aluno e professora, porque, com a continuação do diálogo, percebemos que a professora disse para Fo que ele estava querendo "zoar" a aluna Ra (prendere in giro) e ambas, aluna e professora, não aceitaram a brincadeira de Fo, discordando da afirmação de que o doce pareceria um bacalhau.

Como podemos ver na continuação do diálogo, também houve outra discordância que não foi atenuada.

\section{FRAGMENTO DIS-IT nº 9}

Italiano

Prof IT: vuoi prendere in giro Ra

Fo: NO:::

Prof IT: tu vuoi prendere Ra in giro Sì TI Prof IT: você quer tirar sarro da Ra SIM TE CONOSCO
Tradução

Prof IT: você quer tirar sarro da Ra

Fo: NÃO:::

CONHEÇO

Esse fragmento é a continuação do fragmento anterior, no qual a professora afirma que o aluno Fo, dizendo que o doce parecia bacalhau, estava querendo tirar sarro de Ra tu vuoi prendere in giro $\mathrm{Ra}$ [você quer tirar sarro da Ra]. O aluno Fo discorda da professora com um NO::, pois, afinal, assumir que estava querendo zoar a colega colocaria a sua face positiva em risco, pois não é um comportamento socialmente aceito em sala de aula. No entanto, a professora discorda do aluno, afirmando tu vuoi prendere Ra in giro Sì TI CONOSCO [você quer tirar sarro da Ra SIM TE CONHEÇO]. Notamos que a falta de 
atenuação da discordância de Fo relaciona-se mais com a imediatez da comunicação do que com a falta de cortesia, uma vez que, o aluno estava discordando de uma afirmação que ameaçava sua face positiva. A professora, por sua vez ao insistir, colocou a face do aluno em risco novamente, mas ele não contestou mais e ficou em silêncio.

O próximo fragmento em que também não detectamos a presença de nenhum elemento atenuador no ato de discordância foi quando a professora e os alunos estavam discutindo sobre a obrigatoriedade de ir à escola com a camiseta do uniforme. A professora defendia a ideia de que o uso era obrigatório, mas dois alunos discordaram dessa afirmação, como podemos observar abaixo:

\section{FRAGMENTO DIS-IT n ${ }^{\circ} 10$}

\section{Italiano}

Prof IT: voi siete OBBLIGATI a portarla Fo: NO::

Prof IT: a scuola SÌ

$T$ : io non sono obbligato io l'ho sempre portata da casa quindi

Prof IT: allora ... va bene
Tradução

Prof IT: vocês são OBRIGADOS a usá-la Fo: Não::

Prof IT: na escola SIM

$T$ : eu não sou obrigado eu sempre a levei para casa então

Prof IT: então ... tá bom

Observamos, nesse trecho, que a professora dizia para os alunos que eles eram obrigados a, pelo menos, usar a camiseta do uniforme para ir à escola. Nesse instante, o aluno Fo discordou de forma enfática e direta com um $\mathbf{N O}$. A professora insistiu e disse que para ir à escola eles eram obrigados sim a usar a camiseta do uniforme. Nesse momento, o aluno T também discordou da professora e disse sem o uso de qualquer tática atenuadora io non sono obbligato io l'ho sempre portata da casa quindi [eu não sou obrigado eu sempre a levei para casa então]. Notamos que, embora o aluno T não atenue sua discordância, ele a justifica dizendo que sempre manteve a camiseta do uniforme em casa, logo, não era obrigado a usá-la para frequentar a escola. Dessa forma, percebemos que os alunos ameaçam a face positiva da professora questionando a veracidade de uma informação transmitida por ela. A professora poderia entender isso como um questionamento da sua autoridade em sala de aula e, em decorrência, gerar conflito na interação e na relação entre alunos-professora, mas, ao invés disso, ela aceitou os fatos e encerrou o assunto.

Ainda no decorrer da aula de Italiano, surgiu uma polêmica entre alguns alunos sobre o uso da expressão alle volte. $\mathrm{O}$ tema nesse momento era o debate sobre a seguinte frase: Le bambine e $i$ bambini hanno diritto a essere ascoltati (meninos e meninas possuem o direito de 
serem ouvidos). A professora havia perguntado para os alunos se eles se sentiam ouvidos pelos adultos e, em caso afirmativo, em quais situações e com qual frequência.

\section{FRAGMENTO DIS-IT n ${ }^{\circ} 11$}

Italiano

Prof IT: F pensi:: cosa senti gli adulti ti sentono? ti asCOLtano?

$B$ : secondo me ... alle volte

Prof IT: alle volte

$T$ : a volte (( fa una correzione gramaticale))

Fo: anche alle volte

Prof IT: B cosa vorresti? essere più sentito più ascoltato dagli altri?

((B fa un segno affermativo con la testa. $C$ e $M$ stanno con le braccia alzate))

Prof IT: PROSSIMO M vai cosa?

$M$ : maestra io mi sento ascoltata alle volte

Prof IT: alle volte

$B$ : viu? $\mathbf{T} \mathbf{T}$ alle volte

$T$ : no A VOLTE

$F o$ : a volte e alle volte però alle volte [ è più

T:MACCHÉ
ALLE VOLTE

Fo: sì può dire... si dice

\section{Tradução}

Prof IT: F pensa:: o que você sente os adultos te ouvem? te esCUtam?

$B$ : eu acho que ... às vezes

Prof IT: às vezes

$T$ : às vezes ((faz uma correção gramatical $))$

Fo: também as vezes

Prof IT: B o que você gostaria? de ser mais ouvido mais escutado pelos outros?

((B faz um sinal afirmativo com a cabeça. $C e$ $M$ estão com os braços levantados))

Prof IT: PRÓXIMO M vai o quê?

$M$ : professora eu me sinto mais escutada às vezes

Prof IT: às vezes

$B$ : viu? $\mathbf{T} \mathbf{T}$ às vezes

$T$ : não às vezes

$F_{O}$ : às vezes $\mathrm{e}$ às vezes mas às vezes [ é mais

CLARO QUE NÃO ÀS VEZES

\section{$T:$}

$\mathrm{O}$ aluno $\mathrm{B}$ respondeu à pergunta da professora com a frase secondo me ... alle volte. Ao empregar a expressão alle volte (às vezes) que a professora repetiu na sequência, o aluno $\mathrm{B}$ foi imediatamente corrigido por $\mathrm{T}$, que discordou do uso da expressão, julgando-a como incorreta e afirmando que o correto seria a volte. O aluno Fo, ouvindo a correção feita por T, disse que em italiano era possível também usar a expressão alle volte e que seu uso não estaria incorreto.

A professora continuou a interação com os outros alunos da classe e dirigiu a mesma pergunta para a aluna $\mathrm{M}$, que forneceu a mesma resposta do aluno $\mathrm{B}$, isto é, usou também a expressão alle volte. Ouvindo isso, o aluno B, que havia sido corrigido por $\mathrm{T}$, voltou-se para ele e disse viu?(em português) $\boldsymbol{T}$ T alle volte. Então o aluno T apressou-se em manifestar sua discordância novamente, de forma direta e não atenuada, repetindo que o correto seria a volte. Fo não concordou e disse mais uma vez que as duas expressões estavam corretas $\boldsymbol{a}$ volte $\boldsymbol{e}$ alle volte, però alle volte è più... Nesse instante, é interrompido por T que enfaticamente insiste na sua opinião MACCHÉ ALLE VOLTE, ao passo que Fo também insiste sì può dire... si dice. 
Há, nesse trecho da aula, três opiniões diferentes e cada aluno discorda da opinião do outro de forma direta e não atenuada. Os alunos não usam atenuadores para suavizar a força do ato ilocucionário da discordância e, através da interação verbal, entra em jogo a tentativa de cada um de preservar a própria face e, como consequência, ameaçam a face positiva uns dos outros. Notamos também que, nesse momento, a falta de atenuação quase ocasionou um conflito entre os alunos, pois estavam em um forte embate para defender suas opiniões e não manifestavam cuidado com a face dos interlocutores. A discussão só se encerrou a pedido da professora.

O último fragmento, encontrado na aula de italiano que retrata uma discordância realizada sem atenuação, ocorreu durante o trabalho de compreensão do texto sobre os direitos das crianças. A professora pediu aos alunos que observassem o título Ehi ci state a sentire? E que identificassem a voz presente no texto. A partir disso, temos o seguinte diálogo:

\section{FRAGMENTO DIS-IT n ${ }^{\circ} 12$}

\section{Italiano}

Prof IT: millenovecentottantanove perfetto ALLORA a partire da questa informazione e ... dal titolo che avete EHI CI STATE A SENTIRE chi sta parlando? qual è la voce?

Fo: i bambini

Prof IT: i bambini perché? come lo sai Fo?

$F o$ : perché qua ci stanno i diritti dei bambini T: NO:: ma...

Prof IT: Il titolo Ehi ci state a sentire

$S$ : noi.. è::... dovete consideRARci

$M$ : dovete ascoltare no

Prof IT: NO NO non è un'altra versione del titolo... COME sapete che è un bamBIno che sta o che sono i bamBIni che stanno dicendo EHI ci state a sentire

$S$ : perché di solito i grandi non ascoltano i piccoli

Prof IT: AH di solito i grandi non ascoltano i piccoli? ((sorrisi)) COME LO SAI S?

$S$ : perché quando le persone stanno a parlare dei grandi non ascoltano MA:::i i piccoli

Prof IT: AH:: è quello che vivi dove? a sCUola a CAsa?

$S$ : dappertutto

Prof IT: DAPPERTUTTO? non ti senti sentito dagli altri?

((S fa un segno negativo con la testa $))$
Tradução

Prof IT: mil novecentos e oitenta e nove perfeito ENTÃO a partir desta afirmação e... do título que vocês EHI CI STATE A SENTIRE quem está falando? qual é a voz?

Fo: as crianças

Prof IT: as crianças por que? como você sabe Fo?

Fo: porque aqui estão os direitos das crianças

$T$ : NÃO:: mas...

Prof IT: O título Ehi ci state a sentire

$S$ : nós.. é::... vocês devem nos consiDERAR

$M$ : vocês devem escutar não

Prof IT: NÃO NÃO não é uma outra versão do título... COMO vocês sabem que é uma criANça que está ou que são criANças que estão dizendo EHI vocês estão nos ouvindo

$S$ : porque geralmente os adultos não ouvem as crianças

Prof IT: AH geralmente os adultos não ouvem as crianças? ((risos)) COMO VOCÊ SABE S?

$S$ : porque quando as pessoas estão falando com os adultos NUN:ca ouvem as crianças

Prof IT: AH:: isso você vive onde? na esCOla em CAsa?

$S$ : em toda parte

Prof IT: EM TODA PARTE? Você não se sente ouvido pelos outros?

((S faz um sinal negativo com a cabeça $))$ 
L: neanche da professoressa? ((dice il nome della professoressa))

(( fa un segno negativo con la testa $)$ )

Prof IT: AH:::: che BUGIA ahn ((frase esclamativa))
$L$ : nem mesmo pela professora? ((fala o nome da professora))

((S faz um sinal negativo com a cabeça $)$ )

Prof IT: AH:::: que MENTIRA ahn ((frase exclamativa))

Fo responde que a voz presente no texto era a voz das crianças. Já o aluno $\mathrm{S}$ disse que a partícula "ci" presente no título referia-se a "nós" e completou noi.. è:.... dovete consideRARci. Nesse momento, a professora deixa claro que não queria uma outra versão do título e pergunta como os alunos sabíam que eram crianças que estavam falando.

O aluno S diz que era porque, normalmente, os adultos não escutam as crianças. A professora achou graça e perguntou a ele como sabia disso. S explicou que, quando as pessoas estão falando, os adultos nunca ouvem as crianças. A professora perguntou, então, onde S vivia aquilo, se na escola ou em casa e o aluno deu a seguinte resposta dappertutto[em toda parte]. A professora, surpresa, repetiu DAPPERTUTTO? E acrescentou non ti senti sentito dagli altri? [EM TODA PARTE? Você não se sente ouvido pelos outros?] $\mathrm{O}$ aluno S balançou negativamente a cabeça.

Nesse instante, o aluno F perguntou ao colega S neanche da professoressa? ((falou o nome da professora)) [nem mesmo pela professora?] e $\mathrm{S}$ faz novamente um gesto negativo com a cabeça. A professora, então, sentiu essa afirmação como um ataque à sua face positiva e discordou fortemente da opinião de $\mathrm{S}$ dizendo que aquilo era uma mentira AH:::: che BUGIA ahn [AH:::: que MENTIRA ahn]. Podemos observar que, ao sentir-se ofendida pela afirmação do aluno, a professora o ofendeu também, isto é, atacou a face positiva dele, afirmando que ele estava mentindo. Nesse caso, a falta de atenuação colocou em risco as relações interpessoais em sala de aula, relacionando-se à descortesia verbal.

Desse modo, através da análise dos fragmentos apresentados, verificamos que, em alguns atos de discordância realizados tanto pela professora de italiano quanto por alunos nativos italianos e brasileiros, não houve a utilização de atenuação. Em alguns momentos, a falta de atenuadores esteve relacionada à urgência da comunicação (fragmentos 8 e 9), enquanto em outros revelou pouca preocupação em manter o equilíbrio das relações verbais, isto é, não houve o cuidado necessario com a face positiva do interlocutor (fragmentos 10,11 e 12), o que, por sua vez, se aproxima mais da descortesia.

Já na aula de Português, o único momento em que observamos a ausência de atenuação em um ato de discordância foi o seguinte: 


\section{FRAGMENTO DISC-PT nº 14}

Prof PORT: ele sobreviveu a um tiro na barriga e um balde de água fervendo na cabeça:: hein... o cara é poderosíssimo

$F$ : dá a entender no SEU CARA tipo no seu segurança

Prof PORT: seu cara NÃO ESSE CARA na cara do gerente

$F$ : eu sei

Essa interação ocorreu após a leitura do seguinte trecho da narrativa do livro $O$ Gênio do Crime:

Senhor gerente- interrompeu o Mister.- Mim ser um homem muitíssimo do calmo, mim só perder o meu paciência uma vez no vida com uma bandida espanhol que amarrar mim numa cadeira me dar um tiro no meu barriga e depois jogar um balde de água fervendo no meu cabeça. Mas o senhor estar muito chato, senhor gerente, se o senhor repetir mais uma vez." eu disse" mim dar um tapa no seu cara.

A professora retomava a compreensão da leitura dizendo que o personagem do Mister sobreviveu a um tiro na barriga e um balde de água fervendo na cabeça:: hein... o cara é poderosíssimo, quando o aluno $\mathrm{F}$, apoiando-se na fala do personagem (um escocês, que não fala muito bem o português), disse que a seguinte frase do Mister: mim dar um tapa no seu cara, abria margem para outra possibilidade de compreensão e afirmou o seguinte: dá a entender no SEU CARA tipo no seu segurança. Nesse instante, a professora discordou do aluno de forma direta e sem atenuação, afirmando seu cara NÃO ESSE CARA na cara do gerente. Em outras palavras, o termo "cara" na narrativa fazia referência ao rosto do personagem e não a cara como substantivo que se refere a homem. Desse modo, podemos atribuir a discordância direta e não atenuada da professora à necessidade imediata de comunicação, isto é, de não deixar o aluno entender de forma equivocada aquele trecho da narrativa, portanto, nesse caso, a ausência de atenuação não caracteriza uma descortesia verbal.

A seguir apresentamos a análise e a discussão dos atos de desaprovação realizados em português e italiano.

\subsection{DESAPROVAÇÃO}

Ao analisarmos os atos de desaprovação presentes na interação em sala de aula, verificamos que eles aconteceram, principalmente, na relação entre professor-aluno(s). 
Encontramos somente dois exemplos em que a desaprovação ocorreu na interação aluno(s)aluno(s) em sala de aula. Ao analisar os dados, constatamos tanto a presença de estratégias atenuadoras quanto a ausência delas nos atos de desaprovação realizadas em português e em língua italiana.

As estratégias atenuadoras mais utilizadas em língua portuguesa pelos falantes, para minimizar o ato de desaprovar foram: a indiretividade (IX) e as formas apelativas convencionalizadas (XX). Já em língua italiana as estratégias mais utilizadas foram também a indiretividade (IX) e as partículas discursivas e expressões de controle e de contato com o interlocutor (XIX).

A tática mais encontrada nos dois corpora de atos de desaprovação, tanto o de língua portuguesa quanto o de língua italiana foi a indiretividade, isto é, a desaprovação expressa indiretamente, por meio de perguntas e afirmações.

Para que possamos entender como essa estratégia foi utilizada e seus efeitos na interação em ambas as línguas, apresentaremos, a seguir, os exemplos.

\subsubsection{Indiretividade}

Como vimos, a desaprovação configura-se em um tipo de ato diretivo. Albelda (2010) faz uma distinção entre atos diretivos que expressam pedido (ordens, perguntas, proibições, solicitações; em outras palavras, atos que se realizam em benefício do eu) e os que expressam conselho (atos que se realizam em benefício do tu). No caso dos diretivos que buscam o benefício para o ouvinte, segundo a autora, costuma ser menos frequente a utilização de atenuação. Já os mecanismos para atenuar os atos diretivos em benefício do eu são mais numerosos e diversos. Entre eles a autora cita as perguntas indiretas (ALBELDA, 2010, p. 04).

Como os atos de desaprovação geralmente configuram-se em pedidos ou ordens, podemos dizer que as desaprovações são atos diretivos que se realizam em benefício do $e u$. Ao analizarmos os atos de desaprovação presentes em nosso corpus, percebemos uma forte presença da indiretividade, caracterizada pelo uso de perguntas indiretas ou afirmações, como forma de manifestar uma desaprovação por um determinado tipo de comportamento.

O primeiro fragmento que será apresentado retrata o momento da aula, em que a professora de italiano falava sobre a excursão que os alunos fariam com a escola. Nesse momento, ela perguntou para os alunos quem já havia entregado a ficha médica, necessária 
para o passeio. $\mathrm{O}$ aluno $\mathrm{T}$ levantou a mão e disse que não a havia entregue ainda e explicou que sua mãe estava na Itália, mas que poderia pedir para o seu pai. Nesse instante, a professora pergunta por que ele ainda não havia feito isso:

\section{FRAGMENTO DES-IT n ${ }^{\circ} 1$}

\section{Italiano}

T: IO la ficha medica io non l'ho

Prof IT: non l'hai consegnata?

$T$ : non ANCORA perché la mia mamma è in Italia e:: mio padre me lo sono dimenticato di dirlo che deve firmare per domani

Prof IT: ASPETTA quando torna la tua mamma?

$T$ : torna venerdì notte

Prof IT: e AVRÀ tempo di compilare i dati?

$T$ : no... credo di no ma la posso chiedere a mio padre [anche se

Prof IT: E PERCHÉ NON L'HAI ANCORA fatto?

$T$ : lui non è uno molto organizzato sai?

((la professoressa sorride))

\section{Tradução}

$T$ : EU a ficha médica eu não tenho

Prof IT: você não a entregou?

$T$ : não AINDA porque a minha mãe está na Itália

e:: meu pai eu esqueci de falar para ele que ele tem que assinar para amanhã

Prof IT: ESPERA quando sua mãe volta?

$T$ : volta sexta-feira de madrugada

Prof IT: e ela VAI TER tempo de preencher os dados?

$T$ : não... acho que não ma eu posso pedir para o meu pai [apesar de

Prof IT: E POR QUE VOCÊ AINDA NÃO fez isso?

$T$ : ele não é muito organizado sabe?

((a professora sorri))

A professora pergunta a $\mathrm{T}$ quando a mãe dele retornaria a São Paulo e se haveria tempo para preencher a ficha médica. $\mathrm{O}$ aluno responde que ela chegaria na sexta-feira daquela semana, de madrugada, e que, provavelmente, não teria tempo de preencher a ficha, no entanto, ele poderia pedir para o seu pai. Ao ouvir isso, a professora o interrompe e lhe pergunta E PERCHÉ NON L'HAI ANCORA fatto? [E POR QUE VOCÊ AINDA NÃO fez isso?]

Podemos inferir, a partir do contexto e da entonação de voz utilizada pela professora, que a pergunta dela não era somente uma tentativa de obter mais informações, isto é, um desejo de saber por qual motivo o aluno ainda não havia pedido para o seu pai preencher e assinar a ficha, mas tratava-se de uma manifestação implícita de desaprovação em relação ao comportamento do aluno que, sabendo como deveria agir, não o tinha feito ainda e isso poderia impossibilitar a sua ida ao passeio.

Sobre o processo de inferência que nos permitiu entender a pergunta da professora como uma manifestação indireta e atenuada de desaprovação, Escandell Vidal afirma "nós desenvolvemos mecanismos de inferência complexos que entram em funcionamento automaticamente para recuperar o que nossos interlocutores queriam dizer a partir daquilo que 
eles realmente disseram."[Hemos desarrollado complejos mecanismos de inferencia que entran en funcionamiento automáticamente para hacermos recuperar lo que nuestros interlocutores quisieron decir a partir de lo que realmente dijeron] (ESCANDELL VIDAL, 1996, p. 17).

Desse modo, na pergunta da professora (o que ela disse) estava implícita (o que ela queria dizer) uma desaprovação, na qual o comportamento que estava sendo julgado era a possível falta de responsabilidade do aluno em cumprir um requisito essencial para a sua participação em uma atividade extra-curricular oferecida pela escola. A atenuação da força ilocucionária do ato de desaprovar através do emprego da indiretividade disfarça a desaprovação e permite que ela seja interpretada como um pedido de informação. Dessa forma, a ameaça às faces positiva e negativa do aluno é minimizada, isto é, o aluno não sente diretamente que seu comportamento está sendo criticado e nem que sua liberdade de escolha está sofrendo imposição. Tanto é verdade que o aluno não percebe a desaprovação e responde à pergunta da professora como se tivesse sido um pedido de informação lui non è uno molto organizzato sai? A professora então sorri com a resposta.

O fragmento DES-IT $n^{\circ} 2$ também retrata a manifestação indireta da desaprovação em sala de aula. Nesse momento, enquanto a professora de italiano trabalhava a compreensão de uma poesia com os alunos, a aluna A havia retirado uma folha do seu caderno e estava recortando-a. A professora, quando percebe o que estava ocorrendo, interrompe sua própria fala e desaprova o comportamento da aluna da seguinte forma:

\section{FRAGMENTO DES-IT n ${ }^{\circ} 2$}

\section{Italiano}

Prof IT: di essere rispettato solo? c'è un ALtro anche qua

$R a$ : di giocare?

$S$ : credo di non avere più freddo

$R:$ avere la pace?

Prof IT: STUDIARE LA LEZIONE CON L'ANIMO TRANQUILLO LA PACE VERRÀ SULLA TERRA allora l'animo tranquillo la pace verrà O::::: A per favore no? (( la studentessa $A$ aveva strappato un foglio dal quaderno e stava tagliandolo, dimostrando mancanza di attenzione a ciò che accadeva in classe))
Tradução

Prof IT: de ser respeitado só? tem um OUtro também aqui

$R a$ : de brincar?

$S:$ acho que de não ter mais frio

$R$ : ter paz?

Prof IT: ESTUDAR COM ESPÍRITO TRANQUILO A PAZ VIRÁ SOBRE A TERRA então o espírito tranquilo a paz virá O::::: A por favor né? (( aluna A havia arrancado uma folha do caderno e estava recortando-a, mostrando desatenção com relação aquilo que estava acontecendo na aula)) 
Observa-se que a professora chamou a aluna pelo nome e desaprovou o fato dela não estar atenta na aula e estar envolvida em outra atividade (recortando um papel). A professora atenuou sua desaprovação, expressando-a de forma indireta $O::::$ : A per favore no? Podemos notar também a utilização da expressão per favore que atenua também a desaprovação da professora. Assim, através da formulação indireta e da utilização de uma expressão convencionalizada de cortesia, a professora enfraqueceu a força ilocucionária da desaprovação. Escandell Vidal (1996) escreve:

\begin{abstract}
A cortesia torna-se o princípio que justifica o uso de formas indiretas. Elas resultam mais corteses, porque não impõem uma obrigação, mas "fingem" abrir ao ouvinte a possibilidade de executar ou não o ato solicitado. Isso explica por que sua utilização é restrita quase que exclusivamente aos atos inerentemente descorteses.

[La cortesía se convierte en el principio que justifica el empleo de formas indirectas. Éstas resultan más corteses porque no imponen una obligación, sino que "fingem" abrir al oyente la posibilidad de realizar o no el acto solicitado. Ello explica que su uso se restrinja casi exclusivamente a los actos inherentemente descorteses.] (p. 146)
\end{abstract}

Dessa forma, a aluna pode entender a desaprovação indireta como um "pedido" da professora para voltar a prestar atenção na aula e, assim, como escreveu Escandell Vidal, a aluna teve a impressão de poder escolher executar ou não a solicitação da professora. $\mathrm{Na}$ sequência, observamos que a aluna guardou o papel e a tesoura e voltou a prestar atenção na aula. Desse modo, a professora realizou uma desaprovação atenuada e cortês, evitando ameaçar as faces positiva e negativa da aluna. Embora o comportamento da aluna tenha sido desaprovado, ele não foi criticado, o que já preserva a face positiva da aluna. Já a face negativa foi preservada quando a imposição foi mascarada pela indiretividade do "pedidodesaprovação". Sobre a face negativa:

refere-se à necessidade que todo indivíduo tem de ser independente, de ter liberdade de ação e de não sofrer imposição. Envolve a contestação básica aos terrítórios, reservas pessoais e direitos; em outras palavras, a liberdade de ação e liberdade de sofrer imposição; o desejo que as pessoas têm de não serem controladas. É o desejo de não ser impedido em suas ações, por isso a preservação da face negativa implica a não imposição do outro. Salienta-se que, em geral, as pessoas não querem ser controladas ou impedidas pelos outros. (SILVA, 2008, p. 179)

Em outro momento da aula de italiano, a mesma aluna mostrou-se, novamente, distraída. Durante a leitura de um texto, realizada por um colega de classe, ela olhava 
fixamente para ele, ao invés de acompanhar a leitura no seu livro. Então, a professora desaprovou esse comportamento da seguinte forma:

\section{FRAGMENTO DES-IT n $^{\circ} 3$}

\section{Italiano}

((G inizia la lettura $))$

"Le bambine e $i$ bambini hanno diritto a essere curati, nutriti e protetti da chi li vuole far lavorare duramente, da chi gli vuol far fare il soldato nelle feroci guerre degli adulti, da chi gli vuol fare del male"

((Durante la lettura, la professoressa disapprova il comportamento di A che stava guardando $G$ al posto di seguire la lettura sul suo libro))

Prof IT: A SEI QUA o in un altro posto?

( $l$ 'alunna si volge)

$S$ : nel mondo delle favole

\section{Tradução}

((G inicia a leitura $))$

"Le bambine e i bambini hanno diritto a essere curati, nutriti e protetti da chi li vuole far lavorare duramente, da chi gli vuol far fare il soldato nelle feroci guerre degli adulti, da chi gli vuol fare del male"

((Durante a leitura, a professora reprova o comportamento de A que olhava para $G$ ao invés de acompanhar a leitura no seu livro))

Prof IT: A VOCÊ ESTÁ AQUI ou em outro lugar?

(a aluna vira-se para frente)

$S$ : no mundo das fábulas

A professora fez uso, mais uma vez, da indiretividade, para manifestar sua desaprovação em relação ao comportamento da aluna. Relembramos que a professora é a pessoa que rege "regista" a interação em sala de aula, portanto, é responsável por organizar as interações e por julgar se o comportamento dos alunos está adequado ou não dentro do ambiente social no qual ocorre a troca comunicativa.

Portanto, quando a professora disse $A$ SEI QUA o in un altro posto? [A VOC $\hat{E}$ ESTÁ AQUI ou em outro lugar?] a referência da dêixis de lugar "qua" é o ambiente de sala de aula, porém a professora não fazia referência ao fato da aluna estar naquele ambiente fisicamente, mas sim mentalmente, acompanhando e participando da atividade que ocorria naquele momento. Dessa forma, a professora, percebendo que a aluna estava engajada em outra atividade diferente daquela que estava sendo desenvolvida em sala de aula, desaprovou o comportamento da aluna perguntando se ela estava ali de fato. A aluna A compreendeu que a pergunta da professora era uma desaprovação implícita e mudou seu comportamento imeditamente, virando-se para a frente e acompanhando a leitura no livro.

No próximo fragmento, temos outro exemplo de desaprovação indireta. Neste momento da aula de italiano, a professora já havia desaprovado, duas vezes, o comportamento do aluno $\mathrm{F}$, por ele estar conversando e, consequentemente, desatento àquilo que estava acontecendo na aula. 
Os alunos trabalhavam com um texto sobre os direitos das crianças e a aluna $\mathrm{M}$, apoiada nesse texto, dizia que era direito das crianças ir à escola, aprender a ler, a escrever e estudar. Nesse instante, a professora olhou para o aluno F e percebeu que ele estava distraído, observando o teto da sala de aula, então disse:

\section{FRAGMENTO DES-IT n $^{\circ} 4$}

\section{Italiano}

$M$ : quindi deve andare a scuola e a imparare a leggere e... a scrivere e... a studiare

Prof IT: VA BENE F ? un bambino deve avere l'opportunità di andare a scuola per imparare a leGGEre a sCRIvere vero?

$F$ : sì

Prof IT: ah::... sì e deve approfiTTAre l'opportunità approfittarsi dell'opportunità
Tradução

$M$ : então devi ir à escola e aprender a ler e... a escrever e.... estudar

Prof IT: CERTO F? uma criança deve ter a oportunidade de ir à escola para aprender a LER e a esCREver certo?

$F:$ sim

Prof IT: ah::... sim e deve aproVEItar a oportunidade

Reparamos que a enunciação da professora, além de retomar o que a aluna $\mathrm{M}$ havia falado, tem como objetivo desaprovar o comportamento de F, que se mostrava distraído e desinteressado na aula. A professora usou o trecho do texto que a aluna $\mathrm{M}$ havia acabado de ler e o transformou em pergunta para o aluno F, como forma de desaprovar seu comportamento. Com esse procedimento, como já vimos, a professora atenua a força ilocucionária do ato de desaprovar exprimindo-o de forma implícita e assim, evitando conflitos interacionais.

A professora utilizou também outro recurso atenuador que é a impessoalização. Quando perguntou para $\mathrm{F}$ se ele concordava com o que havia sido falado pela aluna M VA BENE F ? E prosseguiu: un bambino deve avere l'opportunità di andare a scuola per imparare a leGGEre a SCRIvere vero? [CERTO F? uma criança deve ter a oportunidade de ir à escola para aprender a LER e a esCREver certo?] Ao utilizar a expressão un bambino a professora impessoalizou sua enunciação, pois, com o uso geral da palavra criança, seu objetivo era referir-se a uma criança em particular, isto é, ao aluno F. Assim, a professora fingiu dirigir um enunciado ameaçador a um outro que não era aquele a quem esse enunciado, verdadeiramente, se destinava. Tal mecanismo é autoprotetor, uma vez que minimiza as responsabilidades do falante sobre a enunciação. Sobre a impessoalização Albelda et al. escrevem: 
Um dos procedimentos mais recorrentes na atenuação é a impersonalização do sujeito semântico (o agente). O falante responsável pelo que é dito está escondido em outro, em um interlocutor geral ou no julgamento da maioria; se desfoca assim a fonte da enunciação e se mascara a enunciação pessoal. [Uno de los procedimientos más recurrentes en la atenuación es la impersonalización del sujeto semántico (el agente). El hablante responsable de lo dicho se oculta en otro, en un interlocutor general o en el juicio de la maioria; se desfocaliza asì la fuente de la enunciación y se difumina la enunciación personal.] (ALBELDA, 2014, p. 20)

Em outras palavras, é como se a professora se escondesse atrás do discurso de outra pessoa, ou seja, faz parecer que não é ela que está dizendo que as crianças devem ter a oportunidade de ir à escola para aprender a ler e a escrever, é o que está escrito no texto que os alunos estão lendo. No entanto, como a professora gostaria de dizer exatamente aquilo ao aluno L, usa a voz que está no texto para desaprovar o comportamento do aluno, e complementa dizendo ah::... sì e deve approfiTTAre l'opportunità approfittarsi dell'opportunità [ah::... sim e deve aproVEItar a oportunidade] . O aluno F entendeu o que a professora estava querendo dizer, de forma implícita, ou seja, que ele, tendo esse direito, deveria saber aproveitá-lo e não desperdiçar a oportunidade de aprender, conversando durante a aula ou distraindo-se com outras coisas. Notamos que a desaprovação, quando atenuada pela professora, diminui os efeitos negativos sobre os alunos e ajuda a preservar o equilíbrio das relações interacionais em sala de aula.

Em outra ocasião, a desaprovação também foi expressa indiretamente, mas não por meio de pergunta e sim por meio de uma afirmação. A professora de italiano desenvolvia a compreensão e a interpretação de dois gêneros textuais: poesia e texto descritivo-informativo. Após os alunos terem realizado a leitura silenciosa do texto descritivo-informativo, a professora perguntou a eles qual era o assunto do texto. $\mathrm{O}$ aluno $\mathrm{L}$ respondeu que o texto era sobre os direitos das crianças, então, a professora, retomando a poesia que já havia sido lida perguntou para a classe quais eram os direitos presentes, simultaneamente, na poesia e no texto descritivo-informativo.

Cada aluno enumerava um direito até que, em um determinado momento, o aluno $\mathrm{S}$ começou a ler a poesia em voz alta. A professora, imediatamente, desaprovou o seu comportamento, como pode ser observado a seguir: 


\section{FRAGMENTO DES-IT $n^{0} 5$}

Italiano

Prof IT: voi avete letto MOLti diritti che hanno i bambini quali sono i diritti UGUAli a quelli letti in quella poesia?

Gi: libertà

Prof IT: libertà

$M$ : PROtetti

Prof IT: protezione

$M$ : ISTRUZIONE

Prof IT: diritto all'istruzione

((S inizia a leggere la poesia ad alta voce mentre tutta la classe sta provando a rispondere la domanda della professoressa))

Prof IT: O:::::: S NON BASTA LEGGERE BISOGNA CAPIRE
Tradução

Prof IT: vocês leram MUItos direitos que as crianças possuem quais são os direitos iguais aqueles lidos naquela poesia?

$G i$ : liberdade

Prof IT: liberdade

M: PROtegidos

Prof IT: proteção

$M$ : INSTRUÇÃ̃O

Prof IT: direito à instrução

( $S$ começa a ler a poesia em voz alta enquanto toda a classe está tentando responder a pergunta da professora))

Prof IT: O:::::: S NÃO BASTA LER PRECISA ENTENDER

A seguinte afirmação da professora O::::: S NON BASTA LEGGERE BISOGNA CAPIRE [O:::::: S NÃO BASTA LER PRECISA ENTENDER] desaprovou indiretamente o comportamento do aluno $\mathrm{S}$, o qual, além de estar atrapalhando a participação dos demais colegas, falando ao mesmo tempo que eles, estava realizando uma atividade de leitura apenas. A utilização do ato indireto da afirmação, em vez do ato direto de ordenar que o aluno parasse de ler, suavizou a força do ato ilocucionário da desaprovação, prevenindo conflitos na relação aluno-professor e deixando a interação em sala de aula mais cortês.

A professora de italiano usou novamente a indiretividade em outro momento da aula, quando desaprovou o comportamento do mesmo aluno $\mathrm{S}$ que, na opinião dela, estava querendo saber demais sobre a excursão e, assim, estragaria a surpresa.

\section{FRAGMENTO DES-IT n ${ }^{\circ} 6$}

Italiano

$S$ : maestra quando ci sei andata quanto ci si può rimanere nell'aereo?

$C:$ che aereo?

Prof IT: è una sorpresa .... RIPETO LA STESSA COSA SE VOLETE SAPERE TUTTO PRIMA DI PARTIRE poi quando arrivati lì...
Tradução

$S$ : professora quando você foi quanto tempo pode ficar no avião?

$C$ : que avião?

Prof IT: é uma surpresa... REPITO A MESMA COISA SE VOCÊS QUISEREM SABER TUDO ANTES DE IR depois quando chegarem lá....

$\mathrm{O}$ aluno $\mathrm{S}$ tinha conhecimento de alguns detalhes sobre o passeio que o restante da classe não tinha e, sabendo que a professora já havia participado dessa mesma excursão no 
ano anterior, perguntou a ela quanto tempo eles poderiam ficar no avião. A aluna C estranhou a pergunta do seu colega, porque imaginava que o meio de transporte utilizado para chegar até o sítio seria o ônibus e não o avião, e disse che aereo? A professora, que não queria falar, para não revelar uma das atrações do passeio, limitou-se a dizer o seguinte é una sorpresa e, depois de uma pequena pausa, desaprovou o comportamento de $\mathrm{S}$ com a seguinte frase: RIPETO LA STESSA COSA SE VOLETE SAPERE TUTTO PRIMA DI PARTIRE poi quando arrivati lì... [é uma surpresa... REPITO A MESMA COISA SE VOCÊS QUISEREM SABER TUDO ANTES DE IR depois quando chegarem lá....]

Podemos notar que, na desaprovação realizada pela professora, estão presentes três procedimentos atenuadores. O primeiro deles, já mencionado anteriormente é a indiretividade, pois, por meio da afirmação, a professora, implicitamente, reprova a curiosidade do aluno de querer saber tudo sobre o passeio, inclusive o que deveria ser uma surpresa. O segundo procedimento atenuador refere-se ao uso da impessoalização. A professora, querendo desaprovar o comportamento de S, que na opinião dela estava querendo saber "demais", generalizou a desaprovação com o objetivo de impessoalizá-la, isto é, ao estender a desaprovação para todos os alunos, a professora diminuiu seu comprometimento com o próprio enunciado. $\mathrm{O}$ terceiro e último recurso utilizado por ela foi o de deixar a mensagem suspensa, para que os próprios alunos completassem-a mentalmente "quando chegarem lá..... não terá mais graça", por exemplo. Tal efeito atenuador é provocado pela elipse de conclusão, isto é, pela omissão de um termo da frase que não foi enunciado anteriormente, mas que podemos facilmente identificar pelo contexto. Deste modo, a professora desaprovou o comportamento "invasivo" do aluno de forma atenuada e cortês, evitando ameaçar a face positiva e negativa dele. Assim, alcança como resultado a manutenção do equilíbrio das relações em sala de aula.

No próximo fragmento da aula de italiano também podemos observar, mais uma vez, como a professora expressa a desaprovação de forma indireta.

\section{FRAGMENTO DES-IT $\mathbf{n}^{\circ} 7$}

Italiano

$C$ : quando.. è:: deve venire con uniforme?

Prof IT: ì QUELLO CHE HA PROPRIO DOMANDATO B

Fo: IO PURE VOLEVO chiederlo

Prof IT: mi ha appena domandato la stessa cosa

e gli ... gli ho detto di no
Tradução

$C$ : quando.. é:: tem que vir com uniforme?

Prof IT: É O QUE O B ACABOU DE PERGUNTAR

Fo: EU TAMBÉM QUERIA perguntar isso

Prof IT: ele acabou de me perguntar a mesma coisa e eu lhe... lhe disse que não 
((Fo celebra $))$

Prof IT: MA TU AMORE LA MAGLIETTA

DELLA SCUOLA NON LA PORTI VERO?
((Fo comemora $))$

Prof IT: MAS VOCÊ AMOR NÃO USA A CAMISETA DA ESCOLA VERDADE?

A classe ainda falava sobre a excursão para o sítio Carroção, quando a aluna C perguntou para a professora se eles deveriam usar o uniforme da escola no dia do passeio. A professora, antes de responder a pergunta da aluna, fez a seguinte observação: È QUELLO CHE HA PROPRIO DOMANDATO B [É O QUE O B ACABOU DE PERGUNTAR], ou seja, relembrou à aluna que seu colega de classe já havia feito essa pergunta anteriormente. Dessa forma, a professora estava desaprovando o fato de a aluna $\mathrm{C}$ não ter prestado atenção e ter perguntado novamente a mesma coisa.

No mesmo instante, o aluno Fo disse que também gostaria de perguntar isso, a professora repetiu, então, que o aluno B tinha acabado de fazer a mesma pergunta e que ela havia respondido que não, que não precisava usar uniforme no dia do passeio mi ha appena domandato la stessa cosa e gli... gli ho detto di no [ele acabou de me perguntar a mesma coisa e eu lhe... lhe disse que não]. Assim, a professora desaprovou, mais uma vez de forma indireta a falta de atenção dos alunos.

Na sequência, quando Fo ouviu da professora que não era necessário ir de uniforme ao passeio ele comemorou vibrando. A professora, então, desaprovou seu comportamento com a seguinte pergunta: MA TU AMORE LA MAGLIETTA DELLA SCUOLA NON LA PORTI VERO?[MAS VOCÊ AMOR NÃO USA A CAMISETA DA ESCOLA VERDADE?] ou seja, mais uma vez, de forma indireta, a professora desaprovou um comportamento, nesse caso, o fato de o aluno não usar uniforme nem mesmo para ir à escola, onde o uso seria obrigatório. A utilização de outros recursos atenuadores presentes nessa última fala da professora será analisada mais adiante.

O primeiro exemplo de ato de discordância da aula de Português, atenuado por meio da indiretividade ocorreu quando o aluno $\mathrm{R}$ perguntou para a professora qual era a diferença entre um telefone fixo e um celular. No trecho transcrito, a professora está explicando que o telefone fixo fica conectado a uma base.

\section{FRAGMENTO DES-PT $n^{\circ} 1$}

Prof PORT: R ele ESTÁ conectado à base do seu telefone... você chega em casa hoje e vai olhar $R$ : sim não tem cabo posso ir até meu quarto

Fo: é esse aqui:: ((faz um gesto com a mão indicando o tamanho do aparelho, mas $R$ não pode ver porque Fo está sentado atrás dele))

Prof PORT: você leva uma PARTE dele R 
$R$ : não entendi ainda

Prof PORT: você CARREGA na sua casa uma PARTE DELE a outra parte você tem que por pra carregar numa base... não tem?

$R: \operatorname{sim}$

Prof PORT: aquilo está CONECTADO a um ca:bo este cabo que faz a ligaÇÃO pra você poder se comunicar

((Fo fala algo baixinho e $R$ começa a rir $)$ )

Prof PORT: tudo bem? por que que você tá rindo?

$R:$ não sei

$((R$ continua rindo $))$

Prof PORT: tá tudo bem?... ãhn:: não tô entendendo porque você tá rindo

$R$ : eu começo a rir às vezes

Prof PORT: estranho isso né?... sem motivo

A partir da leitura do fragmento, podemos notar que, ao término da explicação da professora, o aluno Fo fala algo bem baixinho para o aluno R e ele começa a rir. A professora não percebeu o que Fo havia feito e por isso não sabia porque $\mathrm{R}$ estava dando risada, então perguntou a ele tudo bem? por que que você tá rindo? O aluno respondeu dizendo não sei. $\mathrm{E}$ como ele continuava rindo, isso começou a intrigar e a incomodar a professora, que não conseguia entender o motivo, já que ela não havia dito nada de engraçado. Então, a professora perguntou novamente tá tudo bem?... ãhn:: não tô entendendo porque você tá rindo. $\mathrm{O}$ aluno, querendo esconder o real motivo do riso, disse apenas eu começo a rir às vezes. Nesse instante, a professora desaprova o comportamento de R com a seguinte pergunta estranho isso né?... sem motivo.

Notamos que, no início da troca verbal, houve a curiosidade por parte da professora de tentar entender por que o aluno estava rindo, mas como ele se negava a dizer o motivo e não parava de rir, a professora, então, desaprovou seu comportamento, julgando-o como inadequado naquele momento. Ao realizar a desaprovação de maneira indireta, a força ilocucionária da desaprovação foi suavizada por meio da pergunta e pelo emprego de outra tática atenuadora que é a utilização da partícula de contato com o interlocutor né? Que cria uma relação de aproximação com o interlocutor, solicitando concordância com aquilo que foi dito.

Desse modo, a realização indireta da desaprovação por parte da professora revela o cuidado que ela tem com a preservação das relações em sala de aula. Embora desaprovasse o comportamento do aluno, não o repreendeu de forma direta, o que poderia ter um efeito negativo sobre o aluno, que poderia se sentir exposto diante dos demais alunos da sala, mas 
desaprovou seu comportamento de forma cortês, tentando conscientizá-lo de que sua atitude não era tida como adequada naquele momento.

Outro exemplo da aula de Português, em que a desaprovação foi expressa indiretamente, ocorreu quando a professora estava falando sobre as fábricas de tecido e o aluno $\mathrm{F}$ virou-se na cadeira para conversar com o aluno L durante a explicação da professora. Nesse momento, a professora interrompe sua fala, olha para cada um deles e desaprova tal comportamento da seguinte forma:

\section{FRAGMENTO DES-PT $n^{0} 2$}

Prof PORT: fala

Ra: 20 anos?

Prof PORT: isso gente o celular é uma invenção MUITO recente

F: ENTÃO por isso que eu falei 1988 ((nesse momento o aluno vira para trás e começa a conversar com seu coleguinha))

Prof PORT: AS FÁbricas de tecido ... elas são uma invenção ... do século deZEnove.. dezoito dezenove (( olha para o aluno $L)$ ) o::: estou falando ((olha para o aluno $F)$ ) o::: F estou falando

É notório que os alunos sabiam que a professora estava falando naquele momento e, portanto, a frase não é uma simples afirmação, mas constitui-se de um recurso para demonstrar desaprovação em relação ao comportamento dos alunos e, ao mesmo tempo, dar uma ordem indireta a eles, a de fazer silêncio. Para reconhecer uma desaprovação realizada de modo indireto, o interlocutor deve ativar uma implicatura conversacional, isto é, tentar identificar, naquilo que foi dito de modo explícito, as intenções do falante que estão presentes de forma implícita. Sbisà (2002) salienta que as inferências por meio das quais o ouvinte reconhece a intenção comunicativa do falante, são baseadas em crenças contextuais, crenças compartilhadas pelos falantes e ativadas pelo contexto de expressão.

O que é realmente invocado nas descrições de inferências por meio das quais o ouvinte reconhece a intenção comunicativa do falante são "crenças contextuais mútuas": crenças relevantes e ativadas pelo contexto de enunciado, ou pelo enunciado em si, que são compartilhadas e acreditadas pelos participantes.

[what is really invoked in descriptions of inferences by means of which the hearer recognizes the speaker's communicative intention are 'mutual contextual beliefs': beliefs relevant to and activated by the context of utterance, or by the utterance itself, that are shared and believed to be shared by the participants.] ( p. 422) 
Desse modo, o conhecimento do contexto de sala de aula e do que é ou não permitido fazer ali dentro é que possibilita aos alunos realizar a implicatura conversacional e entender a desaprovação. Durante a enunciação da professora, pudemos notar que, além do ato indireto, ela fez uso de elementos prosódicos (entonação da voz) e de elementos paralinguísticos (o olhar) que ajudaram também a suavizar a força ilocucionária da desaprovação expressa verbalmente.

No próximo trecho da aula de português reproduzido abaixo, observamos que a professora desaprovou o comportamento de alguns alunos da classe indiretamente, por meio da tentativa de estabelecer um diálogo com o aluno R.

\section{FRAGMENTO DES-PT n $^{\circ}$}

$R$ : UÉ qual é a diferença de um pro outro? ((os alunos estão falando ao mesmo tempo)) Prof PORT: EU NÃO CONSIGO te ouvir porque tem muita gente falando junto (( a classe se acalma e silencia $)$ )

Nesse fragmento, percebemos que o aluno R fez uma pergunta para a professora, mas, como os demais alunos da classe estavam conversando em voz alta, a professora não conseguiu escutar a pergunta de R. Então, sem pedir diretamente para a classe ficar em silêncio, a professora falou para R EU NÃO CONSIGO te ouvir porque tem muita gente falando junto. Imediatamente, os outros alunos entenderam que a professora estava pedindo (ou ordenando) silêncio para, não somente ouvir a dúvida de R, mas também para poder prosseguir a aula. Briz (2013) escreve que

um indivíduo é atenuadamente cortês para aproximar-se ou não, se afastar extremamente do outro e assim conseguir o objetivo, chegar com sucesso à meta, uma meta local (obter algo em um momento dado) ou global (conseguir o acordo ou minimizar o desacordo). (p. 286)

Notamos que a utilização dessa estratégia atenuadora, nesse contexto, alcançou com êxito o seu objetivo, isto é, o silêncio e, ao mesmo tempo, não ameaçou diretamente as faces positiva e negativa dos alunos que estavam conversando naquele momento.

Em todos os fragmentos apresentados anteriormente, observamos que a presença da atenuação suaviza um ato intrinsicamente ameaçador da face positiva e negativa do ouvinte (intrinsic FTA) como é o caso da desaprovação. As professoras, ao escolherem reduzir a força 
ilocucionária da desaprovação, tornam o ato de fala e a própria interação mais corteses. Percebemos que a desaprovação atenuada, realizada de maneira indireta, quando assume a forma de uma afirmação, exige que o interlocutor faça uma implicatura conversacional para tentar entender de forma implícita aquilo que o interlocutor disse de maneira explícita, é necessário fazer uma inferência para entender a desaprovação. Já quando a desaprovação é realizada de maneira indireta, sob a forma de perguntas, ela poderá, muitas vezes, ser entendida como um pedido. A desaprovação não atenuada poderá ser confundida com uma ordem.

\subsubsection{Partículas discursivas e expressões de controle e de contato com o interlocutor}

Outra tática também muito utilizada em língua italiana para atenuar os atos de desaprovação foi o uso de partículas discursivas e expressões de controle e de contato com o interlocutor, isto é, formas que atenuam os atos de fala solicitando o consentimento do interlocutor e evitando, assim um possível desacordo.

O fragmento abaixo, já apresentado anteriormente, contém uma expressão de controle e de contato do locutor com o interlocutor que contribui para suavizar a desaprovação.

\section{FRAGMENTO DES-IT $n^{0} 2$}

Italiano

Prof IT: di essere rispettato solo? c'è un ALtro anche qua

Ra: di giocare?

$S:$ credo di non avere più freddo

$R$ : avere la pace?

Prof IT: STUDIARE LA LEZIONE CON L'ANIMO TRANQUILLO LA PACE VERRÀ SULLA TERRA allora l'animo tranquillo la pace verrà O:::::: A per favore no? (( la studentessa A aveva strappato un foglio dal quaderno e stava tagliandolo, dimostrando mancanza di attenzione a ciò che accadeva in classe))
Tradução

Prof IT: de ser respeitado só? tem um OUtro também aqui

$R a$ : de brincar?

$S:$ acho que de não ter mais frio

$R$ : ter paz?

Prof IT: ESTUDAR COM ESPÍRITO TRANQUILO A PAZ VIRÁ SOBRE A TERRA então o espírito tranquilo a paz virá O::::: A por favor né? (( aluna A havia arrancado uma folha do caderno e estava recortando-a, mostrando desatenção com relação aquilo que estava acontecendo na aula))

Quando a professora desaprovou o comportamento da aluna, pedindo para que ela voltasse a prestar atenção na aula, primeiramente, chamou-a pelo nome, reforçando uma 
relação de proximidade entre as duas. Em seguida, utilizou a expressão por favor, para a aluna parar o que estava fazendo e concentrar-se na aula. Por fim, acrescentou também uma partícula discursiva de controle no? apelando para que A reconhecesse o seu comportamento inadequado naquele momento e mudasse de atitude. Assim, podemos perceber quantos procedimentos atenuadores estão presentes em um único ato de desaprovação com a finalidade de suavizá-lo e de evitar conflitos interacionais.

No fragmento transcrito abaixo, é possível notar, também, como a professora de italiano utilizou uma forma apelativa convencionalizada para amenizar a força ilocucionária da desaprovação e prevenir assim possíveis danos a face positiva e negativa do aluno Fo.

\section{FRAGMENTO DES-IT n $^{\circ}$}

\section{Italiano}

$C$ : quando.. è:: deve venire con uniforme?

Prof IT: ऐ̀ QUELLO CHE HA PROPRIO DOMANDATO B

Fo: IO PURE VOLEVO chiederlo

Prof IT: mi ha appena domandato la stessa cosa e gli ... gli ho detto di no

((Fo celebra))

Prof IT: MA TU AMORE LA MAGLIETTA

DELLA SCUOLA NON LA PORTI VERO ?
Tradução

$C$ : quando.. é:: tem que vir com uniforme?

Prof IT: É O QUE O B ACABOU DE PERGUNTAR

Fo: EU TAMBÉM QUERIA perguntar isso

Prof IT: ele acabou de me perguntar a mesma coisa e eu lhe... lhe disse que não

((Fo comemora $)$ )

Prof IT: MAS VOCÊ AMOR NÃO USA A CAMISETA DA ESCOLA VERDADE?

Nesse momento, como já vimos anteriormente, a turma ainda falava sobre a excursão que eles fariam com a escola, quando a aluna $\mathrm{C}$ perguntou para a professora se eles deveriam usar o uniforme no dia do passeio. Quando Fo ouviu da professora que não era necessário ir com uniforme da escola ao passeio ele comemorou vibrando.

A professora desaprovou o comportamento efusivo de Fo com a seguinte pergunta: MA TU AMORE LA MAGLIETTA DELLA SCUOLA NON LA PORTI VERO?[MAS VOCÊ AMOR NÃO USA A CAMISETA DA ESCOLA VERDADE?] Ela desaprovou a comemoração do aluno e observou que ele não usava o uniforme da escola nem mesmo para ir à escola. $\mathrm{A}$ professora suavizou a força da desaprovação também com a entonação de voz (elemento prosódico) e com a utilização da forma de tratamento afetuosa amore. Além disso, utilizou uma expressão de controle e de contato com o interlocutor vero?

Por meio dos recursos da indiretividade, da utilização de uma forma de tratamento afetuosa e de uma expressão de controle e de contato com o interlocutor, a professora 
expressou sua desaprovação de forma atenuada e cortês preservando o equilíbrio e a harmonia das trocas verbais em sala de aula.

No fragmento DES-IT no 4, também já apresentado anteriormente, foi possível notar a utilização de expressões de controle e de contato com o interlocutor como forma de atenuar um ato de desaprovação.

\section{FRAGMENTO DES-IT n ${ }^{\circ} 4$}

Italiano

M: quindi deve andare a scuola e a imparare a leggere e... a scrivere e... a studiare

Prof IT: VA BENE F ? un bambino deve avere l'opportunità di andare a scuola per imparare a leGGEre a sCRIvere vero?

$F$ : sì

Prof IT: ah::... sì e deve approfiTTAre l'opportunità approfittarsi dell'opportunità
Tradução

$M$ : então devi ir à escola e aprender a ler e... a escrever e.... estudar

Prof IT: CERTO F? uma criança deve ter a oportunidade de ir à escola para aprender a LER e a esCREver certo?

$F: \operatorname{sim}$

Prof IT: ah::... sim e deve aproVEItar a oportunidade

Nesse fragmento, como vimos quando analisamos a indiretividade, a professora expressou desaprovação de forma indireta em relação ao comportamento do aluno $\mathrm{F}$, que mostrava-se distraído e desinteressado na aula. Ela usou um trecho do texto que a aluna $\mathrm{M}$ havia acabado de ler e o transformou em pergunta para o aluno. Com esse procedimento, como já vimos, ela suavizou a força ilocucionária do ato de desaprovar. Além disso, a professora utilizou, ao final da sua pergunta, um vero? Que é uma expressão de controle e de contato com o interlocutor que minimiza a possibilidade de desacordo evitando assim tensões nas interações verbais.

Observamos essa mesma tática também em um ato de desaprovação extraído da aula em língua portuguesa, como pode ser observado abaixo:

\section{FRAGMENTO DES-PT n ${ }^{0} 1$}

Prof PORT: R ele ESTÁ conectado à base do seu telefone... você chega em casa hoje e vai olhar $R$ : sim não tem cabo posso ir até meu quarto

Fo: é esse aqui:: ( (faz um gesto com a mão indicando o tamanho do aparelho, mas $R$ não pode ver porque Fo está sentado atrás dele))

Prof PORT: você leva uma PARTE dele R

$R$ : não entendi ainda

Prof PORT: você CARREGA na sua casa uma PARTE DELE a outra parte você tem que por pra carregar numa base... não tem?

$R: \operatorname{sim}$ 
Prof PORT: aquilo está CONECTADO a um ca:bo este cabo que faz a ligaÇÃO pra você poder se comunicar

(Fo fala algo baixinho e $R$ começa a rir)

Prof PORT: tudo bem? por que que você tá rindo?

$R$ : não sei

$(R$ continua rindo)

Prof PORT: tá tudo bem?... ãhn:: não tô entendendo porque você tá rindo

$R$ : eu começo a rir às vezes

Prof PORT: estranho isso né?... sem motivo

Esse trecho também já foi visto anteriormente, quando analisamos o recurso atenuador da indiretividade na desaprovação. É o momento em que, ao término da explicação da professora, o aluno $\mathrm{R}$ começa a rir porque o aluno Fo sussurrou algo. A professora, sem entender o que estava acontecendo, desaprova o comportamento inadequado de $\mathrm{R}$ com a seguinte pergunta estranho isso né?... sem motivo. Evidenciamos a presença dessa expressão de controle e contato com o interlocutor, a qual previne um conflito entre os interlocutores com o pedido final de confirmação de acordo. Dessa forma, a desaprovação da professora se realiza de forma atenuada e cortês, diminuindo os riscos de ameça às faces positiva e negativa do aluno $\mathrm{R}$.

\subsubsection{Formas de tratamento e formas apelativas convencionalizadas}

Outro recurso utilizado para atenuar atos de desaprovação em língua portuguesa e em língua italiana foram as formas de tratamento e as formas apelativas convencionalizadas. As formas de tratamento são os pronomes pessoais, nomes próprios e as formas apelativas convencionalizadas, como as expressões olha, amor, filha, meu anjo etc.

O exemplo encontrado em nosso corpus de língua italiana é o seguinte:

\section{FRAGMENTO DES-IT n ${ }^{\circ} 7$}

Italiano

$C$ : quando.. è:: deve venire con uniforme?

Prof IT: É QUELLO CHE HA PROPRIO DOMANDATO B

Fo: IO PURE VOLEVO chiederlo

Prof IT: mi ha appena domandato la stessa cosa e gli ... gli ho detto di no

((Fo celebra $)$ )

Prof IT: MA TU AMORE LA MAGLIETTA DELLA SCUOLA NON LA PORTI VERO ?
Tradução

$C$ : quando.. é:: tem que vir com uniforme?

Prof IT: É O QUE O B ACABOU DE PERGUNTAR

Fo: EU TAMBÉM QUERIA perguntar isso

Prof IT: ele acabou de me perguntar a mesma coisa e eu lhe... lhe disse que não

((Fo comemora $)$ )

Prof IT: MAS VOCÊ AMOR NÃO USA A CAMISETA DA ESCOLA VERDADE? 
Como visto anteriormente, dentre as táticas atenuadoras empregadas pela professora para suavizar a desaprovação nesse trecho da aula, está a indiretividade e o uso de uma forma apelativa afetuosa AMORE. O uso dessa tática favorece uma aproximação entre os falantes e diminui o risco de ameaça as faces positiva e negativa do aluno, que poderia se sentir descriminado e cobrado com o fato de a professora afirmar que ele não usa o uniforme quando deveria usar.

Em português, encontramos um ato de desaprovação atenuado através da utilização do pronome de tratamento gente, como podemos observar no exemplo abaixo:

\section{FRAGMENTO DES-PT $n^{\circ} 4$}

Prof PORT: e o Bolacha?

((Alguns alunos começam a falar ao mesmo tempo))

Prof PORT: PERAÍ gente um de cada vez... fala

Podemos notar que, na desaprovação, expressa pela professora, em relação ao comportamento dos alunos que falavam todos ao mesmo tempo, está presente uma forma apelativa usada para atenuar a força do ato ilocucionário que é gente, uma forma de tratamento, que acaba generalizando a desaprovação e estendendo o pedido de silêncio para todos os alunos da classe. Dessa forma, a professora evita desaprovar de forma direta os alunos que estavam realmente conversando e prefere estender a desaprovação a todos. Como a professora faz a desaprovação de maneira atenuada e cortês além de conseguir o resultado desejado, o silêncio por parte dos alunos, ela também mantém a harmonia das trocas verbais. Valorizando a participação dos alunos, querendo ouvi-los quando eles querem falar, ela favorece e motiva o engajamento deles nas atividades desenvolvidas em sala de aula.

Outro exemplo do uso do pronome de tratamento gente para suavizar uma desaprovação pode ser observado no fragmento transcrito abaixo.

\section{FRAGMENTO DES-PT n ${ }^{\circ} 5$}

$R a$ : eu VIVO sem celular de boa

$L$ : eu não vivo sem TABLET

((alguns alunos estão falando ao mesmo tempo-barulho))

$R$ : TÁ mas se não tinha celular lá como é que fizeram aquela máquina de tecido?

Prof PORT: peraí [gente

Fo: eu não VIVO sem PSP [sem telefone

$F$ : é:: eu também não vivo sem PSP

Prof PORT: gente pera só um pouquinho o R fez uma pergunta FAla

$R$ : ãh se não tinha celular... ãh:: como é que então tinha aquela fábrica de tecido 
Nesse momento da aula, os alunos falavam sobre suas dependências em relação às novas tecnologias. A aluna Ra dizia que o celular não era imprescindível para ela, já o aluno L afirmava que ele não poderia viver sem o tablet. Nesse instante, o aluno R interrompe para manifestar uma dúvida em relação a narrativa do livro e a professora não consegue ouví-lo porque as crianças estão falando, então ela diz gente pera só um pouquinho o $R$ fez uma pergunta. Podemos observar, além da presença de uma forma apelativa (gente), a professora faz uso também de um modificador morfológico interno, o diminutivo, presente na palavra pouquinho. A utilização desses recursos enfraquece a força ilocucionária da desaprovação e minimiza os riscos de conflitos interacionais, previnindo possíveis danos a imagem dos alunos.

\subsubsection{Modificadores externos: quantificadores minimizadores}

Outros recursos atenuadores observados nos atos de desaprovação produzidos em língua portuguesa e italiana foi a utilização de modificadores externos: quantificadores minimizadores. $\mathrm{O}$ fragmento que acabamos de ver é um exemplo desse uso.

\section{FRAGMENTO DES-PT n 5}

$R a$ : eu VIVO sem celular de boa

$L$ : eu não vivo sem TABLET

((alguns alunos estão falando ao mesmo tempo-barulho))

$R$ : TÁ mas se não tinha celular lá como é que fizeram aquela máquina de tecido?

Prof PORT: peraí [gente

Fo: eu não VIVO sem PSP [sem telefone

$$
F \text { : é:: eu também não vivo sem PSP }
$$

Prof PORT: gente pera só um pouquinho o R fez uma pergunta FAla

$R$ : ãh se não tinha celular... ãh:: como é que então tinha aquela fábrica de tecido

A utilização do sufixo inho, modificador externo, minimiza a palavra pouco. Dessa forma, o que já era pouco em quantidade ficou ainda menor com a expressão um pouquinho. Assim, a professora, além dos recursos que já enumeramos anteriormente, minimizou, mais uma vez, a força ilocucionária da desaprovação, reduzindo a quantidade de tempo que ela gostaria que os alunos fizessem silêncio para ela poder ouvir a dúvida do aluno R. Em outras palavras, a professora não queria interromper a discussão, mas precisava de alguns segundos de silêncio para conseguir ouvir e tentar solucionar a dúvida do aluno R. Portanto, a professora evidenciou, mais uma vez, a importância da utilização da atenuação e da cortesia 
em sala de aula, pois, além de alcançar o efeito desejado contribuem para o bom relacionamento entre professora e alunos.

$\mathrm{Na}$ aula de Italiano, observamos uma situação parecida. A professora desaprovou de forma atenuada o comportamento dos alunos B, L e C que estavam conversando em voz alta através da utilização de um modificador externo minimizador, representado pela palavra attimo, que faz referência também à quantidade pequena de tempo de silêncio que a professora precisava para ouvir a dúvida de uma aluna.

\section{FRAGMENTO DES-IT n 8}

\section{Italiano}

$L:$ MAESTRA io stato il primo a:: consegnare Prof IT: OK...F

F: sim eu coloquei lá ((e fa un gesto con la mano))

Prof IT: Ok

((Ra alza la mano $))$

Prof IT: Ra

((B, L e C stanno chiacchierando ad alta voce $))$

Prof IT: ASPETTA B DEVO SENTIRE RA.... B aspetta un attimo

Ra: che ora che deve arrivare?
Tradução

$L$ : PROFESSORA eu fui o primeiro a:: entregar Prof IT: OK...F

$F$ : sim eu coloquei lá ((e faz um gesto com a mão))

Prof IT: Ok

((Ra levanta a mão))

Prof IT: Ra

((B, L e C estão conversando em voz alta $))$

Prof IT: ESPERA B TENHO QUE OUVIR

RA.... B espera um pouquinho

$R a$ : que horas tem que chegar?

Podemos perceber que os alunos também interagiam com a professora, mas que três deles estavam conversando entre si em voz alta, impossibilitando a professora de ouvir a dúvida da aluna Ra. Ao contrário da professora de português que escolheu generalizar a desaprovação utilizando a palavra gente, a professora de italiano escolheu um aluno em particular que estava conversando e disse a ele ASPETTA B DEVO SENTIRE RA... B aspetta un attimo. Dessa forma, a professora desaprovou o comportamento de B, suavizando a desaprovação por meio de um modificador externo minimizador, o qual produz o efeito de reparação, criando a falsa ilusão de que, depois, o aluno poderia voltar a fazer aquilo que estava fazendo antes de ser interrompido.

\subsubsection{Ausência de atenuação}

Encontramos também em nosso corpus de língua portuguesa e de língua italiana discordâncias expressas de forma direta sem o uso de atenuação. Observamos que, muitas vezes, o recurso prosódico foi usado para intensificar a desaprovação. 
A ausência de atenuação pode ocorrer, como já mencionado anteriormente, quando o interlocutor coloca seu objetivo na comunicação, isto é, quando a necessidade de comunicar torna-se urgente. Assim, o falante procurará respeitar o princípio de cooperação e as máximas conversacionais de Grice, principalmente, as de quantidade e de modo, ou seja, tentará proporcionar ao ouvinte a quantidade de informação requerida pelo objetivo da interação e, ao mesmo tempo, tentará ser claro, objetivo e sintético.

O único exemplo encontrado na aula de português ocorreu em um ato de desaprovação realizado entre os alunos. O próximo fragmento retrata o momento da aula em que o aluno $G$ foi até a professora para dizer que ele já havia terminado o exercício no caderno. Então a professora disse que o exercício deveria ser entregue a ela, assim o aluno foi até o fundo da sala para buscar o seu caderno. Enquanto isso, a professora começou a aula perguntando para a classe em que capítulo do livro haviam parado a leitura.

Nesse momento, os alunos C e L perceberam que o aluno $\mathrm{G}$ estava em pé no fundo da sala e julgaram inadequado tal comportamento, pois os demais alunos já estavam sentados e com o livro de leitura na mão. Então, a aluna $C$ olhou para $G$ e lhe disse $G$ vai ler. Em seguida, outro colega de classe, o aluno L, disse para o aluno G, $G$ senta. A aluna C ainda acrescentou: quando for para você pegar seu caderno você pega. Eles não haviam notado que o aluno G queria pegar seu caderno para mostrá-lo à professora. $\mathrm{G}$ obedeceu seus colegas e voltou para o seu lugar sem o caderno, como pode ser observado abaixo:

\section{FRAGMENTO DES-PT n ${ }^{\circ} 6$}

$G$ : Prof PORT éh::... eu terminei a::.. a prova

Prof PORT: oi?

$G$ : no caderno

(( a professora fica olhando para $G$ como se esperasse ele acrescentar outras informações. Como ele fica em silêncio, a professora abre as mãos, continua olhando para ele e diz ))

Prof PORT: você tem que me entregar

(( $G$ faz um sinal afirmativo com a cabeça e vai até o fundo da sala para pegar seu caderno))

Prof PORT: vamos lá gente? ontem a gente parou no capítulo

$F$ : vinte e sete?

$C$ : G vai ler ((frase exclamativa))

L: G senta ((frase exclamativa))

$C$ : quando for para você pegar seu caderno você pega

Prof PORT: PAgina cento e três

(( $G$ volta para o seu lugar sem caderno $))$

As desaprovações expressas pelos alunos $\mathrm{C}$ e $\mathrm{L}$ em relação ao comportamento de $\mathrm{G}$, ao fato dele estar em pé, enquanto todos na sala estavam sentados, é expressa de forma direta 
e sem a utilização de nenhuma tática atenuadora, podendo ser entendidas como ordens $\boldsymbol{G}$ vai ler / G senta / quando for para você pegar seu caderno você pega. Entendemos a falta de atenuação nesse contexto não como descortesia por parte dos alunos, mas relacionada à urgência comunicativa que a situação exigia, uma vez que a aula já havia começado e G era o único aluno que ainda estava em pé naquele momento.

A seguir, descreveremos os exemplos da aula de italiano em que não identificamos a utilização de atenuação. O primeiro fragmento refere-se a um momento da aula em que a professora percebe que um aluno estava distraído e o desaprova.

\section{FRAGMENTO DES-IT n 9}

\section{Italiano}

Prof IT: Esattamente i bambini parlano e vogliono essere sentiti DA CHI?

$M$ : Dalle altre persone

Prof IT: dalle altre persone perfetto...R ATTENZIONE

( $R$ era distratto, rivolto verso il lato e prontamente obedisce la professoressa)
Tradução

Prof IT: Exatamente as crianças falam e querem ser ouvidas POR QUEM ?

$M$ : pelas outras pessoas

Prof IT: por outras pessoas perfeito...R ATENÇÃO

$(R$ estava distraído virado para o lado, imediatamente obedece a professora)

Podemos notar que a desaprovação da professora foi expressa de maneira direta e sem a utilização de atenuadores. A entonação da voz e o nome do aluno são usados para intensificar a ordem dada a ele, isto é, prestar atenção na aula.

Mais adiante, durante a discussão sobre os direitos das crianças gerada pela leitura dos textos, a aluna $\mathrm{M}$ comentou que tinha um livro sobre cidadania e que nele estava escrito que os pais deveriam ensinar seus filhos, desde o nascimento, a usarem armas. Então a professora pediu aos alunos que pensassem na sociedade espartana e perguntou quando as crianças começavam a ser preparadas para a guerra. Nesse momento, o aluno $\mathrm{S}$ disse que as crianças atiravam em todo mundo e começou a encenar, fingindo que estava segurando uma arma e imitando o barulho dos tiros com a boca. A professora, imediatamente, desaprovou-o com o olhar e com uma ordem, como pode ser observado no fragmento abaixo.

\section{FRAGMENTO DES-IT nº 10}

\section{Italiano}

$M$ : maestra io l'anno scorso avevo un libro di cittadinanza che praticamente c'era una pagina in cui:: un genitore quando... è nato un figlio
Tradução

$M$ : professora eu o ano passado tinha um livro de cidadania que praticamente tinha uma página na qual:: um dos pais quando... nascia um filho 
imparava fin da quando è nato a fare a usare le armi

Prof IT: è::: penSAte com'era la società spartana?

$F$ : veLOce militare

Prof IT: QUANDO I BAMBINI COMINCIAVANO a allenarsi addestrasi preparasi per la guerra?

$S$ : SPARAVA A TUTTI

((lui fa un gesto come se stesse in possesso di una pistola e fa il rumore dei colpi con la bocca. L'insegnante getta uno sguardo di disapprovazione verso lui e lui tace))

$R a: 14$ anni

Prof IT: QUANDO?

Ra: 14 anni

Prof IT: 14 anni però anche PRIMA la società sparTAna separava già il bambino per sopportare il freddo tutte quelle condizioni difficili no? S MENO aprendia desde quando nasce a fazer a usar armas Prof IT: é::: peNSEm como era a sociedade espartana?

$F$ : ráPIda militar

Prof IT: QUANDO AS CRIANÇAS COMEÇAVAM a serem treinadas a se prepararem para a guerra?

$S$ : ATIRAVA EM TODO MUNDO

((faz um gesto como se estivesse segurando uma arma e faz o barulho dos tiros com a boca. A professora lança um olhar de desaprovação para ele e faz silêncio.))

$R a: 14$ anos

Prof IT: QUANDO?

$R a: 14$ anos

Prof IT: 14 anos mas até mesmo ANTES a sociedade esparTAna já separava uma criança para suportar o frio todas aquelas condições dificeis né? S MENOS

A professora como regente de uma interação assimétrica tem o poder máximo para decidir se um comportamento está dentro das regras da interação em andamento ou se é uma insobordinação (ORLETTI, 2014). Assim, nos atos de desaprovação, é a professora que decide se o comportamento dos alunos está ou não adequado. No trecho que acabamos de ver, notamos que a professora julga o comportamento do aluno como incorreto e, antes de manifestar verbalmente a desaprovação, manifesta-a com o olhar em direção ao aluno, isto é, faz uso também de um recurso paralinguístico que, nesse caso, ao invés de atenuar a desaprovação, reforça-a. A ausência de atenuação nesse caso não está relacionada com a imediatez da comunicação, pois a professora teve tempo para pensar como desaprovar o aluno quando deixou a interação prosseguir, pois a desaprovação só foi realizada alguns turnos depois. Intuimos, então, que a falta de atenuação expressa o descontentamento da professora e reforça sua posição de autoridade em sala de aula.

No último fragmento, observamos como a professora de italiano desaprovou o comportamento do aluno F por meio da entonação de voz utilizada para chamar o seu nome.

\section{FRAGMENTO DES-IT nº11}

\section{Italiano}

Prof IT: per andare a scuola non ci sono le strade non c'è un modo no? una via di comunicazione lì che li possa o::::: $\mathbf{F}$ ( $F$ era rivolto all'indietro $e$ chiacchierava con $L)$ )
Tradução

Prof IT: para ir à escola não existem estradas não tem um modo né? um meio de comunicação ali que os possa o::::: $\mathbf{F}((F$ estava virado para trás e conversava com $L)$ ) 
De acordo com Armengaud (2006), as pessoas durante uma conversa, em geral, respeitam as máximas conversacionais identificadas por Grice (1975), mas, quando um falante as infringe, o interlocutor é levado a preeencher o não dito com uma implicatura para restabelecer o sentido da comunicação. A implicatura conversacional, segundo a autora, é "a hipótese pela qual se restabelece a harmonia no mundo da fala cooperativa. A aptidão do ouvinte em forjar tal hipótese é justamente sua aptidão a receber a informação implícita que o falante não quer dar explicitamente. É a habilidade de entender o subentendido 9 ." (ARMENGAUD, 2006, p. 91).

Assim, por meio da entonação de voz utilizada pela professora, do fato de o aluno $\mathrm{F}$ estar sentado com o corpo virado para trás e conversando com seu colega L no momento em que a professora estava falando, fez com que ele, ao ouvir seu nome, entendesse prontamente que se tratava de uma desaprovação do seu comportamento. Assim, virou-se imediatamente para a frente, voltando a prestar atenção na aula.

Para finalizar, apresentamos, abaixo, um quadro com todas as táticas atenuadoras utilizadas nos atos de discordância e desaprovação, realizados em italiano e português brasileiro, pelas crianças bilíngues, participantes de nossa pesquisa, e por suas respectivas professoras, durante a interação em sala de aula.

\begin{tabular}{|l|c|c|c|c|}
\hline \multicolumn{1}{|c|}{$\begin{array}{c}\text { Procedimentos } \\
\text { atenuadores }\end{array}$} & $\begin{array}{c}\text { Discordância } \\
\text { IT }\end{array}$ & $\begin{array}{c}\text { Discordância } \\
\text { PT }\end{array}$ & $\begin{array}{c}\text { Desaprovação } \\
\text { IT }\end{array}$ & $\begin{array}{c}\text { Desaprovação } \\
\text { PT }\end{array}$ \\
\hline $\begin{array}{l}\text { I. Modificadores morfológicos } \\
\text { internos: diminutivos }\end{array}$ & --- & --- & --- & $\mathrm{X}$ \\
\hline II. Modificadores externos & $\mathrm{X}$ & --- & $\mathrm{X}$ & $\mathrm{X}$ \\
\hline $\begin{array}{l}\text { III. Termos ou expressões mais } \\
\text { suaves para expressar um } \\
\text { conteúdo desagradável }\end{array}$ & --- & --- & --- \\
\hline $\begin{array}{l}\text { IV. Emprego de palavras } \\
\text { estrangeiras }\end{array}$ & --- & --- & --- & -- \\
\hline $\begin{array}{l}\text { V. Usos modalizados dos tempo } \\
\text { verbais }\end{array}$ & --- & $\mathrm{X}$ & --- & - \\
\hline $\begin{array}{l}\text { VI. Verbos, construções verbais } \\
\text { e partículas discursivas com } \\
\text { valor modal que expressam }\end{array}$ & $\mathrm{X}$ & -- & -- & \\
\hline
\end{tabular}

\footnotetext{
${ }^{9}$ Grifo da autora.
} 


\begin{tabular}{|c|c|c|c|c|}
\hline $\begin{array}{l}\text { opinião em forma de dúvida ou } \\
\text { de probabilidade }\end{array}$ & & & & \\
\hline $\begin{array}{l}\text { VII. Verbos, construções } \\
\text { verbais e partículas discursivas } \\
\text { que expressam fingimento de } \\
\text { incerteza, de incompetência ou } \\
\text { de ignorância }\end{array}$ & --- & --- & --- & --- \\
\hline $\begin{array}{l}\text { VIII. Construções que } \\
\text { limitam/restringem a opinião da } \\
\text { própria pessoa ou de um } \\
\text { determinado âmbito }\end{array}$ & --- & $\mathrm{X}$ & --- & --- \\
\hline $\begin{array}{l}\text { IX. Pedidos, perguntas e ordens } \\
\text { expressas de forma indireta. } \\
\text { Com formulação afirmativa ou } \\
\text { negativa com ou sem a fórmula } \\
\text { "por favor" }\end{array}$ & --- & --- & $\mathrm{X}$ & $\mathrm{X}$ \\
\hline $\begin{array}{l}\text { X. Expressões de desculpa } \\
\text { perante uma interrupção, uma } \\
\text { pergunta, um favor ou perante } \\
\text { uma expressão de uma opinião }\end{array}$ & --- & --- & --- & --- \\
\hline $\begin{array}{l}\text { XI. Estruturas sintáticas } \\
\text { condicionais, concessivas ou } \\
\text { temporais que modificam ou } \\
\text { restringem o ato de fala }\end{array}$ & $\mathrm{X}$ & --- & --- & --- \\
\hline $\begin{array}{l}\text { XII. Partículas e construções } \\
\text { justificadoras do dizer ou } \\
\text { justificações de desculpas }\end{array}$ & --- & $\mathrm{X}$ & --- & --- \\
\hline $\begin{array}{l}\text { XIII. Elipses de conclusão, } \\
\text { estruturas suspensas }\end{array}$ & --- & --- & $\mathrm{X}$ & --- \\
\hline XIV. Impessoalização I & --- & --- & $\mathrm{X}$ & --- \\
\hline XV. Impessoalização (II) & $\mathrm{X}$ & --- & --- & --- \\
\hline $\begin{array}{l}\text { XVI. Movimento de } \\
\text { reformulação }\end{array}$ & --- & --- & --- & --- \\
\hline XVII. Concessividade & $\mathrm{X}$ & $\mathrm{X}$ & --- & --- \\
\hline $\begin{array}{l}\text { XVIII. Marcadores discursivos } \\
\text { modais de objetivação }\end{array}$ & --- & $\mathrm{X}$ & --- & --- \\
\hline $\begin{array}{l}\text { XIX. Partículas discursivas, } \\
\text { expressões de controle e de } \\
\text { contato com o interlocutor }\end{array}$ & $\mathrm{X}$ & $\mathrm{X}$ & $\mathrm{X}$ & $\mathrm{X}$ \\
\hline $\begin{array}{l}\text { XX. Formas de tratamento e } \\
\text { formas apelativas } \\
\text { convencionalizadas }\end{array}$ & $\mathrm{X}$ & $\mathrm{X}$ & $\mathrm{X}$ & $\mathrm{X}$ \\
\hline
\end{tabular}




\begin{tabular}{|l|c|c|c|c|}
\hline $\begin{array}{l}\text { XXI. Emprego de elementos } \\
\text { prosódicos, paralinguísticos e } \\
\text { gestuais }\end{array}$ & --- & X & -- & -- \\
\hline XXII. Outros & --- & -- & -- & --- \\
\hline
\end{tabular}

Quadro 8 - Táticas atenuadoras utilizadas nos atos de discordância e desaprovação por crianças bilíngues, falantes de italiano e português brasileiro e suas professoras, durante a interação em sala de aula

Na sequência, apresentaremos as considerações finais. 


\section{CONSIDERAÇÕES FINAIS}

O objetivo desta pesquisa foi investigar como as relações pessoais se constroem por meio da linguagem em sala de aula. Tendo como base a Pragmática e a Cortesia Verbal, focalizamos a (não) utilização de atenuação em dois tipos de atos de fala: discordância e desaprovação e analisamos seus efeitos nas relações pessoais em sala de aula composta por crianças falantes bilíngues de italiano e português brasileiro e suas respectivas professoras.

Retomando nossas primeiras duas perguntas de pesquisa: (i) Quais são os componentes pragmáticos do italiano e do português brasileiro relacionados à cortesia verbal e, mais especificamente, ao uso de estratégias atenuadoras nos atos de fala discordância e desaprovação em sala de aula e; (ii) Em que medida é possível identificar a utilização de estratégias atenuadoras na produção desses atos de fala por crianças bilíngues, italianoportuguês brasileiro, durante a interação em sala de aula e quais são os efeitos da sua (não) utilização, percebemos, a partir da análise dos atos de discordância realizados em língua portuguesa, que a maioria deles (com exceção de um apenas) apresentava atenuação, isto é, em cada ato de discordância existia a presença de pelo menos uma tática atenuadora que minimizava a força do ato ilocucionário. Notamos que a utilização de procedimentos atenuadores nos atos de discordância objetivava a prevenção de conflitos interacionais e nas relações pessoais, logo a atenuação relacionava-se à cortesia verbal em sala de aula. Já nos atos de discordância realizados em língua italiana, encontramos um menor número de casos de atenuação. Verificamos nesses atos que o uso de procedimentos atenuadores objetivava, além da prevenção, também a reparação da ameaça à imagem do interlocutor e, algumas vezes, exercia a função de autoproteger o falante. Desse modo, a atenuação nem sempre estava relacionada à cortesia verbal, entendida como um conjunto de normas que rege o comportamento dos indivíduos durante uma troca comunicativa verbal. A maior ausência de atenuadores nos atos de discordância em língua italiana pode estar relacionada a uma tendência natural da língua italiana em realizar as discordâncias de forma imediata e direta, talvez acentuada pela própria assimetria da sala de aula.

Já nos atos de desaprovação, que ocorreram, principalmente, na interação entre professor-aluno(s), encontramos somente dois exemplos em que a desaprovação ocorreu na interação aluno(s)-aluno(s) em sala de aula; observamos tanto a presença de estratégias atenuadoras quanto a ausência delas nos atos realizados em ambas as línguas. A presença de táticas atenuadoras relacionava-se à cortesia verbal, já que o intrinsic FTA da desaprovação 
era suavizado, tentando evitar conflito na relação. Assim, observou-se que, quando a desaprovação era feita de forma atenuada e realizada por meio de perguntas, podia ser confundida com um pedido, já quando era expressa sem o uso de atenuadores assemelhava-se a uma ordem.

Com relação à nossa terceira e última pergunta de pesquisa: (iii) em que medida é possível identificar analogias e diferenças na utilização dos procedimentos atenuadores em italiano e português? Notamos que, em língua portuguesa, as táticas mais utilizadas pelos falantes para minimizar a força ilocucionária do ato de discordar foram: a concessividade; o uso de partículas discursivas, expressões de controle e de contato com o interlocutor e uso modalizado dos tempos verbais. Em língua italiana, notamos um número inferior de ocorrências de atenuação nesses atos.

Nos atos de discordância, notamos a presença de algumas táticas atenuadoras somente nos atos em português e de outras táticas somente nos atos de discordância realizados em língua italiana. Os procedimentos atenuadores encontrados somente em português foram: a modalização dos tempos verbais, a presença de marcadores discursivos modais de objetivação, elementos prosódicos, construções que limitam/restringem a opinião da própria pessoa ou de um determinado âmbito, construções justificadoras do dizer ou justificações de desculpas, utilizados para mitigar a força da discordância. Já os procedimentos atenuadores encontrados somente nos atos de discordância em língua italiana foram: verbos, construções verbais e partículas discursivas com valor modal que expressam opinião em forma de dúvida ou de probabilidade; modificadores externos como difusores significativos e estruturas sintáticas condicionais, concessivas ou temporais que modificam ou restringem o ato de fala.

Nos atos de desaprovação, as estratégias atenuadoras mais utilizadas em língua portuguesa pelos falantes, para minimizar o ato de desaprovar foram: a indiretividade e as formas apelativas convencionalizadas. Já em língua italiana, as estratégias mais utilizadas foram também a indiretividade e as partículas discursivas e expressões de controle e de contato com o interlocutor. Notamos que, em ambas as línguas, esses atos também foram realizados sem atenuação.

Nesse sentido, podemos dizer que os atos de discordância em língua portuguesa privilegiaram a relação entre os interlocutores por meio da cortesia verbal e as discordâncias em língua italiana privilegiaram o caráter imediato da comunicação, evitando, algumas vezes, a utilização de atenuadores. Já os atos de desaprovação se realizaram de maneira muito semelhante em ambas as línguas, apresentando ou não procedimentos atenuadores. A 
presença de táticas atenuadoras relacionava-se à cortesia verbal, evidenciando a preocupação em evitar conflitos na relação verbal e pessoal em sala de aula. A ausência de atenuação reforçava a força do ato ilocucionário de desaprovar, evidenciando um maior grau de imposição do falante em relação ao interlocutor.

A pesquisa, de cunho qualitativo, nos permitiu entrar em contato com uma realidade determinada e com características definidas. A escolha do contexto foi determinante para adentrarmos a sala de aula de uma escola ítalo-brasileira localizada no Brasil, descobrindo algumas de suas peculiaridades. Além disso, por meio de gravações em áudio e vídeo e das observações realizadas, pudemos analisar as interações dos mesmos alunos em duas línguas diferentes - italiano e português brasileiro -, buscando entender como esses indivíduos construíam juntos o sentido para o agir comunicativo e observando, a partir de uma perspectiva pragmática, como se manifestava a atenuação nos atos de fala da discordância e da desaprovação.

Sabemos que os dados analisados são limitados e, que para a confirmação ou não das hipóteses levantadas com nossa pesquisa, seria necessário a realização de novas pesquisas com um maior número de participantes e com mais horas de gravação dentro desse mesmo contexto. Além disso, a observação mais prolongada e individual de cada criança também poderia contribuir para verificar se os mesmos alunos podem apresentar comportamentos linguísticos parecidos ou diferentes nas duas línguas, isto é, analisar de que forma cada criança individualmente, realiza os mesmos atos de fala em Português brasileiro e em Italiano. Na nossa pesquisa, a diferente participação dos alunos nas duas aulas, ora participando de forma mais ativa na aula de Português e menos na de Italiano, ora fazendo o contrário, impediu que uma análise desse tipo pudesse ter sido levada a cabo. Não foi possível, de fato, observar o mesmo aluno produzindo, por exemplo, discordâncias em ambas as línguas.

Uma questão que não foi abordada em nossa pesquisa, mas que seria igualmente interessante investigar é de que maneira o Italiano e o Português brasileiro são ensinados nesse contexto específico, pois, como vimos, existe uma multiplicidade de elementos que interagem constituindo e caracterizando o contexto da escola e os alunos que a frequentam. Assim, as questões de ensino e aprendizagem de língua materna, segunda língua e língua estrangeira, bem como o ensino explícito ou implícito das componentes pragmáticas mereceriam ainda ser exploradas.

Outro aspecto que pode ser ainda investigado em futuras pesquisas é de que forma em uma escola na qual duas línguas são utilizadas nas atividades, o bilinguismo se manifesta 
em cada criança, isto é, como cada falante desenvolve sua capacidade comunicativa em dois idiomas que convivem diariamente e precisam ser desenvolvidos em todos os níveis de comunicação.

Para finalizar, acreditamos que os resultados desta pesquisa salientam a importância dos estudos pragmáticos para entender como os sujeitos se constroem e constroem suas relações pessoais por meio da linguagem. Nesse sentido, os estudos sobre cortesia verbal tornam-se relevantes porque ela é um princípio fundamental de equilíbrio que rege as relações entre os interlocutores durante uma troca verbal e, como a cortesia se configura de modo diferente em cada sociedade, o modo de se relacionar varia culturalmente. Logo, conhecer e entender essas diferenças permite evitar conflitos nas relações pessoais durante a interação. 


\section{REFERÊNCIAS}

ALBELDA, M. (2010) ¿Cómo se reconoce la atenuación? Una aproximación metodológica basada en el español peninsular hablado. In ORLETTI, F.; MARIOTTINI, L. (Eds.). (Des)cortesía en español. Espacios teóricos y metodológicos para su estudio. RomaEstocolmo: Università degli Studi Roma Tre; EDICE, p. 47-70.

ALBELDA, M., CESTERO, A. (2011) De nuevo, sobre los procedimientos de atenuación lingüística. Español Actual 96, p.121-155.

ALBELDA, M. et all (2014) Ficha metodológica para el análisi pragmático de la atenuación en corpus discursivos del español. ES.POR. ATENUACIÓN. Oralia17, p 7-62.

ARMENGAUD, F. (2006) A Pragmática. Tradução de Marcos Marcionilo. São Paulo: Parábola Editorial.

AUSTIN, J. (1990 [1962]) Quando dizer é fazer: palavras em ação. Tradução Danilo Marcondes de Souza Filho. Porto Alegre: Artes Médicas.

BAKHTIN, M. (2002) Marxismo e filosofia da linguagem: problemas fundamentais do método sociológico na ciência da linguagem. Tradução de Michel Lahud e Yara Frateschi Vieira. São Paulo: Hucitec Annablume.

BLUM-KULKA, S. (1992) The metapragmatics of politeness in Israeli Society. In R. Watts, S. Ide, K. Ehlich (eds), Politeness in language: studies in Its history, theory and practice, Berlin: Mounton de Gruyter, p. 255-281.

BORGES NETO, J. (2014) De que trata a pragmática? In: Coletânea do I Workshop Internacional de Pragmática, GODOY,E. (org). Curitiba: UFPR, p. 13-21.

BRAVO, D. (2005) Estudios de la (des) cortesia en español. Buenos Aires: Dunken. 
BRIZ, A. (1995) La atenuación en la conversación coloquial. Una categoria pragmática. In: CORTÉS, L. (ed.). El español coloquial: actas del I Simposio sobre análisis del discurso oral. Almeria: Universidad de Almeria, Servicio de Publicaciones, p. 103-122.

(1998) El español coloquial. Esbozo di pragmagramática. Barcelona: Ariel.

(2003) La estrategia atenuadora en la conversación cotidiana española. In:

BRAVO, D. (ed.), p. 17-46.

(2004) Cortesía verbal codificada y cortesía verbal interpretada en la conversación. In: BRAVO, D., BRIZ, A. (eds.), p. 67-93.

(2013) Atenuadores: estratégias e táticas. Versão Luis A. da Silva, Adriane M.

de Andrade, Ramiro Caggiano Blanco. In: Revista Linha d'Água, n²6, p. 281-314. Disponível em: <http://www.revistas.usp.br/linhadagua/article/viewFile/64415/71564\%3E>. Acesso em: 29/09/2016.

BRIZ, A.; ALBELDA,M. (2013) Una propuesta teórica metodológica para el análisis de la atenuación lingüística en español y portugués. La base de un proyecto en comum (ES.POR.ATENUACIÓN). In: ONOMÁZEIN - Revista semestral de lingüística, filologia y traducción, p. 288-319.

BROWN, P.; LEVINSON, S. C. (1987[1978]) Politeness: Some universals in language use. Cambridge: Cambridge University Press.

BROWN, P. (2015). Politeness and Language. In: International Encyclopedia of the Social \& Behavioral Sciences, 2nd edition, Volume 18. Disponível em: <http://dx.doi.org/10.1016/B978-0-08-097086-8.53072-4>. Acesso em: 15/10/2017.

BROWN, R .; GILMAN, A. (1960). Os pronomes de poder e solidariedade. In: SEBEOK, T. A. (Ed.). Estilo em idioma. Cambridge: MIT Press, p. 253-276.

CAFFI, C. (1999) On mitigation. Journal of pragmatics, 31, p. 881-909. 
(2009) Pragmatica. Sei Lezioni. Roma: Carocci.

CESTERO, A., ALBELDA, M. (2012) La atenuación lingüística como fenómeno variabile. Oralia 15 , p. 77-124.

CONTENTO, S.; MELANI,S.; ROSSI, F. (2014) Dimensioni e tipologie di bilinguismo. In Crescere nel bilinguismo, CONTENTO, S. (a cura di), Roma: Carocci, p. 13-27.

DOMANESCHI, F. (2014). Introduzione alla pragmatica.Roma: Carocci.

ESCANDELL VIDAL, M. (1996) Introducción a la pragmática. Barcelona: Ariel.

FILMORE, C.J. (1971) Towards a theory of deixis. The PCCLLU Papers (Departamento de Lingüística, Universidade do Hawaii), 3-4, p. 219-241.

(1975) Santa Cruz Lectures on Deixis. Mimeografia, Indiana University Lingusitics Club.

FRASER, B. (1980) Conversation mitigation. In Journal of Pragmatics, IV-4, p. 341-350.

FRASER B., NOLEN W. (1981) The Association of Deference with Linguistic Form. In International Journal of the Sociology of Language, 27, p. 93-111.

FREGE, G. (1892) Über Sinn und Bedeutung. In: Zeitschrift für Philosophie und philosophische Kritik, 100, p. 25-50.

GARCEZ,A.; DUARTE,R.; EISENBERG, Z. (2011) Produção e análise de videogravações em pesquisas qualitativas. Educação e Pesquisa, São Paulo, v. 37, n.2, p. 249-262, mai-ago.

GOFFMAN, E. (2011 [1967]) Ritual de interação: ensaios sobre o comportamento face a face. Tradução de Fábio Rodrigues Ribeiro da Silva, São Paulo: Vozes. 
.(1986) Frame analysis: an essay on the organization of experience. Boston, Northeastern University Press.

. (2002) Footing. In: B. T. Ribeiro e P. M. Garcez, (orgs.), Sociolingüística interacional, 2. ed., São Paulo, Loyola.

GRICE, H. (1975) Logic and Conversation. In: COLE,P.; MORGAN, J. (eds.), Sintax and semantics 3: speech acts. New York: Academic Press, p. 41-58.

GROSJEAN, F. (1989) Neurolinguistcs, beware! The bilingual is not two monolinguals in one person. In "Brain and Language", 36, p. 3-15.

(1997) Processing mixed languages: issues, findings and models. In Tutorials in bilingualism: psycholinguistic perspectives, A. M.B. De Groot, J.F. Kroll (eds.), Lawrence Erlbaum Associates, Mahwah (NJ), p. 225-254.

HARMERS, J.; BLANC,M. (2000) Bilinguality and Bilingualism. Cambrige: Cambrige University Press.

HAVERKATE, H. (1994) La Cortesia verbal. Madrid: Gredos.

HOUAISS, A; VILLAR, M. (2004) Minidicionário Houaiss da língua portuguesa. Rio de Janeiro: Objetiva.

HONORATO, A. et al. (2006) A vídeo-gravação como registro, a devolutiva como procedimento: pensando sobre estratégias metodológicas na pesquisa com crianças. In: Reunião Anual da Associação Nacional de Pós-Graduação e Pesquisa em Educação, 29, Caxambu: ANPEd.

HYMES DELL, H. (1979) La competenza comunicativa. In: F. Ravazzoli (acura di), Universali linguistici. Milano: Feltrinelli, p. 212-43. 
KERBRAT-ORECCHIONI, C. (2006) Análise da Conversação: princípios e métodos. São Paulo: Parábola.

KOLKOVÁ, L. (2006). L'uso dei pronomi allocutivi tu,voi e Lei in italiano. Disponível em <https://is.muni.cz/th/74683/ff_b/TESI_finale.pdf>. Acesso em: 15/10/2017.

KRASHEN, S. (1981) Second language acquisition and second language learning. Oxford: Pergamon.

LAKOFF, R. (1973) The logic of politeness; or, minding your p's and q's. In Paper from the Regional Meeting, Chicago Linguistic Society, IX, p. 292-315.

LEONARDOS, A; FERRAZ, E; GONÇALVES, H (1999) O uso do vídeo em metodologia de avaliação. Lumina, Juiz de Fora, v. 2, n.1, p. 123-133, jan-junho.

LEVINSON, S. (2007) Pragmática. Trad. Luís Carlos Borges, Aníbal Mari. São Paulo: Martins Fontes.

LOIZOS, P. (2008) Vídeo, filme e fotografias como documentos de pesquisa. In: BAUER, M.; GASKELL, G. (Orgs.). Pesquisa qualitativa com texto, Imagem e som. 2.ed. Petrópolis: Vozes, p. 137-155.

LUDKE, M.; ANDRE, M. (1986) Pesquisa em educação: abordagens qualitativas, São Paulo: Editora Pedagógica e Universitária.

LYONS. J. (1968) An Introduction to Theoretical Linguistics. Cambridge: Cambridge University Press.

(1977) Semantics, vols. 1 e 2. Cambridge: Cambridge University Press.

MARCUSCHI, L. A. (2005) O diálogo no contexto da aula expositiva: continuidade, ruptura e integração. In: PRETI, Dino (Org) Diálogos na fala e na escrita. São Paulo: Humanitas. p. 45-84. 
MARIOTTINI, L. (2007) La cortesia. Roma: Carocci.

MORRIS, C. (1958 [1938]) Fundamentos de la teoria de los signos. Suplementos del seminario de problemas cientificos y filosoficos, $\mathrm{n}^{\circ} 12$, Cidad Universitaria Mexico: Universidad Nacional de Mexico. (título original: Foundations of the Theory of Signs).

ORLANDI, E. (1987) A linguagem e seu funcionamento: as formas do discurso. Campinas: Pontes.

ORLETTI, F. (2014) La conversazione desiguale. Roma: Carocci.

PALOTTI, G. (2006) La seconda lingua. Milano: Bompiani.

PIAGET, J. (1978) A formação do símbolo na criança, imitação jogo e sonho, imagem e representação. Rio de Janeiro: Zahar.

RAJAGOLAPAN, K. (2014) Pragmática: quo vadis? In: Coletânea do I Workshop Internacional de Pragmática, GODOY,E. (org). Curitiba: UFPR, p. 23-31.

RUSSELL, B. (1905) On Denoting. In Mind, 14, 56, p. 479-493.

SADALLA, A; LAROCCA, P. (2004) Autoscopia: um procedimento de pesquisa e de formação. Educação e Pesquisa, São Paulo, v. 30, n.3, p. 419-433, set-dez.

SBISÀ, M. (2002) Speech acts in context. Language \& Comunication, v.22, p. 421-436.

SEARLE, J. (2009 [1969]) Atti linguistici. Saggio di filosofia del linguaggio. Torino: Bollati Boringhieri. (título original: Speech Acts).

(1979) Expression and meaning: studies in the theory of speech acts. Cambridge: Cambridge University Press. 
SILVA DA, L. (2005) O diálogo professor/aluno na aula expositiva. In: PRETI, D. (org) Diálogos na fala e na escrita. São Paulo: Humanitas, p. 19-44.

(2008) Cortesia e formas de tratamento. In: Cortesia verbal, PRETI, D. (org). São Paulo: Humanitas, p. 157-192.

STALNAKER, R. (2002) Common Ground. In Linguistics and Philosophy, 25 (5-6), p.701721.

STRAWSON, P. (1950) On Referring. In Mind, 59, p. 320-344.

SWAIN, M. (2005) The Output Hypothesis: Theory and Research. In Handbook of Research in Second Language Teaching and Learning. London: Hinkel (eds), p.471-483.

VAN DIJK,T. (2012) Discurso e contexto: uma abordagem sociocognitiva. São Paulo: Contexto. 


\section{ANEXO A- MINUTAGEM DA AULA DE PORTUGUÊS}

\begin{tabular}{|c|c|}
\hline $\begin{array}{l}\text { Duração } \\
\text { (mm:ss) }\end{array}$ & Descrição \\
\hline $0: 00-3: 13$ & $\begin{array}{l}\text { A professora de português entra na sala de aula, conversa com os alunos (fala } \\
\text { brincando que vai jogar um deles pela janela). A aluna Ra se levanta e entrega } \\
\text { um doce para a professora e ela agradece abraçando e beijando a aluna. A } \\
\text { professora aproveita e informa a Ra que ela deve chegar às } 6 \mathrm{~h} 30 \text { para o } \\
\text { passeio e não às } 6 \mathrm{~h} \text {. A aluna C reclama que quase não havia dormido naquela } \\
\text { noite e a professora diz que também não e dá saudações alviverdes para a } \\
\text { classe (o Palmeiras havia ganhado no dia anterior) e inicia-se uma breve } \\
\text { conversa sobre isso. Em seguida, a professora diz aos alunos que gostaria de } \\
\text { terminar a leitura do livro naquela aula e pede a eles para pegarem seus livros } \\
\text { no armário. Enquanto as crianças se levantam para pegá-lo, alguns alunos } \\
\text { aproveitam para falar com a professora e outros conversam entre eles. } \\
\text { (interação) }\end{array}$ \\
\hline $3: 13-9: 53$ & $\begin{array}{l}\text { A professora, com o objetivo de retomar os últimos acontecimentos da } \\
\text { narrativa, pergunta aos alunos o que havia acontecido até aquele momento da } \\
\text { leitura. O aluno F levanta o braço e pede para contar os fatos, a professora } \\
\text { autoriza. O aluno L faz uma correção na ordem dos fatos narrados por F. } \\
\text { Demais alunos querem participar e a professora organiza a participação de } \\
\text { cada um. A interação ocorre por meio de perguntas e respostas. Em um } \\
\text { determinando momento, a professora pede aos alunos que façam hipóteses } \\
\text { sobre o prosseguimento da narrativa. (interação) }\end{array}$ \\
\hline 9:53-10:38 & $\begin{array}{l}\text { Início da leitura do livro. A professora organiza a ordem de leitura da } \\
\text { narrativa, distribuindo os trechos segundo uma ordem espacial. Desse modo, } \\
\text { cada aluno fica encarregado de ler uma parte até um ponto final, o colega que } \\
\text { está sentado atrás dele é responsável por continuar a leitura e assim, } \\
\text { sucessivamente, até o final do capítulo ou até a professora pedir para parar a } \\
\text { leitura. A aluna M começa a leitura. (leitura) }\end{array}$ \\
\hline $10: 38-12: 00$ & $\begin{array}{l}\text { A professora explica o trecho lido, chama a atenção para o fato de que são } \\
\text { duas histórias acontecendo simultaneamente, ou , nas palavras dela, dois } \\
\text { cenários distintos. (exposição) }\end{array}$ \\
\hline $12: 00-12: 27$ & Gi continua a leitura. (leitura) \\
\hline $12: 27-12: 48$ & $\begin{array}{l}\text { A professora pergunta para a classe o significado de uma palavra que acabou } \\
\text { de aparecer no texto. (interação) }\end{array}$ \\
\hline $12: 48-14: 59$ & $\begin{array}{l}\mathrm{O} \text { aluno Gi retoma a leitura. Em seguida, } \mathrm{O} \text { aluno } \mathrm{T} \text { continua a leitura. } \\
\text { (leitura) }\end{array}$ \\
\hline $14: 59-15: 25$ & $\begin{array}{l}\text { A professora retoma brevemente o que foi lido até aquele momento. } \\
\text { (exposição) }\end{array}$ \\
\hline
\end{tabular}




\begin{tabular}{|c|c|}
\hline $15: 25-18: 38$ & $\begin{array}{l}\text { Professora pede para } G \text { continuar a leitura e o aluno lê. Em seguida, a } \\
\text { professora pede para } R \text { continuar a leitura, mas como ele não sabia em que } \\
\text { ponto da leitura a classe estava, a professora, então, pede para o aluno Fo } \\
\text { prosseguir com a leitura. (leitura) }\end{array}$ \\
\hline $18: 38-21: 00$ & $\begin{array}{l}\text { A professora começa a falar, retoma alguns acontecimentos da narração e faz } \\
\text { perguntas para os alunos. (interação) }\end{array}$ \\
\hline 21:00- 22:00 & $\begin{array}{l}\text { A professora pergunta para } \mathrm{R} \text { se ele já conseguiu se encontrar na leitura. O } \\
\text { aluno diz que sim e então ela pede para ele continuar a leitura. (leitura) }\end{array}$ \\
\hline 22:00- 23:04 & $\begin{array}{l}\text { A professora pede que os alunos comentem a atitude de um personagem do } \\
\text { livro e expressem o que acham desse determinado personagem. (interação) }\end{array}$ \\
\hline 23:04- $24: 17$ & A professora pede para a aluna A continuar a leitura. (leitura) \\
\hline $24: 17-24: 54$ & $\begin{array}{l}\text { A professora interrompe, faz um comentário sobre um personagem do livro e } \\
\text { a classe responde ao comentário. (interação) }\end{array}$ \\
\hline $24: 54-27: 12$ & $\begin{array}{l}\text { Seguindo a sequência de leitura, a professora pede ao aluno } \mathrm{F} \text { para continuar. } \\
\mathrm{O} \text { aluno lê. Na sequência, é a vez do aluno L continuar a leitura. (leitura) }\end{array}$ \\
\hline $27: 12-32: 10$ & $\begin{array}{l}\text { Após a leitura, a professora faz um comentário sobre um objeto (que apareceu } \\
\text { no livro) super sofisticado para a época, já que não havia celular. Então, as } \\
\text { crianças começam a falar sobre aparelhos telefônicos. Ocorre até uma } \\
\text { discussão sobre a data de surgimento do telefone fixo e do celular. (interação) }\end{array}$ \\
\hline $32: 10-33: 46$ & A professora pede para $\mathrm{C}$ continuar a leitura. (leitura) \\
\hline $33: 46-35: 57$ & $\begin{array}{l}\text { A professora retoma o que foi lido e, para se assegurar que as crianças } \\
\text { compreenderam, faz algumas perguntas, como "Onde o personagem X } \\
\text { procurou o endereço?" abre-se, assim uma breve discussão sobre GPS, lista } \\
\text { telefônica, guia de ruas e mapas. (interação) }\end{array}$ \\
\hline $35: 57-41: 07$ & $\begin{array}{l}\text { A professora olha para Ra e indica que é sua vez de continuar a leitura. Ra lê. } \\
\text { A professora de prossegue indicando os alunos para lerem. Em um } \\
\text { determinado momento ela mesma realiza a leitura e os demais alunos } \\
\text { continuam até o fim do capítulo. (leitura) }\end{array}$ \\
\hline $41: 07-42: 35$ & A professora retoma o que foi lido e faz perguntas (interação) \\
\hline $42: 35-47: 22$ & $\begin{array}{l}\text { A professora pede para os alunos continuarem a leitura e indica o próximo } \\
\text { para continuar a partir daquele trecho. É a vez de } G \text {, depois de } R \text { e de Fo. } \\
\text { (leitura) }\end{array}$ \\
\hline $47: 22-47: 37$ & $\begin{array}{l}\text { A professora faz um comentário sobre a leitura e motiva uma pequena } \\
\text { interação. (interação) }\end{array}$ \\
\hline $47: 37-48: 23$ & A leitura passa para A (leitura) \\
\hline
\end{tabular}




\begin{tabular}{|l|l|}
\hline 48:23- 48:30 & $\begin{array}{l}\text { A professora faz uma pergunta sobre um fato específico da narração para os } \\
\text { alunos, alguém responde, ela não diz que está certo nem errado e em seguida, } \\
\text { pede para F continuar a leitura. (interação) }\end{array}$ \\
\hline 48:30- 49:23 & É a vez de F ler. (leitura) \\
\hline 49:23- 50:16 & $\begin{array}{l}\text { A professora pergunta se os alunos entenderam o que havia acontecido com o } \\
\text { personagem e explica o significado da palavra querosene. (interação) }\end{array}$ \\
\hline $50: 16-51: 03$ & $\begin{array}{l}\text { A professora convida os alunos a lerem mais um trecho para terminar o } \\
\text { capítulo do livro. (leitura) }\end{array}$ \\
\hline $51: 03-55: 20$ & $\begin{array}{l}\text { A professora cessa a leitura do livro e dá alguns avisos. Os alunos começam a } \\
\text { se levantar e a guardar o material no armário e a aula acaba. (exposição) }\end{array}$ \\
\hline
\end{tabular}

\begin{tabular}{|l|l|}
\hline \multicolumn{1}{|c|}{ Total (55 m 20s de aula) } & \multicolumn{1}{c|}{ Minutos e segundos } \\
\hline Leitura & $25 \mathrm{~min} 10 \mathrm{seg}$ \\
\hline Interação & $24 \mathrm{~min} 23 \mathrm{seg}$ \\
\hline Exposição & $5 \mathrm{~min} \mathrm{47} \mathrm{seg}$ \\
\hline
\end{tabular}


ANEXO B- MINUTAGEM DA AULA DE ITALIANO

\begin{tabular}{|c|c|}
\hline $\begin{array}{l}\text { Duração } \\
\text { (mm:ss) }\end{array}$ & Descrição \\
\hline $00-2: 35$ & $\begin{array}{l}\text { A professora entra em sala, cumprimenta os alunos, uma outra professora } \\
\text { aparece na porta e pede um livro emprestado, a professora de italiano procura- } \\
\text { o na bolsa, o livro não está, ela sai da sala para buscá-lo. Poucos alunos estão } \\
\text { dentro da sala (ainda estão voltando do intervalo), alguns aproveitam para } \\
\text { conversar comigo e perguntam sobre a filmadora que está na sala de aula. } \\
\text { A professora volta para a sala e interage um pouco com alguns alunos, } \\
\text { (pergunta se um deles não está com calor). Continua cumprimentando os } \\
\text { alunos que estão chegando e pergunta para a sala quem está faltando chegar } \\
\text { ainda. Em seguida, pergunta para os alunos se eles estão prontos para o } \\
\text { passeio do Carroção, se já fizeram as malas. (interação- início de aula- } \\
\text { assuntos diversos) }\end{array}$ \\
\hline $2: 35-3: 17$ & $\begin{array}{l}\text { A aluna } \mathrm{Ra} \text { Ra presenteia a professora com um doce, ela agradece, dá um } \\
\text { beijo na aluna. } \mathrm{O} \text { aluno Fo faz um comentário, diz que o doce parece bacalhau. } \\
\text { (interação- tema: doce) }\end{array}$ \\
\hline $3: 17-5: 12$ & $\begin{array}{l}\text { A aluna C chama a professora e fala que no dia anterior sua mãe começou a } \\
\text { preparar as coisas dela para o Carroção. A professora começa, então, a dar } \\
\text { algumas dicas do que levar para o passeio. M reclama que o e-mail que a } \\
\text { escola mandou, com a lista de itens para levar no passeio, não chegou para ela. } \\
\text { O aluno T diz que pegou a lista. Fo diz que tem a lista também e que vai } \\
\text { "ticando" o que ele já providenciou. A professora fala que são dois pares de } \\
\text { tênis e conta sobre a experiência dela no ano anterior. (interação-tema: } \\
\text { Carroção) }\end{array}$ \\
\hline 5:12- 6:06 & $\begin{array}{l}\text { Fo pergunta para a professora se ela é palmeirense e começam a falar de } \\
\text { futebol. A professora fala da vitória do time no dia anterior e pergunta quem } \\
\text { mais é Palmeirense. (interação-tema: futebol) }\end{array}$ \\
\hline 6:06- 13:10 & $\begin{array}{l}\text { A professora volta ao tema do Carroção e pergunta se alguém mais tem } \\
\text { dúvidas. As crianças começam a expor suas dúvidas. T fala que não tem a } \\
\text { ficha médica, explica que a mãe está na Itália e que esqueceu de falar com o } \\
\text { seu pai. A aluna Ra pergunta que horas que deve chegar na escola. O aluno Fo } \\
\text { reclama do horário. As crianças começam a falar juntas, ao mesmo tempo, } \\
\text { perguntam se devem que ir com o uniforme da escola. Perguntam também } \\
\text { quantas horas de viagem etc (interação- tema: Carroção) }\end{array}$ \\
\hline 13:10- 16:06 & $\begin{array}{l}\text { A professora encerra o assunto sobre o passeio e pede para os alunos pegarem } \\
\text { o livro didático. Alguns alunos mostram insatisfação quando ficam sabendo } \\
\text { que se trata de uma poesia. A professora pergunta porque eles não gostam de }\end{array}$ \\
\hline
\end{tabular}




\begin{tabular}{|c|c|}
\hline & $\begin{array}{l}\text { poesia e o aluno Fo responde que as poesias são falsas. Na sequência, antes de } \\
\text { começar a leitura, a professora explora o conhecimento das crianças sobre as } \\
\text { características estruturais da poesia. (interação- tema: poesia) }\end{array}$ \\
\hline $16: 06-16: 32$ & A aluna A realiza a leitura da poesia. (leitura) \\
\hline $16: 32-16: 40$ & $\begin{array}{l}\text { Na sequência, a professora pergunta para os alunos se alguém mais gostaria de } \\
\text { ler, como muitos levantam a mão, ela organiza a leitura de forma espacial e dá } \\
\text { a palavra ao aluno S. (interação- tema: organização da leitura) }\end{array}$ \\
\hline $16: 40-17: 25$ & O aluno $\mathrm{S}$ lê a poesia. (leitura) \\
\hline $17: 25-17: 52$ & $\begin{array}{l}\text { Durante a leitura, } C \text { faz uma pergunta de vocabulário e a professora, quando o } \\
\text { aluno } S \text { termina de ler, repete a dúvida de } C \text { para os demais alunos, } \\
\text { perguntando quem poderia explicar o que significava a palavra "fede", sem, no } \\
\text { entanto, traduzí-la. Após os palpites dos alunos, a professora afirma que existe } \\
\text { diferença entre fé e religião. (interação- tema: compreensão da poesia) }\end{array}$ \\
\hline $17: 52-22: 21$ & $\begin{array}{l}\text { Durante os próximos minutos alguns alunos se revezam na leitura da mesma } \\
\text { poesia. Após a leitura de Fo, a professora agradece os alunos que } \\
\text { participaram. Em seguida, pergunta para a classe se alguém gostaria de } \\
\text { continuar a leitura. Alguns alunos levantam a mão. A professora pede que se } \\
\text { acalmem, escolhe a aluna } \mathrm{C} \text { e depois vai escolhendo outros alunos: F, T, M e } \\
\text { Gi. (leitura) }\end{array}$ \\
\hline $22: 21-26: 09$ & $\begin{array}{l}\text { A professora agradece à todos pela leitura e pede para os alunos identificarem } \\
\text { e enumerarem todos os direitos presentes na poesia que acabaram de ler. } \\
\text { Depois, pede para eles abrirem o livro na página } 148 \text { e, então pergunta se o } \\
\text { texto que eles estão vendo naquele momento é uma poesia. A classe responde } \\
\text { que não. O aluno } T \text { diz que é um texto que trata dos direitos da convenção } \\
\text { internacional da infância.... A professora pede para } \mathrm{R} \text { ler a primeira parte. } \\
\text { (interação- tema: compreensão da poesia) }\end{array}$ \\
\hline $26: 09-26: 34$ & O aluno R lê uma pequena parte do texto. (leitura) \\
\hline 26:34- 29:06 & $\begin{array}{l}\text { A professora faz algumas perguntas para os alunos a fim de verificar a } \\
\text { compreensão da leitura. (interação- tema: texto informativo os direitos das } \\
\text { crianças) }\end{array}$ \\
\hline 29:06- 30:30 & $\begin{array}{l}\text { A professora pede para os alunos fazerem uma leitura silenciosa do texto. } \\
\text { (leitura) }\end{array}$ \\
\hline $30: 30-34: 20$ & $\begin{array}{l}\text { A professora faz outras perguntas para os alunos sobre o mesmo texto, tais } \\
\text { como: qual é o tema tratado pelo texto, quando e porque ele foi escrito etc. } \\
\text { (interação- tema: texto informativo os direitos das crianças) }\end{array}$ \\
\hline $34: 20-35: 54$ & $\begin{array}{l}\text { A professora pede para Gi ler a primeira frase do texto em voz alta e, em } \\
\text { seguida, pergunta para os alunos o que significa aquilo que foi lido. Chama a } \\
\text { atenção para o tipo de linguagem (metáfora) que é usada. Professora e alunos }\end{array}$ \\
\hline
\end{tabular}




\begin{tabular}{|c|c|}
\hline & discutem sobre a violência infantil. (interação- tema: violência infantil) \\
\hline $35: 54-39: 20$ & $\begin{array}{l}\text { A professora pede para a aluna } M \text { ler outra frase do texto e pergunta para os } \\
\text { alunos o que significa vida e liberdade. Os alunos participam. A professora } \\
\text { relembra que na Roma antiga, os pais queriam sempre um filho homem, } \\
\text { quando nascia uma mulher matavam-na. Na época atual, lembrou das famílias } \\
\text { que não tem condições financeiras para cuidar dos seus filhos e, muitas vezes, } \\
\text { os abandonam. (interação- tema: vida e liberdade) }\end{array}$ \\
\hline $39: 20-41: 53$ & $\begin{array}{l}\text { A professora pede para o aluno } \mathrm{T} \text { fazer a leitura da frase seguinte. Após a } \\
\text { leitura inicia-se uma pequena discussão sobre o direito das crianças de serem } \\
\text { ouvidas. (interação- tema: direito de ser ouvido) }\end{array}$ \\
\hline $41: 53-42: 56$ & $\begin{array}{l}\text { A professora pede para Fo ler a próxima frase e a aluna } M \text { pede autorização } \\
\text { para expor o que entendeu. A compreensão gira em torno da igualdade de } \\
\text { direitos, ou seja, não importa a raça, a religião ou sexo, todas as crianças são } \\
\text { iguais e devem ter os mesmos direitos. (interação- tema: igualdade de } \\
\text { direitos) }\end{array}$ \\
\hline $42: 56-47: 52$ & $\begin{array}{l}\text { A professora indica Roberto para fazer a leitura e Rebeca comentar a seguinte } \\
\text { frase "as crianças tem direito ao afeto" Em seguida, outros alunos também } \\
\text { participam da discussão.A professora pede para G ler a próxima frase. } \\
\text { (interação- tema: direito a receber amor) }\end{array}$ \\
\hline $47: 52-51: 40$ & $\begin{array}{l}\text { A professora pede para alguém fazer um comentário sobre o que } \mathrm{G} \text { acabou de } \\
\text { ler. As crianças participam falam sobre guerra, violência e contam fatos atuais } \\
\text { que assistiram na televisão. (interação- tema: violência) }\end{array}$ \\
\hline $51: 40-58: 05$ & $\begin{array}{l}\text { A aluna C lê outra frase e inicia-se uma discussão sobre direito à educação. As } \\
\text { crianças comentam e compartilham casos que ouviram ou vivenciaram. } \\
\text { (interação- tema: direito à educação) }\end{array}$ \\
\hline $58: 05-60: 00$ & $\begin{array}{l}\text { A professora pede à } \mathrm{L} \text { e à } \mathrm{F} \text { para lerem os últimos itens que referem-se ao fato } \\
\text { das crianças terem direito à brincar, descansar e a viverem na cidade. A } \\
\text { professora retoma o título da poesia "La pace verrà" e afirma que a paz só vai } \\
\text { chegar quando as pessoas souberem respeitar esses direitos e que as crianças } \\
\text { que não tiverem esses direitos respeitados, serão adultos que não saberão } \\
\text { respeitar os direitos dos outros. Conclui assim e encerra a aula. (exposição) }\end{array}$ \\
\hline
\end{tabular}

\begin{tabular}{|l|l|}
\hline \multicolumn{1}{|c|}{ Total (60 m 0s de aula ) } & \multicolumn{1}{c|}{ Minutos e segundos } \\
\hline Interação & $51 \mathrm{~min} 17 \mathrm{seg}$ \\
\hline Leitura & $6 \mathrm{~min} 48 \mathrm{seg}$ \\
\hline Exposição & $1 \mathrm{~min}$ e $55 \mathrm{seg}$ \\
\hline
\end{tabular}




\section{ANEXO C- TRANSCRIÇÃO LIVRE DA AULA DE PORTUGUÊS}

\begin{tabular}{|c|c|}
\hline $\begin{array}{l}\text { Duração } \\
\text { (mm:ss) }\end{array}$ & Descrição \\
\hline $00-3: 13$ & 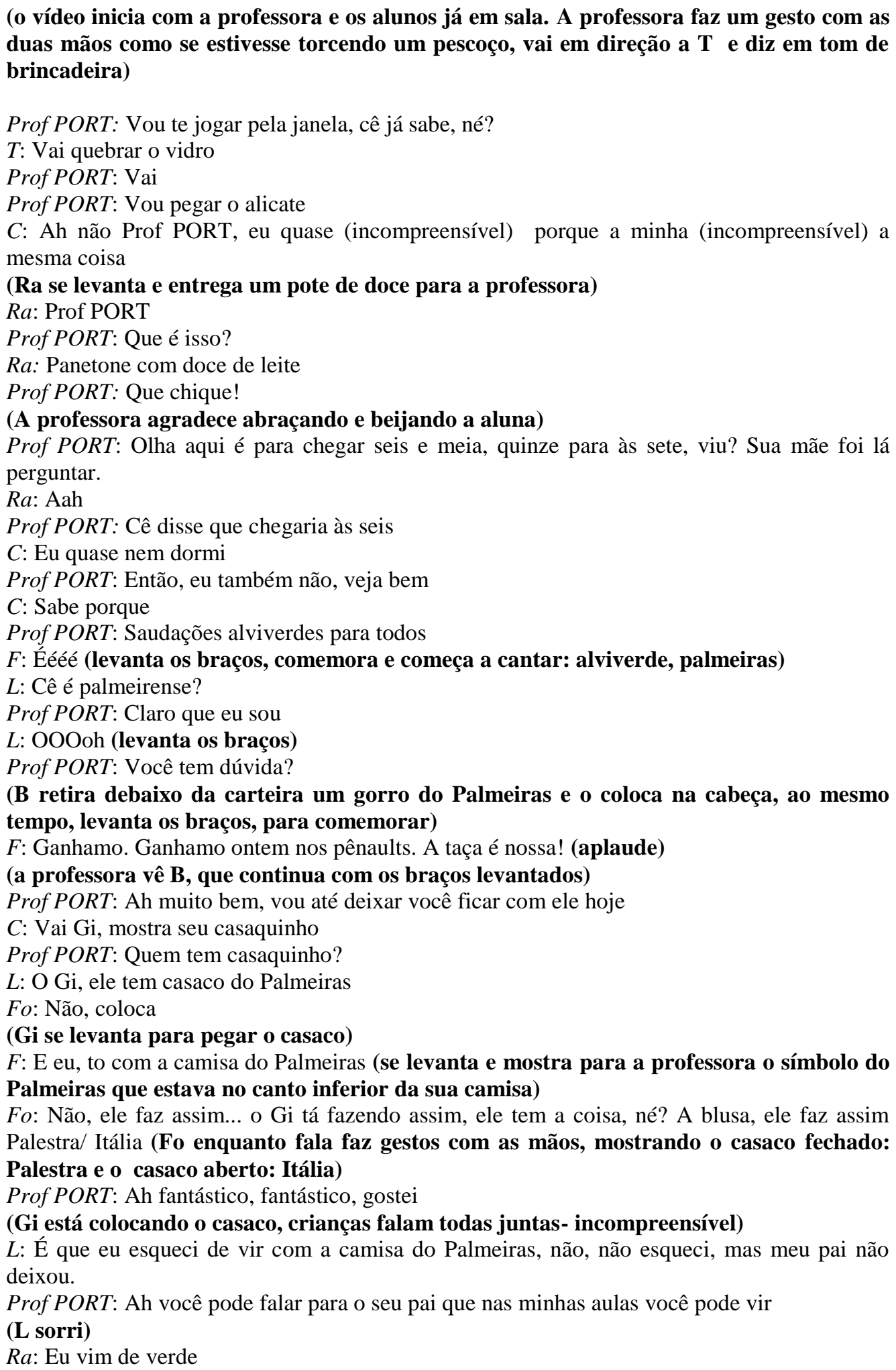 \\
\hline
\end{tabular}




\begin{tabular}{|c|c|}
\hline & $\begin{array}{l}\text { Prof PORT: É, ta vendo gente... gente inteligente } \\
\text { (C pega uma caneta verde e mostra para a professora e professora faz um sinal de } \\
\text { positivo com o dedo) } \\
\text { Prof PORT: Bom, meus amores vamos lá, que eu acho que conseguimos terminar o livro hoje, } \\
\text { acho não, vamos terminar } \\
\text { (C comemora aplaudindo) } \\
\text { Prof PORT: Pega, por favor, o Gênio do Crime } \\
\text { L: Já? } \\
\text { Prof PORT: Só tem essa aula hoje, não tem outra } \\
\text { (As crianças se levantam para pegar o livro e conversam entre si e alguns com a } \\
\text { professora. Um minuto depois) }\end{array}$ \\
\hline $3: 13-9: 53$ & 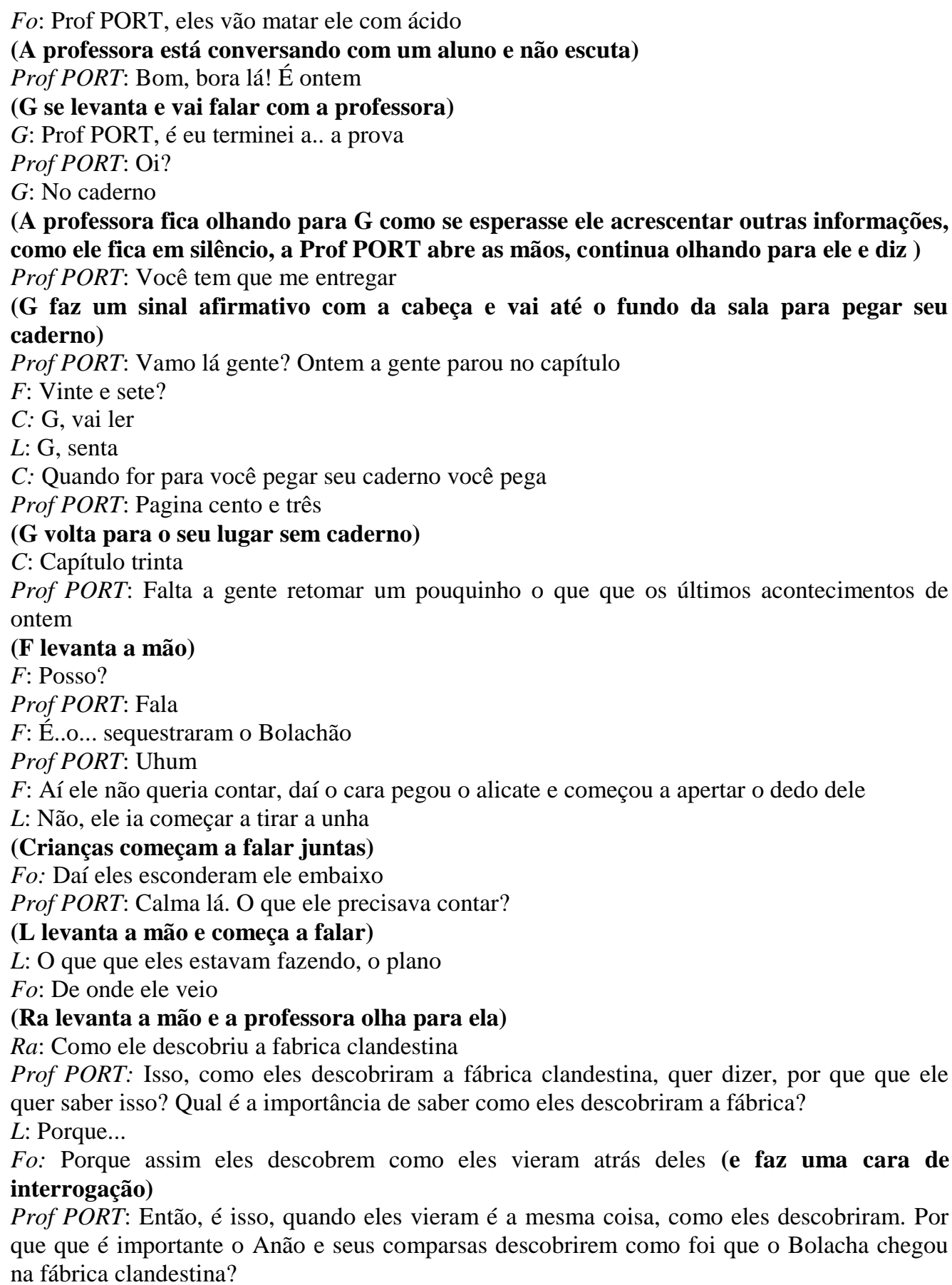 \\
\hline
\end{tabular}




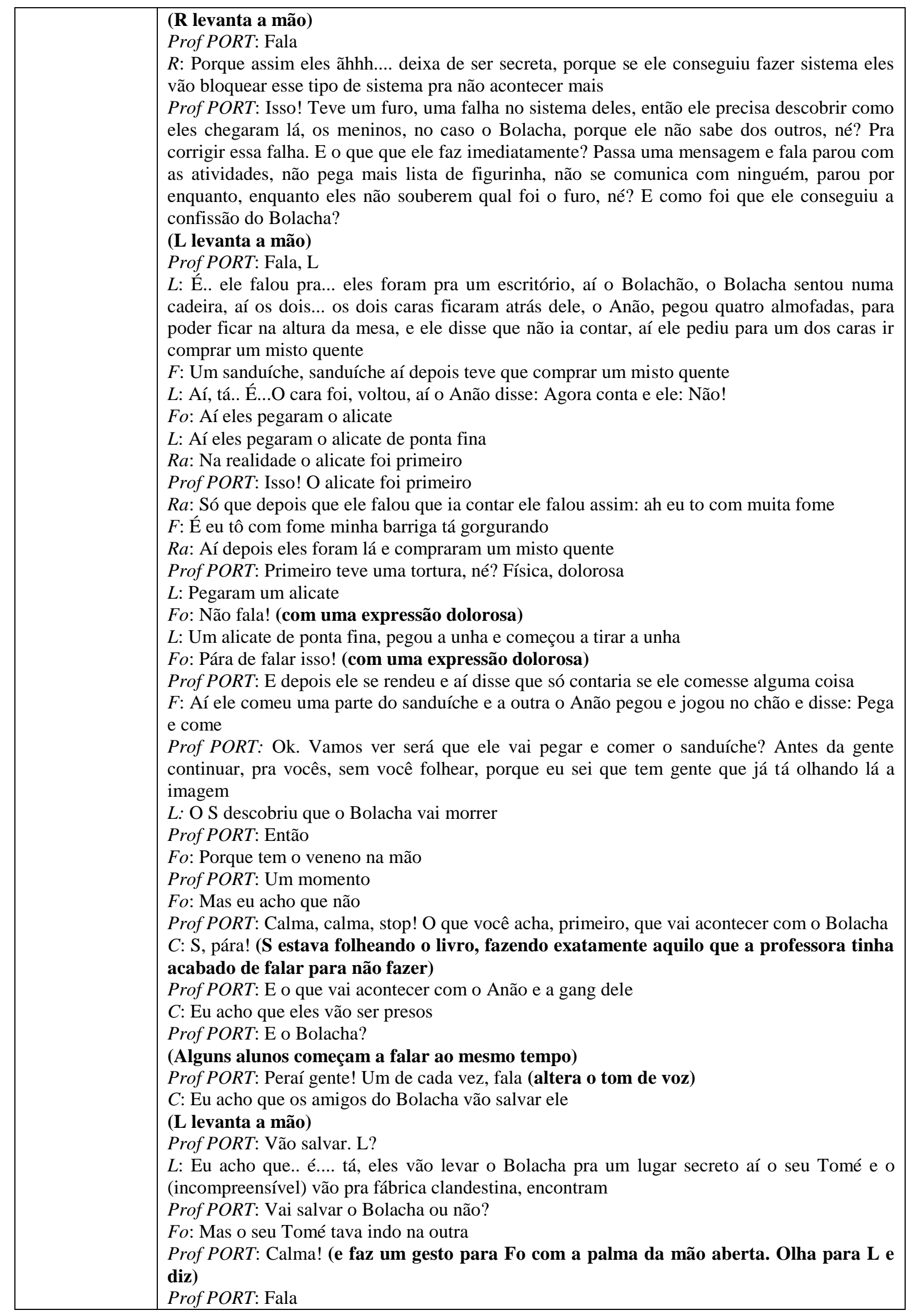




\begin{tabular}{|c|c|}
\hline & $\begin{array}{l}\text { L: Mas aí, descobrem a passagem secreta e quando os caras e o Anão forem botá o Bolacha no } \\
\text { ácido, eles pegam o Bolacha e prendem o Anão e os caras } \\
\text { Prof PORT: Tá, mas o Fo falou, tem um problema aí nessa sua resolução, fala } \\
\text { Fo: É, mas o seu Tomé tava mandando a polícia na outra fábrica e também } \\
\text { Prof PORT: Num outro endereço, né? } \\
\text { Fo: É, se também ele mandasse na rua do outro planeta lá, não ia descobrir, porque tava lá } \\
\text { escondido embaixo. E teve uma parte que ele tá com ácido na mão e depois } \\
\text { Prof PORT: Isso você viu o desenho, né? A gente não vai explorar a imagem ainda, tá? } \\
\text { (R levantou a mão) } \\
\text { Prof PORT: R } \\
R \text { : Eu acho que eles vão conseguir salvar o Bolacha, é mas eu acho que o Anão vai ser preso } \\
\text { com os outros e a fábrica debaixo eu acho que, com certeza, vai ser fechada, depois eu acho } \\
\text { que também vai acontecer alguma coisa com o Bolacha, não sei.. } \\
\text { (Ra levanta a mão) } \\
\text { Prof PORT: Ra } \\
\text { Ra: Eu acho que o Mister John vai salvar o Bolacha } \\
\text { Prof PORT: Humm, o Mister John, não podemos esquecer desse personagem } \\
\text { Fo:Ééééé' verdade } \\
\text { Prof PORT: O detetive, o invicto, né? Se alguém vai descobrir alguma coisa aí, vai ser ele, né, } \\
\text { gente? Não tem essa fama à toa } \\
R: \text { Mas não vai ser ele } \\
\text { Prof PORT: Será que não? } \\
R: \text { Não, eu tenho certeza } \\
\text { Prof PORT: Você tem certeza? (com tom doce). } \\
\text { (A professora coloca os óculos e olha para o livro) } \\
\text { Prof PORT: Vamos lá então, gente, página } 103 \text {. A gente vai fazer uma ordem, vamos } \\
\text { seguindo assim } \\
F: \text { Capítulo trinta, né? } \\
\text { Prof PORT: E aí eu vou só falando pra mudar, tudo bem? Então já fica ligado, porque você } \\
\text { sempre vai ser na mesma sequência de alguém, tá? M, quer começar? }\end{array}$ \\
\hline $9: 53-10: 38$ & $\begin{array}{l}\text { (M começa a leitura) } \\
\text { Vamos ver o que aconteceu na escola depois que o Bolachão saiu da classe. } \\
\text { Logo que o Raimundo abriu a cortina, o Mister também desconfiou, e principiou a fazer o } \\
\text { mesmo pensamento que a Berenice fizera. Distraiu-se pelo pedido do gordo para ir lá fora, e, } \\
\text { em seguida, para azar do Mister, o badalão do Zé Tavares desandou a fazer pergunta: }\end{array}$ \\
\hline $10: 38-12: 00$ & $\begin{array}{l}\text { Prof PORT: Então gente, olha só, o livro, ele tá trabalhando com dois momentos, dois tempos } \\
\text { diferentes, tá? O que a gente tava vendo até agora tá acontecendo lá na fábrica clandestina, } \\
\text { tudo bem? Com o Bolacha e com os meninos que tão investigando, mas a gente não pode } \\
\text { esquecer que essa história também tava acontecendo dentro da escola. Então, o que que o } \\
\text { autor tá fazendo com a gente, o narrador na verdade tá nos dizendo o que que tá acontecendo } \\
\text { ao mesmo tempo no outro cenário, porque quando acontece uma coisa em um cenário o outro } \\
\text { pára? } \\
\text { Classe: Não } \\
\text { Prof PORT: Pensa aqui, você tá aqui na escola agora, neste cenário, assistindo a aula, lendo o } \\
\text { livro, lá na sua casa, que é o outro cenário, de onde você veio, parou todo mundo? Dormiu? } \\
\text { Classe: Não } \\
\text { Prof PORT: Não. As pessoas } \\
\text { C: Eu também, às vezes, fico pensando assim, o que acontece assim, eu tô na minha casa aí eu } \\
\text { penso o que tá acontecendo na casa da Ra } \\
\text { Prof PORT: Isso, lá na sua casa tem coisas acontecendo, lá na rua tem coisas acontecendo, lá } \\
\text { no estádio do Palmeiras tem coisas acontecendo. Tudo está acontecendo ao mesmo tempo, é } \\
\text { concomitante, tá? Então, não dá pra gente pensar porque a gente tá focando um cenário que o } \\
\text { resto parou, isso não acontece, tudo bem? Bora lá então, vamos ver o que, continuar a história }\end{array}$ \\
\hline
\end{tabular}




\begin{tabular}{|c|c|}
\hline & $\begin{array}{l}\text { Fo: Só se todo mundo começar a dormir } \\
\text { Prof PORT: É, tipo, meio Bela Adormecida, né? Vai Gi }\end{array}$ \\
\hline $12: 00-12: 27$ & $\begin{array}{l}\text { (Gi continua a leitura) } \\
\text { - Professor, por que na Escócia cai neve e no Brasil não cai? } \\
\text { Era de naná aquele Zé e desarrumava a concentração do pensamento do Mister. Foi } \\
\text { respondendo maquinalmente enquanto engrenava as ideias. } \\
\text { "O cortina, o lista com letras grandes, o cortina o lista com letras grandes. Ter xaveco aí". }\end{array}$ \\
\hline $12: 27-12: 48$ & $\begin{array}{l}\text { Prof PORT: Que que é xaveco, gente? } \\
\text { C: Xaveco, eu acho que eu sei, é aquele carinha da turma da Mônica. } \\
\text { Prof PORT: Ah é também, mas se fosse seria escrito com letra maiúscula, tá C? Porque aí } \\
\text { seria o nome do personagem } \\
\text { Rodrigo: Acho que quer dizer que tem alguma coisa que tá lá } \\
\text { Prof PORT: Isso } \\
\text { Rodrigo: Que num tá errado... que num tá certo } \\
\text { Prof PORT: Exato! É uma coisa que num tá certo. Perfeito! Vai, Gi }\end{array}$ \\
\hline $12: 48-14: 59$ & $\begin{array}{l}\text { (Gi volta a ler) } \\
\text { Mas o Zé, embora de natural fosse chato permanente, estava naquele dia de lelé na cuca. } \\
\text { - Professor, por que que lá tem rainha e aqui não tem? } \\
\text { O Mister respondia e continuava pensando: } \\
\text { "O cortina estar fechado, ele abrir o cortina, o lista ter letras grandes, enton, enton..." } \\
\text { - Professor, qual é mais forte? A Rússia ou os Estados Unidos? } \\
\text { Prof PORT: T } \\
\text { "Yes, mim matar a problema "- pensou o Mister } \\
\text { Não respondeu ao Zé Tavares e a classe viu o que classe nenhuma do mundo tinha visto } \\
\text { antes: o professor desceu pernalongando do estrado e pulou a janela. } \\
\text { Prof PORT: Pensa, eu não posso fazer isso aqui, né? } \\
\text { (alguns alunos sorriem) } \\
\text { Fo: Ah vai vai faz! } \\
\text { Prof PORT: Ahaha engraçadinho! Vai, T } \\
\text { (T continua a leitura) } \\
\text { Pulou o muro da casa vizinha também e abriu a porta com chave falsa especial, mas chegou } \\
\text { tarde porque nessa hora o Volks bordô já estava virando a esquina com o gordo dentro. O } \\
\text { escocês revirou a casa inteira e não achou pista que prestasse, nem papel, nem bituca de } \\
\text { cigarro, nem fio de cabelo e nem impressão digital, só a dos dedinhos redondos do gordo. } \\
\text { Fuçou pela vizinhança, descobriu o endereço do dono da casa e foi lá. O homem disse que } \\
\text { tinha alugado a casa para um cabelo branco narigudo e que chamava João da Silva, nome } \\
\text { falso, lógico. Outra informação o dono não sabia. }\end{array}$ \\
\hline $14: 59-15: 25$ & $\begin{array}{l}\text { Prof PORT: Então, quase, né? Naquele momento que o gordo tava sendo levado, quase que o } \\
\text { Mister conseguiu salvar o gordo. Vocês viram aqui, quando ele chegou o carro tava virando a } \\
\text { esquina, tá? Porém se ele tivesse salvado o gordo, o gordo não chegaria na fábrica clandestina, } \\
\text { não é? Ele só chegou lá porque ele foi levado até lá, não é isso? Vai lá, G }\end{array}$ \\
\hline
\end{tabular}




\begin{tabular}{|c|c|}
\hline $15: 25-18: 38$ & $\begin{array}{l}\text { (G lê o seguinte trecho) } \\
\text { O Guarda que dirigia o trânsito defronte à escola disse ao Mister que o narigudo usava um } \\
\text { Volks bordô e o Mister foi ao departamento da cidade e copiou numa maquininha de } \\
\text { fotocópia a relação de todos os donos de Volks bordô de São Paulo e tinha mais Volks bordô } \\
\text { em São Paulo que João da Silva. } \\
\text { (G ia continuar a leitura, mas a professora o interrompe e adverte) } \\
\text { Prof PORT: Tem um ponto, tem que parar, tá? } \\
\text { Prof PORT: } R \\
\text { (R estava perdido e não se encontrava na leitura, então a professora pediu para Fo } \\
\text { prosseguir) } \\
\text { Prof PORT: Fo } \\
\text { (Fo lê) } \\
\text { O Mister sabia que era pista fraca porém o bom detetive não as despreza. Por cima ainda } \\
\text { assuntou na rua inteira; açougueiro, donos de bar, pipoqueiro, sorveteiro, lixeiro, carteiro, } \\
\text { eletricista e encanador que tinham feito conserto lá mas ninguém sabia nada. Analisou no } \\
\text { laboratório embutido, que levava no helicóptero, as poeirinhas do chão da casa. O Jonas } \\
\text { classificou-as e grudou num caderno por ordem alfabética, para conferir com outras } \\
\text { poeirinhas quando fosse preciso. } \\
\text { Fizeram reunião na fábrica do seu Tomé. O coitado, quando soube que o gordo sumiu, ficou } \\
\text { numa aflição grande e estava no ponto de começar a chorar e ter outro ataque dos nervos. O } \\
\text { gerente empinou o queixo e falou: } \\
\text { - Eu não disse! Eu disse, eu avisei, ninguém me ouviu; isso não era coisa para crianças. } \\
\text { Agora está aí! }\end{array}$ \\
\hline $18: 38-21: 00$ & $\begin{array}{l}\text { Prof PORT: Então, gente, oh a gente tá vendo tudo isso que tá acontecendo aqui, tá } \\
\text { acontecendo lá na fábrica, o gordo sendo torturado, pressionado, então, aqui, o que que ele vai } \\
\text { fazer, ele vai nos explicar como é que as pessoas que conviviam com o gordo e tavam } \\
\text { envolvidas na investigação estavam agindo. Essa é a notícia de que o gordo sumiu. Então, } \\
\text { como é que o Mister tá usando seus métodos para descobrir aonde ele foi, quem levou, né? Ele } \\
\text { tem uma pista muito simples que é o carro e um nome, que era um nome falso, onde será que } \\
\text { ele foi que ele conseguiu a lista de donos de fusca bordô. Onde cês acham que é esse lugar? } \\
\text { Onde poderia ser na verdade? } \\
C: \text { Naquele lugar } \\
\text { Fo: Maquininha de fotocópia } \\
\text { Prof PORT: Então, mas aonde? Ele foi ao departamento da cidade. O que que seria esse } \\
\text { departamento da cidade? Qual departamento seria esse? } \\
\text { Fo: Na polícia. } \\
T: \text { Na delegacia. } \\
\text { Prof PORT: Na delegacia? Será que na delegacia tem uma relação de carros e o nome do dono } \\
\text { do carro, a cor e tudo mais? } \\
L \text { e Ra: Sim. } \\
C: \text { É..não... na concessionária } \\
\text { Prof PORT: Não entendi. } \\
C: \text { Concessionária de carros. } \\
\text { Prof PORT: Concessionária de carro? O que que é uma concessionária? O que que faz uma } \\
\text { concessionária? }\end{array}$ \\
\hline
\end{tabular}




\begin{tabular}{|c|c|}
\hline & $\begin{array}{l}\text { trânsito. A polícia, a delegacia de polícia pode ter essa informação? Pode, mas ele não foi } \\
\text { numa delegacia , aqui ele fala que ele foi ao departamento, departamento de trânsito, tá? } \\
\text { Agora tem um problema, né? Ele descobriu que tem mais carro, mais fusca, mais Volkswagen } \\
\text { bordô do que João da Silva em São Paulo. Então fica difícil saber quem é, de quem é esse } \\
\text { carro, de fato, tá? }\end{array}$ \\
\hline $21: 00-22: 00$ & $\begin{array}{l}\text { Prof PORT: R, já se achou? } \\
\text { (R balança a cabeça afirmativamente) } \\
\text { Prof PORT: Então vai } \\
\text { (R lê) } \\
\text { - Meu bom gorducho, meu bom menino! - exclamou seu Tomé. - Deve estar em perigo; você } \\
\text { tinha razão, gerente, fui muito egoísta, me aproveitei destas crianças, só pensava em mim, na } \\
\text { minha fábrica, nas minhas dores de cabeça. Ah! Como pude fazer isso. } \\
\text { - Calma, seu Tomé - disse Edmundo. - o Bolacha não é bobo, está seguindo o homem e daqui } \\
\text { a pouco manda as notícias. O gordo não é trouxa, não o apanharão facilmente. } \\
\text { - Mas se pegam matam- continuou o gerente. - Uma criança, o senhor me ouviu, eu disse, eu } \\
\text { disse. }\end{array}$ \\
\hline $22: 00-23: 04$ & $\begin{array}{l}\text { Prof PORT: O que cês acham desse gerente, gente? } \\
\text { Ra: Que chato. } \\
\text { L: Acho que ele tá causando drama } \\
\text { Prof PORT: Se acha? (risos) } \\
L: \text { Acho que ele trabalha pro dono da fábrica clandestina e só tá deixando o Tomé mais } \\
\text { (Ra interrompe e na sequência L completa) } \\
\text { Ra: Então, ele é muito suspeito porque ele não quer que eles façam isso } \\
L: \text { Mais estressado e não quer que as crianças participem, porque as crianças são mais } \\
\text { espertas, mais práticas do que o Mister e eles conseguem descobrir a fábrica clandestina e } \\
\text { salvar o gordo antes que eles matem } \\
\text { Prof PORT: É, a Ra também falou uma coisa interessante, ele é } \\
\text { Ra: Ele é um pouco suspeito, porque ele fica falando ah isso não é coisa de criança, melhor } \\
\text { não deixar eles ir. Será que tem alguma coisa que ele tá escondendo? } \\
\text { Prof PORT: Pode ser. Alguém mais acha? } \\
F \text { : Eu acho } \\
C: \text { Eu acho que ele só trabalha lá com seu Tomé pra espionar o que ele tá fazendo } \\
\text { Prof PORT: Ahhhh } \\
C: \text { E depois as crianças foram lá, é a mesma coisa que a Ra falou, depois ele fica falando que } \\
\text { não, só pra eles não descobrirem onde é que era a fábrica } \\
\text { Prof PORT: Ok }\end{array}$ \\
\hline 23:04- 24:17 & $\begin{array}{l}\text { Prof PORT: A, sua vez. } \\
\text { (A prossegue a leitura) } \\
\text { É mesmo! - choramingou seu Tomé. - Você bem que disse, gerente, e eu não ouvi. Ah meu } \\
\text { gordinho, a vida dele vale mais que minha fábrica, vale mais que tudo; não importa que meu } \\
\text { negócio se rebente, quero ficar pobre mendigo de pé no chão se isso for preciso para ter o } \\
\text { gordo vivo! Minha Santíssima Trindade! } \\
\text { - Eu disse. } \\
\text { - Senhor gerente- interrompeu o Mister.- Mim ser um homem muitíssimo do calmo, mim só } \\
\text { perder o meu paciência uma vez no vida com uma bandida espanhol que amarrar mim numa } \\
\text { cadeira me dar um tiro no meu barriga e depois jogar um balde de água fervendo no meu } \\
\text { cabeça. Mas o senhor estar muito chato, senhor gerente, se o senhor repetir mais uma vez " } \\
\text { eu disse" mim dar um tapa no seu cara. }\end{array}$ \\
\hline
\end{tabular}




\begin{tabular}{|c|c|}
\hline $24: 17-24: 54$ & $\begin{array}{l}\text { Prof PORT: Nossa } \\
\text { F: Dar um tapa no seu cara, entendeu? } \\
\text { Prof PORT: Ele sobreviveu a um tiro na barriga e um balde de água fervendo na cabeça, hein, } \\
\text { o cara é poderosíssimo } \\
\text { F: Dá a entender no seu cara, tipo, no seu segurança } \\
\text { Prof PORT: Seu cara não, esse cara, na cara do gerente } \\
F \text { : Eu sei } \\
C \text { : Prof PORT, uma vez eu assisti um filme, que tinha um cara, é assim, um filme meio, é } \\
\text { desenho animado, que ele botou uma placa de ferro na cabeça, porque ele tinha levado um } \\
\text { tiro, mas não aconteceu nada porque tinha uma placa de ferro } \\
\text { Prof PORT: Hum,ok }\end{array}$ \\
\hline $24: 54-27: 12$ & $\begin{array}{l}\text { Prof PORT: Vamos lá, F } \\
\text { (F lê) } \\
\text { o gerente desempinou um pouco o queixo e respondeu: } \\
\text { - Estou apenas lembrando que tinha razão quando adverti sobre o perigo de meter crianças } \\
\text { com bandidos. O senhor está procurando me intimidar com a violência e eu estou } \\
\text { argumentando com a razão. A lógica do meu raciocínio é perfeita, só mesmo um louco não } \\
\text { entende a verdade do que eu disse: criança em investigação é perigoso, seu Tomé não tinha o } \\
\text { direito de deixar, e tanto estava errado que foi tudo escondido dos pais. E os fatos } \\
\text { comprovam meu pensamento; o gordo pode até escapar mas corre perigo e não temos direito } \\
\text { de pôr os filhos dos outros em risco. Eu argumento com a razão, seu Mister. } \\
\text { - Senhor gerente, a história do mundo mostrar que os chatos ser bichos muito lógicos e ter } \\
\text { sempre razon. Mas a problema fundamental do vida non ser ter razon, a problema } \\
\text { fundamental do vida ser non ser chata. } \\
\text { Prof PORT: L } \\
\text { (L prossegue) } \\
\text { O gerente empalideceu e Edmundo falou: } \\
\text { - O importante é sair pela cidade procurando o gordo, isso que interessa agora. } \\
\text { - Sim, ser verdade. } \\
\text { - E eu que faço? - perguntou seu Tomé. - Quero ajudar também mas não sei por onde } \\
\text { começar. } \\
\text { - A senhor fica aqui na fábrica. Ser capaz de Bolachon telefonar. Se a gorda telefonar, o } \\
\text { senhor apertar o boton desse caixa que eu deixar aqui, que no mesmo hora fazer tocar um } \\
\text { campainha que ter no minha paletó. Aí, o senhor falar no caixa, que mim ouvir no lugar que } \\
\text { mim estiver. }\end{array}$ \\
\hline $27: 12-32: 10$ & $\begin{array}{l}\text { Ra: Que chique } \\
\text { Prof PORT: Chique né? Equipamento super sofisticado pra época, hein? Aperta o botão e fala } \\
\text { com ele lá no paletó, não tinha celular ainda, né? } \\
C: \text { Nossaaa } \\
\text { Prof PORT: Nossa mesmo } \\
L: \text { A C, nossa, não conseguiria viver sem } \\
\text { Prof PORT: Sem celular? } \\
L: \text { Não } \\
C: \text { É, eu não conseguiria viver } \\
B: \text { Nem eu } \\
C: \text { Não vivo sem meu telefone } \\
\text { Prof PORT: É mesmo, você fica pendurada no celular o tempo inteiro? } \\
C: \text { Em todo lugar que eu vou eu uso meu telefone } \\
B: \text { Eu fico } 24 \text { horas com meu celular } \\
C: \text { Eu chego em casa o telefone tá acabando a bateria }\end{array}$ \\
\hline
\end{tabular}




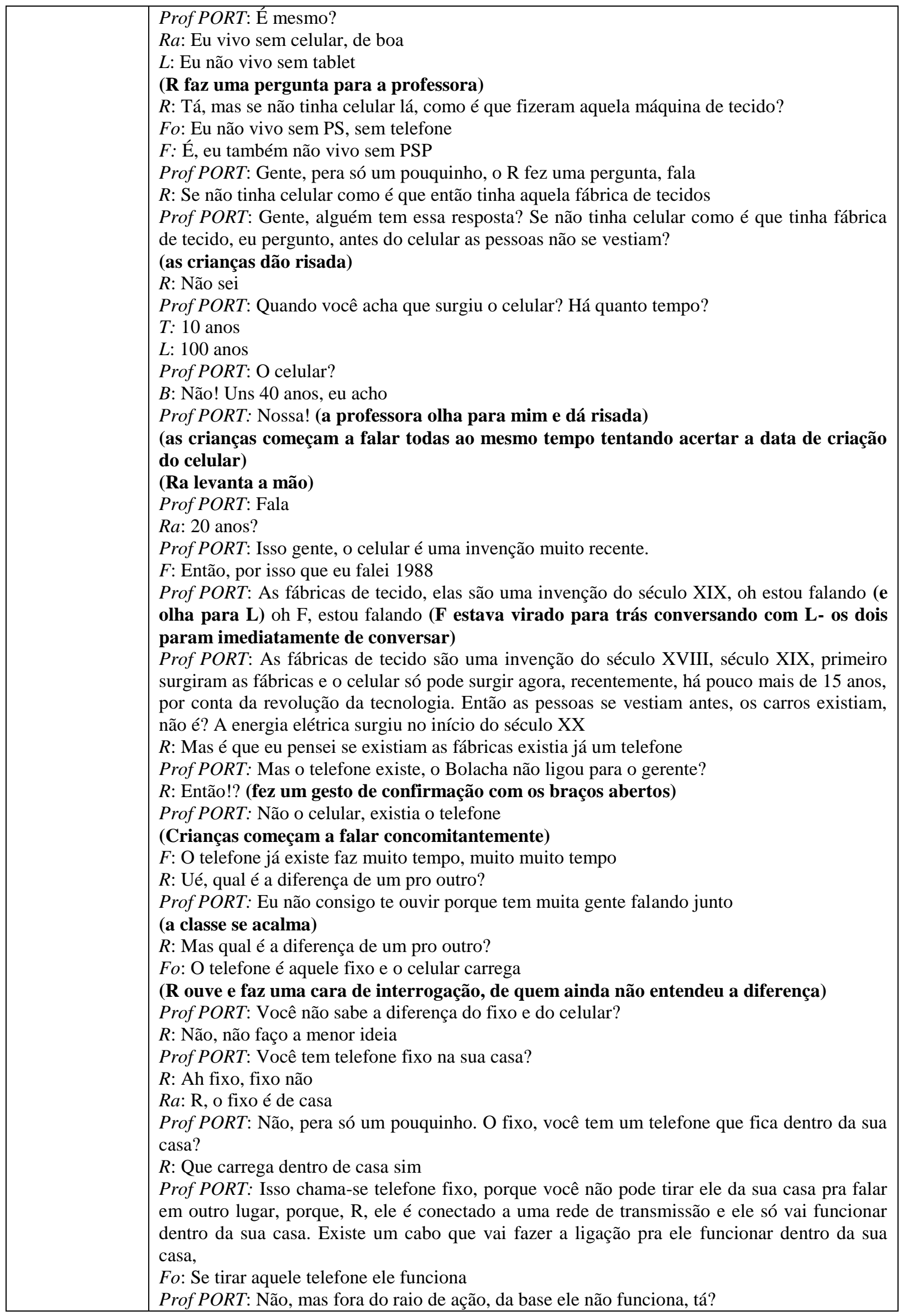




\begin{tabular}{|c|c|}
\hline & $\begin{array}{l}R: \text { Mas o meu não tem cabo. } \\
\text { Prof PORT: Ele está conectado na base do seu telefone } \\
R \text { : Então, mas ele não tem cabo, o meu fixo } \\
\text { Prof PORT: Tem que ter, R } \\
R: \text { Não tem cabo } \\
\text { Fo: Ah! É aquele lá } \\
\text { Prof PORT: R, ele está conectado à base do seu telefone. Oh oh, Fo! (Fo tinha se levantado } \\
\text { para explicar para R o que era a base do telefone, quando a professora o repreendeu, ele } \\
\text { voltou para o seu lugar) } \\
\text { Prof PORT: Você chega em casa hoje e vai olhar } \\
R: \text { Sim, não tem cabo, posso ir até meu quarto } \\
\text { Fo: É esse aqui (faz um gesto com a mão indicando o tamanho do aparelho, mas R não } \\
\text { pode ver porque Fo está sentado atrás dele) } \\
\text { Prof PORT: Você leva uma parte dele, R } \\
R: \text { Não entendi ainda } \\
\text { Prof PORT: Você carrega na sua casa uma parte dele, a outra parte você tem que por pra } \\
\text { carregar numa base, não tem? } \\
R: \text { Sim } \\
\text { Prof PORT: Aquilo está conectado a um cabo, este cabo que faz a ligação pra você poder se } \\
\text { comunicar (Fo fala algo baixinho e R começa a rir) Tudo bem? Por que que você tá rindo? } \\
R: \text { Não sei } \\
\text { Prof PORT: Tá tudo bem? } \\
\text { (R continua rindo) } \\
\text { Prof PORT: Não tô entendendo porque você tá rindo } \\
R: \text { Eu começo a rir às vezes } \\
\text { Prof PORT: Estranho isso, né? Sem motivo } \\
\text { (Professora coloca os óculos, R volta a olhar para o livro e a aula segue) }\end{array}$ \\
\hline $32: 10-33: 46$ & $\begin{array}{l}\text { Prof PORT: Vamos lá, gente. C } \\
\text { (A aluna C lê) } \\
\text { O palpite do Mister confirmou-se, e, às nove da noite, seu Tomé recebeu a telefonada do } \\
\text { gordo. } \\
\text { Apertou logo o botão que o Mister tinha falado e tocou a campainha no paletó do Mister na } \\
\text { hora que o escocês estava vistoriando uma casa do Ibirapuera onde foi parar por causa duma } \\
\text { pista errada. O Mister puxou um fiozinho e meteu no ouvido e ouviu seu Tomé dar o } \\
\text { endereço: rua Veneta 99. Procurou a rua Veneta na lista telefônica mas não achou, } \\
\text { perguntou daqui dali, porque há ruas que não estão nem na lista e nem no guia da cidade e se } \\
\text { convenceu que a rua não existia. Então foi para a fábrica de seu Tomé; Edmundo, Pituca, o } \\
\text { gerente e Jonas tinham chegado há pouco, depois de virar a tarde inteira sem achar nada. }\end{array}$ \\
\hline $33: 46-35: 57$ & $\begin{array}{l}\text { Prof PORT: Então, olha só o que tava acontecendo lá depois que o gordo ligou pra dar o } \\
\text { endereço e o Anão se fez passar por ele e deu o endereço errado. Seu Tomé recebeu o } \\
\text { telefonema e já acionou o comunicador com o Mister, ele foi atrás daquela rua e ele já sabe } \\
\text { que não existe essa rua, então, possivelmente ele vai entender que é um endereço falso. Então, } \\
\text { vamos lá pra fábrica, pra fazer uma reunião, tudo bem? Onde ele procura essa rua, gente? É no } \\
\text { GPS? } \\
\text { Classe: Não } \\
\text { Fo: É na lista telefônica } \\
\text { Prof PORT: Isso. Você já viu uma lista telefônica? } \\
\text { (Alguns alunos respondem que sim) } \\
\text { Prof PORT: O que que ela contém? } \\
\text { Fo: Ela tem o número de telefone, as ruas.. número de telefone das pessoas } \\
\text { Prof PORT: Das pessoas.Exato. Isso, então ela é um catálogo, um livro, que tem o nome do } \\
\text { dono da linha telefônica, endereço e o número de telefone. Ele procurou lá, não achou, que }\end{array}$ \\
\hline
\end{tabular}




\begin{tabular}{|c|c|}
\hline & $\begin{array}{l}\text { outro lugar ele procurou? } \\
\text { Fo: No mapa da cidade. } \\
\text { Prof PORT: No guia da cidade. Alguém aqui já viu o guia da cidade de São Paulo? } \\
\text { Fo: Sim } \\
\text { Prof PORT: O guia de ruas? } \\
\text { (Classe fica em silêncio) } \\
\text { Prof PORT: Não? } \\
\text { Fo: Eu sim, eu já } \\
\text { Prof PORT: Como é que ele é? } \\
\text { Fo: Ele é tipo, uma coisa assim (abre os braços e faz um quadrado no ar) } \\
\text { B: É tipo um quadrado tem todas as ruas, os nomes.. } \\
\text { Prof PORT: Não. O guia de ruas é um livro. Você pode ter visto um mapa, tá? } \\
\text { (B balança a cabeça afirmativamente) } \\
\text { Prof PORT: Ele também é um livro onde você localiza, como a gente fez no batalha naval, } \\
\text { você procura o nome da rua, você vai pra pagina e localiza, fazendo o cruzamento de linhas e } \\
\text { colunas, a rua que você está procurando. Mais sofisticado do que isso, a gente tem os } \\
\text { equipamentos eletrônicos hoje, que são guiados por satélites, que fazem esse trabalho por nós, } \\
\text { que é no caso o GPS, o google maps, o waze, tá? O princípio é o mesmo, porém ele vai fazer } \\
\text { isso guiado por um satélite e não um mapa impresso, tá? A fazer isso. Vamos ver então o que } \\
\text { que eles vão fazer com essa informação. }\end{array}$ \\
\hline $35: 57-41: 07$ & $\begin{array}{l}\text { Prof PORT: Vai Ra. (leitura) } \\
\text { (Ra continua a leitura do ponto em que C parou) } \\
\text { - Então a rua não existe? - disse seu Tomé. - O gordinho devia estar alarmado, quem sabe } \\
\text { acossado. } \\
\text { Cada um sentou no canto e ficaram pensando.Nisso entrou na sala uma moreninha bonitinha } \\
\text { de olho grande preto, pescoço fino e cabelo fino escorrido até o ombro, que era a Berenice. } \\
\text { - Sou a Berenice, vim aqui ajudar a encontrar o Bolachinha. } \\
\text { Só o Mister que a conhecia da classe; Edmundo e Pituca conheciam de ouvir o gordo contar e } \\
\text { ficaram admirados dela ser tão resplandecente assim. Pitica contou para Berenice o pé que } \\
\text { as coisas estavam e continuaram a pensar. } \\
\text { - Essa ser a única coisa que Bolachon falar? - perguntou o Mister. } \\
\text { - Não- respondeu seu Tomé. - Antes disse um nome que não era Veneta, era Palheta. } \\
\text { Toca a procurar em listas e guias a rua Palheta que também não existia. } \\
\text { - Senhor Tomé precisar fazer um esforço e contar tuda que o gorda falar desde a princípio. } \\
\text { Prof PORT: Vai S } \\
\text { (S lê o seguinte trecho) } \\
\text { Seu Tomé disse que primeiro o gordo falou um nome de rua que ele não lembrava agora bem } \\
\text { como era, só sabia que a palavra terminava com eta. O número que o gordo tinha dado no } \\
\text { começo parecia maior que 99, devia ter três números, mas seu Tomé só lembrava que } \\
\text { acabava em 9. Depois o gordo falou rua Veneta } 99 \text { e ele disse ao gordo que tinha entendido } \\
\text { antes outro nome, e o gordo explicou que estava aflito e dissera rua Palheta, mas que o certo } \\
\text { era Veneta 99. E foi só, desligou sem responder a uma pergunta que lhe fizera. } \\
\text { Prof PoRT: B. } \\
\text { (B lê o seguinte trecho) } \\
\text { - Gorda dizer que estar aflita. Senhor Tomé sentir afliçon na voz de gorda? } \\
\text { - No começo um pouco, estava sim. Mas depois firmou a voz e acalmou-se } \\
\text { - Na hora que falou da rua Veneta e corrigiu o erro. } \\
\text { - Senhor Tomé ter certeza ser o voz de gorda depois que ele firmar o voz? } \\
\text { - Noluta, era voz dele. Tenho excelente ouvido, toco piano. } \\
\end{array}$ \\
\hline
\end{tabular}




\begin{tabular}{|c|c|}
\hline & $\begin{array}{l}\text { parecidos, com mesma terminaçon de palavras e números para fazer un confuson danada no } \\
\text { cabeça do senhor Tomé. Como o senhor Tomé ser muito nervosa, o embaralhaçon ficar } \\
\text { perfeita. } \\
\text { (A própria professora continua lendo do ponto em que B parou a leitura) } \\
\text { - Nervoso eu sou, infelizmente, mas que tenho bom ouvido tenho. A voz era do gordo, do } \\
\text { princípio ao fim. } \\
\text { - Mim acreditar na sua ouvido e isto querer dizer que a bandida ser um imitador de voz de } \\
\text { altíssimo qualidade. Jonas e o gerente ir imediatamente nos estaçons de rádio e television e } \\
\text { trazer mim o ficha de todos esses camaradas que imitar o voz de cantor e de passarinhas! Dos } \\
\text { que trabalhar agora e dos que já trabalhar antes, pode ser uma imitador velha que estar } \\
\text { aposentada ou ter largado o rádio. Ir também no policia perguntar se haver bandidas } \\
\text { conhecidas com esse capacidade de remedaçon. Menina gorda correr periga de verdade, } \\
\text { estar presa por bandidas. Contar o caso para toda o polícia e avisar os jornais também. } \\
\text { Prof PORT: M. } \\
\text { (a aluna M lê) } \\
\text { Jonas e o gerente saíram. O Mister pegou a lista telefônica grossona e rasgou em cinco } \\
\text { pedaços com a facilidade de quem tira uma folha do caderninho. Deu um para Edmundo, um } \\
\text { para Pituca, um para Berenice, outro para seu Tomé e ficou com o último. }\end{array}$ \\
\hline $41: 07-42: 35$ & $\begin{array}{l}\text { Prof PORT: Então vamos entender o que ele quer fazer. Ele percebeu que tinha alguma coisa } \\
\text { errada e ele já sabe que o bandido pegou o telefone e imitou a voz do Bolacha. E aí como ele } \\
\text { vai descobrir quem é esse bandido? Aonde ele vai procurar isso? } \\
\text { Ra: Ele vai procurar no rádio porque (nesse momento passa um carrinho no corredor, ao } \\
\text { lado da sala de aula, faz muito barulho e não dá para ouvir o que a aluna falou) } \\
\text { Prof PORT: Não, eles vão procurar imitadores, né? De pessoas, de voz, ou imitadores de } \\
\text { passarinho. São pessoas que tem facilidade de ouvir o som, memorizar, o tipo, a forma e } \\
\text { reproduzir, tá? E, ao mesmo tempo, ele dividiu a lista telefônica em cinco partes e deu uma } \\
\text { pra cada um, pra que será que ele deu pras pessoas, pros meninos isso? } \\
\text { L: Pra Pituca, pro Edmundo, pra Berenice } \\
\text { Prof PORT: Pra quê? } \\
\text { Fo: Pra anotar } \\
\text { Prof PORT: Pra anotar? } \\
\text { Fo: As coisas que eles queriam } \\
L: \text { Os lugares que ele já foi e os que não } \\
\text { Prof PORT: Poderíam também estar procurando ruas que terminassem com este final de } \\
\text { palavra? } \\
\text { L: Sim, que terminavam com eta } \\
\text { Prof PORT: Isso. Bom, vamo ver se a gente consegue acabar esse capítulo pra depois a gente } \\
\text { reorganizar o que falta, tá? }\end{array}$ \\
\hline $42: 35-47: 22$ & $\begin{array}{l}\text { Prof PORT: Vai, Gi } \\
\text { (Gi prossegue a leitura) } \\
\text { - Nós ter trabalho para muitos horas. Cada um anotar todos os ruas terminadas em eta. Mim } \\
\text { ter certeza que o fábrica clandestina estar numa rua que terminar em eta e o número da casa } \\
\text { terminar em 9. Depois nós procurar, o polícia procurar, todos os casas de número final } 9 \text { em } \\
\text { todos os ruas que acabar em eta. } \\
\text { - Número acima de cem- disse Edmundo.- O número que o gordo falou primeiro tinha três } \\
\text { casas. Já simplifica um pouco. } \\
\text { Prof PORT: T } \\
\text { (o aluno lê) }\end{array}$ \\
\hline
\end{tabular}




\begin{tabular}{|c|c|}
\hline & 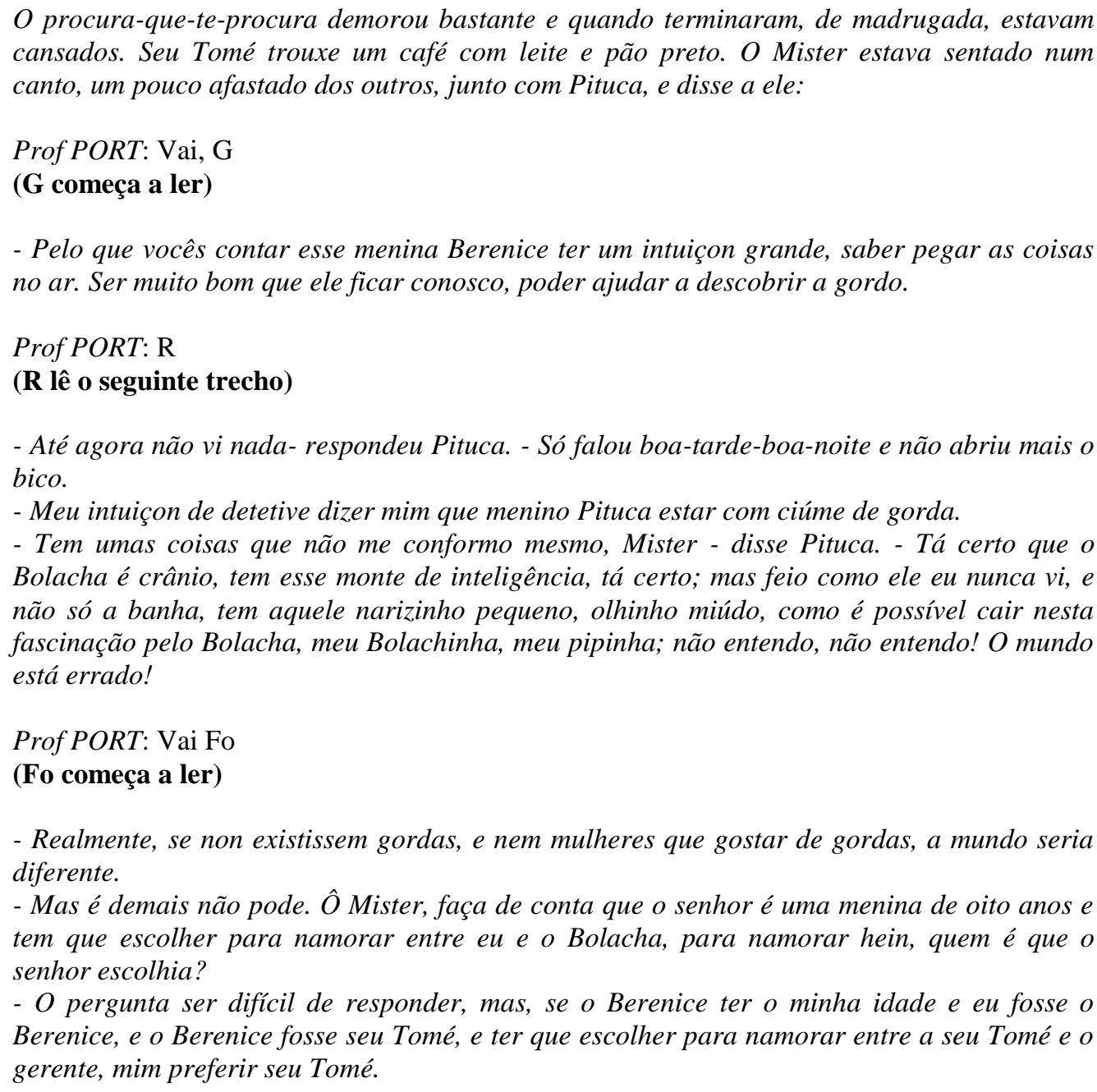 \\
\hline $47: 22-47: 37$ & $\begin{array}{l}\text { Prof PORT: Nossa que resposta, afinal de contas, ele escolheria quem? } \\
\text { Classe: Seu Tomé } \\
\text { Prof PORT: Pituca? } \\
\text { Fo: Berenice } \\
\text { Prof PORT: É, não, o seu Tomé é mais velho que o gerente ele escolheria ao menos o } \\
\text { Bolacha, não sei }\end{array}$ \\
\hline $47: 37-48: 23$ & $\begin{array}{l}\text { Prof PORT: Vai A. } \\
\text { (A lê a seguinte parte) } \\
\text { Seu Tomé serviu o café com leite e o pão preto,o Mister se espreguiçou e levantou da cadeira. } \\
\text { - Puxa o vida, nós trabalhar muito hoje; mim estar cansada. Quando o gente estar cansada, } \\
\text { uma gole de uísque ser um coisa indispensável. } \\
\text { Puxou a garrafinha e chupou um trago enorme, bem maior que os de antes, porque estava } \\
\text { cansado. E o Mister deu um urro e começou a cuspir na sala e foi na janela, abriu a janela e } \\
\text { continuou cuspindo lá fora. } \\
\text { O gerente e Jonas chegavam naquela hora e o Mister urrava e cuspia. }\end{array}$ \\
\hline $48: 23-48: 30$ & $\begin{array}{l}\text { Prof PORT: Nossa, mas ele não gostava de uísque? } \\
L: \text { Sim, mas ele bebeu muito }\end{array}$ \\
\hline
\end{tabular}




\begin{tabular}{|c|c|}
\hline & $\begin{array}{l}\text { Prof PORT: Será? } \\
\text { Ra: Não é muito } \\
\text { Prof PORT: Estranho, né? }\end{array}$ \\
\hline $48: 30-49: 23$ & $\begin{array}{l}\text { Prof PORT: Vai, F } \\
\text { (F faz a leitura deste trecho) } \\
\text { - Minha Deus do Céu, isto não ser uísque, isto ser um coisa muito ruim, isto ter gosto de non } \\
\text { saber o quê e queimar mim toda por dentro! } \\
\text { Pituca caiu no tapete rindo, rolava rindo, se esparramava e ria ria ria sem parar. } \\
\text { - Rá! Rá! Rá! Agora eu entendi! Rá! Rá! Rá! A vingança que o Bolacha inventou, o máximo! } \\
\text { Rá! Rá! Logo que o senhor saiu da cabana, eu bem vi o gordo mexendo no lampião e } \\
\text { derramando querosene dentro duma coisa. Rá! Rá! Ninguém guenta esse gordo! O senhor } \\
\text { bebeu querosene, Mister. }\end{array}$ \\
\hline $49: 23-50: 16$ & $\begin{array}{l}\text { Prof PORT: Entenderam o que aconteceu com ele? } \\
R: \text { O que é querosene? } \\
\text { Prof PORT: Querosene? } \\
\text { F: É uísque } \\
\text { Prof PORT: Quem pode explicar para ele? } \\
\text { Fo: Nem eu sei } \\
B: \text { Também não sei } \\
\text { Prof PORT: Querosene é um produto que é derivado do petróleo, não é uísque, uísque é uma } \\
\text { bebida. Querosene você usa como produto, como solvente pra tinta, como combustível pra } \\
\text { lampiões, não tem nada a ver com bebida, tá? } \\
G: \text { Então porque que ele começou a rir sem parar? } \\
\text { F: Porque ele bebeu querosene } \\
\text { Prof PORT: Quem que colocou querosene dentro da garrafinha? } \\
\text { Classe: O gordo } \\
\text { Prof PORT: O gordo, e por que que ele fez isso? } \\
\text { Ra: Vingança } \\
\text { Prof PORT: Vingança por que? } \\
C: \text { Porque ele deixou ele beber o } \\
\text { Prof PORT: Quando ele bebeu uísque pela primeira vez o que aconteceu com ele? } \\
L: \text { Ficou com soluço, a boca dele queimou e ele } \\
\text { Prof PORT: Então, culpa do Mister, né? } \\
\text { Prof PORT: Bom, vamo terminar esse pedacinho, gente? Antes que bata o sinal } \\
L: \text { Deixa eu, deixa eu } \\
\text { Prof PORT: Vai, rapidinho então }\end{array}$ \\
\hline $50: 16-51: 03$ & $\begin{array}{l}\text { (o aluno L lê) } \\
\text { Edmundo e Berenice caíram na gargalhada, e o gerente, que andava com medo do Mister, } \\
\text { depois do estrilo que levou, virou a cara de lado, para o Mister não ver, e ficou com a } \\
\text { garganta dando pulinho de boca fechada. Mas seu Tomé também ria, até o Jonas se dobrava, } \\
\text { num riso pouco disparado feito metralhadora, e o gerente abriu a boca e soltou a gargalhada. } \\
\text { O Mister ficou de pé no meio da sala de nariz torcido. } \\
\text { - Esse gorda ter cado uma. } \\
\text { Olhou para a garrafinha, destorceu o nariz e caiu na gargalhada junto com todo mundo. }\end{array}$ \\
\hline $51: 03-54: 48$ & $\begin{array}{l}\text { Prof PORT: Bom, a gente vai parar pra organizar algumas coisas. Primeiro gente, o } \\
\text { Linguagens pode levar pra casa, não precisa trazer mais. Pra amanhã eu preciso do livro e do } \\
\text { caderno pra gente finalizar. E vocês tem quantas aulas com a Silvia hoje ainda? } \\
\text { L: Com a Silvia, duas } \\
\text { Prof PORT: Eu vou pedir pra ela, se vocês toparem, pra continuar }\end{array}$ \\
\hline
\end{tabular}




\begin{tabular}{|l|l|}
\hline Classe: Sim, sim \\
Prof PORT: Então eu falo com ela, se ela não topar vocês continuam com ela, senão eu volto \\
aqui e a gente divide uma parte pra vocês lerem em casa \\
C: A Marilde também tem \\
Prof PORT: A Marilde tá finalizando coisas com vocês, não tá? \\
$\begin{array}{l}\text { L: Sim, ela tá acabando } \\
\text { (Alunos circulam pela sala, vão até o armário, mudam cadeiras de lugar, guardam livros } \\
\text { na mochila, alguns conversam entre si e outros vão falar em particular com a professora) }\end{array}$
\end{tabular}




\section{ANEXO D- TRANSCRIÇÃO LIVRE DA AULA DE ITALIANO}

\begin{tabular}{|c|c|}
\hline $\begin{array}{l}\text { Duração } \\
\text { (mm:ss) }\end{array}$ & Descrição \\
\hline $00-2: 35$ & 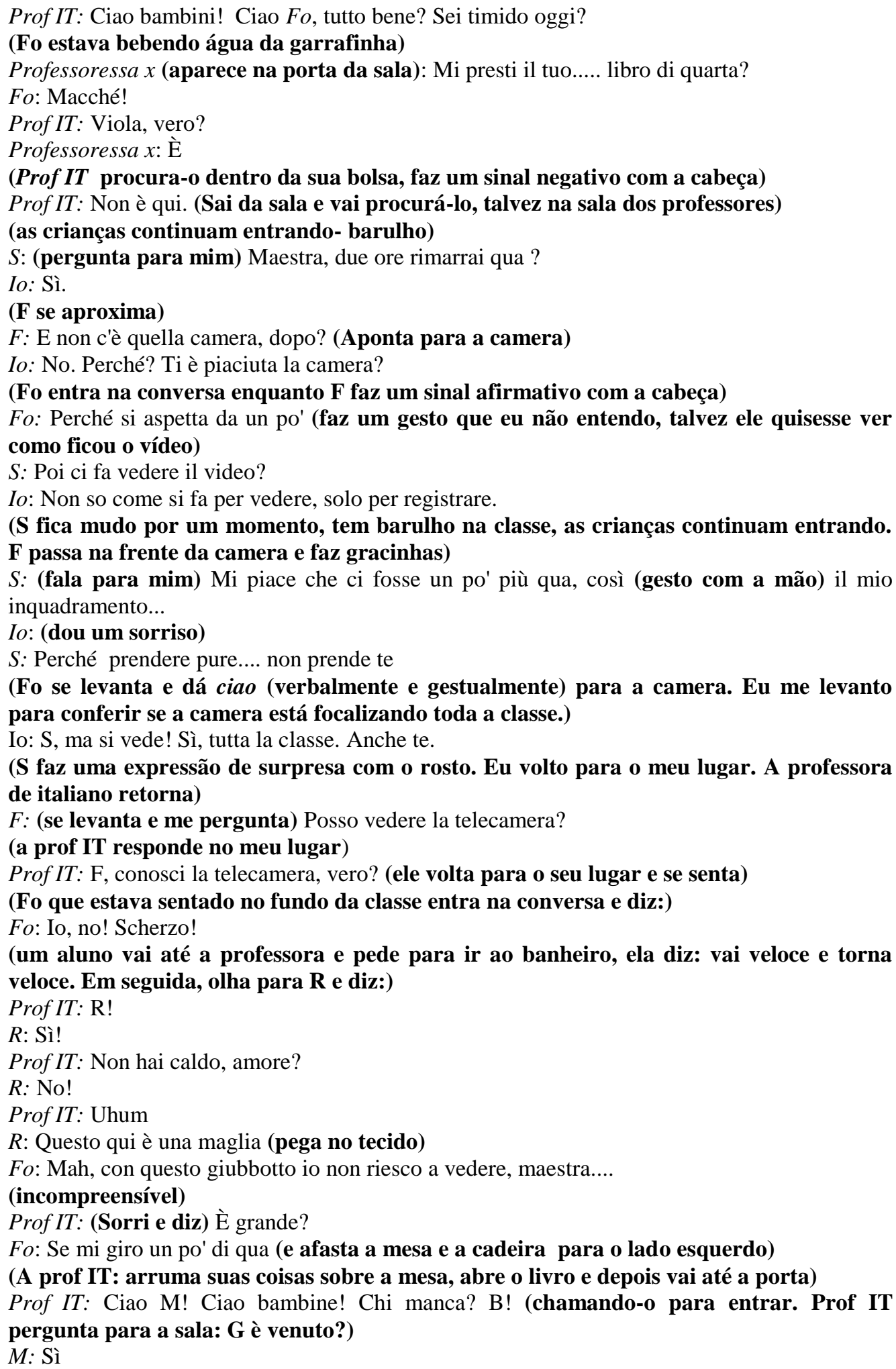 \\
\hline
\end{tabular}




\begin{tabular}{|c|c|}
\hline & $\begin{array}{l}\text { C: Sì!...È... stai venuti tutti. } \\
\text { (Ra vai até o fundo da classe e retira um pote de vidro de dentro de uma sacola que } \\
\text { estava na prateleira) } \\
\text { Prof IT:: Siete pronti per il Carroção? } \\
\text { Classe: Sì!!!! } \\
\text { Prof IT:: Avete già preparato le valigie? } \\
\text { Classe: No!!! }\end{array}$ \\
\hline $2: 35-3: 17$ & $\begin{array}{l}\text { (Ra entrega o pote de vidro para a professora) } \\
\text { L: Maestra } \\
\text { (Fo assalta o turno e fala mais alto para chamar a atenção da professora) } \\
\text { Fo: Maestra! Pure non è il baccalà, ok? È baccalà, ok? } \\
\text { Ra: Não é bacalhau! É... } \\
\text { Fo: È baccalà! } \\
\text { (Prof IT olha o pote e diz) Prof IT: Uau! Chi ha preparato? Te? } \\
\text { Ra: Mia zia } \\
\text { Prof IT: Tua zia? } \\
\text { (Fo se levanta, vai até a professora e diz) Fo:: No aspetta, dimmi se non sembra baccalà. } \\
\text { (Ra irritada altera o tom de voz e diz) Ra: Não é bacalhau! Fo } \\
\text { Fo: Ok, (pega o pote, olha para a professora e diz) ma dimmi se non sembra baccalà. } \\
\text { Prof IT: No.Non sembra baccalà. } \\
\text { (Fo vira-se e volta para o seu lugar. Ra olha para Fo, aponta o dedo para ele e diz ) } \\
\text { Ra: Você parece um bacalhau! } \\
\text { Prof IT: Vuoi prendere in giro Ra } \\
\text { Fo: No! } \\
\text { Prof IT: Tu vuoi prendere Ra in giro, sì. Ti conosco. } \\
\text { (Fo fala algo incompreensivel) }\end{array}$ \\
\hline $3: 17-5: 12$ & $\begin{array}{l}\text { C: Maestra! } \\
\text { Prof IT: Oi } \\
\text { C: Ieri.. é... no, no. Dieci. } \\
\text { Prof IT: Non ho capito niente. Ripeti! } \\
\text { C: Ieri, alle 10, la mia mamma è cominciata a fare, a prendere } \\
\text { Prof IT: Ha cominciato } \\
\text { C: Ha cominciato a fare..ãh... uma sacola con le mie... con i miei vestiti per il Carroção, } \\
\text { perché la mia mamma e la mia zia fanno i.... mettono i } \\
\text { Prof IT:: Nomi } \\
\text { C: Ė.. i nomi } \\
\text { Prof IT: Allora, una cosa importante é portare una o molte bustine, perché molte volte, (C } \\
\text { interrompe: Cos'è bustine, mas a professora prossegue) per esempio, c'è il fiume, la } \\
\text { piscina, tipo questo si bagna } \\
\text { S: Come bustine? } \\
\text { Prof IT: A busta (faz um gesto com a mão) per mettere dentro delle cose. } \\
\text { (C fala algo incompreensível e a professora diz ok) } \\
\text { Prof IT: Un altro punto. } \\
\text { M: Maestra (não consegue formular a frase, se atrapalha) } \\
\text { Prof IT: Di nuovo, vai! } \\
\text { M: La scuola ha mandato un' e-mail alla classe per le cose che ci devono portare } \\
\text { Prof IT: Sì } \\
\text { M: A me non l'hanno mandata } \\
\text { Prof IT: Allora va a chiamare (T interrompe e pega o turno) } \\
T: \text { Io ho preso la scheda. Io ho preso la scheda (repete para reformular e continuar) delle } \\
\text { cose che ti devo a portare } \\
\text { Fo: Io ce l'ho e faccio i rischi così (e faz com o dedo o sinal de ticar) delle cose che c'ho } \\
\text { Prof IT: Due scarpe da tennis, vero? } \\
\text { Fo: Una.. una vecchia }\end{array}$ \\
\hline
\end{tabular}




\begin{tabular}{|c|c|}
\hline & $\begin{array}{l}\text { Prof IT: Ma molto vecchia! Molto vecchia (fala mais alto e repete para dar ênfase na } \\
\text { informação, muitos alunos falam ao mesmo tempo) } \\
\text { Prof IT: Perché la mia, quella che ho usato l'anno scorso poi non l'ho potuta più usare } \\
\text { Ra: Sei andata l' anno scorso? } \\
\text { (A professora faz um gesto afirmativo com a cabeça) } \\
\text { Fo: È appunto ti lascia in piede. } \\
\text { (A professora sorri) } \\
\text { Prof IT: Sì. Che altro? } \\
\text { F: Perché non va di nuovo, Prof IT? } \\
\text { C: Deve portare sette magliette } \\
\text { Fo: Aspetta voglio chiedere una cosa a maestra }\end{array}$ \\
\hline $5: 12-6: 06$ & $\begin{array}{l}\text { Fo: Sei palmeiras? } \\
\text { Prof IT: Sì } \\
\text { Fo: E non dici niente? } \\
\text { (a classe comemora- barulho. A professora levanta as mãos) } \\
\text { Prof IT: Abbiamo vinto. Ce l'abbiamo fatta, almeno questa volta, no? } \\
\text { R: Che cosa? } \\
\text { Prof IT: Palmeiras, no? } \\
\text { (as crianças falam algo juntas- incompreensível) } \\
\text { Prof IT: Chi l'ha vista? Chi ha visto la partita? } \\
\text { (B se levanta e em voz alta diz: Ioooo!) } \\
\text { Prof IT: Tu sei palmeirense? } \\
B: \text { Sì (risos) } \\
\text { Prof IT: Ah.. non sapevo } \\
\text { C: Quasi tutta la classe } \\
T: \text { Io sono palmeirense! } \\
\text { Prof IT: E chi non lo è? } \\
\text { Ra: Io sono! } \\
\text { (R e S levantam a mão) } \\
\text { Prof IT: S } \\
\text { S: Juventus. } \\
\text { Prof IT: No. Ok, ma in Brasile? Niente? } \\
\text { S: No. } \\
\text { Prof IT: R e te? } \\
\text { R: Não, eu não sou nada, ma } \\
\text { (Fo interrompe e fala simultaneamente enquanto a professora e R continuam } \\
\text { conversando) } \\
\text { Fo: AS Roma. Associazione Sportiva Roma (e mostra seu estojo do time) } \\
\text { Prof IT: Non ti piace il calcio? } \\
R: \text { No. } \\
\text { (A professora olha para o Fo, vê o estojo e diz) } \\
\text { Prof IT: Ah, ok! Va bene }\end{array}$ \\
\hline 6:06- 13:10 & $\begin{array}{l}\text { Prof IT: Un altro dubbio per il Carroção o no? Tutto a posto? } \\
\text { (C levanta a mão e diz: Io! Mas T rouba o turno) } \\
\text { T: Io la ficha medica io non l'ho. } \\
\text { Prof IT: Non l'hai consegnata? } \\
T: \text { Non ancora, perché la mia mamma è in Italia e mio padre me lo sono dimenticato di dirlo } \\
\text { che deve firmare per domani. } \\
\text { Prof IT: Aspetta! Quando torna la tua mamma? } \\
T \text { : Torna venerdì di notte } \\
\text { Prof IT: E avrà tempo di compilare i lati ? } \\
T: \text { No. Credo di no, ma la posso chiedere a mio padre, anche se } \\
\text { Prof IT: E perché non ha ancora fatto? } \\
T: \text { Lui non è uno molto organizzato, sai? }\end{array}$ \\
\hline
\end{tabular}




\section{(A professora sorri)}

A: Mia mamma l'ha mandato in segreteria

Prof IT: Hã...L'hai già consegnato?

(A faz um gesto afirmativo com a cabeça)

Prof IT: R, tu che la dovevi consegnare, l'hai fatto?

$R$ : In verità, non so se è arrivata ma... la mia mamma ha mandato per e-mail

Prof IT: Ok

$L$ : Maestra, io stato il primo a consegnare.

Prof IT: Ok. F

$F$ : Sim, eu coloquei lá (e faz um gesto com a mão)

Prof IT: Ok.

(Ra levanta a mão)

Prof IT: Ra

(B, L e C estão conversando em voz alta)

Prof IT: Aspetta B, devo sentire Ra. B, aspetta un attimo.

$\mathrm{Ra}$ : Che ora che deve arrivare?

( $L$ assalta o turno e responde às 6:30- em português)

Prof IT: L'autobus parte alle 7:00. Dovete essere qua alle 6.30.

Fo: Nossa maestra! Ma meno qui alle 6:00. Oggi alle 7:20 ho fatto fatica.

Prof IT: Ma è per il Carroção, non è per fare la lezione.

(crianças conversam juntas ao mesmo tempo- barulho. A professora chama atenção da classe dizendo: Oh! $M$ ha alzato la mano, mas $M$ esquece o que ia dizer)

Prof IT: Alzi la mano e...

$M$ : Maestra

Prof IT: C, sentiamo (pedido indireto para ela ficar quieta)

$M$ : Io ho guardato la ficha medica e non so (incompreensível)

Fo: Che?

Prof IT: Perché non l'hai consegnata in segreteria?

$M$ : È che me l'hanno chiesta l'altro giorno e...

Prof IT: E niente, hai dimenticato?

$M$ : Ѐ... (e faz um gesto afirmativo com a cabeça)

Fo: Ma ce l'hai a casa?

$M$ : No, qua

Fo: Allora, dagliela

Prof IT: No, va bene, l'importante

Fo: Ma ce l'ha qua

Prof IT: Allora, alla fine della lezione la puoi portare la giù, va bene?

(M faz um gesto afirmativo com a cabeça. $C$ levanta a mão)

Prof IT: C, dimmi

$C$ : Sai quando dobbiamo arrivare. Puoi venire

Prof IT: Non ho sentito. Sai?

$C$ : Quando.. è.. Deve venire con uniforme?

Prof IT: È, quello che ha proprio domandato B

Fo: Io pure volevo chiederlo

Prof IT: Mi ha appena domandato la stessa cosa e gliel'ho e gli ho detto di no

(Fo comemora)

L: Cosa?

Prof IT: Ma tu, amore, la maglietta della scuola non la porti, vero?

Fo: Sì! È perché è troppo sporca, troppa cosa di arte e poi busso di acqua sanitaria perché mia..

(T assalta o turno de Fo)

$T$ : Io mai la porto, la maglietta della scuola.

Prof IT: Esatto. T,Gi, F, S

Fo: Io! Mia madre si è sbagliata

Prof IT: A. Porti la maglietta della scuola? (se aproxima da aluna para conferir) No!

$T$ : Per me, io .... a me non piaciuto la maglietta

(muitas crianças começam a falar ao mesmo tempo- incompreensível)

Prof IT: Voi siete obbligati a portarla.

Fo: No. 


\begin{tabular}{|c|}
\hline 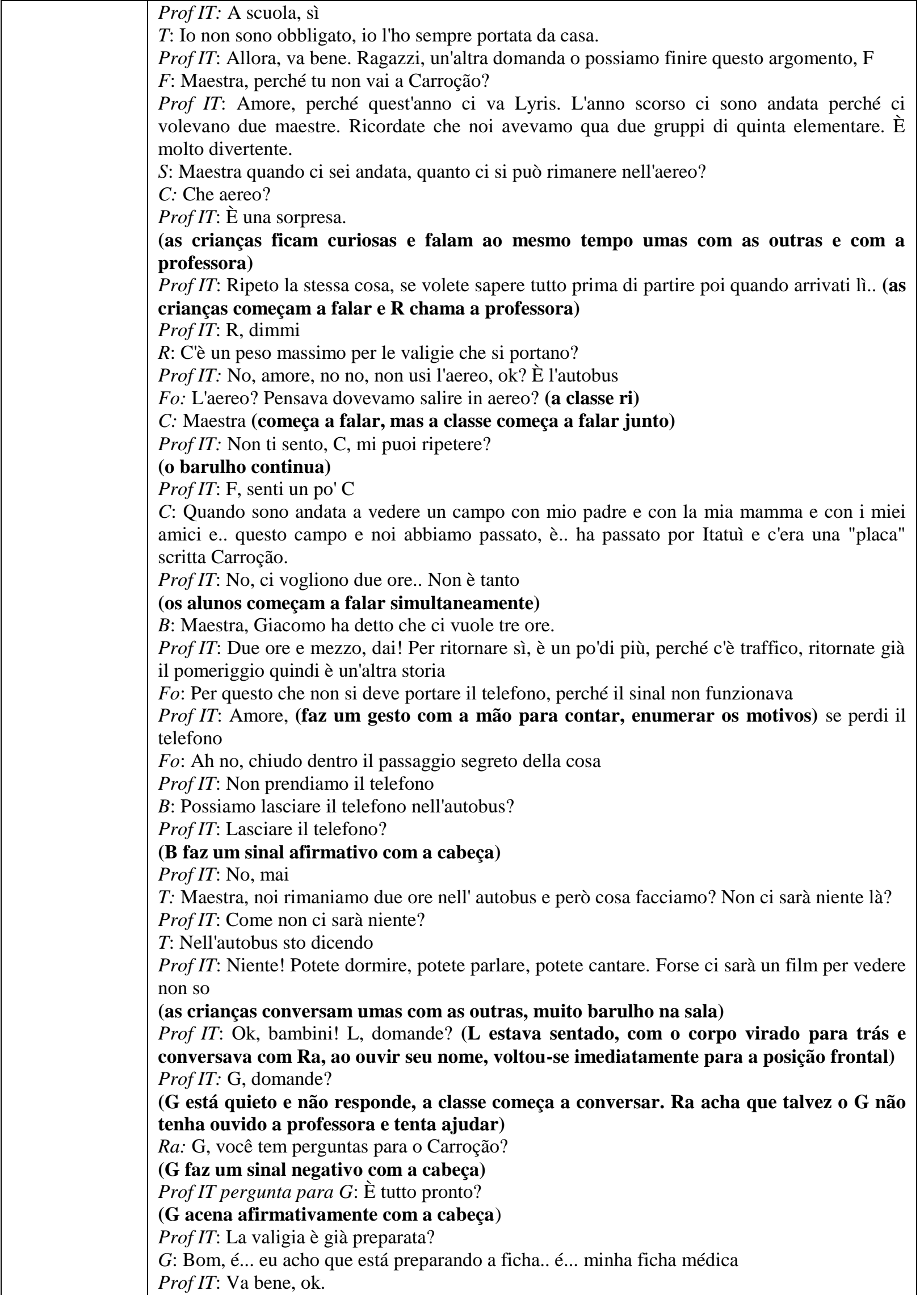 \\
\hline
\end{tabular}




\begin{tabular}{|c|c|}
\hline $13: 10-16: 06$ & 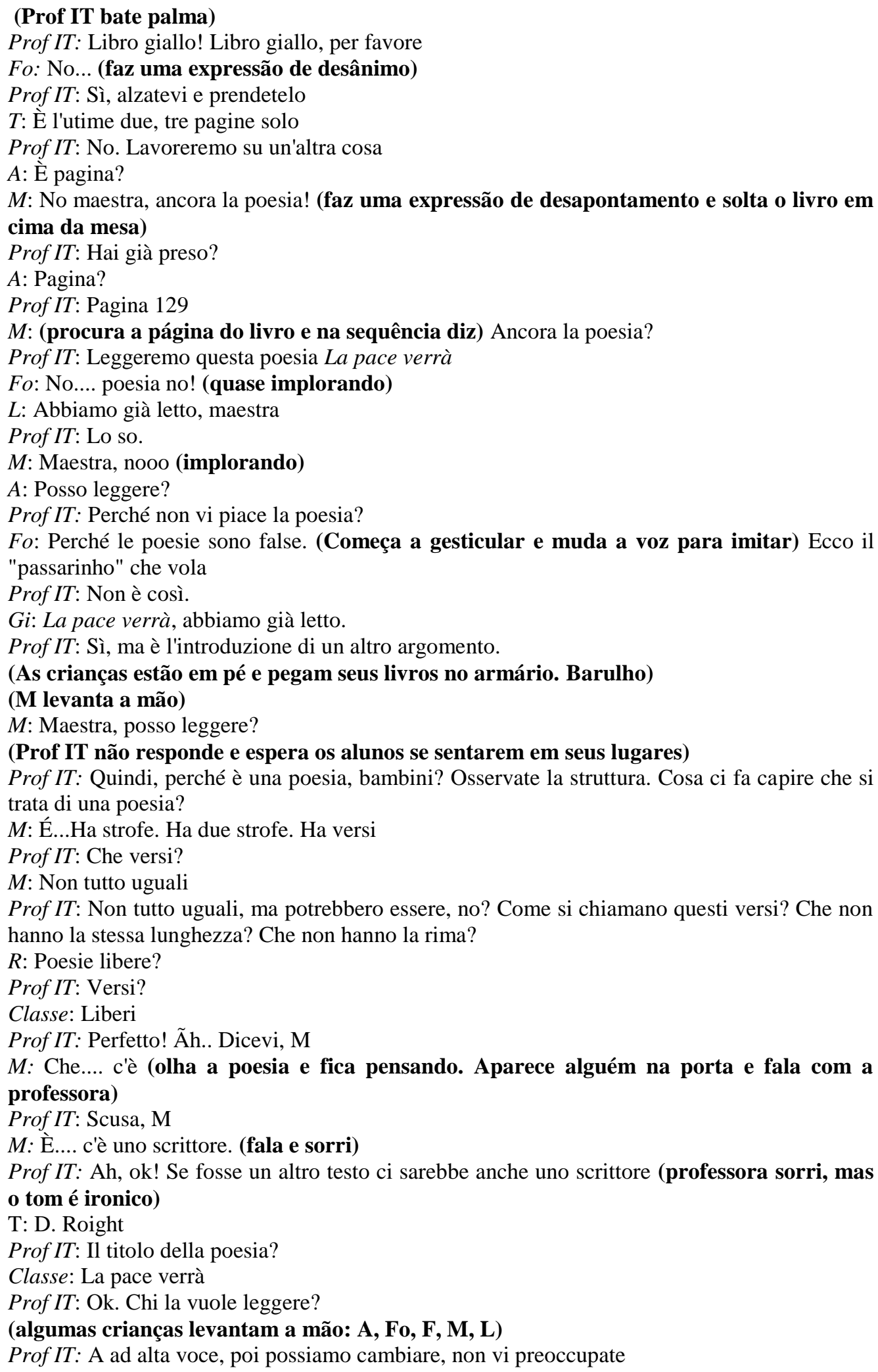 \\
\hline $16: 06-16: 32$ & $\begin{array}{l}\text { (A aluna A lê a poesia) } \\
\text { La pace verrà }\end{array}$ \\
\hline
\end{tabular}




\begin{tabular}{|c|c|}
\hline & $\begin{array}{l}\text { La pace verrà sulla terra } \\
\text { non prima che ogni bambino } \\
\text { possa saziare ogni giorno la sua fame } \\
\text { affrontare al caldo il vento dell'inverno, } \\
\text { studiare la lezione con l'animo tranquillo. } \\
\text { Quando sarà liberato dalla fame, } \\
\text { dalla paura e dal bisogno, } \\
\text { qualunque sia il suo cuore, } \\
\text { la sua razza o la sua fede, } \\
\text { alzerà la testa e sorriderà al cielo. }\end{array}$ \\
\hline $16: 32-16: 40$ & $\begin{array}{l}\text { Prof IT: Ok. Un'altra persona vuole leggere? } \\
\text { (Sete alunos- Ra, S, B, C, L, Fo e A- levantam a mão e a professora se surpreende) } \\
\text { Prof IT: Nossa! Ok! Facciamo così, facciamo quella colonna lì. S, alta voce, la voglia di } \\
\text { leggere, per favore }\end{array}$ \\
\hline $16: 40-17: 25$ & $\begin{array}{l}\text { (S lê a poesia) } \\
\text { La pace verrà } \\
\text { La pace verrà sulla terra } \\
\text { non prima che ogni bambino } \\
\text { possa saziare ogni giorno la sua fame } \\
\text { affrontare al caldo il vento dell'inverno, } \\
\text { studiare la lezione con l'animo tranquillo. } \\
\text { Quando sarà liberato dalla fame, } \\
\text { dalla paura e dal bisogno, } \\
\text { qualunque sia il suo cuore, } \\
\text { la sua razza o la sua fede, } \\
\text { alzerà la testa e sorriderà al cielo. }\end{array}$ \\
\hline $17: 25-17: 52$ & $\begin{array}{l}\text { (Durante a leitura da poesia a aluna } \mathbf{C} \text { faz uma pergunta: cos'è fede? } \mathbf{S} \text { continua a leitura } \\
\text { e ao final a professora retoma a pergunta da aluna) } \\
\text { Prof IT: Cos'è fede? Chi può spiegare a C cos'è fede? Non è la traduzione } \\
\text { B: Ė una... A cosa credi } \\
\text { L: Religione } \\
\text { Prof IT: Fede e religione sono cose diverse. Tu puoi avere una religione, però non credere. } \\
\text { S: Credere in qualcosa. } \\
\text { Prof IT: Sì. Credere in qualcosa. Avere fede è credere in qualcosa. Può essere una persona, } \\
\text { può essere un Dio, può essere (deixou suspenso). Ra }\end{array}$ \\
\hline $17: 52-22: 21$ & $\begin{array}{l}\text { (A aluna Ra começa a leitura) } \\
\text { La pace verrà } \\
\text { La pace verrà sulla terra } \\
\text { non prima che ogni bambino } \\
\text { possa saziare ogni giorno la sua fame } \\
\text { affrontare al caldo il vento dell'inverno, } \\
\text { studiare la lezione con l'animo tranquillo. } \\
\text { Quando sarà liberato dalla fame, }\end{array}$ \\
\hline
\end{tabular}


dalla paura e dal bisogno,

qualunque sia il suo cuore,

la sua razza o la sua fede,

alzerà la testa e sorriderà al cielo.

Prof IT: B, tocca a te

(o aluno $B$ inicia a leitura)

La pace verrà

La pace verrà sulla terra

non prima che ogni bambino

possa saziare ogni giorno la sua fame

affrontare al caldo il vento dell'inverno,

studiare la lezione con l'animo tranquillo.

Quando sarà liberato dalla fame,

dalla paura e dal bisogno,

qualunque sia il suo cuore,

la sua razza o la sua fede,

alzerà la testa e sorriderà al cielo.

Prof IT: L. Dovete imparla a memoria, no?

$M:$ O que?

Prof IT: Dopo aver letto cinque volte, sei volte

(Fo assalta o turno)

Fo: Infatti io ho imparato

(C levanta a mão e diz)

C: Io voglio leggere

( $\mathrm{L}$ começa a leitura)

La pace verrà

La pace verrà sulla terra

non prima che ogni bambino

possa saziare ogni giorno la sua fame

affrontare al caldo il vento dell'inverno,

studiare la lezione con l'animo tranquillo.

Quando sarà liberato dalla fame,

dalla paura e dal bisogno,

qualunque sia il suo cuore.

la sua razza o la sua fede,

alzerà la testa e sorriderà al cielo.

Prof IT: Fo

(o aluno Fo faz a leitura)

La pace verrà

La pace verrà sulla terra

non prima che ogni bambino

possa saziare ogni giorno la sua fame

affrontare al caldo il vento dell'inverno,

studiare la lezione con l'animo tranquillo.

Quando sarà liberato dalla fame,

dalla paura e dal bisogno, 


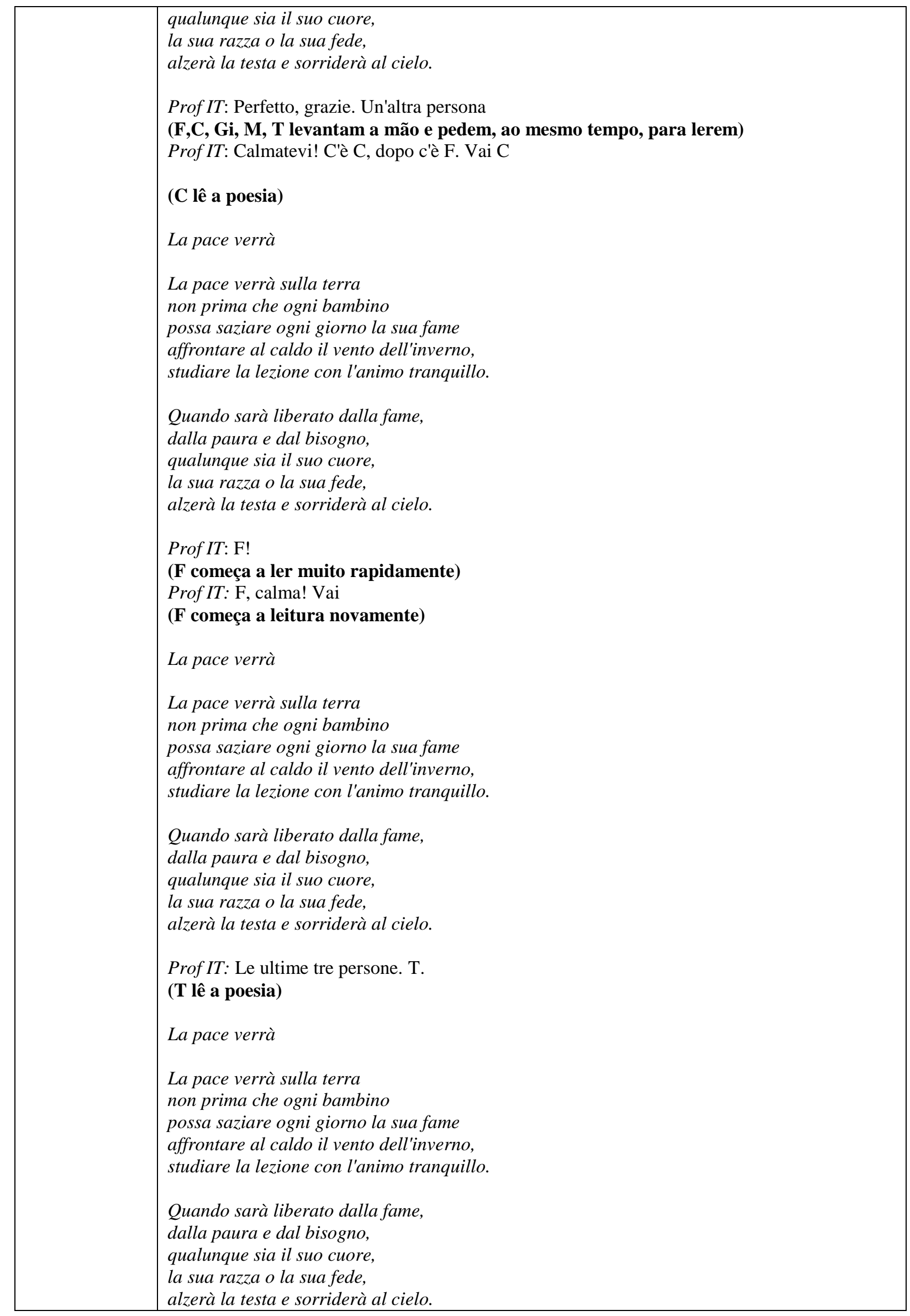


Prof IT: M, tocca a te

(a aluna $M$ lê a poesia)

La pace verrà

La pace verrà sulla terra

non prima che ogni bambino

possa saziare ogni giorno la sua fame

affrontare al caldo il vento dell'inverno,

studiare la lezione con l'animo tranquillo.

Quando sarà liberato dalla fame,

dalla paura e dal bisogno,

qualunque sia il suo cuore,

la sua razza o la sua fede,

alzerà la testa e sorriderà al cielo.

Prof IT:Ok.Gi!

(o aluno Gi realiza a leitura da poesia)

La pace verrà

La pace verrà sulla terra

non prima che ogni bambino

possa saziare ogni giorno la sua fame

affrontare al caldo il vento dell'inverno,

studiare la lezione con l'animo tranquillo.

Quando sarà liberato dalla fame,

dalla paura e dal bisogno,

qualunque sia il suo cuore

la sua razza o la sua fede,

alzerà la testa e sorriderà al cielo.

$22: 21-25: 24$

Prof IT: Ringrazio a tutti voi

$L$ : Sarà la decima volta che leggeremo questo

Prof IT: È. Bambini, in realtà questo, la stessa poesia l'ha abbiamo letta alcuni giorni fa e anche abbiamo fatto la discussione di questo testo, ma in realtà, adesso, voglio la vostra risposta. Tre diritti che hanno i bambini e che possiamo ricavare da questo, da questa poesia, che possiamo, dovete trovare questi tre diritti nella poesia letta

Fo: Io ho uno

Prof IT: Ne hai uno?

(M levanta a mão)

$M$ : Maestra, io ne ho due

(C assalta o turno)

$C$ : Studiare

Prof IT: Il diritto all'istruzione

M: Mangiare, studiare e...

Prof IT: Ok. Diritto all'istruzione, diritto al cibo, no? Ãh

L: Essere liberato

Prof IT: Liberato da cosa?

(S levanta a mão)

S: Maestra, posso?

(A professora acena afirmativamente com a cabeça)

$S$ : Essere rispettato nel senzo, non è... non è... rispettarlo sia del colore è..

Prof IT: Non ho capito, S. Essere rispettato 


\begin{tabular}{|c|c|}
\hline & 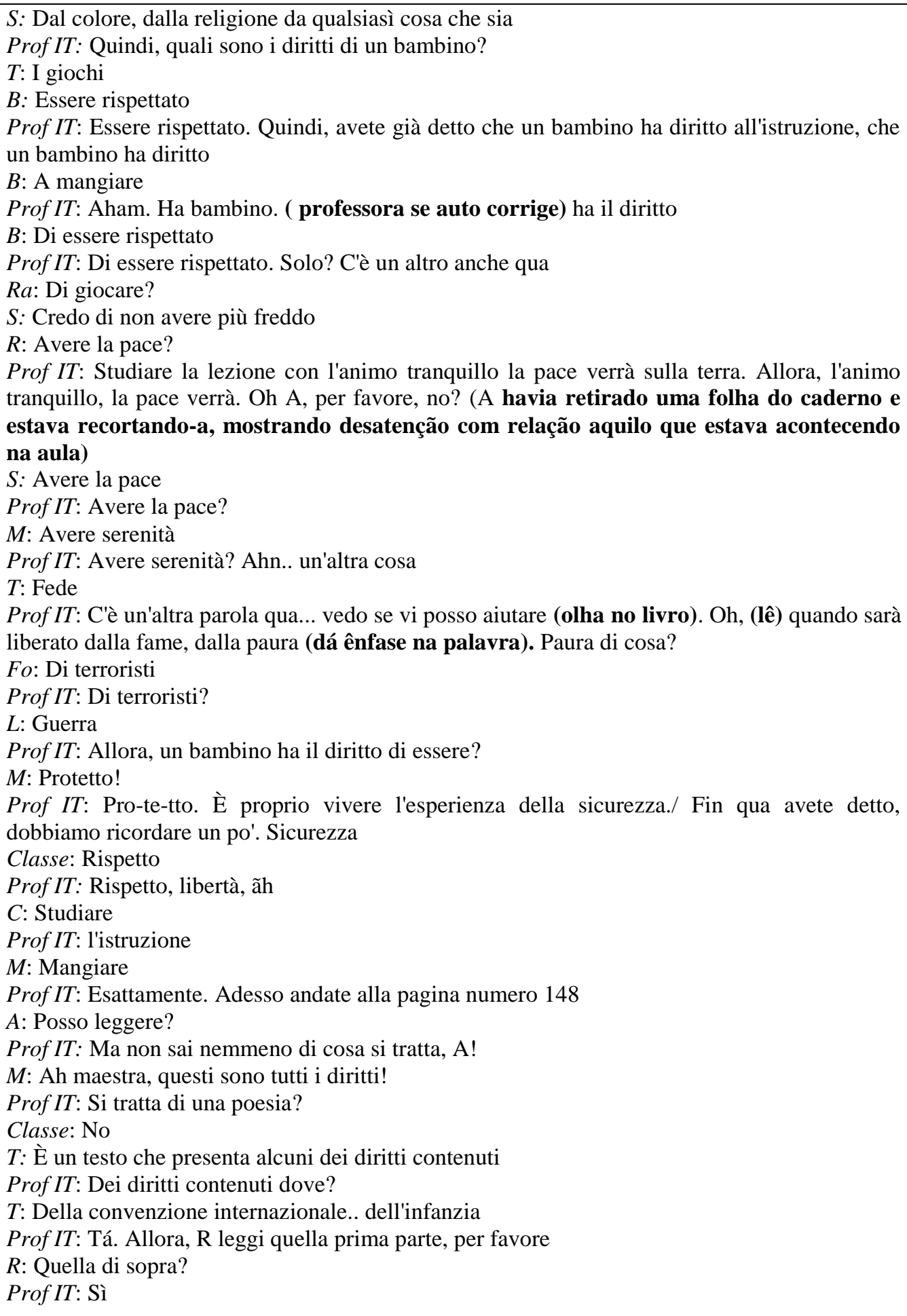 \\
\hline $26: 09-26: 34$ & $\begin{array}{l}\text { (O aluno R lê) } \\
\text { Questo testo presenta alcuni dei diritti contenuti nella Convenzione internazionale sui Diritti } \\
\text { dell'infanzia approvata nel } 1989 \text { dall'Assemblea Generale delle Nazione Unite (ONU) }\end{array}$ \\
\hline $26: 34-29: 06$ & $\begin{array}{l}\text { Prof IT: È... Quindi, di cosa tratta questo testo qua? } \\
\text { M: Dei diritti che... }\end{array}$ \\
\hline
\end{tabular}




\begin{tabular}{|c|c|}
\hline & 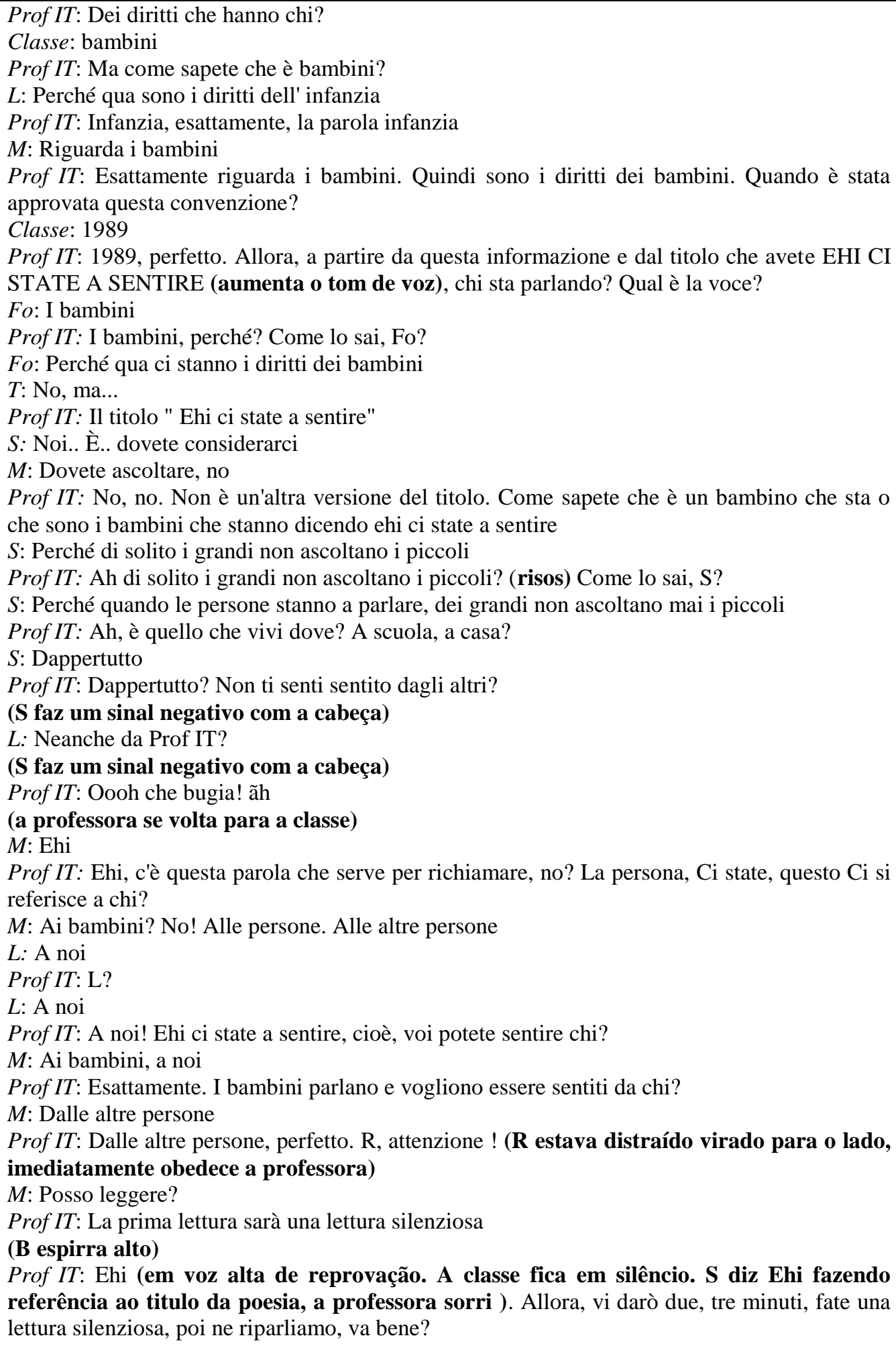 \\
\hline 29:06- 30:30 & (A professora pede para os alunos fazerem uma leitura silenciosa do texto.) \\
\hline $30: 30-34: 20$ & $\begin{array}{l}\text { M: Finito } \\
\text { (A olha para ela com cara de espanto) } \\
\text { Prof IT: Ok }\end{array}$ \\
\hline
\end{tabular}




\begin{tabular}{|c|c|}
\hline & 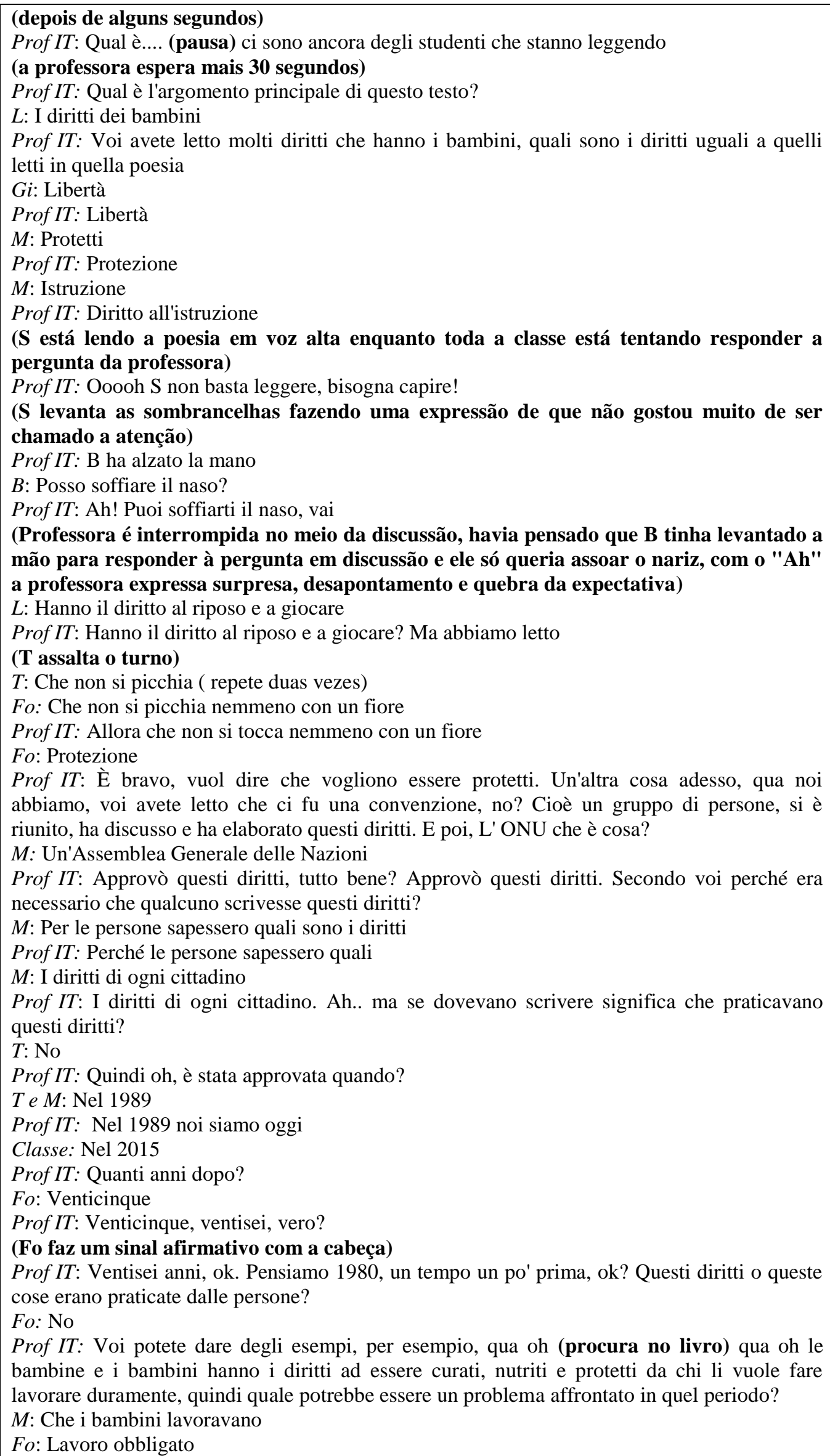 \\
\hline
\end{tabular}




\begin{tabular}{|c|c|}
\hline & $\begin{array}{l}\text { Prof IT: Ãh? } \\
\text { Fo: Lavoro obbligato } \\
\text { Prof IT: Lavoro obbligato... Un altro problema } \\
\text { M: Che c'erano guerre } \\
\text { (Fo assalta o turno) } \\
\text { Fo: Violenze! Violenze contro } \\
\text { (L assalta o turno) } \\
\text { L: C'era differenza contro le razze } \\
\text { Prof IT: E anche contro i bambini che appartenevano ad una razza diversa, no? Da quella che } \\
\text { dominava diciamo così, ok. Quindi adesso rifaremo la lettura ogni punto } \\
\text { Fo: Maestra, maestra! } \\
\text { Prof IT: Âh } \\
\text { Fo: Quella cosa che i bambini che le bambine e i bambini non si toccano neanche con un fiore } \\
\text { (incompreensível) le bambine } \\
\text { Prof IT: Uhumm, vediamo } \\
\text { Fo: È vero, è così } \\
\text { Prof IT: Gi, leggi il primo punto, per favore }\end{array}$ \\
\hline $34: 20-35: 54$ & $\begin{array}{l}\text { (Gi começa a leitura) } \\
\text { Le bambine e i bambini non si toccano neanche con un fiore } \\
\text { Prof IT: Cosa vuol dire? } \\
\text { (Fo assalta o turno) } \\
\text { Fo: Che devono essere protetti e non ci si può (pausa) } \\
\text { (M completa o raciocício deixado em suspenso) } \\
\text { M: Che non si devono far male } \\
\text { Prof IT: Che non si devono far male? Allora io non posso prendere un fiore e fare così? (faz } \\
\text { um gesto come se fosse bater na A com uma flor) } \\
\text { Fo: No! } \\
\text { Prof IT: Quindi è un linguaggio letterale? } \\
T: \text { È un sinonimo } \\
\text { M: Una metafora } \\
\text { Prof IT: Una metafora, ok e cosa vuol dire T non essere toccato con un fiore? } \\
T: \text { Che c'è.. Deve essere protetto che non si picchia. Quando uno dice la bambina non si } \\
\text { picchia con un fiore perché tutti lo dicono } \\
\text { Prof IT: Ma solo le bambine? } \\
T: \text { No! Anche i maschi } \\
\text { Prof IT: Un adulto può picchiare un bambino uomo ma non può picchiare } \\
T: \text { Nessuno dei due, per questo che io non ci credo a questo, io non ci credo a questo solo le } \\
\text { bambine, anche i maschi } \\
\text { Prof IT: Anche i maschi, ma significa che in quel momento, in quel momento esisteva } \\
\text { l'abitudine di } \\
B: \text { Picchiare } \\
\text { Prof IT: Picchiare } \\
M: \text { Maestra, adesso gli adulti non possono nemmeno toccare nei bambini e né nelle bambine } \\
\text { Prof IT: Esattamente. Quindi voi trovate importante questa legge o questo diritto? } \\
R: \text { Sì } \\
\text { (C levanta a mão) } \\
\text { Prof IT: C } \\
\text { C: C'è.. dici.. parlano che un bambino.. si picchiano un bambino è covarde } \\
\text { Prof IT: Va bene, è un vigliacco, ok }\end{array}$ \\
\hline $35: 54-39: 20$ & $\begin{array}{l}\text { Prof IT: Poi, un altro punto, M! } \\
\text { (M lê) } \\
\text { Le bambine e i bambini hanno diritto alla vita e alla libertà }\end{array}$ \\
\hline
\end{tabular}




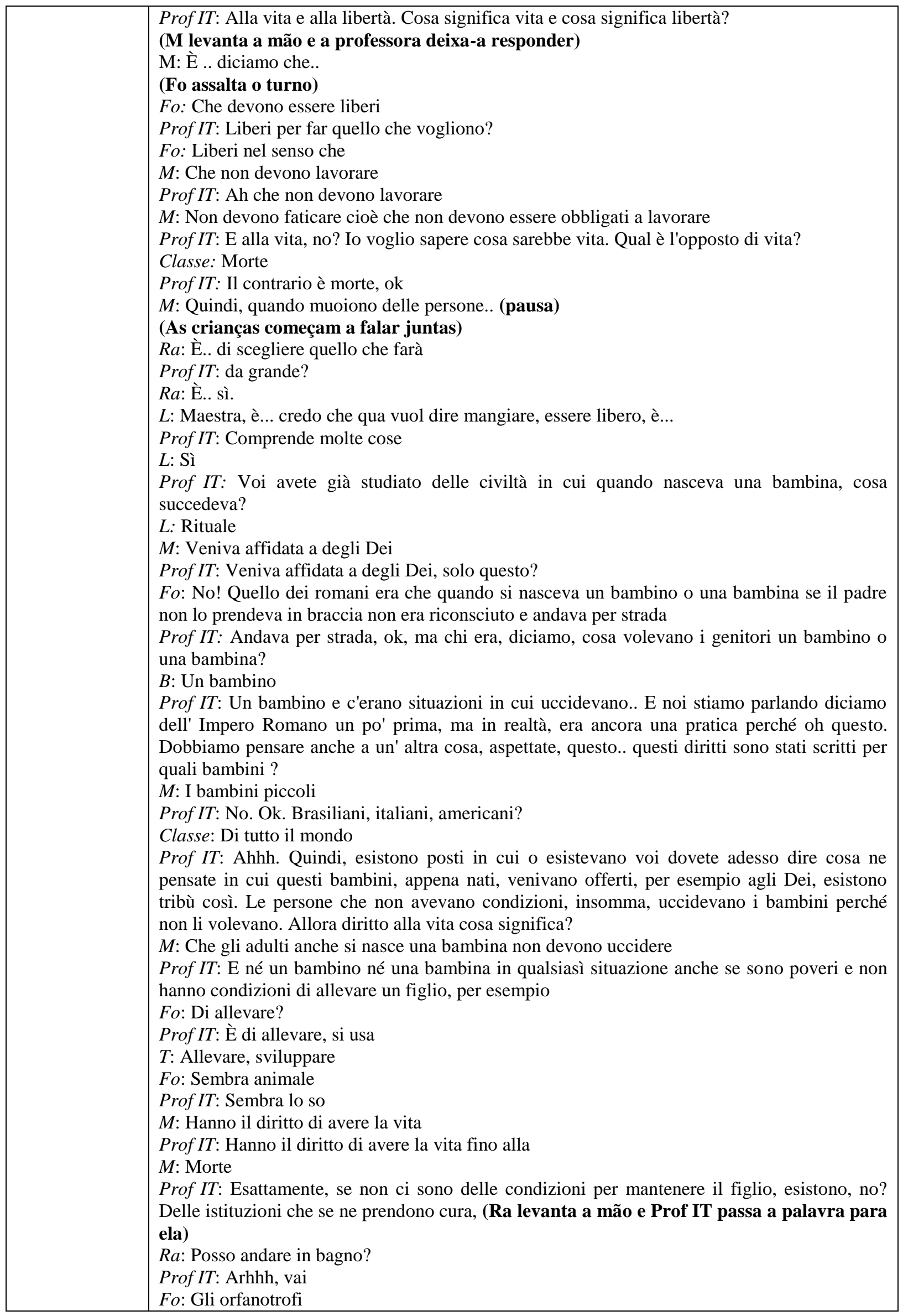


Prof IT: Poi, un altro punto T, tocca a te

(T lê)

Le bambine e i bambini hanno diritto a essere ascoltati

Prof IT: Ascoltati. Era proprio quello che diceva S, vero, S ?

( $\mathrm{S}$ faz um gesto afirmativo com a cabeça)

Prof IT: Ma non si sente ascoltato, quando ti sentiresti ascoltato dagli altri, S?

$S:$ Così

Prof IT: Così, come? Ma io ti sento, se vieni qua da me e mi dici: Maestra, posso andare in bagno? Ti dico di sì, allora

Fo: No! ascoltato nel senso, non nel senso di ascoltare, ti ascoltano pure, ma non..

$T$ : Ti credono

Fo: Uno non ti credi o non (pausa)

Prof IT: Non dà il valore giusto

Fo: È! Non dà il valore a quello che dici

Prof IT: Ah

(M estava com a mão levantada e a professora passa a palavra para ela)

$M$ : Tipo quando tu vorresti dire una cosa agli adulti pensano che è..

Fo: Che sia una schiochezza

$M$ : ̇̀ che sia una schiochezza

Prof IT: A che ne dici, amore?

(A faz um gesto com os ombros para expressar um "não sei")

Prof IT: Ti senti ascoltata o no? Puoi chiudere (A desenhava no caderno e a professora pede para ela guardar o mesmo e prestar atenção na aula)

Prof IT: Sì, no? Delle volte?

(A está sem graça, parece muito tímida e sorri, passa a mão no rosto e diz)

A: Sì

Prof IT: C'è già stata una situazione in cui non ti sei sentita?

A: Sì

$T:$ Maestra

Prof IT: Ãh

$T$ : Come c'è nel modo che le persone dicono no! Che bugiardo, come Gianluca che dice che ha gioco chiamato (incompreensível)

(Prof IT interrompe para chamar a atenção de $\mathrm{F}$ que estava virado para trás e conversava com $\mathbf{L}$ )

Prof IT: F!

( $F$ vira-se para frente. $T$ continua falando)

$T$ : Allora io avevo detto a un amico, a uno della quarta, e lui ha detto che mentira quello dici a tutti che è ricco

(a professora ignora o comentário)

Prof IT: F, pensi, cosa senti, gli adulti ti sentono? Ti ascoltano? Secondo te

$F$ : Ë.... (pensando)

$B$ : Secondo me alle volte

Prof IT: Alle volte...

T: A volte! (fazendo uma correção gramatical)

Fo: Anche alle volte

Prof IT: B, cosa vorresti? Essere più sentito, più ascoltato dagli altri?

(B faz um sinal afirmativo com a cabeça)

(C e M estão com os braços levantados)

Prof IT: Prossimo, M vai, cosa?

$M$ : Maestra, io mi sento ascoltata alle volte

Prof IT: Alle volte

$B$ : Viu? T, T alle volte

$T$ : No, a volte (aumenta o tom de voz)

Fo: A volte e alle volte, però alle volte è più

$T$ : Macché alle volte

Fo: Sì può dire, si dice!

Prof IT: Fo! Si dice. Fo,dai ! 


\begin{tabular}{|c|c|}
\hline $41: 53-42: 56$ & $\begin{array}{l}\text { (Fo lê) } \\
\text { Le bambine e i bambini, di ogni razza, religione, sesso, poveri o ricchi che siano, hanno tutti } \\
\text { gli stessi diritti come "cittadini in erba", cioè come piccoli cittadini che cresceranno } \\
\text { (M levanta a mão) } \\
\text { Prof IT: Oi M } \\
\text { M: Maestra questo diritto vuol dire che anche se sono poveri, ricchi non.. è.... che hanno è.... } \\
\text { di ogni razza, religione e quello che è, devono crescere fino alla fine } \\
\text { Prof IT: E... non importa la razza, non importa la religione, non importa che cosa } \\
\text { M: Il sesso } \\
\text { Prof IT: Il sesso, tutti i bambini hanno gli stessi diritti. Ah questo diritto di essere ascoltato } \\
\text { tocca solo a un ricco, tocca solo a un bianco, tocca solo no! I diritti sono uguali per tutti i } \\
\text { bambini } \\
\text { M: Non importa il sesso, la razza } \\
\text { Prof IT: Esattamente, sono tutto, sono tutti uguali (pequena pausa) R! } \\
\text { (R demora para entender o que a professora queria, olha para ela e M mostra para ele a } \\
\text { parte que ele deveria ler) }\end{array}$ \\
\hline $42: 56-47: 52$ & $\begin{array}{l}\text { (R lê) } \\
\text { Le bambine e i bambini hanno diritto all'affetto } \\
\text { (M levanta a mão para falar) } \\
\text { Prof IT: No! Adesso M aspetta un po', Ra! hanno diritto all'affetto (Percebeu que só M } \\
\text { estava participando e resolveu dar oportunidade a outros também) } \\
\text { Ra: È affetto, attenzione dei genitori } \\
\text { Prof IT: E se la persona, se i genitori sono già morti? Nessuno? Deve dare affetto a questa } \\
\text { persona? } \\
\text { (M levanta a mão e se agita na cadeira para responder, a Prof IT faz um gesto com a } \\
\text { mão para ela esperar e diz) } \\
\text { Prof IT: Aspetta! (E vira o rosto para o outro lado) } \\
\text { S: Amico } \\
\text { Prof IT: Chi? L'amico? L che ne dici? } \\
\text { L: Il nonno, la zia } \\
\text { Ra: I familiari } \\
\text { Prof IT: La scuola non è anche un posto dove un bambino può sentire l'affetto delle persone? } \\
\text { S: Si pensa } \\
\text { Prof IT: Ah S, tu sei triste oggi! Vuoi più attenzione, vero? Ti conosco } \\
\text { (M levanta a mão) } \\
\text { Prof IT: Oi } \\
\text { M: Maestra, questo diritto vuol dire che i genitori devono avere amore per i propri figli } \\
\text { Prof IT: Ma se non hanno i genitori, M? } \\
\text { (Fica fica em silêncio pensando) } \\
\text { Prof IT: Quando se dice.. non dice... non c'è scritto che solo i genitori devono essere } \\
\text { affettuosi, L } \\
\text { M: Anche } \\
\text { Prof IT: No, aspetta, M, dobbiamo sentire gli altri } \\
\text { L: Posso andare in bagno? } \\
\text { Prof IT: No, adesso no. L! Oh L no, è F! } \\
\text { F: Che? } \\
\text { Prof IT: La tua opinione } \\
\text { F: Do que? } \\
\text { (Classe ri) } \\
\text { Prof IT: Do que? } \\
\text { F: Dos homens } \\
\text { S: Homem- aranha } \\
\text { (Classe ri) }\end{array}$ \\
\hline
\end{tabular}




\begin{tabular}{|c|c|}
\hline & 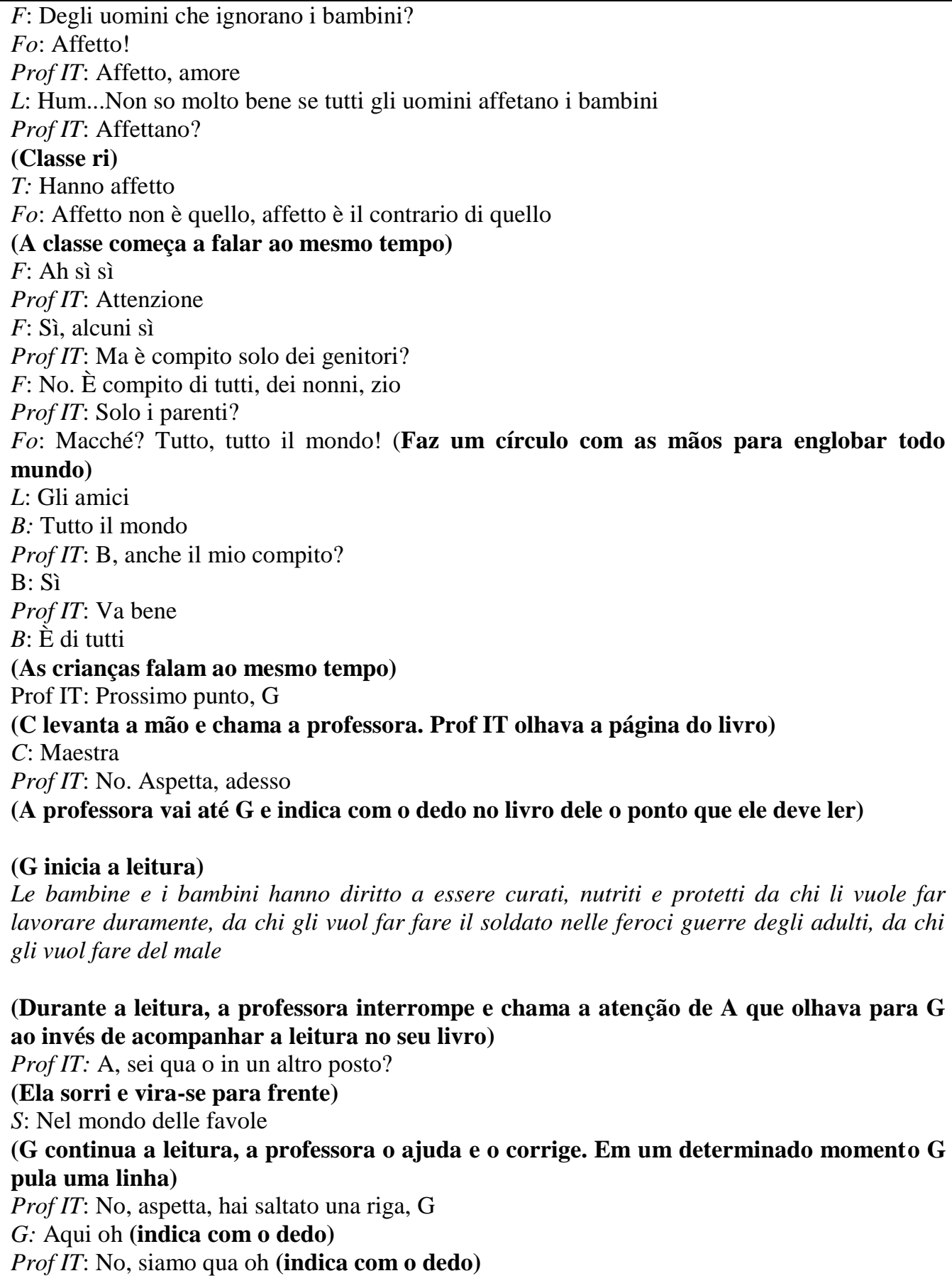 \\
\hline $47: 52-51: 40$ & $\begin{array}{l}\text { Prof IT: Che ne pensate, cosa ne pensate? } \\
\text { (M levanta a mão e Prof IT diz) } \\
\text { Prof IT: Un' altra persona } \\
\text { M: No! } \\
\text { L: Posso? } \\
\text { Prof IT: L. Non è leggere è fare un commento } \\
\text { L: Ah, no (sorri e balança a cabeça de forma negativa) } \\
\text { ( M levanta a mão) } \\
\text { Prof IT: Vai M } \\
\text { M: Maestra questo diritto vuol dire che le persone che non si trovano bene devono essere } \\
\text { curati... devono essere.. devono prendere delle cose per... (faz um gesto com os braços }\end{array}$ \\
\hline
\end{tabular}




\begin{tabular}{|c|c|}
\hline & 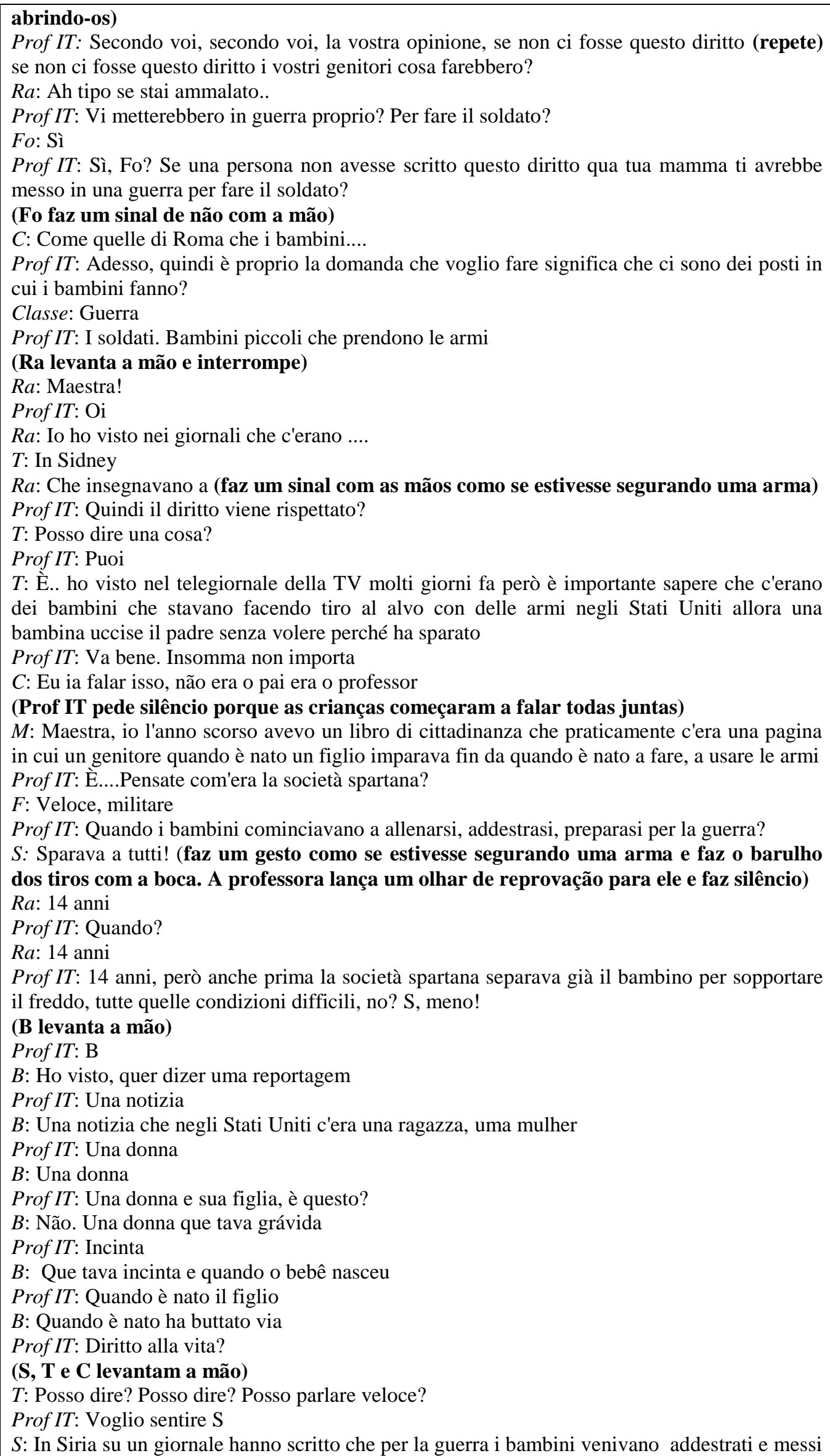 \\
\hline
\end{tabular}




\begin{tabular}{|c|c|}
\hline & $\begin{array}{l}\text { in prima linea } \\
\text { Prof IT: Va bene, ok. }\end{array}$ \\
\hline 51:40- 58:05 & 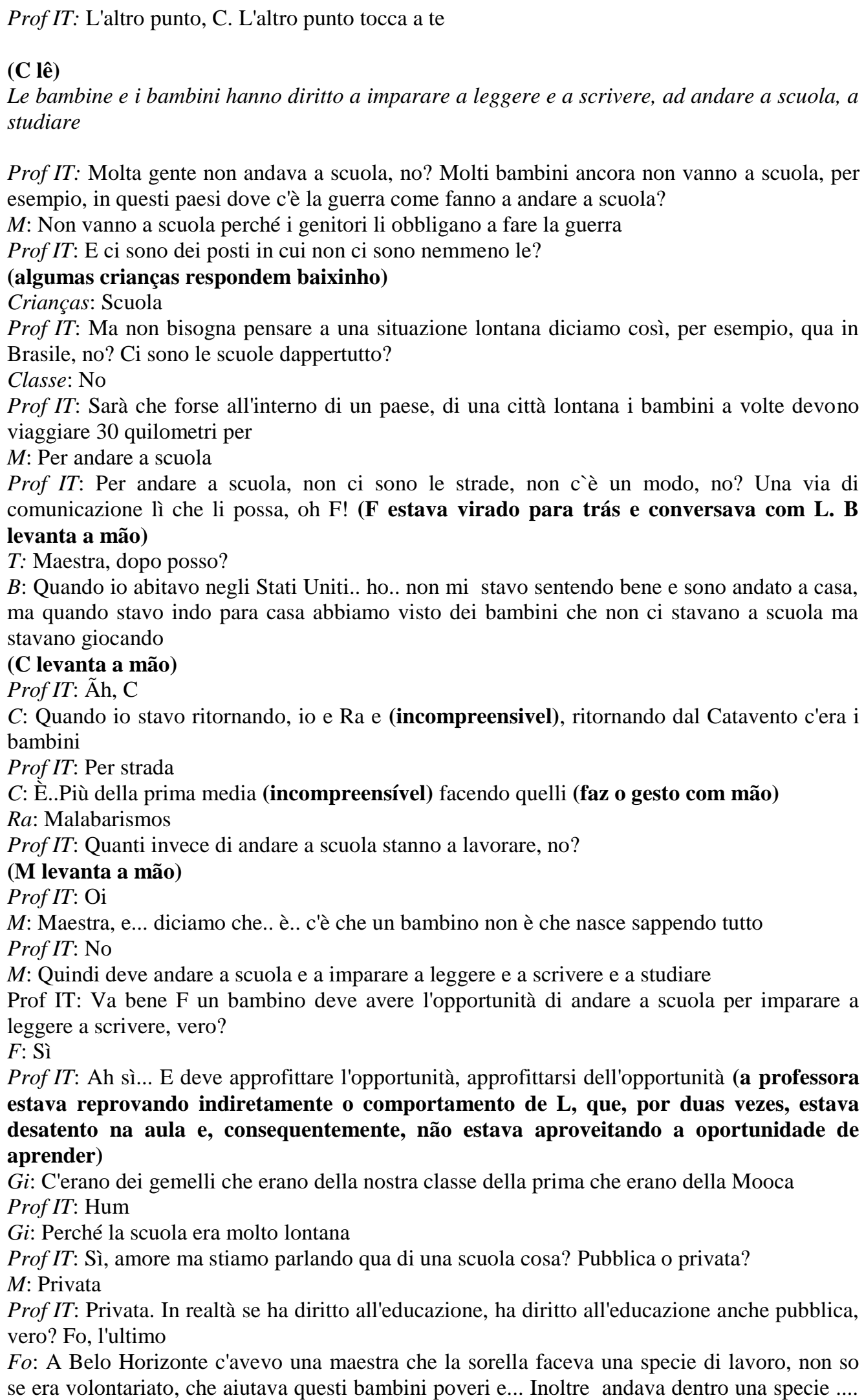 \\
\hline
\end{tabular}




\begin{tabular}{|c|c|}
\hline & $\begin{array}{l}\text { una sorella a vedere i bambini, se li matratavano e allora è entrata dentro le case e i bambini } \\
\text { tutto (fez um gesto com as mãos).. e i bambini così sopra la caca } \\
\text { Prof IT: Triste, no? Quindi questo diritto, questo bambino non vive in una situazione di } \\
\text { sicurezza, di rispetto, non ha quello da mangiare, non ha protezione } \\
\text { Fo: Invece anche un amico di mio padre che ha moglie e non può avere figli, hanno adottato } \\
\text { due bambini e sono fratelli, però loro non sono soltanto due, erano tipo cinque fratelli, però gli } \\
\text { altri erano andati in giro e la madre era morta dentro, perché avevano incendiato la casa si è } \\
\text { buttata dentro, e il padre stava in galera. } \\
\text { Prof IT: Nossa. } \\
\text { Fo: Lo so } \\
\text { (C levanta a mão) } \\
\text { Prof IT: C! E L farà l'ultimo poi facciamo l'ultimo diritto } \\
T \text { : Dopo posso? Perché devo dire una cosa importante } \\
\text { Prof IT: Ok } \\
\text { A: Dopo io posso leggere l'ultimo diritto? } \\
\text { Prof IT: Puoi partecipare anche, A (tom de reprovação porque a aluna não participa das } \\
\text { discussões, está sempre dispersa) } \\
\text { C: Quando andavo al shopping.. per strada, c'è sempre bambini } \\
\text { Prof IT: Che chiedono delle cose? } \\
\text { C: Che chiedono delle cose. } \\
\text { Prof IT: L, volevi dire qualcosa, no, T } \\
\text { L: C'è una cosa che Gi non si è ricordato di dire che questi gemelli hanno anche scelto la } \\
\text { scuola, sono usciti dalla scuola non solo perché abitavano lontano ma anche per il prezzo } \\
\text { (incompreensível) } \\
\text { Prof IT: Che è anche un'altra cosa.... } \\
T: \text { Io non lo facevo per esempio } \\
\text { Prof IT: Ok T cosa volevi dire? } \\
\text { T: È.. che io una volta stavo è.. se mi ricordo quando eravamo al Catavento, stavamo } \\
\text { camminando allora io ero un po' indietro lì con F e io avevo visto vicino a una fontana, io e F } \\
\text { avevamo visto vicino alla fontana la madre e i tre figli il padre non so dov'era, erano sopra una } \\
\text { coperta, non avevano una casa, non avevano soldi, non avevano niente } \\
\text { Prof IT: L'ultimo diritto (a professora ignora mais uma vez o comentário). È vai, F, chi } \\
\text { deve leggere? F e A, vero? } \\
L: \text { Anche io non ho ancora } \\
B: \text { Anche io non ho ancora } \\
\text { Prof IT: Ma stiamo seguendo quall'ordine, amore? Vai L e F }\end{array}$ \\
\hline $58: 05-60: 00$ & $\begin{array}{l}\text { (F lê) } \\
\text { Le bambine e i bambini hanno diritto al riposo e a giocare } \\
\text { Prof IT: Âh l'ultimo } \\
\text { (L lê) } \\
\text { Le bambine e i bambini hanno diritto a vivere in città amiche } \\
\text { Prof IT: Cos'è vivere in città amiche? } \\
\text { Fo: Che non devono essere deportati } \\
\text { M: Maestra tipo.. è... quando conoscono una città (toca o sinal de término da aula) devono } \\
\text { viver lì... c'è...quando conosci bene una città, non vuoi separare, tu vuoi rimanere lì } \\
\text { Prof IT: Bambini! Il titolo della poesia era La pace verrà. Voi mi avete già citato degli } \\
\text { elementi che ci fanno capire che ancora oggi dopo questa conferenza, dopo i diritti, dopo } \\
\text { l'elaborazione di questi diritti ancora oggi questi diritti non vengono rispettati da? } \\
\text { Classe: Le persone } \\
\text { Prof IT: E la pace verrà soltanto se } \\
\text { M: Se tutte le persone rispettino questi diritti } \\
\text { Prof IT: Bravissima. Se le persone riescono a capire l'importanza di questi diritti, perché poi } \\
\text { questi bambini che non hanno i diritti rispettati un giorno cresceranno e rispetteranno l'altro? }\end{array}$ \\
\hline
\end{tabular}


$M$ : No.

Prof IT: Sarà più difficile, vero? Ok bambini! Aspettate un po' perché vi devo chiedere di fare una cosa.

(Prof IT entrega os questionários da minha pesquisa para as crianças preencherem) 


\section{ANEXO E - QUESTIONÁRIO UTILIZADO PARA A COLETA DE DADOS}

Nome: Idade:

Cidade de nascimento:

1-) Qual é a nacionalidade dos seus pais e avós?

\begin{tabular}{|l|l|}
\hline Pai: & Mãe: \\
\hline Avô paterno: & Avô materno: \\
\hline Avó paterna: & Avó materna: \\
\hline
\end{tabular}

2-) Que línguas se falam na sua casa?

3-) Você sempre morou em São Paulo?

4-) Se você já morou em outras cidades, quais foram? E por quanto tempo?

5-) Há quantos anos frequenta a Scuola Italiana?

6-) Você já frequentou alguma outra escola antes?

7-) Fora da escola, você fala qual língua com seus amigos? 


\section{ANEXO F- TERMO DE CONSENTIMENTO LIVRE E ESCLARECIDO}

$\mathrm{Eu}$, portador da cédula de identidade $\mathrm{n}^{\mathrm{O}} \longrightarrow$, responsável pelo aluno (a) autorizo o registro de sua participação na pesquisa de campo desenvolvida por França H. A. Berton - mestranda em Língua Italiana pelo Departamento de Línguas Modernas da Faculdade de Filosofia, Letras e Ciências Humanas da Universidade de São Paulo (DLM-FFLCH-USP) e orientanda da $\operatorname{Prof}^{\mathrm{a}} \operatorname{Dr}^{\mathrm{a}}$ Elisabetta Santoro -, a ser realizada durante as aulas de língua italiana e língua portuguesa, na Scuola Italiana Eugenio Montale, no $2^{\circ}$ semestre de 2015 .

A pesquisa tem por objetivo coletar dados sobre ensino de línguas e os instrumentos utilizados serão gravações das aulas em vídeo e em áudio.

Estou ciente de que tenho liberdade de retirar o meu consentimento em qualquer fase da pesquisa sem penalização alguma. A qualquer momento, posso buscar mais esclarecimentos, até mesmo relativos à metodologia do trabalho.

Declaro saber que as informações obtidas só podem ser usadas para fins científicos, de acordo com a ética na pesquisa, e que essa participação não prevê nenhum tipo de pagamento.

Declaro saber também que, caso seja necessário projetar a gravação em vídeo em contexto científico e acadêmico, a imagem da face do participante da pesquisa será preservada por borrão digital.

( ) Autorizo a utilização de vídeo, áudio e transcrições.

( ) Autorizo a utilização de áudio e transcrições.

( ) Autorizo a utilização de transcrições.

São Paulo, de de 2015.

Muito obrigada pela preciosa colaboração com esta pesquisa!

França Berton

e-mail:fran_berton@hotmail.com 